\title{
COMPORTAMENTO PROCESSUAL CONTRADITÓRIO
}

\author{
Dissertação de Mestrado \\ Orientador: Professor Titular Dr. José Roberto dos Santos Bedaque
}

UNIVERSIDADE DE SÃO PAULO

FACULDADE DE DIREITO

SÃO PAULO-SP

2014 


\title{
COMPORTAMENTO PROCESSUAL CONTRADITÓRIO
}

\begin{abstract}
Dissertação apresentada à Banca Examinadora do Programa de Pós-Graduação em Direito, da Faculdade de Direito da Universidade de São Paulo, como exigência parcial para obtenção do título de Mestre em Direito, na área de concentração Direito Processual, sob a orientação do Professor Titular Dr. José Roberto dos Santos Bedaque.
\end{abstract}

UNIVERSIDADE DE SÃO PAULO

FACULDADE DE DIREITO

SÃO PAULO-SP 
Autorizo a reprodução e divulgação total ou parcial deste trabalho, por qualquer meio convencional ou eletrônico, para fins de estudo e pesquisa, desde que citada a fonte.

Serviço de Biblioteca e Documentação

Faculdade de Direito da Universidade de São Paulo

\section{T835c Comportamento processual contraditório /}

Larissa Gaspar Tunala . -- São Paulo: USP / Faculdade de Direito, 2014.

$281 \mathrm{f}$.

Orientador: Prof. Dr. José Roberto dos Santos Bedaque

Dissertação (Mestrado), Universidade de São Paulo, USP, Programa de Pós-Graduação em Direito, Direito Processual Civil, 2014.

1. Processo civil. 2. Boa-fé. 3. Cooperação.

4. Abuso do direito. 5. Decisão judicial. I. Bedaque, José Roberto dos Santos. II. Título. 


\section{AGRADECIMENTOS}

Os que já passaram por isso certamente concordarão, e, para os que ainda não passaram, aqui vai o alerta desde logo: o aparente curto caminho de uma pesquisa de três anos é, na verdade, uma longa jornada. E, nessa minha caminhada, contei com a ajuda indispensável de pessoas essenciais na minha vida, as quais dedico os meus sinceros agradecimentos.

Em primeiro lugar, à minha mãe, que mesmo há algum tempo já não mais pertencente a esse mundo, é minha verdadeira fonte de inspiração. Sem ela, não saberia admirar da maneira adequada os estudos, a atividade de magistério, o potencial das palavras. Agradeço todos os dias a Deus por ter me dado o privilégio do convívio não tão grande quanto gostaria, mas o suficiente para eu ter em mente e no coração um eterno exemplo de ser humano.

A meu pai, igualmente exemplar, e que ensina diariamente a não me esquecer dos valores do trabalho duro, da persistência, e da disciplina. Obrigada por nunca me deixar desviar do caminho, obrigada por ser o meu porto seguro.

Aos meus queridos irmãos Letícia, Roberto e principalmente Eduardo, que tem a paciência de debater comigo os mais diversos assuntos jurídicos. Vocês são uma benção em minha vida.

Mais especificamente no que diz respeito ao resultado desta pesquisa, minha imensa gratidão ao Professor José Roberto dos Santos Bedaque, meu orientador, o responsável por me fazer eutusiasmar pelo processo logo na graduação, e sem o qual esse sonho não poderia ter se concretizado. Obrigada por me fazer ver para além do que simplesmente está escrito na lei processual.

O sonho, porém, sequer existiria se não fosse a minha querida amiga e Professora Lia Carolina Batista Cintra. Ela foi a verdadeira responsável por esse projeto, pois sem ela, eu não seria capaz de imaginar que isso tudo seria possível, muito menos de concretizá-lo. Espero um dia poder retribuir tudo que você fez por mim. 
Igualmente essencial foi o meu chefe e amigo Hugo Crepaldi Neto. Suas palavras de incentivo contribuíram muito para o meu ingresso na vida acadêmica. Minha mãe sempre dizia que o verdadeiro líder é aquele que não quer brilhar sozinho, mas que sabe dar espaço para ser rodeado de outras estrelas. Não consigo ilustrar de maneira melhor a personalidade generosa do Dr. Hugo, que não tem medo de estrelas, e, pelo contrário, incentiva-as a brilhar. Obrigada por enxergar em mim um brilho que nem eu mesma sabia existir.

Ao Bruno, meu amor, pelo apoio emocional (e jurídico!) de todos os dias. Já não imagino o fim do meu dia sem o seu abraço indescritivelmente confortante, e não imagino como chegaria ao fim deste trabalho sem você.

Ao Professor Claudio Bueno Godoy, pelas imprescindíveis ponderações de direito material, e ao Professor Heitor Vitor Mendonça Sica, pelos conselhos essenciais, pela atenção ímpar, e por ter conseguido tempo para me ajudar mesmo já tendo tantos alunos sob a sua dedicada orientação.

O mestrado nos traz mais do que novos saberes, traz novas amizades também. Exemplos disso são Gabriela Kazue, João Eberhardt Francisco, José Eugênio do Amaral Souza Neto, Elie Elid, Adriano Camargo Gomes, Paulo Neder, Eduardo Motta Junior e Vilson Bertelli. Incluo aqui, ainda, os companheiros de processo antes mesmo do mestrado, Felipe Amaral Matos e Gabriel Riguetti. Obrigada por tudo.

Aos meus queridos amigos de convivência diária no trabalho, Ana Lúcia Sayuri Watanabe, Mariana Elisa Lourenço de Souza, Alfredo Augusto Freire Fonseca e Claudia Abe Fernandes, por terem me aguentado falar tanto de condutas contraditórias, e por terem enorme paciência comigo neste ano de 2014.

Agradeço imensamente às minhas companheiras da graduação inteira e, agora, companheiras de vida, Raquel de Mattos Pimenta, Mariana Martins Nunes, Rafaela Junqueira de Oliveira, Yasmin Oliveira Mercadante Pestana, Mariana Akita de Araújo, e Regina Stela Vieira. Obrigada por todo o companheirismo e incentivo, em cada aula, trabalho, em cada decisão da minha vida, inclusive na de fazer mestrado.

Obrigada à Maria Olívia Pessoni Junqueira, pelo companheirismo, por compartilhar das mesmíssimas angústias neste ano de 2014. Obrigada ao sempre amigo Gabriel Verea, pelo auxílio com a língua estrangeira. 


\section{RESUMO}

Larissa Gaspar Tunala. Comportamento processual contraditório. 281 folhas. Mestrado Faculdade de Direito, Universidade de São Paulo, São Paulo, 2014.

A teoria nemo potest venire contra factum proprium visa a coibir condutas contraditórias que rompam as legítimas expectativas geradas em terceiros. Não se trata de vedar qualquer contradição, mas apenas aquelas de que decorra ruptura da confiança gerada por comportamento anterior. O instituto é objeto de estudos aprofundados no âmbito do Direito Civil, mas na seara processual poucos trabalhos foram desenvolvidos. Não obstante, a experiência jurisprudencial revela a importância de sua aplicabilidade ao Processo Civil, porque os comportamentos processuais também são capazes de gerar expectativas que merecem ser protegidas quando frustradas pela adoção de condutas processuais contraditórias. Ao Processo Civil se aplicam os princípios da boa-fé objetiva e da cooperação, exigindo de todos os sujeitos processuais condutas pautadas na observância desses dois postulados. Uma vez rompida essa exigência, por meio da adoção de comportamentos processuais contraditórios, surge espaço para a incidência do venire, cuja finalidade reside em obstar os efeitos da contradição, bem como incentivar a reflexão prévia dos sujeitos processuais sobre as possíveis consequências de seus atos. Destaca-se como finalidade do presente trabalho delimitar as bases jurídicas para aplicação do instituto ao processo, definir seus principais requisitos e consequências jurídicas.

Palavras-chave: venire contra factum proprium; condutas processuais contraditórias; confiança; boa-fé objetiva processual; cooperação; preclusão. 


\begin{abstract}
Larissa Gaspar Tunala. Contradictory conducts in Civil Procedure. 281 pages. Master Faculty of Law, University of São Paulo, São Paulo, 2014.

The nemo potest venire contra factum proprium theory aims to stop contradictory conducts that break legitimate expectations entrusted by third parties. It is not about avoiding any contradiction, but only those which violate the trust originated by previous behavior. The institute was object of further investigation in the Civil Law field of research, however in the Civil Procedure Law there are only few studies about it. Nevertheless, jurisprudence experience reveals the importance of its applicability in Civil Procedure, once procedural conducts also are able to create expectations that deserve to be preserved when frustrated by contradictory behavior. The good-faith and cooperation principles are applied to Civil Procedure, demanding that all parties involved act in accordance with those principles. Once the parties involved take contradictory conducts ignoring this demand, the nemo potest venire contra factum proprium can be invoked in order to withhold contradictory effects, and also to stimulate previous thoughts, avoiding contradictory conducts. This essay proposes to set legal basis to apply the nemo postet venire contra factum proprium theory in the Civil Procedure disputes, and also to define its main structures and legal consequences.
\end{abstract}

Key-words: venire contra factum proprium; contradictory civil procedure conducts; trust; procedural good-faith; cooperation; preclusion. 


\section{SUMÁRIO}

1. INTRODUÇÃO ..........................................................................................................................12

2. ANÁliSE PRELIMINAR DA JURISPRUDÊNCIA .................................................................17

2.1. Fenômeno quantitativamente expressivo .............................................................. 17

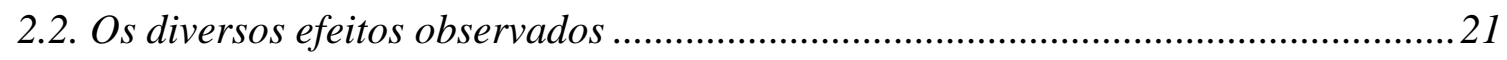

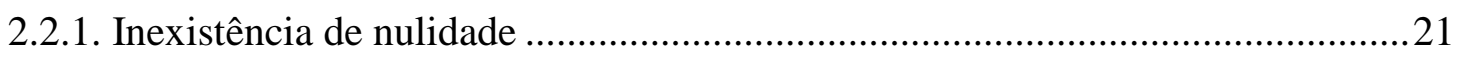

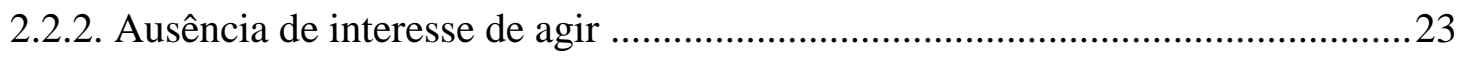

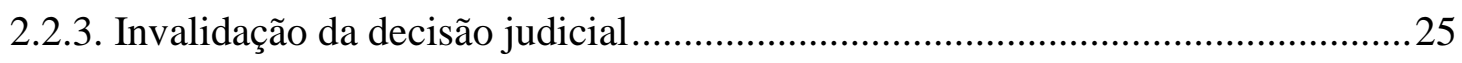

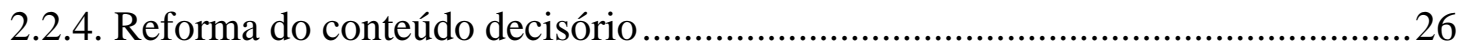

2.2.5. Desconsideração da alegação (ou inadmissibilidade do segundo ato da parte) .27

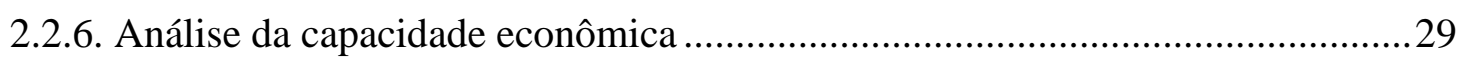

2.2.7. Relevância do venire processual para a apreciação do mérito ...........................29

2.2.8. Perda da situação jurídica processual pela demora em exercê-la........................ 30

2.3. Os diferentes sujeitos envolvidos na vedação de comportamentos processuais

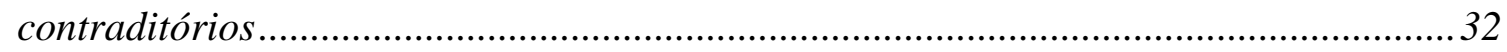

2.4. Os efeitos transcendem as barreiras endoprocessuais ............................................. 32

2.5. Sintese conclusiva da análise jurisprudencial ........................................................ 33

3. A VEDAÇÃo de Comportamentos Contraditórios no Direito Civil.....................35

3.1. Conceito e pressupostos para a aplicação da teoria ................................................. 35

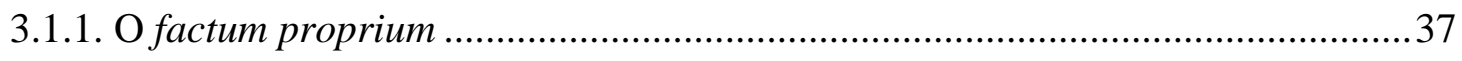

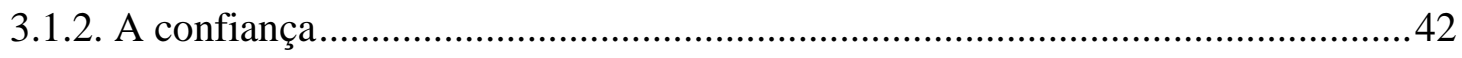

3.1.3. O comportamento contraditório e o dano .......................................................... 45

3.1.4. Observações finais: sujeitos ativo e passivo da contradição, não cumulatividade

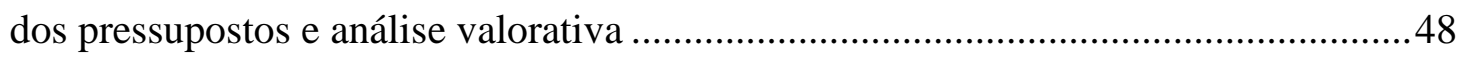

3.2. Base jurídica no ordenamento brasileiro .............................................................50

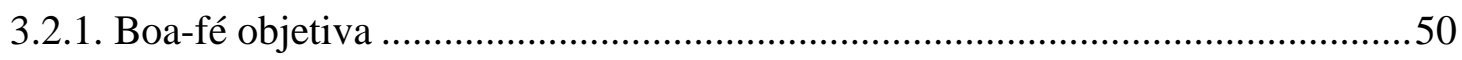

3.2.1.1. Boa-fé objetiva como princípio jurídico e como técnica de cláusula geral 51

3.2.1.2. Boa-fé objetiva $x$ boa-fé subjetiva ..........................................................56

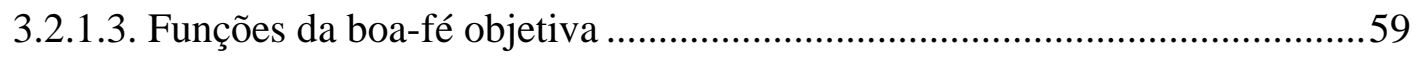


3.2.1.4. Boa-fé objetiva e venire 60

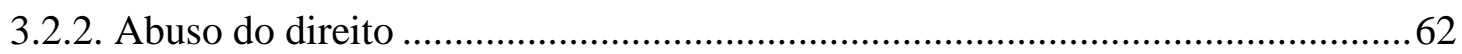

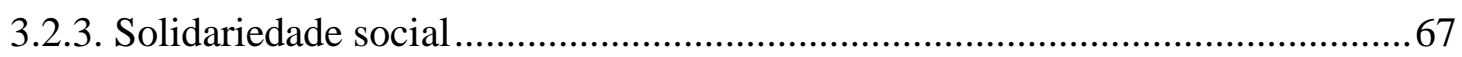

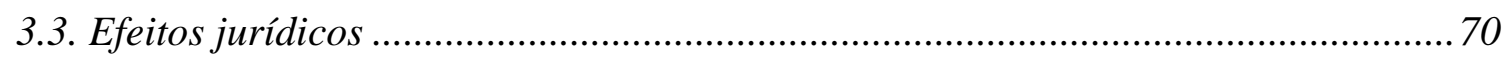

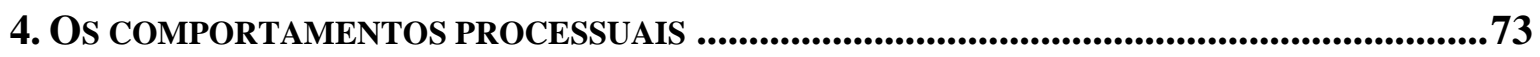

4.1. Situações jurídicas processuais das partes................................................................. 74

4.1.1. Situações processuais ativas: faculdades e poderes........................................... 74

4.1.2. Situações processuais passivas: deveres, ônus e sujeição ................................. 76

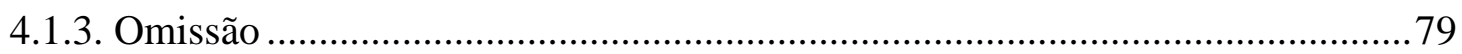

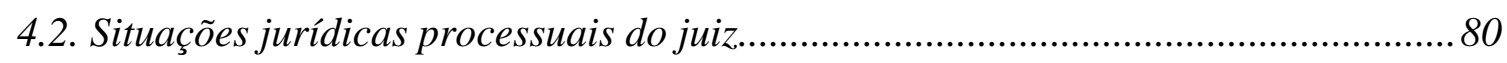

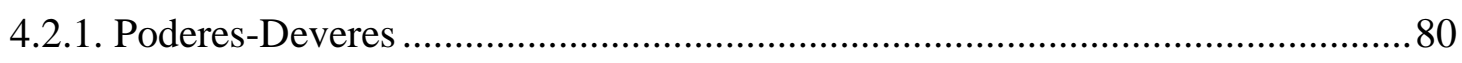

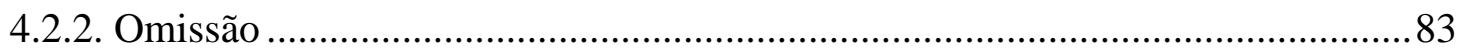

4.3. Consequência da inobservância da forma prevista em lei para as situações jurídicas

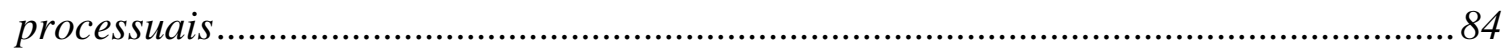

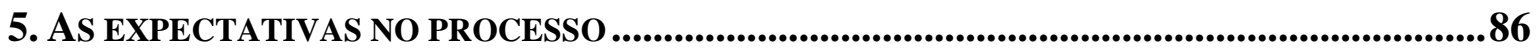

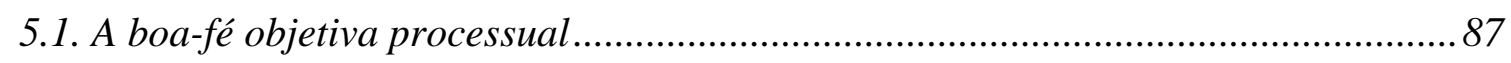

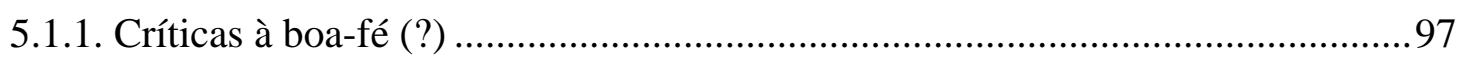

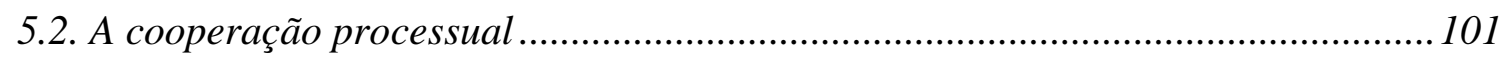

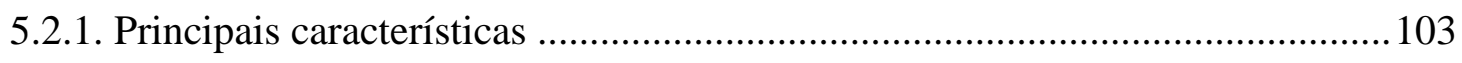

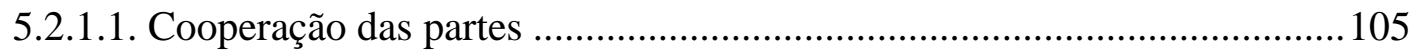

5.2.1.2. Cooperação do órgão julgador ................................................................ 108

5.2.1.3. Eficácia imediata do modelo cooperativo................................................ 110

5.2.2. Nova divisão do trabalho aplicável ao ordenamento brasileiro.........................113

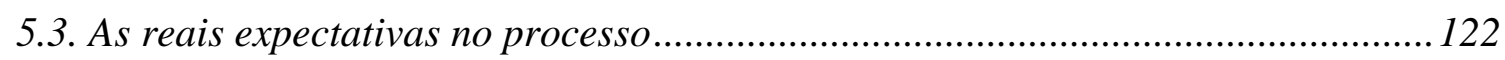

\section{COMPORTAMENTO PROCESSUAL CONTRADITÓRIO: VENIRE EM CONFRONTO COM}

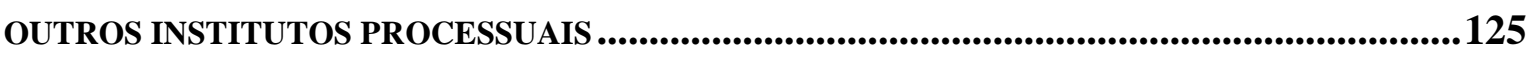

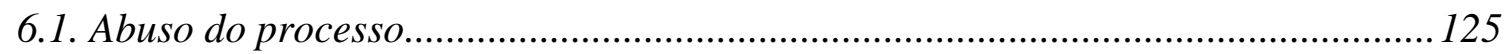

6.1.1. Venire: abuso do processo pelo rompimento da boa-fé....................................133

6.2. Litigância de má fé, ilícito processual, improbilidade e atos atentatórios à

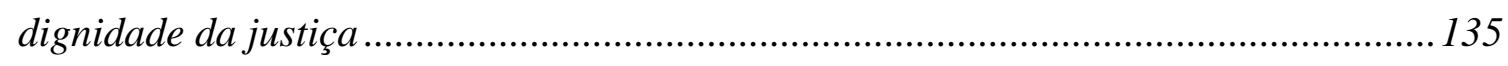

6.3. Valoração judicial da conduta das partes .......................................................... 141

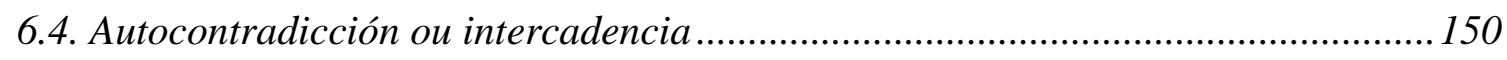

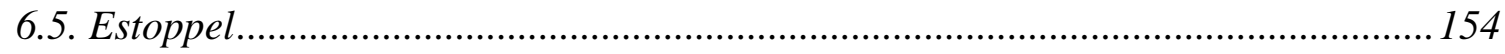

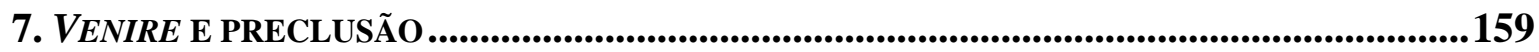




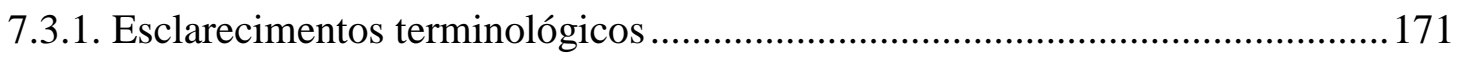

7.3.2. O conceito de preclusão para o juiz............................................................... 173

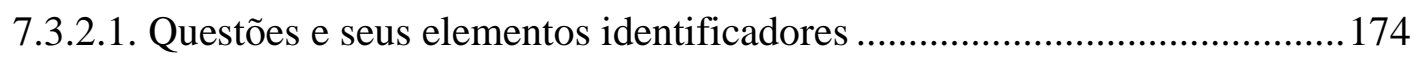

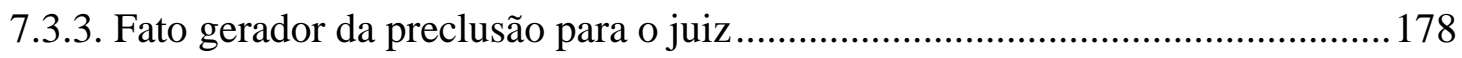

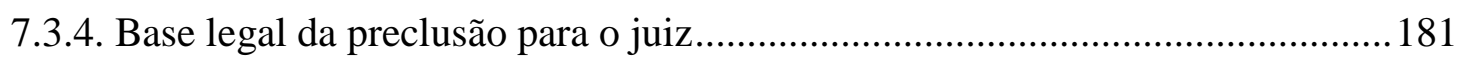

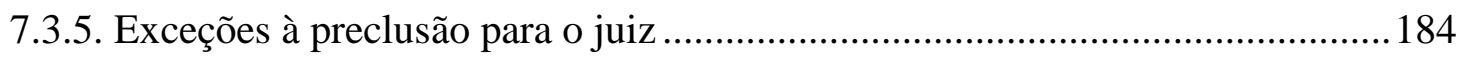

7.3.6. Ausência de decisões implícitas e de preclusão sobre o não-decidido..............190

7.4. Diferenciações entre preclusão e venire ................................................................. 193

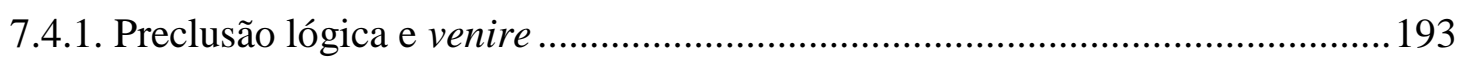

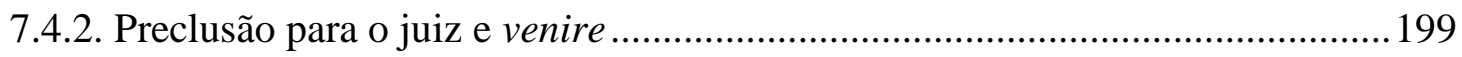

7.4.2.1. Vedação de comportamentos contraditórios e exceções à preclusão para o

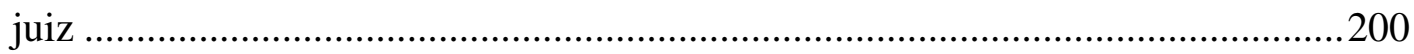

7.4.2.2. Contradição no enfrentamento de questões não idênticas ........................201

7.4.2.3. Vedação de comportamentos contraditórios e omissões conclusivas........202

7.4.2.4. Vedação de contradições praticadas fora da mesma sede processual:

limitação à análise micro da função jurisdicional................................................207

7.4.3. Análise sobre preclusão, venire e um novo sistema de estabilidades................210

8. APLICAÇÃO DO VENIRE AO PROCESSO ...................................................................................215

8.1. Conceito e pressuposto fundamental: análise valorativa objetiva ........................216

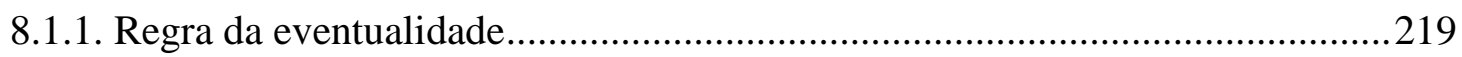

8.2. Situações jurídicas processuais: os comportamentos contraditórios......................222

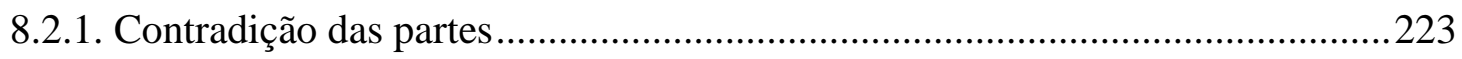

8.2.1.1. Contradição entre comportamentos e sede processual .............................224

8.2.1.2. Contradição e omissão conclusiva ..........................................................229

8.2.1.3. Os sujeitos das situações jurídicas em contradição: remetentes e

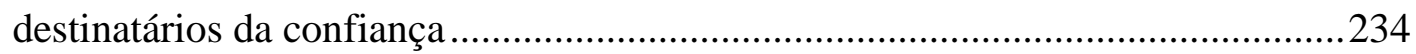

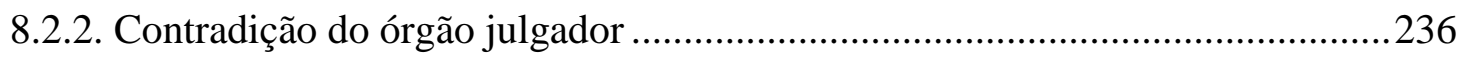

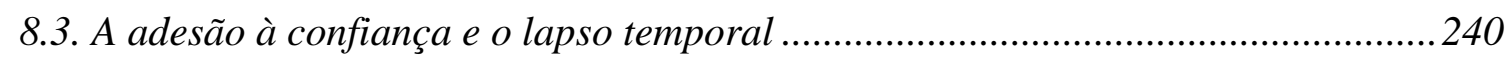

8.4. Subsidiariedade e aplicação de ofício ....................................................................243

8.5. Consequências da vedação de comportamentos processuais contraditórios..........244 
8.5.1. Reequilíbrio da confiança: a não produção de efeitos do comportamento contraditório

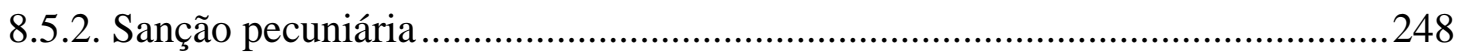

8.5.3. Valoração da conduta contraditória: a presunção desfavorável .......................250

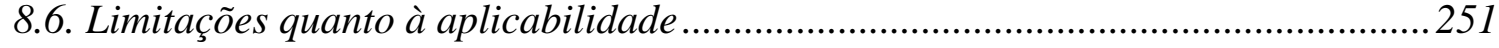

8.7. Principal contribuição: incentivo ao diálogo pelo necessário alinhamento de expectativas no curso de toda relação jurídica processual ...........................................256

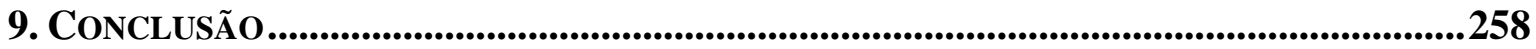

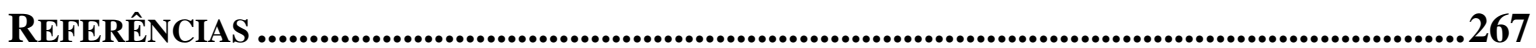




\section{INTRODUÇÃO}

O objetivo desta Dissertação de Mestrado consiste em estudar as consequências jurídicas da adoção de comportamentos processuais contraditórios, traduzindo para o campo processual a ideia nemo potest venire contra factum proprium.

Essa figura foi compreendida com maior profundidade no âmbito do Direito Civil, seara jurídica que definiu como sendo a finalidade primordial do venire ${ }^{1}$ a proteção da confiança originada a partir da adoção de determinado comportamento, e que venha a ser rompida pelo exercício de conduta posterior, nitidamente contraditória à primeira. Não se trata de instituto destinado a vedar a contradição por si só - que, por vezes, é benéfica e necessária à evolução da $\operatorname{sociedade}^{2}$-, mas a obstar a produção de efeitos do comportamento que, por ser contraditório à postura anteriormente assumida, fira as expectativas geradas em terceiros.

Constataram os civilistas que o venire contra factum proprium é figura parcelar da boa-fé objetiva, sendo essa a sua principal base jurídica ${ }^{3}$. Assim, uma vez rompido o dever de se pautar na lealdade no transcorrer das interações sociais, por meio do exercício de condutas contraditórias, surge espaço para incidência do venire.

Essa teoria tem grande aplicabilidade, no âmbito do Direito Civil, em contextos negociais, nos quais há uma expectativa de cooperação entre as partes para que seja possível a formação de um acordo de vontades quanto à conclusão do negócio. Todavia, a

\footnotetext{
${ }^{1}$ Por uma questão de praticidade e fluidez do texto, utilizaremos a expressão "venire" como sinônimo de todo o fenômeno da vedação de comportamentos contraditórios.

${ }^{2}$ Nesse sentido, JUdITH MARTINS-COSTA afirma que "evidentemente, a contraditoriedade, em si mesma, não é sancionada. A vida é tecida por imprevistos, a surpresa pode ser um dom, viver é adaptar-se ao inesperado no que este tem de vantagens e desvantagens: só os robôs (mecânicos ou humanos...) tudo têm programado de forma inflexível. Por isso mesmo, nem toda conduta contraditória constitui requisito suficiente para invocação do princípio, nem há um dever de coerência absoluta que possa ser apreciado in abstracto". (A ilicitude derivada do exercício contraditório de um direito: o renascer do venire contra factum proprium, $\mathrm{p}$. 120).

${ }^{3}$ A boa-fé, sem dúvida, é apontada como a principal base jurídica para a incidência do venire, mas não é a única fonte destacada pela doutrina civil, sendo comum também a classificação do venire como uma espécie de abuso do direito (e, portanto, embasado no art. 187 do Código Civil), bem como fundamentado no princípio constitucional da solidariedade social (art. $3^{\circ}$ da Constituição Federal). Sobre as bases jurídicas do venire no nosso ordenamento, $c f$. ANDERSON SCHREIBER, A proibição de comportamento contraditório: tutela da confiança e venire contra factum proprium, pp. 69-114. O tema será aprofundado no Capítulo 3 infra.
} 
aplicação do instituto se expandiu, passando a ser admitida também em casos concernentes a ramos do Direito Público, dentre os quais, o Processo Civil ${ }^{4}$.

O primeiro capítulo evidencia essa realidade: a análise da jurisprudência nacional revela que o venire já vem sendo aplicado no âmbito processual de maneira quantitativamente expressiva, e nos mais variados contextos processuais. Todavia, essa mesma análise demonstra a carência teórica sobre o tema ${ }^{5}$ : muitas vezes a invocação do venire é feita sem qualquer justificativa mais aprofundada, e, como se verá, sua aplicação era dispensável diante da existência de outros institutos que solucionariam a problemática concreta.

Diante dessa realidade, justifica-se a escolha do tema. É necessário estabelecer as premissas teóricas que justifiquem a vedação a comportamentos contraditórios em âmbito processual. Isso pressupõe, primeiramente, conhecer como o nemo potest venire contra factum proprium foi estudado pelo Direito Civil, ou seja, seus principais pressupostos, as bases jurídicas que fundamentam sua aplicabilidade e quais os efeitos decorrentes de sua observância.

Em seguida, o foco será analisar a manifestação do fenômeno em âmbito processual, revelando-se as peculiaridades com relação a outras searas, principalmente de modo a identificar e compreender as possíveis consequências da adoção de comportamentos processuais contraditórios. E, para isso, compreendamos desde já que, assim como no Direito Civil, há valores a serem preservados no Processo, que, uma vez rompidos pela adoção de condutas processuais contraditórias, dão espaço à incidência do venire.

Entretanto, antes mesmo da análise das expectativas que norteiam o processo e que devem ser preservadas, para que seja possível enfrentar o tema da incidência do venire em âmbito processual, é preciso compreender quais os possíveis comportamentos a serem

\footnotetext{
${ }^{4}$ JUDITH MARTINS-COSTA apresenta uma coletânea de casos de aplicação do venire nas mais diversas áreas do Direito: "Foram contempladas situações de contradição desleal no Direito de Família, no Direito Contratual, no Direito Societário, no Direito Tributário, no Direito Administrativo e no Direito Processual". (A ilicitude derivada do exercício contraditório de um direito: o renascer do venire contra factum proprium, pp. 116-122).

A aplicação pela jurisprudência sem um respaldo teórico consistente sobre o venire é também uma realidade na Argentina: "El caso es que, salvo excepciones honrosas, hasta aquí la doctrina se ha aplicado en Argentina sin mayor precisión y ha servido en ocasiones para hacer justicia y en otras, simplemente, para acallar al judiciable, sin entrar a analizar si se deban los presupuestos para la aplicación de la doctrina en el caso concreto y, en muchos casos, no concurriedo ellos." (MARCELO J. LÓPEZ MESA, La doctrina de los actos propios: esencia y requisitos de aplicación, p. 194). No mesmo sentido, JORGE PEYRANO, La doctrina de los propios actos en el ámbito del procedimiento civil, p. 224.
} 
adotados, ou seja, quais as situações jurídicas processuais postas à disposição dos sujeitos do processo e que, uma vez exercidas em contradição, podem configurar o venire.

Fundamental esclarecimento a ser feito em caráter introdutório, ainda quanto aos possíveis comportamentos processuais, a omissão é tida ao longo de todo o trabalho como um comportamento processual e que, nos casos em que responsável por gerar uma expectativa posteriormente rompida pelo exercício de situação jurídica contraditória, é capaz de configurar o venire. Esses casos são tratados por grande parte da doutrina civilista não como venire, e sim como suppressio, outra figura parcelar da boa-fé objetiva, mas, como será abordado com maior profundidade no Capítulo 3 infra, adotamos a corrente segundo a qual a suppressio nada mais é do que uma subespécie do venire ${ }^{6}$.

Estabelecidas as premissas quanto às situações jurídicas processuais e a possibilidade de contradição, surge a necessidade de analisar as expectativas que norteiam o processo, o que implica o estudo não só da incidência da boa-fé objetiva a ser observada sempre que existente uma relação jurídica processual, mas também do princípio da cooperação, cuja efetividade não está associada à ilusória ideia de que as partes cooperarão espontaneamente entre $\mathrm{si}^{7}$, mas sim relacionada à identificação de elementos legislativos que demandam sua observância, a fim de melhor serem atingidos os escopos do processo. E, como ferramenta à disposição dos sujeitos processuais para exigir a cooperação e o respeito à boa-fé objetiva, destaca-se a vedação de comportamentos contraditórios.

Esses princípios - boa-fé objetiva e cooperação - serão temas necessariamente enfrentados para viabilizar a análise das expectativas que norteiam os comportamentos processuais, de modo a estabelecer que tipo de proteção valorativa o venire visa a assegurar. Afinal, conforme já se afirmou, a finalidade do venire não é vedar qualquer tipo de contradição, mas apenas aquelas que afrontem expectativas geradas pela conduta inicialmente praticada, razão pela qual, para sua incidência, fundamental realizar frente ao caso concreto um juízo valorativo sobre as circunstâncias processuais e a confiança gerada.

A imprescindibilidade desse juízo valorativo merece ser destacada, pois, esquecendo-se disso, muitos autores relacionam o venire a situações em que sua aplicação é descabida, vez que realizada a partir de um procedimento lógico que independe de valoração. Isso se verifica inclusive em âmbito processual, como é o caso da constante

\footnotetext{
${ }^{6}$ ANDERSON SCHREIBER, A proibição de comportamento contraditório, p. 189.

${ }^{7}$ Como bem aponta MENEZES CORDEIRO, existe a "cultura da astúcia" (Litigância de má-fé, abuso do direito de ação e culpa "in agendo", p. 24), e esse aspecto fático não pode ser ignorado em desenvolvimentos teóricos como o presente, conforme se aprofundará adiante.
} 
equiparação que se faz entre o venire e a preclusão lógica ${ }^{8}$, o que, à luz dos conceitos a serem aqui desenvolvidos, pode ser mais bem explicado: é certo que os institutos possuem semelhanças, mas as diferenças identificadas impedem que sejam tratados como figuras absolutamente coincidentes.

Há outras figuras que, da mesma maneira, tem por finalidade coibir práticas processuais contrárias aos valores mencionados, como é o caso da litigância de má-fé, do abuso do processo e da improbidade. Isso sem mencionar os institutos provenientes de ordenamentos jurídicos estrangeiros, como o estoppel e a autocontradicción. Tais figuras serão analisadas a fim de se averiguar no que diferem, e no que coincidem com a vedação de comportamentos processuais contraditórios, estudo que será imprescindível para traçarmos as possíveis consequências da contradição no processo.

Finalmente, aproximando-se da conclusão, será feita uma retomada de todos os temas enfrentados, o que permitirá a fixação dos principais pressupostos da teoria da vedação a comportamentos contraditórios aplicada ao processo, suas bases jurídicas, hipóteses de incidência, e peculiaridades com relação ao direito material, buscando-se esclarecer as problemáticas apontadas no curso do trabalho e contribuir para a aplicação mais adequada do instituto em âmbito processual.

Isso tudo, porém, de modo a estudar apenas as consequências da adoção de comportamentos contraditórios no Processo Civil ${ }^{9}$. A contradição, uma vez observada no Processo Penal, merece estudo especializado, principalmente porque nesta seara há valores jurídicos que lhe são peculiares, comprometendo, assim, uma equiparação que acabaria por ser descompromissada. Em caráter exemplificativo, basta pensar que, sob a perspectiva do acusado, o princípio da presunção da inocência altera bastante as expectativas que possam

\footnotetext{
${ }^{8}$ Assim entendem FREDIE DIDIER JR. e PEDRo NoGUEIRA, pois afirmam que “a ideia de preclusão lógica é a tradução, no campo do direito processual, da regra nemo potest venire contra factum propirum" (Teoria dos fatos jurídicos processuais, pp. 98-99). No mesmo sentido, $c f$. DANIEL MitidiERO e LUIZ GUILHERME Marinoni, Propriedade industrial. Boa-fé objetiva. Proteção da confiança. Proibição do venire contra factum proprium no processo. Dever de não conhecer do recurso, p. 187.

${ }^{9}$ Em princípio, salvo o Processo Penal, não há impedimentos para aplicação do que será exposto neste trabalho a outras searas processuais nas quais o Processo Civil sirva de base subsidiária, tais como o processo trabalhista. Desde que não haja grandes diferenças valorativas no que se refere à análise do comportamento dos sujeitos processuais, ou seja, desde que as premissas utilizadas neste trabalho sirvam de bases valorativas ao processo que se investigue, é possível vislumbrar a aplicação das consequências do objeto de nosso estudo.
} 
ser extraídas de seu comportamento, de modo que a boa-fé e a cooperação ganham também contornos especiais ${ }^{10}$.

Com isso, não se afirma que inexiste espaço para vedação da contradição no âmbito do Processo Penal ${ }^{11}$, mas apenas que, para tanto, será preciso estudo especializado que parta das premissas valorativas concernentes ao Processo Penal, o que não se inclui no objeto desse trabalho.

\footnotetext{
${ }^{10}$ A título ilustrativo, valem as advertências de JULIO CHIAPPINI: "Respecto al proceso penal, pues ni hablar. Porque ya se sabe que el imputado, en su afán de desinvolucrarse, va a apelar a cuanta versión tenga a mano para exculparse, sea o no inocente. Esa proclividad natural y el principio da inocencia, entre otras raziones, coadyuvan a que la doctrina de marras deba ser tomada, en este tipo de procesos, con la mayor precaución. Por ejemplo, la autocontradicción podría (con otras pruebas) bastar para un auto de procesamiento, decisión incriminatoria, sí, pero de probabilidad. Su fuerza, en cambio, para una sentencia de condena, se enerva un tanto." (La doctrina de los propios actos: errones, p. 700).

${ }^{11}$ Pelo contrário, a aplicação possível é evidenciada na análise da jurisprudência realizada no Capítulo 2 infra; na oportunidade, constatamos que de todos os 82 (oitenta e dois) casos de venire processual encontrados, 30 (trinta) foram identificados no contexto do Processo Penal.
} 


\section{ANÁLISE PRELIMINAR DA JURISPRUDÊNCIA}

A pesquisa jurisprudencial realizada não tem a pretensão de esgotar as hipóteses em que a referência à vedação de comportamentos contraditórios em âmbito processual foi feita por nossos tribunais. O objetivo é evidenciar a realidade de que o venire já vem sendo aplicado no processo, de maneira expressiva, e gerando consequências diversas. Assim, a descrição a seguir tem natureza exemplificativa, propondo-se classificações didáticas que servirão de base para identificar os problemas a serem enfrentados, bem como para justificar a pertinência dos demais temas abordados no decorrer do trabalho, mas que de maneira nenhuma pretendem ser exaustivas ou ter caráter conclusivo.

\subsection{Fenômeno quantitativamente expressivo}

Tendo em vista que a ideia de estudar o comportamento contraditório no Processo partiu da leitura de um caso específico do Superior Tribunal de Justiça, em que a Ministra NANCY ANDRIGHI afirma que "do mesmo modo que, no direito civil, o comportamento contraditório implica violação do princípio da boa-fé objetiva, é possível também imaginar, ao menos num plano inicial de raciocínio, a violação do mesmo princípio no processo civil" ${ }^{\prime 2}$, a primeira preocupação foi averiguar se o mesmo fenômeno era identificável em outros casos, ou seja, se o venire processual já é uma realidade admitida pelos tribunais, até mesmo para se identificar a viabilidade do estudo ora proposto.

Considerando o escopo exemplificativo fixado, a análise, em um primeiro momento, limitou-se à jurisprudência do Superior Tribunal de Justiça (STJ) e do Supremo Tribunal Federal (STF), utilizando-se como parâmetros de pesquisa os termos "venire", "comportamento contraditório" e "comportamento processual contraditório". Eliminando-

${ }^{12}$ STJ, MC 15398/RJ, Rel. Ministra NANCY ANDRIGHI, TERCEIRA TURMA, julgado em 02/04/2009, DJe 23/04/2009. 
se os resultados coincidentes obtidos com cada parâmetro de pesquisa, foram encontrados 10 (dez) casos no STF e 138 (cento e trinta e oito) no STJ ${ }^{13}$.

Desse montante total, foi preciso estabelecer um critério de separação entre as hipóteses em que o venire foi invocado em um contexto processual ${ }^{14}$ e aqueles casos em que a ele se fez referência em contextos tipicamente de outras áreas do Direito, como a do Direito Civil. E aqui surgiu o primeiro problema: como separar os casos de venire processual dos demais?

Isso porque, como se afirmou e como se verá de maneira detalhada a seguir (item 3.1 infra), para que se possa falar em vedação a comportamentos contraditórios, pressupõe-se a existência de, minimamente, duas condutas: a primeira geradora de expectativas em terceiros, e a segunda, que contrarie essas mesmas expectativas. Tais condutas, por sua vez, podem ser ambas praticadas no curso de um processo (ainda que em processos distintos, problemática que enfrentaremos adiante), ambas fora dele, ou cada uma em momentos diversos, ou seja, fora da sede processual e dentro dela. Serão objeto de estudo aprofundado as espécies de situações processuais que podem dar espaço à aplicação do venire no processo, mas, por ora, para essa análise preliminar da jurisprudência consideramos os três critérios seguintes para realizar essa separação.

Em primeiro lugar, foram identificados como venire processual aqueles casos em que os próprios julgadores classificam a manifestação do fenômeno como sendo em âmbito processual, utilizando-se de expressões como "no sistema das invalidades processuais deve-se observar a necessária vedação ao comportamento contraditório, cuja rejeição jurídica está bem equacionada na teoria do venire contra factum proprium, em abono aos princípios da boa-fé e da lealdade processual"15; "assim agindo, o Poder Judiciário feriu a máxima nemo potest venire contra factum proprium, reconhecidamente aplicável no âmbito processual"16; "a ninguém é dado comportar-se contraditoriamente no

\footnotetext{
${ }^{13}$ Disponível em <http://www.stj.jus.br/> e <http://www.stf.jus.br/>. Acesso em 31.10.2014.

${ }^{14}$ Também foram analisados casos de comportamentos contraditórios processuais observados no contexto do Processo Penal, pois se observou que, apesar de terem sido identificados nessa seara, o venire se configurou pelo exercício de condutas que também poderiam ter sido observadas no Processo Civil. Como exemplo, cita-se o Habeas Corpus em que se considerou contraditório o comportamento da parte que alega a nulidade da citação pela ausência do recebimento da contra-fé diante do fato de ela ter sido citada pessoalmente e, portanto, teria a oportunidade, a qualquer tempo, de tomar conhecimento do teor da demanda, o que deixou de fazer em afronta à boa-fé processual (STJ, HC 155056/RJ, Rel. Ministra MARIA THEREZA DE ASSIS MOURA, SEXTA TURMA, julgado em 06/12/2012, DJe 13/12/2012).

${ }^{15}$ STF, HC 104185/RS, Rel. Ministro GILMAR MENDES, SEGUNDA TURMA, Julgado em 02/08/2011, DJe em 05/09/2011.

16 STJ, REsp 1306463/RS, Rel. Ministro HERMAN BENJAMIN, SEGUNDA TURMA, julgado em 04/09/2012, DJe 11/09/2012.
} 
processo"17; "não se admite, no direito processual brasileiro, o venire contra factum proprium"18; "o sistema processual civil não se compraz com o comportamento processual contraditório" 19 , entre muitas outras. E, da mesma forma, evidenciando-se a preocupação apenas com a relação de direito material, o venire foi considerado como material.

Em segundo lugar, para as hipóteses em que o venire foi mencionado sem uma referência expressa a um contexto de direito material ou processual, considerou-se que, quando as duas condutas correspondem a situações jurídicas processuais, o venire foi classificado como processual. E, portanto, quando tais condutas são ambas praticadas em contextos negociais ou de direito material, o venire foi enquadrado como sendo de outros ramos do direito.

Assim, v.g., considerou-se como venire processual a hipótese em que uma das partes alega nulidade pela utilização de prova emprestada no processo sendo que, anteriormente, havia expressamente concordado com o aproveitamento dessa mesma prova $^{20}$. Note-se que, aqui, os dois comportamentos contraditórios representam situações jurídicas processuais - concordância com a utilização da prova e posterior insurgência, ambas as alegações formuladas no processo -, motivo pelo qual o julgado foi classificado como sendo de venire processual.

De outro lado, na hipótese em que se reconheceu a configuração do venire por parte do Estado, que cobra Imposto sobre a Propriedade Territorial Rural apesar de não ter cumprido com seu dever de garantir a propriedade do contribuinte, vez que ela foi invadida pelo Movimento "Sem Terra",21, independentemente da análise quanto ao cabimento ou não da incidência do venire, o fato é que ele foi configurado a partir de duas condutas de direito material, que de modo algum se relacionam com qualquer processo (até porque, são duas condutas tomadas antes da existência do processo judicial), o que nos fez classificar esse caso, à semelhança de outros, como de venire material.

\footnotetext{
${ }^{17}$ STJ, REsp 1094223/MG, Rel. Ministro ALDIR PASSARINHO JUNIOR, QUARTA TURMA, julgado em 24/08/2010, DJe 10/09/2010.

${ }^{18}$ STJ, RMS 29356/RJ, Rel. Ministro BENEDITO GONÇALVES, PRIMEIRA TURMA, julgado em 06/10/2009, DJe 13/10/2009.

${ }^{19}$ STJ, AR 3579/MG, Rel. Ministro SIDNEI BENETI, SEGUNDA SEÇÃO, julgado em 27/10/2010, DJe 07/02/2011.

${ }^{20}$ STJ, HC 143414/MS, Rel. Ministra MARIA THEREZA DE ASSIS MOURA, SEXTA TURMA, julgado em 06/12/2012, DJe 13/12/2012.

${ }^{21}$ STJ, REsp 1144982/PR, Rel. Ministro MAURO CAMPBELL MARQUES, SEGUNDA TURMA, julgado em 13/10/2009, DJe 15/10/2009.
} 
Em resumo, como critérios utilizados para essa separação preliminar da análise da jurisprudência, sem qualquer pretensão ainda conclusiva: se houve menção expressa dos julgadores como sendo caso de venire no processo, bem como se ambas as condutas correspondem a situações jurídicas processuais, o julgado foi classificado como de venire processual. Se, todavia, os dois atos não possuíam relação com qualquer processo, esse venire foi classificado como de direito material.

A dúvida surge quando identificados inúmeros casos em que a vedação ao comportamento contraditório foi feita considerando um primeiro ato praticado fora do processo e, o segundo, no desenvolver da relação jurídica processual. Geralmente, isso ocorre pela prática de um primeiro ato a partir do qual são geradas expectativas que, por sua vez, são contrariadas por alegações feitas no decorrer do trâmite processual - espécie bastante frequente nas pesquisas realizadas. Como exemplo, pode-se citar a insurgência da União, manifestada no curso de um processo, quanto ao reconhecimento da insalubridade das condições de trabalho de um servidor público sendo que, em âmbito administrativo, ela mesma reconhecera essa insalubridade ${ }^{22}$.

A classificação dessa espécie de venire como sendo de direito material ou processual somente poderá ser mais bem compreendida após a exposição dos pressupostos da teoria no Direito Civil, bem como depois de fixados os elementos configuradores do venire em âmbito processual. Todavia, já adiantando a explicação do item 8.2.1. infra, consideramos tais situações como também de venire processual, uma vez que a confiança foi rompida dentro da sede processual, fazendo-se necessário reestabelecer a confiança do processo.

Diante dessas observações, os resultados obtidos foram os seguintes: dos 10 (dez) casos relacionados a comportamentos contraditórios encontrados nos Supremo Tribunal Federal, 4 (quatro) são de venire processual, 5 (cinco) são de direito material, e um não possui aplicação do venire, a palavra é apenas citada como palavra-chave, sem correspondência no corpo do voto. Já no Superior Tribunal de Justiça, dos 138 (cento e trinta e oito) casos analisados, 109 (cento e nove) são de venire processual, 23 (vinte e três

22 STJ, AgRg no Ag 1407965/PR, Rel. Ministro ARNALDO ESTEVES LIMA, PRIMEIRA TURMA, julgado em 15/05/2012, DJe 18/05/2012. 
são de direito material e 6 (seis) citaram as expressões utilizadas como parâmetro de pesquisa mas sem que houvesse efetiva discussão sobre o tema ${ }^{23}$.

Nota-se, portanto, a expressividade quantitativa da invocação da vedação a comportamentos contraditórios em contextos processuais, superando os casos em que citada no contexto do direito material pelo Superior Tribunal de Justiça, o que justifica a pesquisa proposta, principalmente para que se possa medir esses mesmos julgados em termos qualitativos, ou seja, para se analisar se houve aplicação apropriada do princípio.

\subsection{Os diversos efeitos observados}

A análise da jurisprudência relativa ao tema não só surpreendeu quanto aos resultados obtidos com relação à expressividade quantitativa da aplicabilidade do venire no processo, mas também pela diversidade de consequências decorrentes dessa aplicação. Com base nisso, buscou-se mapear as manifestações conforme os reflexos observados no processo, ressaltando-se, mais uma vez, o escopo exemplificativo da classificação.

E, a fim de se identificar o maior número possível de consequências decorrentes da aplicação do venire, a pesquisa foi estendida também ao Tribunal de Justiça do Estado de São Paulo, pois, considerando suas proporções em termos de número de processos e diversidade de matérias abordadas, ele fornece um espaço amostral significativo, capaz de proporcionar a riqueza de dados necessária à completude da pesquisa $^{24}$. Assim, passa-se à classificação não exaustiva do venire, conforme as diferentes consequências jurídicas identificadas na jurisprudência.

\subsubsection{Inexistência de nulidade}

\footnotetext{
${ }^{23}$ Vale ressaltar a expressividade do número de venire processuais usando-nos apenas dos critérios iniciais, ou seja, quando o próprio julgador afirma que se trata de venire no processo, bem como quando a contradição se dá por meio do exercício de duas condutas unicamente processuais. Só com base nisso, já seriam 82 casos de venire processual.

${ }^{24}$ Considerando os resultados obtidos pela pesquisa elaborada pelo Ministério da Justiça, Diagnóstico do Poder Judiciário, tem-se que a Justiça Comum é responsável pela grande maioria dos processos do país (73\% em 2004) e, dentro dela, a Justiça Paulista possui os maiores índices de litigiosidade, e maior número de processos distribuídos: dos 11.939.606 processos distribuídos à Justiça Comum em 2003, 5.845.111 foram ajuizados perante a Justiça Paulista, o que corresponde a 48,9\% do total. (Disponível em <http://www.migalhas.com.br/arquivo_artigo/diagnostico_web.pdf>. Acesso em 06 mar. 2013).
} 
A grande maioria dos casos se insere nessa classificação. São hipóteses em que a análise de um ato processual, se isoladamente considerado, culminaria na necessária declaração de sua nulidade, por sua prática inobservar a forma prevista em lei; mas, levando-se em conta um contexto processual mais amplo, percebe-se que o eventual reconhecimento de nulidade afrontaria as expectativas geradas pela própria parte que dele se beneficiaria, motivo pelo qual, a fim de se vedar comportamentos processuais contraditórios, a nulidade deixa de ser declarada. Os exemplos desse tipo de aplicabilidade são os mais variados.

Uma hipótese bastante comum de invocação do princípio nemo potest venire contra factum proprium no processo é aquela em que as partes alegam nulidade pelo fato de o julgamento antecipado da lide representar cerceamento de defesa, ao passo que, anteriormente, elas mesmas deixaram de especificar provas no prazo oportuno, ou ainda, expressamente dispensaram a fase probatória ${ }^{25}$.

No HC n. 108476, v.g., a parte ré alegou nulidade por ter apresentado alegações finais antes da acusação, o que, em tese, afronta o antigo art. 500 do Código de Processo Penal ${ }^{26}$. Mas se deixou de reconhecer a nulidade tendo em vista que a própria parte ré, em momento anterior do processo, atesta que se antecipou espontaneamente, apresentando alegações finais antes de ser intimada e, portanto, antes da acusação ${ }^{27}$.

\footnotetext{
${ }^{25}$ Nesse sentido, $c f$. o REsp 876682/PR do Superior Tribunal de Justiça. Ao apreciar a matéria da nulidade por cerceamento de defesa, aduz o Ministro MAURO CAMPBELL que "Não obstante o juízo singular tenha julgado antecipadamente a lide, tal julgamento levou em consideração o pedido expresso de não produção de provas formulado por ambas as partes. Especificamente em relação à autora, ela mesma admite em suas razões de recurso especial que 'abriu mão da produção de provas pois considerava que a extensa prova documental acostada à petição inicial já era apta e suficiente para atestar a existência do crédito de ICMS em face do Estado do Paraná' (fls. 726). Nesse contexto, o entendimento adotado pelo Tribunal de origem, no sentido de julgar improcedente o pedido por inobservância da regra contida no art. 333, I, do CPC, não implica ofensa aos arts. 130, 330, I, e 331, § $2^{\circ}$, do CPC. A jurisprudência desta Corte, com base no princípio da boa fé objetiva, tem consagrado a proibição do venire contra factum proprium". (STJ, REsp 876682/PR, Rel. Ministro MAURO CAMPBELL MARQUES, SEGUNDA TURMA, julgado em 22/06/2010, DJe 05/08/2010). Ver, ainda: TJSP, Apelação n. 9121716-26.2009.8.26.0000, $22^{\mathrm{a}}$ Câmara de Direito Privado, Des. Rel. Campos Mello, deram parcial provimento, Julgado em 18/03/2012. E, por fim, fenômeno semelhante foi identificado na Espanha, conforme relato de JOAN PICÓ I JUNOY, El principio de la buena fe procesal, p. 127.

26 “Art. 500. Esgotados aqueles prazos, sem requerimento de qualquer das partes, ou concluídas as diligências requeridas e ordenadas, será aberta vista dos autos, para alegações, sucessivamente, por três dias: I - ao Ministério Público ou ao querelante; II - ao assistente, se tiver sido constituído; III - ao defensor do réu." Esse artigo foi posteriormente revogado pela Lei n. 11.719, de 2008.

${ }^{27}$ Nas palavras do Ministro: "Nesse diapasão, entendo que, levando em conta o fato de a defesa do paciente ter convergido para ocorrência da suposta nulidade - inversão da ordem de apresentação das alegações finais —, não pode, em momento posterior, visando a beneficiar-se de seu primeiro ato, vir a requerer a anulação do julgamento. É que tal comportamento, para mim, é inequivocamente contraditório, devendo, portanto, ser refutado." (STF, HC 108476/PE, Rel. Ministro GILMAR MENDES, SEGUNDA TURMA, Julgado em 27/03/2012, DJe em 13/04/2012).
} 
Exemplo de grande interesse é a ação rescisória na qual, dentre as alegações formuladas, buscou-se a rescisão do julgado que se fundou em perícia realizada em outro processo, ou seja, os autores da rescisória buscavam a nulidade pela utilização de prova emprestada $^{28}$. Ocorre que o pedido foi afastado com base no fato de que, quando da postulação de provas no processo, os autores, então réus, não pleitearam produção de prova pericial, e mais, não se insurgiram durante as discussões feitas com base na prova emprestada, providenciada a pedido dos então autores. Assim, deixou-se de declarar a nulidade com base na concordância tácita dos autores da rescisória, do que decorre a discussão quanto à possibilidade de o comportamento omissivo da parte - que deixou de se insurgir contra a prova emprestada em momento oportuno - gerar expectativas que não podem ser frustradas por comportamento posterior.

\subsubsection{Ausência de interesse de agir}

Há casos na jurisprudência em que foi considerado ausente o interesse de agir da parte que, ao formular uma pretensão recursal ou mesmo ao formular o pedido de tutela jurisdicional, entra em contradição com comportamento por ela mesma anteriormente praticado.

A falta de interesse recursal é mais comumente atrelada à figura do venire. Identifica-se com frequência, por exemplo, a hipótese em que a parte celebra acordo, desiste da pretensão recursal e, em seguida, interpõe recurso contra a sentença homologatória. É esse o caso do Mandado de Segurança n. 25742 julgado pelo Supremo Tribunal Federal, no qual se entendeu que "homologada a desistência, insurge-se o impetrante contra atos por ele mesmo praticados, aliás, de forma reiterada e clara. Não há como nem por onde admitir tal pretensão que, de um lado, viola a proibição de venire contra factum proprium, com a surpreender a outra parte da causa" ${ }^{, 29}$.

Ocorre que, para suportes fáticos iguais ao descrito, a legislação processual já previu norma jurídica específica, a saber, o art. 503 do Código de Processo Civil, que

\footnotetext{
${ }^{28}$ TJSP, Ação Rescisória n. 9008591-71.1995.8.26.0000, Segundo Grupo de Câmaras de Direito Privado, Des. Rel. JOSÉ OSÓRIO, julgaram improcedente, Julgado em 12/02/1998.

${ }^{29}$ STF, Ag. Reg. no MS 25742/DF, Rel. Ministro CEZAR PELUSO, Tribunal Pleno, Julgado em 05/04/2006, DJe 25/08/2006. No mesmo sentido, $c f$. TJSP, Apelação n. 209467-98.2009.8.26.0100, $6^{\text {a }}$ Câmara de Direito Privado, Des. Rel. Paulo Alcides, negaram provimento, Julgado em 08/03/2012.
} 
determina que "a parte, que aceitar expressa ou tacitamente a sentença ou a decisão, não poderá recorrer", o que a doutrina identifica como uma das hipóteses de preclusão lógica. Daí ser necessário buscar a diferenciação, se é que existente, entre venire e preclusão lógica, o que será feito no Capítulo 7 infra.

Já no julgamento da Medida Cautelar n. $15398^{30}$, não foi a pretensão recursal que foi considerada sem interesse de agir, mas a própria tutela jurisdicional: foi extinta sem exame do mérito uma medida cautelar, ajuizada para conceder efeito suspensivo ao Recurso Especial interposto contra acórdão que apreciou pedido liminar de antecipação de tutela em uma ação declaratória, tendo por motivo da extinção justamente a identificação de venire processual da parte requerente que, ao perder a mesma ação por ela ajuizada perante a jurisdição da Inglaterra, buscou a jurisdição brasileira.

Assim, ponderou-se que, não obstante o reconhecimento da jurisdição brasileira para apreciação da matéria, vez que "não se pode declinar da competência internacional para o julgamento de uma causa com fundamento na mera existência de trânsito em julgado da mesma ação, no estrangeiro" - pela inexistência de vedação ao forum shopping ${ }^{31}$ ou do forum non conveniens $^{32}$ na lei brasileira -, o ajuizamento da mesma ação, pleiteando o mesmo bem da vida, pela mesma parte, e que já tinha sido vencida pela Justiça Inglesa, configura comportamento contraditório que afronta a boa-fé processual. E, com base nisso, houve indeferimento da liminar e extinção da medida cautelar sem exame do mérito.

Trata-se de uma das consequências mais interessantes de todas as identificadas. Afinal, essa figura que sequer possui atenção da doutrina processualista é capaz de

\footnotetext{
${ }^{30}$ STJ, MC 15398/RJ, Rel. Ministra NANCY ANDRIGHI, TERCEIRA TURMA, julgado em 02/04/2009, DJe e23/042009.

31 "A expressão forum shopping se refere à procura de uma jurisdição em que as partes, ou uma delas, pensa que lhe será feita melhor justiça, ou onde terá mais probabilidade de êxito, por uma ou por outra razão" (JACOB DOLINGER, Direito internacional privado: parte geral, p. 434). Segundo FrEDIE DIDIER JR. "Há situações em que existem vários foros em princípio competentes para o conhecimento e julgamento de uma demanda; (...) $\mathrm{O}$ autor, diante dessas opções, exercita aquilo que já se denominou como forum shopping: a escolha pelo foro do demandante. Escolher o foro dentre aqueles em tese competentes é direito potestativo do autor. (...) O problema é conciliar o exercício desse direito potestativo com a proteção da boa-fé" (Curso de Direito Processual Civil, v. 1, p. 142).

${ }^{32} \mathrm{O}$ forum non conveniens pode ser definido como a possibilidade de o juízo recusar o exercício da jurisdição quando identificado outro foro competente e mais adequado ao julgamento da causa, principalmente por ser muito inconveniente a uma das partes. É, portanto, uma limitação ao forum shopping. (FREDIE Didier JR, Curso de Direito Processual Civil, v. 1, pp. 143-144). Segundo referido autor, essa teoria se aplica ao Brasil com base no princípio da boa-fé.
} 
condicionar a pretensão recursal e até mesmo o direito à obtenção da tutela jurisdicional de mérito, o direito processual de ação ${ }^{33}$.

\subsubsection{Invalidação da decisão judicial}

Quando duas decisões judiciais são contraditórias entre si, de modo a ferir expectativas geradas nas partes, a jurisprudência identificou espaço para a incidência do venire, invalidando-se essa segunda decisão ${ }^{34}$ de modo a proteger a confiança decorrente da primeira manifestação judicial.

Isso é revelado, por exemplo, pela análise do Recurso Especial n. $1306463^{35}$, o qual representa a insurgência das partes quanto ao não recebimento do recurso de apelação, considerado pelo Juízo de Primeiro Grau intempestivo. Em uma primeira decisão, o magistrado homologara o pedido de suspensão do processo por noventa dias. Ocorre que, ainda não esgotado o prazo da suspensão, foi proferida e publicada a sentença. As partes interpuseram o recurso apenas findo o prazo de noventa dias, mas, por terem sido ultrapassados os quinze dias da publicação da sentença, a apelação foi considerada intempestiva.

Analisando o caso, considerou-se que a decisão de intempestividade feriu a confiança anteriormente gerada nas partes, pois, "ao homologar a convenção pela suspensão do processo, o Poder Judiciário criou nos jurisdicionados a legítima expectativa de que o processo só voltaria a tramitar após o prazo convencionado". E, com base na vedação a comportamentos processuais contraditórios, reformou-se a decisão e passou-se a admitir a apelação interposta.

\footnotetext{
${ }^{33}$ Sobre o direito processual de ação, $c f$. EnRICo Tullio Liebman, Manual de Direito Processual Civil, vol. 1, pp. 197-203; SuZANa Henriques Da Costa, Condições da ação, pp. 39-42; CÂNDIDO Dinamarco, ARAÚJo CINTRA e ADA PELlegrinI, Teoria Geral do Processo, pp. 271-274.

${ }^{34}$ Utiliza-se o termo "invalidação" porque, nos casos aqui analisados, a identificação pelos julgadores do venire entre decisões implicou considerar a segunda decisão como error in procedendo. Afinal, não é o conteúdo dela que, per si, afronta as normas jurídicas, até porque, se analisada isoladamente, não haveria necessidade de reforma. Pelo contrário, somente em razão do contexto processual e do fato de a segunda decisão ser contraditória à primeira é que ela se torna vedada. Essa distinção ficará mais clara quando este item for comparado com o item 2.2.4 infra.

${ }^{35}$ STJ, REsp 1306463/RS, Rel. Ministro HERMAN BENJAMIN, SEGUNDA TURMA, julgado em 04/09/2012, DJe 11/09/2012.
} 
$\mathrm{Na}$ mesma linha argumentativa, no Recurso Especial n. $1116574^{36}$, foi considerada contraditória a decisão de Primeiro Grau que extinguiu sem exame do mérito os embargos do devedor, por ausência de preparo, se em momento anterior foi conferido prazo suplementar para o embargante recolher as custas faltantes, o que foi providenciado. Concluiu-se que "a conduta do Juízo a quo revela-se contraditória e viola o princípio insculpido na máxima nemo potest venire contra factum proprium, na medida em que anteriormente determinou - quando não precisava fazê-lo - a intimação para recolhimento do preparo e, ato contínuo, mesmo após o cumprimento de sua ordem, entendeu por bem julgar extinta a demanda, sem julgamento de mérito.”.

Portanto, as decisões judiciais, capazes de gerar expectativas no curso da relação jurídica processual, são interpretadas pelos julgadores como atos processuais que, uma vez conflitantes entre si, podem dar ensejo à aplicação do nemo potest venire contra factum proprium. Trata-se de peculiaridade do direito processual, cuja relação jurídica normalmente se desenvolve de maneira triangular com a intervenção da figura do Estadojuiz, o que não ocorre nas relações puramente de direito negocial e por isso se justifica um estudo especializado.

\subsubsection{Reforma do conteúdo decisório}

Diferentemente do item anterior, há casos em que a própria apreciação do pedido ou questão incidental, pelo magistrado, revela contradição no caminho lógico percorrido, de modo que o venire é utilizado como justificativa para a reforma da decisão. Neste caso, portanto, a contradição significa error in iudicando.

Assim se considerou quando do julgamento do HC n. $166123^{37}$, por meio do qual houve reforma da sentença que, ao mesmo tempo em que afastou a incidência da transnacionalidade como causa de aumento de pena, utilizou-a como circunstância judicial a justificar a aplicação da pena base acima do mínimo legal. Dessa maneira, configurou-se contradição no julgamento e que "em processo penal, vedam-se aos sujeitos processuais, inclusive a juiz, comportamentos contraditórios (venire contra factum proprium),

${ }^{36}$ STJ, REsp 1116574/ES, Rel. Ministro MASSAMI UYEDA, TERCEIRA TURMA, julgado em 14/04/2011, DJe 27/04/2011.

${ }^{37}$ STJ, HC 166123/AC, Rel. Ministro OG FERNANDES, SEXTA TURMA, julgado em 05/08/2010, DJe $13 / 12 / 2010$. 
exigindo-se uma conduta harmônica com o devido processo legal e a boa-fé processual, de acordo com as justas expectativas produzidas no curso do feito".

Outra hipótese de error in iudicando pelo raciocínio contraditório da fundamentação da decisão judicial apontada pela jurisprudência é aquela em que o julgador inicia a sentença justificando o cabimento do julgamento antecipado da lide, pelas questões controvertidas serem apenas de direito ou dispensarem dilação probatória (art. 330 do Código de Processo Civil) e, em momento seguinte da própria sentença, invoca a regra de distribuição do ônus probatório para embasar sua decisão. A contradição é apontada como existente no fato de que o ônus da prova, quando invocado pela sentença, serve de regra de julgamento extremamente útil aos casos em que há carência de acervo probatório nos autos ${ }^{38}$. Mas, se o próprio juiz dispensou a produção de provas, não pode basear seu julgamento impondo às partes que arquem com as consequências de um ônus do qual não tiveram oportunidade de se desincumbir ${ }^{39}$.

Temos ressalvas quanto à invocação do venire processual para solução desse tipo de contradição na medida em que esses atos contraditórios são praticados em um mesmo momento processual, bem como pelo fato de que os embargos de declaração prevêem hipótese de solução desse tipo de contradição. Surgem, assim, novas questões a serem enfrentadas no decorrer do trabalho ${ }^{40}$.

\subsubsection{Desconsideração da alegação (ou inadmissibilidade do segundo ato da parte)}

São infindáveis os exemplos em que o venire contra factum proprium foi referido nos julgamentos como forma de apontar a contradição entre alegações formuladas pelas partes, e, por causa dessa contradição, uma das alegações passa a ser simplesmente

\footnotetext{
${ }^{38}$ A despeito da discussão doutrinária quanto à dupla funcionalidade da regra de distribuição do ônus da prova (regra de julgamento e regra de conduta), é seguro afirmar que, quando invocada pela sentença, ela está sendo utilizada apenas como regra de julgamento, ou seja, destina-se "a fornecer ao julgador meios de proferir a decisão, quando os fatos não restaram suficientemente provados" (JOSÉ ROBERTO DOS SANTOS BEDAQUE, Poderes instrutórios do juiz, p. 120 - grifou-se).

${ }^{39}$ Nesse sentido: TJSP, Apelação n. 9166848-09.2009.8.26.0000, 20ª Câmara de Direito Privado, Des. Rel. MARIA LÚCIA PIZZOTTI, julgado em 22/10/2012; e TJSP, Apelação n. 0005502-51.2008.8.26.0191, $5^{\text {a }}$ Câmara de Direito Privado, Des. Rel. Francisco Bianco, julgado em 18/06/2012.

${ }^{39}$ STJ, EDcl no Ag 1318082/SP, Rel. Ministro LUIS FELIPE SALOMÃO, QUARTA TURMA, julgado em 10/04/2012, DJe 16/04/2012.

${ }^{40}$ Essa questão foi mais bem analisada no item 8.3. infra.
} 
desconsiderada, sem qualquer credibilidade para influenciar no convencimento do julgador.

Cita-se, por exemplo, os Embargos de Declaração no Agravo de Instrumento n. 1318082, em que o recorrente impugna a qualidade técnica do perito, principalmente por não ter contribuído com o CREA, sendo que, no curso do processo, o assistente técnico dessa mesma parte recorrente "elogiou expressamente os serviços do perito, não podendo, agora, opor um comportamento contraditório (venire contra factum proprium) ao aduzir que há inaptidão do expert ${ }^{\prime 41}$.

Da mesma forma, contraditórias as alegações da parte que, sendo ré condenada na primeira fase da ação de prestações de contas, presta-as e, posteriormente, impugna-as. “Com efeito, tendo (...) sido julgadas boas as contas prestadas pelo próprio recorrente, não há falar que a decisão extrapolou os limites do pedido exordial, pois o princípio da boa-fé objetiva obsta à parte assumir comportamentos contraditórios no decorrer da relação processual, sendo, pois, vedado o venire contra factum proprium" ${ }^{\text {,42. }}$.

O Superior Tribunal de Justiça também reconheceu contradição entre alegações no caso em que a parte opôs embargos de declaração contra acórdão de Segunda Instância, a fim de provocar a manifestação específica do Tribunal com relação a alguns dos temas por ela apontados e, perante o Superior Tribunal, sustentou já ter havido, mesmo antes da oposição dos embargos, o prequestionamento de toda a matéria. Identificou-se que, "tendo a parte suscitado embargos de declaração para provocar a manifestação do Tribunal de origem a respeito dos temas que pretendia discutir no Recurso Especial, é porque reconheceu, naquela oportunidade, que eles não estavam devidamente prequestionados. Assim não pode, posteriormente, afirmar o contrário, pois a ninguém é dado 'venire contra factum proprium,"43.

Muitos outros casos poderiam ser citados, mas os supra destacados já evidenciam esse tipo de aplicabilidade do princípio nemo potest venire contra factum proprium no processo, em que a alegação é refutada pelo fato de representar contradição a alegações anteriormente formuladas.

\footnotetext{
${ }^{41}$ STJ, EDcl no Ag 1318082/SP, Rel. Ministro LUIS FELIPE SALOMÃO, QUARTA TURMA, julgado em 10/04/2012, DJe 16/04/2012.

${ }^{42}$ STJ, REsp 1005727/RJ, Rel. Ministro LUIS FELIPE SALOMÃO, QUARTA TURMA, julgado em 24/04/2012, DJe 15/05/2012.

${ }^{43}$ STJ, AgRg no Ag 892068/RS, Rel. Ministro SIDNEI BENETI, TERCEIRA TURMA, julgado em 18/11/2008, DJe 01/12/2008.
} 


\subsubsection{Análise da capacidade econômica}

A fim de se coibir os abusos nos pedidos desnecessários de concessão da assistência judiciária gratuita, a jurisprudência considera venire contra factum proprium a formulação do pedido se há indícios de capacidade econômica.

Assim foi decidido no Agravo Regimental no Recurso Especial n. 1099550, pois sem qualquer hesitação a parte recorrente pagou os honorários periciais provisórios e, em momento posterior, requer a concessão do benefício: “é de se reconhecer que a agravante, ao pagar os honorários periciais provisórios, claramente demonstrou sua capacidade financeira de arcar com tais despesas, não podendo, em momento posterior, simplesmente alegar o contrário" ${ }^{, 4}$.

Similar é o caso em que a parte autora requer os benefícios da gratuidade na exordial, e o pedido não é explicitamente analisado: o magistrado se limita a determinar o recolhimento das custas, o que é prontamente providenciado pela autora nesta e nas demais oportunidades em que necessário o recolhimento de custas no curso do processo. Assim, em sede de apelação, sem trazer qualquer elemento modificativo de sua situação econômica, a gratuidade é indeferida de modo a se obstar comportamentos processuais contraditórios $^{45}$.

\subsubsection{Relevância do venire processual para a apreciação do mérito}

O Recurso Especial n. $605687^{46}$ merece destaque pelo fato de que o próprio pedido principal da ação foi afastado porque representava afronta a expectativas geradas em oportunidade anterior: em uma primeira ação de inexigibilidade do débito, a parte autora alegava que estava sendo cobrada indevidamente de ligações que jamais fizera. A

\footnotetext{
${ }^{44}$ AgRg no REsp 1099550/SP, Rel. Ministro ARNALDO ESTEVES LIMA, QUINTA TURMA, julgado em 02/03/2010, DJe 29/03/2010.

45 TJSP, Apelação n. 0081016-08.2008.26.0224, 6a Câmara de Direito Privado, Des. Rel. FORTES BARBOSA, não conheceram, julgado em: 12/04/2012.

46 STJ, REsp 605687/AM, Rel. Ministra NANCY ANDRIGHI, TERCEIRA TURMA, julgado em 02/06/2005, DJ 20/06/2005, p. 273.
} 
empresa ré, em sua defesa, juntou o detalhamento do registro de ligações referentes ao período impugnado, com a concordância do autor.

Ocorre que, tempos depois, o mesmo autor ajuizou ação indenizatória, visando à reparação de danos morais pela exposição de sua intimidade com o detalhamento das ligações. E essa ação foi julgada improcedente na medida em que seu próprio comportamento anterior de aceitação da apresentação de detalhamento se mostrava incompatível com a tutela jurisdicional pleiteada. Assim, a Min. NANCY ANDRIGHI decidiu que "não estava o recorrido obrigado a fornecer prova contra si mesmo e, portanto, não estava obrigado a autorizar a juntada, pela parte contrária, do detalhamento do registro das ligações telefônicas do seu celular, não sendo lícito que se insurgisse contra tal fato após tê-lo autorizado. Trata-se de aplicação do sábio ensinamento consagrado entre os romanos, segundo o qual 'nemo potest venire contra factum proprium"”.

Mesmo não sendo esse o único argumento utilizado para afastar o pedido indenizatório, a leitura da decisão nos permite afirmar que o pedido que se mostre incompatível com comportamento anterior pode ser vedado pela jurisprudência. Diferentemente dos casos em que se constata ausência de interesse de agir do pedido formulado, aqui houve apreciação do mérito, o qual foi rejeitado por significar atitude contraditória do autor.

\subsubsection{Perda da situação jurídica processual pela demora em exercê-la}

No Tribunal de Justiça do Estado do Paraná ${ }^{47}$, foi possível identificar um caso desta natureza, envolvendo a perda de uma situação jurídica em decorrência da demora em exercê-la. Em uma ação de execução de título executivo extrajudicial, foram opostos embargos à execução pelo devedor, os quais foram julgados parcialmente procedentes. Contra essa decisão ambas as partes apelaram, mas apenas uma das apelações foi juntada aos autos, vez que a outra se perdeu no cartório. O fato é que jamais se teve notícia da apelação interposta pelo credor. E, no trâmite daquele recurso interposto pelo devedor - ao

${ }^{47}$ Com relação a esse ponto, foram estendidos os mecanismos de pesquisa para além dos Tribunais Superiores e do Tribunal de Justiça do Estado de São Paulo. Isso porque nesses Tribunais não foram encontradas hipóteses de perda de uma situação jurídica processual em decorrência da demora em exercê-la, mas, considerando a notícia doutrinária da ocorrência dessa hipótese na vida forense - é o que descreve FREDIE DIDIER JR. no artigo Multa coercitiva, boa-fé processual e supressio: aplicação do duty to mitiate the loss no processo civil -, ampliamos as pesquisas para buscar um caso concreto exemplificativo do tema. 
qual foi negado provimento, motivo pelo qual foram opostos embargos de declaração, depois interposto Recurso Especial, até que se chegasse ao trânsito em julgado -, o credor não indicou a ausência da juntada da peça recursal. Em verdade, nunca se manifestou sobre o tema.

Somente quando iniciado o cumprimento de sentença, o cartório se deu conta do equívoco, e o juízo determinou o processamento da apelação interposta. Contra essa decisão foi interposto agravo de instrumento, oportunidade na qual o Tribunal considerou "que o referido lapso temporal mostra-se suficiente para caracterizar os efeitos do 'instituto da supressio' em relação à parte. Com o passar do tempo sem que o Banco apelante manifestasse qualquer interesse no Juízo de admissibilidade e no julgamento do seu recurso interposto, permitiu a criação de uma expectativa na parte contrária, ora agravante, ou seja, um estado de confiança de que não tinha nenhuma intenção em recorrer dos embargos à execução, devidamente julgados" ${ }^{48}$.

O próprio acórdão, por sua vez, aponta também o artigo 245 do Código de Processo Civil como fundamento para afastar o conhecimento da apelação perdida. Aduz que na primeira oportunidade o credor deveria ter dado notícia da ausência da juntada de sua peça recursal, e, ao não o fazer, precluiu o direito de manifestação nesse sentido.

Nota-se, mais uma vez, a coincidência entre as aplicações do venire ${ }^{49}$ e da preclusão, o que revela a necessidade de buscar a diferenciação entre essas figuras, se é que existente tal diferença, bem como averiguar se o venire se aplica ainda em casos em que a preclusão é excepcionada, como faz o próprio artigo 245, Parágrafo único, do Código de Processo Civil, ao afirmar que "não se aplica esta disposição às nulidades que o juiz deva decretar de ofício, nem prevalece a preclusão, provando a parte legítimo impedimento".

\footnotetext{
${ }^{48}$ TJPR, Agravo de Instrumento n. 557362-8, $15^{\text {a }}$ Câmara Cível, Rel. Des. JURANDYR SOUZA JUNIOR, deram provimento, julgado em 24/06/2009. E complementa o órgão julgador: "A mera expectativa, com o decorrer do tempo, tornou-se legítima pela prática e reiteração do mesmo comportamento de inércia da parte, cujo recurso fora temporariamente 'perdido', criando, assim, um real direito subjetivo à parte contrária, qual seja, o de que não havia mais a intenção pela parte contrária em recorrer da decisão proferida por ocasião do julgamento dos embargos. Ainda que inexista culpa pelo suposto desaparecimento do recurso, devido ao decurso do tempo em que o apelante permaneceu inerte, perdeu ele o direito de recorrer daquela decisão proferida por ocasião do julgamento dos embargos à execução.".

${ }^{49}$ Isso porque, conforme já alertamos, a perda de uma situação jurídica pela demora em exercê-la é o que se convencionou chamar de suppressio, que, para nós, nada mais é do que uma modalidade de venire. $\mathrm{O}$ Capítulo 3 infra abordará o tema.
} 


\subsection{Os diferentes sujeitos envolvidos na vedação de comportamentos processuais contraditórios}

Da descrição acima dos diversos casos em que já se aplicou o venire em um contexto processual, é possível depreender peculiaridades que, dada sua importância, merecem maior destaque, o que é feito neste subitem e no seguinte.

Quanto aos sujeitos relacionados ao venire processual, ressalta-se, mais uma vez, que não só com relação ao comportamento das partes é vedada a contradição, mas também no que concerne à conduta do juiz, fenômeno a ser detalhadamente estudado por não se observar correspondência com a doutrina tradicional civilista e, ao mesmo tempo, ser de bastante interesse ao processo (itens 7.4.2. e 8.2.2. infra).

Mas, ainda com relação aos sujeitos processuais, nota-se que nem sempre a jurisprudência identifica a contradição a partir do comportamento de um mesmo sujeito, mas sim de um mesmo polo de interesse, tal como ocorreu no caso da insurgência da parte sobre um laudo pericial que seu próprio assistente técnico houvera elogiado ${ }^{50}$. Dessa observação, surgem questionamentos: afinal, é possível que a contradição não se identifique entre comportamentos praticados exatamente pelo mesmo sujeito? Isso significa, em âmbito processual, vedar a contradição entre atos da parte e de seu advogado, deste em relação ao seu assistente técnico, entre outros?

O estudo do tema no âmbito do Direito Civil traz respostas a essas perguntas (item 3.1.4. infra), o que auxiliará na análise do fenômeno no processo.

\subsection{Os efeitos transcendem as barreiras endoprocessuais}

Uma das mais interessantes constatações a partir da análise da jurisprudência é a de que a identificação de comportamentos contraditórios nem sempre está atrelada a duas condutas praticadas no mesmo processo, verificando-se casos em que a conduta praticada em processo diverso acaba vinculando o comportamento da mesma parte em processo ulterior.

\footnotetext{
${ }^{50} C f$. STJ, EDcl no Ag 1318082, Rel. Ministro LUIS FELIPE SALOMÃO, QUARTA TURMA, julgado em
} 10/04/2012. 
Não se trata do questionamento já feito a respeito da classificação do venire como sendo processual na hipótese de uma das condutas ser praticada fora de qualquer sede processual e, a outra, no curso de um processo. O que nos chama a atenção, neste momento, é a ideia de que uma conduta processual exercida em processo anterior pode, segundo a aplicação jurisprudencial, vincular a conduta da parte em processo posterior, como ocorreu no caso da falta de interesse de agir para a propositura da mesma demanda já proposta perante a Justiça Inglesa, só que desta vez perante a Justiça Brasileira, ou ainda, no caso da improcedência da ação de indenização por danos morais fundada na utilização de documento autorizada pela própria autora em processo anterior, ambos os casos já referidos neste trabalho ${ }^{51}$.

A partir desses casos, inevitável questionar se esses efeitos do venire que transcendem as barreiras endoprocessuais são admitidos pelo sistema, já que um efeito equivalente só se observa quando incidente a coisa julgada material. Uma vez admitida essa possibilidade, mister averiguar os requisitos necessários para tanto.

\subsection{Síntese conclusiva da análise jurisprudencial}

Toda a análise da jurisprudência realizada teve como escopo demonstrar, primeiramente, que o venire processual é uma realidade inconteste no exercício da função jurisdicional, demonstrando-se que os tribunais aplicam o instituto de maneira muito mais expressiva do que se pode imaginar a priori e, ainda, gerando as mais diversas consequências.

Todavia, se certa a existência de um venire processual na jurisprudência, no decorrer de toda a descrição acima se mostrou ser bastante incerto o modo de aplicação do instituto, que varia quanto às consequências observadas, quanto aos contextos em que identificado, quanto aos sujeitos envolvidos e até mesmo quanto à sua funcionalidade no sistema.

\footnotetext{
${ }^{51}$ STJ, MC 15398/RJ, Rel. Ministra NANCY ANDRIGHI, TERCEIRA TURMA, julgado em 02/04/2009, DJe e23/042009 e STJ, REsp 1099550/SP, Rel. Ministro ARNALDO ESTEVES LIMA, QUARTA TURMA, julgado em 02/03/2010, DJe 29/03/2010, respectivamente. Mais uma vez, JOAN PICÓ I JUNOY dá notícias de que o fenômeno ocorre na Espanha, em que identificado um caso de venire em um processo civil com base no que a parte alegara em um processo trabalhista: El princípio de la buena fe procesal, p. 129.
} 
Destacam-se como dúvidas a serem dirimidas a possibilidade (i) de o venire processual se configurar por meio de atos praticados simultaneamente; (ii) de a omissão da conduta processual da parte ou do magistrado gerar expectativas que não podem ser posteriormente contrariadas; (iii) de o venire ser invocado como forma de esvaziar o interesse recursal da parte, sendo que já existente a preclusão lógica para essa finalidade; (iv) de aplicação da vedação à contradição ao magistrado; (v) de se considerar relevante para o processo atos praticados fora dele; (vi) de condutas exercidas em outros processos vincularem as partes e o juiz, entre tantas outras.

Em razão de todos esses questionamentos, justifica-se o estudo teórico sobre o tema. A partir da exposição de seus postulados desenvolvidos pela doutrina civilista, a proposta é estudar o fenômeno em âmbito processual, estabelecendo-se seus escopos, pressupostos de aplicabilidade, limites à aplicação, diferenciação em relação a outros institutos processuais com caraterísticas coincidentes, de modo a evitar a referência descabida ao princípio do nemo potest venire contra factum proprium no processo, seja porque desnecessária sua incidência, seja porque equivocadamente invocada.

É o que buscaremos fazer a seguir. 


\section{A VEDAÇÃO DE COMPORTAMENTOS CONTRADITÓRIOS NO DIREITO CIVIL}

A tarefa de estudar todos os principais pontos da doutrina do venire em âmbito civil não é das mais fáceis, dado o estágio avançado de estudo que a teoria possui nessa seara jurídica. Entretanto, ressaltando que o escopo não é realizar uma ampla revisão de tudo que já foi produzido sobre o tema, busca-se apenas destacar os principais pontos, para o auxílio do desenvolvimento de questões concernentes ao venire no Processo Civil.

\subsection{Conceito e pressupostos para a aplicação da teoria}

Surgida entre os romanos sem uma sistematização teórica, mas apenas na forma de regras específicas sobre o combate à incoerência nos comportamentos humanos $^{52}$, foram os glosadores, no século XII, os responsáveis pela referência do venire na similitude do que hoje conhecemos: foi encontrada na obra Brocardica, de Azo, um brocardo $^{53}$ referente a um princípio de proibição do comportamento contraditório, venire contra factum proprium nulli conceditur ${ }^{54}$. Ocorre que Azo também identificou em meio às normas romanas situações em que a contradição era expressamente permitida, o que dificultou a aceitação do venire contra factum proprium como princípio geral ${ }^{55}$.

O estudo do tema ficou adormecido durante os períodos denominados Renascentista e Iluminista. Ambos os movimentos eram demasiadamente liberais e avessos às ideias que significassem qualquer limitação da autonomia privada. A Revolução Francesa foi o maior dos reforços em favor do liberalismo, que possuía facetas políticas, sociais, econômicas e também jurídicas. Assim, o direito privado experimentou o apogeu da consagração da liberdade individual, o que influiu nas codificações dos séculos XVIII e

\footnotetext{
52 Menezes Cordeiro, Da boa fé no Direito Civil, p. 743; Alejandro Borda, La teoria de los actos propios, p. 13-19.

${ }^{53}$ Segundo ALEJANDRO BORDA, um brocardo consiste em uma breve representação de uma verdade jurídica extraída a partir de uma síntese de diversos textos romanos (La teoria de los actos propios, p. 20).

${ }^{54}$ JUDITH MARTINS-COSTA, A ilicitude derivada do exercício contraditório de um direito, p. 112.

55 ANDERSON SCHREIBER, A proibição de comportamento contraditório, p. 25.
} 
$\mathrm{XIX}^{56}$. Nesse contexto, o venire restringiu-se à retomada de algumas hipóteses de incidência específicas provenientes do direito romano, sem inovações significativas ${ }^{57}$.

Todavia, o tempo e as interações sociais demonstraram que tamanha liberdade era insustentável e precisava de restrições a fim de se atingir valores também relevantes, como o da igualdade e o da justiça. Assim, paralelamente aos movimentos sociais que surgiam em oposição ao liberalismo, o ordenamento jurídico sofria alterações e mudanças de paradigmas.

Sob o ponto de vista do direito privado, o individualismo e o dogma da autonomia da vontade são questionados, e a moralidade e a ética voltam a fazer parte das discussões jurídicas. É esboçada a existência de uma nova autonomia privada, não mais fundada na liberdade irrestrita individual, mas no exercício livre da vontade considerandose seus reflexos perante terceiros ${ }^{58}$.

É nesse contexto de desvalorização do individualismo exacerbado que surge espaço para retomada do estudo da vedação a comportamentos contraditórios, instituto que, a fim de tutelar a confiança, pressupõe a preocupação com o próximo, valor que só foi juridicamente consolidado como princípio a partir da segunda metade do século $\mathrm{XX}^{59}$.

O nemo postest venire contra factum proprium - para nós, a teoria da vedação a comportamentos contraditórios - pode ser conceituado como a proibição de se adotar um segundo comportamento que seja contraditório a um primeiro anteriormente exercido e que, por meio dessa contradição, firam-se legítimas expectativas emanadas da conduta inicial vinculante ${ }^{60}$.

\footnotetext{
${ }^{56}$ ANDERSON SCHREIBER, A proibição de comportamento contraditório, pp. 38-39.

${ }^{57}$ ANDERSON SCHREIBER, A proibição de comportamento contraditório, p. 45.

${ }^{58}$ JUDITH MARTINS-COSTA, A ilicitude derivada do exercício contraditório de um direito, p. 109.

${ }^{59}$ ANDERSON SCHREIBER, A proibição de comportamento contraditório, p. 50. A evolução histórica da teoria venire contra factum proprium não nos parece imprescindível para o desenvolvimento de nosso objeto de estudo e, por isso, a Dissertação não contém tópico dedicado ao tema. Todavia, para aqueles que pretendam se aprofundar nesse aspecto, $c f$. ANDERSON SCHREIBER, A proibição de comportamento contraditório, pp. 11-64; ERWIN RIEZLER, Venire contra factum proprium - Studien im Romischen, Englischen und Deutschen Civilrecht, Leipzig: Verlag Von Duncker \& Humblot, 1912, pp. 1-40, autor responsável pelo desenvolvimento doutrinário do tema na Alemanha do início do século XX; MENEZES CordEIRO, Da boa fé no Direito Civil, pp. 743-745; ALEJANDro BordA, La teoria de los actos propios, pp. 13-23; PAULO MOTA PINTO, Sobre a proibição do comportamento contraditório no direito civil, pp. 143-144; JUDITH MARTINSCosta, A ilicitude derivada do exercício contraditório de um direito, pp. 110-113.

${ }^{60}$ Marcelo Mesa e CARlos VIDE, La doctrina de los actos propios, p. 89; OMAR LuIS DiAz SOlime, La buena fe en la estructura procesal, p. 861; MARCELO DICKSTEIN, As funções da boa-fé objetiva e a proibição de comportamento contraditório, p. 94-95; MENEZES CORDEIRO, Da boa fé no Direito Civil, p. 742; LUCIANO DE CAMARGO PENTEADO, Figuras parcelares da boa-fé objetiva e venire contra factum proprium, p. 259; ANDERSON SCHREIBER, A proibição de comportamento contraditório, p. 96.
} 
Assim, o nemo potest venire contra factum proprium é um instrumento protetivo da confiança gerada por um comportamento praticado, de modo que o agente da conduta referência não mais deva contradizer-se por meio da prática de ato posterior, sob pena de gerar prejuízo àqueles que objetivamente aderiram à confiança emanada pelo primeiro ato.

Quanto aos pressupostos para a aplicabilidade dessa teoria, os autores divergem na medida em que privilegiam um ou outro requisito, ou, por vezes, destacam a autonomia de um pressuposto que, para outro autor, está contido em pressuposto diverso. $\mathrm{E}$ ainda, encontram-se divergências doutrinárias com relação a alguns dos requisitos, tais como o que se refere à identidade de sujeitos ativos e passivos, ou no que concerne à existência ou não de algum elemento subjetivo para a configuração do venire.

Optamos pela classificação mais simples, para facilitar a compreensão da incidência do fenômeno, tratando de cada peculiaridade e divergência teórica dentro dos pressupostos elencados. São eles: (i) o factum proprium; (ii) a confiança gerada por esse factum; (iii) um segundo comportamento contraditório em relação ao primeiro e (iv) um dano efetivo ou em potencial ${ }^{61}$.

\subsubsection{O factum proprium}

O factum proprium é aquele ato inicial praticado. A partir dele, são geradas expectativas que, uma vez aderidas por terceiros, ensejam a possibilidade de vedação de comportamentos contraditórios. Mas, para que ele possa ser identificado como apto a gerar expectativas, algumas ressalvas são feitas pela doutrina.

Em primeiro lugar, o factum proprium deve corresponder a um comportamento humano, excluindo-se os fatos naturais que independam da vontade - afinal, inexiste confiança gerada por um ato involuntário da natureza, além de inexistir possível responsável. Contudo, não se trata de comportamento inserido na classificação dos atos jurídicos em sentido estrito ou negócio jurídico, que, por definição, têm seus efeitos previstos em lei ou estipulados pela vontade das partes, tendo sua vinculatividade derivada

\footnotetext{
${ }^{61}$ ANDERSON SCHREIBER, A proibição de comportamento contraditório, p. 132. Em sentido bastante similar,
} cf. JUDiTh MARTINS-COSTA, A boa-fé no direito privado, p. 471. 
diretamente do direito positivo e, portanto, não carecem de aplicação da teoria do nemo potest venire contra factum proprium para afirmarem sua oponibilidade perante terceiros.

Em outras palavras, caso o factum proprium praticado represente um ato jurídico do qual decorrem deveres impostos pelo ordenamento, eventual contradição a esses deveres configura uma ilicitude propriamente dita, de modo que o ato contraditório será obstado por afrontar o sistema jurídico, dispensando-se a invocação da teoria da proibição de atos contraditórios.

Caso ele fosse correspondente à manifestação de vontade da qual resultou a celebração de um negócio jurídico, eventual contradição representaria um inadimplemento contratual, sem a necessidade de se falar em venire contra factum proprium ${ }^{62}$. Daí se afirmar que "o factum proprium não consiste em ato jurídico, no sentido tradicional; passa a produzir efeitos jurídicos somente por força da necessidade de tutelar a confiança legítima depositada por outrem. Em síntese, não é jurídico, torna-se jurídico"63.

O factum proprium apresenta em um primeiro momento uma importância fática decorrente das expectativas que dele emanam. Mas, tratando-se de conduta lícita, ele não apresenta per si relevância jurídica para fins de repreensão da conduta, o que se torna necessário apenas se constatados todos os demais elementos para a configuração do venire, ou seja, após identificado um segundo comportamento, a contradição entre ambos, a confiança objetivamente depositada pelo factum proprium e um dano, ainda que em caráter potencial.

Em resumo, o factum proprium não deve se confundir com um ato jurídico cujas consequências já são vinculativas em lei, já que a contradição a essa vinculatividade

\footnotetext{
${ }^{62}$ Especificamente sobre os negócios jurídicos, DÍEZ-PICAZO afasta a tendência jurisprudencial na Espanha de considerar venire contra factum proprium o inadimplemento do negócio jurídico: "Como se ha dicho muy agudamente entre nosostros, aunque la doctrina de los actos propios viene siendo confundida sistemáticamente con la doctrina de los efectos del consentimiento o declaración de voluntad, es claro, sin embargo, que es esta última doctrina y no la primera la que explica la vinculación del sujeto a sus actos jurídicos. El que yo no pueda, se añade, retirarme unilateralmente de un contrato no es una consecuencia de la doctrina de los actos propios, sino obviamente una consecuencia, la primera del contrato" (DíEZ-PICAZO, La doctrina de los propios actos, p. 148).

${ }^{63}$ ANDERSON SCHREIBER, A proibição de comportamento contraditório, p. 134. Nesse mesmo sentido são as afirmações de MENEZES CORDEIRO: "Por outro lado, afasta-se, também, à partida, a hipótese de o factum proprium, por integrar os postulados da autonomia privada, surgir como acto jurídico que vincule o autor em termos de o segundo comportamento representar uma violação desse dever específico; accionar-se-iam, então, os pressupostos da chamada responsabilidade obrigacional e não os do exercício inadmissível de posições jurídicas" (Da boa-fé no Direito Civil, p. 746).
} 
representa um ilícito a ser disciplinado pela responsabilidade civil, dispensando-se a invocação da teoria dos atos próprios ${ }^{64}$.

Alguns autores destacam a necessária relevância jurídica como requisito do factum proprium, excluindo a possibilidade de meras opiniões ou externalização de intenções configurarem essa conduta inicial vinculativa ${ }^{65}$. Entretanto, essa ressalva é desnecessária $^{66}$, na medida em que o importante é o factum proprium ser capaz de gerar confiança em terceiros; assim, se uma intenção externada não foi capaz, diante do contexto do caso concreto, de produzir tais expectativas, não estará configurado o factum proprium; de outro lado, sempre que dos fatos for possível se depreender a confiança, o fato próprio qualifica-se como um relevante jurídico.

Por fim, indaga-se quanto à possibilidade de o factum proprium ser, em verdade, uma omissão, ou seja, se a ausência de qualquer comportamento é capaz de gerar legítimas expectativas em terceiros, a ponto de não mais poderem ser contrariadas por condutas comissivas ulteriores.

De uma maneira geral, conclui a doutrina pela possibilidade de a omissão gerar expectativas $^{67}$. A inatividade, em meio a determinadas circunstâncias, emite em outrem a confiança de que o ato não mais será praticado, de modo que sua prática posterior passa a representar uma contradição que afronta a confiança existente e decorrente da passividade.

Todavia, a maior parte da doutrina se refere a esse fenômeno da contradição à confiança gerada pela omissão não como hipótese de venire, mas sim como de suppressio, nome latino dado por MENEZES CORDEIRO ao fenômeno a que os alemães denominaram

\footnotetext{
${ }^{64}$ Para aclarar as ideias expostas, destacam-se os exemplos dados por ANDERSON SCHREIBER: "São exemplos de factum proprium o comportamento concreto de uma das partes à margem das disposições contratuais, a sustentação de um certo sentido na interpretação de uma norma qualquer, as negociações preliminares a um contrato e qualquer outra conduta que não seja em si declarada vinculante pelo ordenamento jurídico positivo. Por outro lado, a celebração de um contrato ou a emissão de uma promessa de recompensa não configuram tecnicamente um factum proprium, porque são já considerados vinculantes pelo direito positivo." (A proibição de comportamento contraditório, p. 135).

65 Alejandro Borda, La doctrina de los actos propios, p. 68.

${ }^{66}$ ANDERSON SCHREIBER, A proibição de comportamento contraditório, p. 137.

${ }^{67}$ Corroborando tal afirmação: "Normalmente, la primera declaración vinculante se emitirá mediante un acto, aunque también el silencio puede obligar a un sujeto y exigirle luego coherencia con esa pasividad" (MARCElo Mesa e CARlos VIDE, La doctrina de los actos propios, p. 113). E ainda: "El silencio provoca una manifestación de voluntad que, en sus efectos, no difiere de una manifestación expresa de voluntad y, por lo tanto, ambas tienen la misma consecuencia: la inadmissibilidad de contradecir la manifestación anterior en aras de proteger los interesses depositados en ésta." (ALEJANDRO BORDA, La teoria de los actos propios, p. 96). No mesmo sentido, $f f$. JoRGE PEYRANO, La doctrina de los propios actos en el ámbito del procedimiento civil, p. 231.
} 
Verwirkung $^{68}$, e que é comumente tratado de maneira autônoma com relação ao venire, destacando-se a coincidência parcial entre as figuras por ambas representarem institutos que visam a obstar a afronta à boa-fé objetiva.

Assim, conceitua-se a suppressio pela "situação do direito que, não tendo sido, em certas circunstâncias, exercido durante um determinado lapso de tempo, não possa mais sê-lo por, de outra forma, se contrariar a boa fé" ${ }^{69}$. A autonomia do venire contra factum proprium com relação à suppressio justifica-se, para alguns, porque nesta o fator tempo adquire maior relevância ${ }^{70}$, sendo imprescindível que a omissão tenha se dado por um intervalo de tempo considerável, a ponto de se tornar pouco crível a qualquer pessoa que aquele direito ainda seria exercido.

Entretanto, o apego ao fator tempo parece ignorar o escopo principal de ambas as figuras, que é a proteção da confiança. Considerando essa coincidência de escopos, temse que o tempo, em verdade, é comumente observado em maior extensão nos casos denominados de suppressio porque, naturalmente, a confiança decorrente do não exercício de um direito depende de uma apreciação do contexto fático mais rigorosa, a fim de se evitar que qualquer omissão, uma vez contrariada por ato posterior, já configure realidade afrontadora da boa-fé.

Em outras palavras, porque originada de uma omissão, é natural que nos casos de suppressio seja identificado um lapso temporal considerável. Mas, além do fato de comumente as condutas comissivas do venire também serem separadas por um intervalo de tempo, o fato é que o tempo não representa um valor em si, mas apenas um elemento instrumental para verificação da confiança emanada da ação ou omissão, conforme o caso concreto $^{71}$. Tanto isso é verdade que somente a necessária verificação da confiança

\footnotetext{
${ }^{68}$ ANDERSON SCHREIBER, A proibição de comportamento contraditório, p. 185; MARCELO DICKSTEIN, As funções da boa-fé objetiva e a proibição de comportamento contraditório, p. 100; MARCELO MESA e CARLOS VIDE, La doctrina de los actos propios, p. 84.

${ }^{69}$ Menezes Cordeiro, Da boa fé no Direito Civil, p. 797. A doutrina argentina e espanhola identificam o mesmo fenômeno também pelo nome de "retraso desleal", $c f$. MARCELO MESA e CARLOS VIDE, La doctrina de los actos propios, p. 82.

${ }^{70}$ Menezes Cordeiro, Da boa fé no Direito Civil, pp. 808-810, oportunidade em que o autor expõe a divergência doutrinária entre os alemães quanto à possibilidade ou não de a suppressio ser figura inserida no conceito de venire. A valorização do tempo como divisor de águas entre os institutos para alguns autores é também constatada por ANDERSON SCHREIBER, A proibição de comportamento contraditório, p. 189. Assim defende, v.g. PAUlo MOTA PINTO, Sobre a probição do comportamento contraditório no direito civil, p. 171172.

${ }^{71}$ ANDERSON SCHREIBER, A proibição de comportamento contraditório, pp. 188-190. Esclarecedoras as palavras de MENEZES CORDEIRO: "Factum proprium pode, afinal, ser qualquer eventualidade que, constituindo a base da imputação, a uma pessoa, de certas consequências, lhe seja própria. A não actuação de um direito subjectivo é, pois, facto próprio do seu titular. A realidade social da suppressio, que o Direito
} 
rompida, para configuração da suppressio, é que justifica sua autonomia com relação a figuras como prescrição e decadência ${ }^{72}$.

Outra possível distinção entre suppressio e venire está em seus efeitos: para alguns autores, pela suppressio haveria verdadeira extinção do direito preexistente, o que significaria impossibilidade de novamente praticá-lo; pelo venire, por sua vez, haveria apenas a ineficácia do direito enquanto perdurar a situação de desconfiança, mas sem que haja perda do direito propriamente dito ${ }^{73}$.

Entretanto, parece-nos mais acertado afirmar que essa diferença é inexistente e, ainda que existente fosse, seria secundária. Inexistente porque, em verdade, a suppressio não extingue o direito preexistente e, tal como ocorre com o venire, é ineficaz enquanto perdurar a situação de proteção de expectativas ${ }^{74}$. Como exemplo, pode-se imaginar um contrato de locação que preveja multa moratória progressiva conforme os dias de atraso, porém costumeiramente o locatário pagava atrasado e o locador nunca cobrara a multa. Configuraria suppressio o exercício repentino desse direito que jamais fora exercido, porém, após a devida notificação de que tal cláusula passaria a ser cumprida, e conferido um lapso temporal suficiente para o locatário ajustar as suas expectativas com relação a esse ponto, nada impediria que o direito fosse exercido pelo locador.

Ainda para os que assim não pensem, tal diferenciação seria secundária porquanto instrumental à tutela da confiança emitida. Assim, se pela suppressio foi gerada a confiança de que uma situação jurídica não mais seria exercida, a maneira mais eficaz de se tutelar a confiança é justamente vedando o exercício desse direito - o que nem sempre será possível, conforme item 3.3. infra. Da mesma maneira, pelo venire, o objetivo é obstar a prática do comportamento contraditório para tutelar a confiança frustrada e, somente em

procura orientar, está na ruptura das expectativas de continuidade da auto-representação praticada pela pessoa que, tendo criado, no espaço jurídico, uma imagem de não exercício, rompe, de súbito, o estado gerado. É precisamente o que se viu ocorrer no venire contra factum proprium. Norteada a questão nestes termos, o tempo, requerido pelo funcionar da suppressio, ganha uma inclinação diferente. Em qualquer manifestação de venire contra factum proprium existe, por mínimo que seja, um lapso entre dois comportamentos do sujeito. Na suppressio, porém, o tempo tem uma segunda projeção, do maior relevo: expectativas sociais de que essa auto-representação se mantém. O que é dizer: o decurso do tempo é a expressão da inactividade traduzindo, como tal, o factum proprium. A suppressio pode, pois, considerar-se uma forma de proscrever os comportamentos contraditórios" (Da boa fé no Direito Civil, p. 814).

${ }^{72}$ FERNANDO NORONHA, O direito dos contratos e seus princípios fundamentais, p. 186.

${ }^{73}$ FERNANDO NORONHA, O direito dos contratos e seus princípios fundamentais, pp.184-185.

${ }^{74}$ Vale apontar a existência da surrectio, que nada mais é do que a suppressio, vista sob o ângulo do terceiro cuja confiança é protegida. (CLAUdIO GODOY, Função social do contrato, p. 92). Para FERNANDO NORONHA: "Esta figura da perda do direito por protraimento desleal de seu exercício poderá ser encarada não do ponto de vista da pessoa que deixou de exercer o direito, mas do daquela que resultou beneficiada. É o que faz Menezes Cordeiro, que sustenta ser a suppressio (como designa a figura) apenas subproduto de outro fenômeno, que designa de surrectio" ( $O$ direito dos contratos e seus princípios fundamentais, p. 187). 
caso de reajuste de expectativas, a situação jurídica que representa a contradição igualmente poderá ser exercida, tal como ocorre na suppressio.

Em razão disso, optamos pela corrente que afirma ser a suppressio apenas uma modalidade de venire contra factum proprium, qual seja, a de vedação de comportamento contraditório à confiança originada de uma conduta omissiva ${ }^{75}$.

\subsubsection{A confiança}

Com relação ao segundo pressuposto, é preciso que o factum proprium desperte legítima confiança em outrem, pois é justamente essa confiança o objeto de proteção que justifica a aplicação da teoria da vedação a comportamentos contraditórios ${ }^{76}$.

Sem hesitação afirma-se, portanto, que a confiança é o requisito mais relevante para o estudo do fenômeno, vez que é o elemento capaz de diferençar o motivo por que algumas contradições são admitidas pelo ordenamento, ao passo que outras são vedadas: somente aquela contradição responsável por ferir expectativas geradas é que é objeto de reprimenda.

Isso significa dizer que a contradição, por si só, não é vedada a priori, sendo lícito que as pessoas mudem de opinião, sob pena de se mitigar por demais o princípio da autonomia da vontade ${ }^{77}$. Somente quando essa contradição passa a significar ruptura de expectativas legitimamente consideradas a partir do factum proprium, surge espaço para a

\footnotetext{
75 A mesma conclusão é extraída de ANDERSON SCHREIBER, A proibição de comportamento contraditório, pp. 188, bem como de ALDEMIRO REZENDE DANTOS JÚNIOR, Teoria dos atos próprios no princípio da boafé, p. 395. FERNANDO NORONHA, apesar de ressaltar a existência de especifidades das figuras, aduz que a suppressio, ao lado do abuso de nulidades, são hipóteses de comportamentos contraditórios que "cabem dentro da figura mais ampla, o venire" ( $O$ direito dos contratos e seus princípios fundamentais, p. 183), tal como afirma FRANZ WIEACKER, El principio general de la buena fé, p. 62.

${ }^{76}$ MANUEL ANTÓNIO CARNEIRO DA FRADA, com razão, afirma: "Pensamos que a razão de ser material da relevância da contraditoriedade da actuação radica essencialmente na eficácia geradora de confiança do comportamento do sujeito. As expectativas suscitadas pelo seu agir anterior explicam que um comportamento posterior seu possa contradizê-las em termos de suscitar uma intervenção da ordem jurídica para tutelar a posição do confiante. Não é aquela oposição que em si mesma (na sua formalidade) o justifica - sublinhe-se -, mas a confiança depositada num determinado proceder futuro do agente tendo em conta uma conduta sua precedente" (Teoria da confiança e responsabilidade civil, pp. 411-413).

${ }^{77}$ Menezes CordeIro, Da boa fé no Direito Civil, p. 750; MARCElo MESA e CARLOS Vide, La doctrina de los actos propios, p. 171.
} 
incidência do venire ${ }^{78}$. A contradição passa a ser vista apenas como um instrumento para a proteção da confiança, e não um valor em si mesmo ${ }^{79}$.

A relação entre o venire e a confiança só foi firmada pela doutrina recentemente, e a partir daí o estudo retomou seu espaço nas discussões modernas. Até então, o instituto era desprestigiado por ter aplicabilidade muito restrita, já que as regras eram elas mesmas contraditórias quando se buscava um princípio geral de repúdio à contradição. Somente quando se passou a considerar como objetivo da vedação de comportamentos contraditórios a tutela da confiança, o instituto passou a ser reestruturado sob uma ótica distinta, capaz de conferir-lhe tanto uma utilidade prática que não pode ser ignorada quanto uma base teórica consistente.

MENEZES CORDEIRO entende ser o venire contra factum proprium uma expressão da confiança. Essa, em verdade, é o "critério de decisão" que faltava ser delimitado pela doutrina para viabilizar a aplicabilidade do instituto e não o confundir com a tentativa de vedar a contradição em qualquer hipótese ${ }^{80}$.

A confiança é considerada objetivamente ${ }^{81}$, ou seja, ela será identificável nos casos concretos por meio de indícios de sua existência, que transcenderão o estado psíquico daquele que pleiteia a proteção por meio da aplicação da vedação a comportamentos contraditórios ${ }^{82}$.

Para alguns autores, apesar de a identificação da confiança ser feita por meio de uma análise objetiva, há um momento de subjetividade que diz respeito à adesão de

\footnotetext{
78 Judith Martins-Costa, A boa-fé no direito privado, p. 471; Marcelo Mesa e Carlos Vide, La doctrina de los actos propios, p. 91; MARCELO DICKSTEIN, As funções da boa-fé objetiva e a proibição de comportamento contraditório, p. 93; ALDEMIRO REZENDE DANTAS JÚNIOR, Teoria dos atos próprios no princípio da boa fé, p. 293. Sobre o tema, MENEZES CORDEIRO afirma que "A existência de princípios contraditórios - neste caso, proibição de venire contra factum proprium e permissão de contraditoriedade não deve confundir: é conquista da Ciência do Direito moderno a possibilidade de oposições desse tipo, sem ruptura do sistema e sem quebra de validade para nenhum dos princípios em presença. Fica em aberto a oportunidade de sua aplicação, em cada caso concreto". (Da boa fé no Direito Civil, p. 756).

${ }^{79}$ ANDERSON SCHREIBER, A proibição de comportamento contraditório, p. 101.

${ }^{80}$ MENEZES CORDEIRO, Da boa-fé no Direito Civil, p. 756.

${ }^{81}$ ANDERSON SHCREIBER, A proibição de comportamento contraditório, p. 141; OSVALDO GOZAínI, La conducta en el proceso, p. 195.

${ }^{82}$ A casuística será responsável por delimitar como pode ser aferida essa confiança a ser objetivamente observada. No entanto, a doutrina já se encarrega de exemplificar alguns modos de aferição, para melhor elucidação do tema. Assim, é presumível a adesão à confiança quando presente, por exemplo: "(i) a efetivação de gastos e despesas motivadas pelo factum proprium; (ii) a divulgação pública das expectativas depositadas, (iii) a adoção de medidas ou a abstenção de atos com base no comportamento inicial, (iv) o grau elevado de sua repercussão exterior, (v) a ausência de qualquer sugestão de uma futura mudança de comportamento, e assim por diante" (ANDERSON SCHREIBER, A proibição de comportamento contraditório, pp. 141-142).
} 
terceiros à confiança despertada pelo factum proprium $^{83}$. Sem essa adesão, desnecessária qualquer proteção a terceiros ${ }^{84}$.

Certamente, ainda que existente uma situação objetiva geradora de confiança, é preciso que haja adesão do confiante, pois, sem ela, nenhuma tutela jurídica tem razão de ser, ou seja, mesmo havendo uma expectativa gerada por um ato, se ninguém confiou nela, não há motivos para a proteção jurídica.

Todavia, essa confiança depositada no factum proprium tem também possibilidade objetiva de aferição, baseando-se na análise do prejuízo gerado àquele que se diz aderente. Dessa forma, a prova da adesão à confiança do ponto de vista subjetivo é desnecessária, vez que pressuposto quando da verificação do dano, quarto requisito a ser demonstrado ${ }^{85}$.

Em outras palavras, não se nega a existência de um momento de subjetividade referente à efetiva adesão à confiança gerada. Contudo, essa adesão ocorrida no íntimo do confiante possui manifestações externas capazes de demonstrá-la objetivamente, por meio dos prejuízos por ele arcados após a ocorrência do primeiro comportamento gerador de expectativas, bem como das alterações de comportamento que indiquem a adesão à confiança. Em consequência, reafirma-se a ideia de que todos os pressupostos necessários para aplicação do venire são objetivamente observáveis.

É necessário que a confiança seja legítima, ou seja, baseada em situação na qual um homem médio passaria a ver naquele primeiro comportamento a impossibilidade

\footnotetext{
${ }^{83}$ É o que afirma CAMILA GONÇALVES: "A jurisprudência fornece critérios para a concretização da confiança que se protege pela vedação do venire, quais sejam: a atuação de um fato gerador da confiança; e a adesão do confiante a esse fato, desenvolvendo atividade posterior, com base nessa confiança, de tal modo que a supressão do fato implique iniquidade sem remédio. Assim, verifica-se um elemento objetivo, consistente na manifestação de vontade suficiente, para convencer uma pessoa normal; e um elemento subjetivo, correspondente à adesão ao fato gerador da confiança, além do desenvolvimento de atividade pelo confiante" (Princípio da boa-fé, p. 47). A autora partiu da reflexão feita por MENEZES CORDEIRO: "Requer-se, porém, ainda um elemento subjetivo: o de que o confiante adira, na realidade, ao facto gerador de confiança. Reparese, que bem poderia suceder, não obstante a presença de elementos objectivos suficientes para justificar a protecção da confiança, que o beneficiário em potência, por razões específicas, não tivesse, de facto, confiado na situação jurídica que se oferecia. Não cabe, então, conceder-lhe a protecção jurídica." (Da boa$f e ́$, p. 759). No mesmo sentido, $c f$. AlEJANDRO BORDA, La teoria de los actos propios, p. 60.

${ }^{84}$ JORGE PEYRANO, La doctrina de los propios actos en el ámbito del procedimiento civil, p. 231.

${ }^{85}$ Essa é a solução dada por MENEZES CORDEIRO, que, ao admitir esse elemento subjetivo, afirma que: "O investimento de confiança, por fim, pode ser sinteticamente explicitado como a necessidade de, em consequência do factum proprium a que aderiu, o confiante ter desenvolvido uma actividade tal que o regresso à situação anterior, não estando vedado de modo específico, seja impossível, em termos de justiça". (Da boa fé no Direito Civil, p. 759). Em outras palavras, o autor afirma que a adesão à confiança é identificável pelo esforço objetivo do confiante, que gera uma situação que não deve ser revertida, sob pena de o ordenamento ser condescendente com a frustração de expectativas legítimas.
} 
de posterior contradição, tamanha a confiança gerada ${ }^{86}$. Por isso, basta um aviso sobre a possibilidade de mudança de comportamento para que não seja possível considerar a confiança como legítima, como ocorre, por exemplo, em hipótese na qual, durante uma entrevista de emprego, o empregador afirma que, até aquele momento, o candidato já estaria contratado, mas ressalta o fato de haver mais entrevistas a serem feitas; neste caso, a simples ressalva impede que, se dispensado, o candidato sinta-se de alguma forma lesado, pois a possibilidade de alteração do comportamento foi desde logo alertada.

\subsubsection{O comportamento contraditório e o dano}

Existente um primeiro comportamento gerador de confiança legítima e objetivamente aferida, o próximo requisito para configuração da teoria é a contradição, concretizada por um novo ato em oposição ao primeiro.

Mais uma vez, a contradição manifesta-se por meio de um comportamento objetivo, sendo irrelevante o íntimo do agente, sua intenção de contradizer-se ou não ${ }^{87}$. Adotada conduta diversa, capaz de ser identificada como contraditória em relação à primeira de modo a ferir expectativas de terceiros, cogita-se a aplicação do nemo potest venire contra factum proprium.

Fundamental ressaltar, sobre esse terceiro pressuposto, que se trata de uma conduta lícita tal como o factum proprium, ou seja, caso fosse analisada isoladamente, não seria contrária aos ditames do ordenamento jurídico e não mereceria qualquer represália. Afinal, tratando-se de conduta ilícita, o próprio ordenamento se encarrega de reprimi-la, vedá-la sem que seja necessária qualquer referência à teoria do venire $e^{88}$.

\footnotetext{
${ }^{86}$ Menezes CoRdeIRo, Da boa fé no Direito Civil, pp. 758-759. Vale pensarmos que a noção de homem médio varia conforme o caso concreto, conforme as circunstâncias pessoais de cada sujeito, o que pode influenciar na identificação daconfiança legítima. Como exemplo, a confiança gerada perante um consumidor comum pode não ser a mesma gerada em face de um advogado.

87 DíEZ-PICAZO, La doctrina de los propios actos, p. 189. FRANZ WIEACKER afirma que o venire "no presupone necesariamente el que, de mala fe o con negligencia cupable, se cree una expectativa en la otra parte. La exigencia de confianza no es obligación de veracidad subjetiva, sino - como en la moderna teoría de la validez de la declaración de voluntad - el no separarse del valor de significación que a la propia conducta puede serle atribuido por la otra parte" (El principio general de la buena fé, p. 61). No mesmo sentido, $c f$. FERNANDO NORONHA, $O$ direito dos contratos e seus princípios fundamentais, p. 184.

${ }^{88}$ ANDERSON SCHREIBER, A proibição de comportamento contraditório, pp. 145-146; ALEJANDRO BORDA, La teoria de los actos propios, p. 75. MANUEL ANTÓNIO CARNEIRO DA FRADA bem explica a relação entre factum proprium e comportamento contraditório, bem com a necessária licitude e interligação entre eles: "Preliminarmente, importa apontar que a autonomia do venire implica uma específica relevância da
} 
É por esse motivo, inclusive, que se afirma o caráter subsidiário do instituto, aplicável somente nos casos em que não houver previsão legal de permissão ou vedação de comportamento contraditório ${ }^{89}$.

Esse segundo comportamento, conforme se afirmou, deve contradizer o primeiro, o que significa dizer que ele deve ir de encontro à confiança gerada pelo factum proprium. Para tanto, alguns autores entendem ser necessário um lapso de tempo entre as condutas contraditórias, pois somente verificado esse intervalo seria possível vislumbrar uma confiança gerada perante terceiros ${ }^{90}$. Alguns afirmam, ainda, que além do lapso, é necessário haver uma periodicidade do factum proprium, pois somente assim a confiança seria considerada legítima.

É certo que, quando se observa uma conduta por muito tempo reiterada, a adoção de comportamento diverso e contrário ao que vinha sendo praticado permite fácil identificação da quebra da confiança, motivo pelo qual a aplicação do venire é quase intuitiva $^{91}$. Já ressaltamos, ainda, que quando o factum proprium é uma omissão, o tempo passa a adquirir importância quase que essencial para que a inércia, assim mantida por um longo período, permita gerar em terceiros a confiança do não mais exercício daquele direito.

contraditoriedade entre comportamento antecedente e subsequente. O juízo do venire apenas é formulável ex post, no termo e como resultado de uma comparação entre condutas que se sucederam mas que não são harmónicas entre si. Somente o comportamento posterior do sujeito consuma o venire. Embora este não se absorva naquele. De facto, per se tomada, a conduta ulterior do sujeito apresenta-se necessariamente como lícita e conforme com a ordem jurídica. Caso contrário, ela apenas traduziria uma situação vulgar de falta de direito ou de desrespeito de uma vinculação que comprimiria a esfera de liberdade do sujeito. Nenhum papel restaria então ao venire" (Teoria da confiança e responsabilidade civil, pp. 409-410).

89 "A proibição do comportamento contraditório aplica-se, então, primordialmente àqueles atos que não são originariamente vinculantes e sobre cuja possibilidade de contradição o legislador não se tenha manifestado expressamente. Sua aplicação é, por esta razão, dita muitas vezes subsidiária, porque restrita àquele campo em que não há incidência direta de norma específica autorizando ou proibindo o comportamento incoerente. $\mathrm{O}$ termo subsidiário não deve, porém, iludir: a esfera de atuação do nemo potest venire contra factum proprium é riquíssima como revelará oportunamente o estudo dos casos concretos."(ANDERSON SCHREIBER, A proibição de comportamento contraditório, p. 100). Ainda sobre o caráter subsidiário do venire, $c f$. JORGE PEYRANO, La doctrina de los propios actos en el ámbito del procedimiento civil, p. 233; MARCELO DICKSTEIN, As funções da boa-fé objetiva e a proibição de comportamento contraditório, p. 94; MARCELO MeSA e CARLOS VIDE, La doctrina de los actos propios, p. 180; ALEJANDRO BORDA, La teoria de los actos propios, p. 90; OsVALDO GoZAínI, La conducta en el proceso, pp. 201-202.

${ }_{90}$ LuCIANO CAMARGO, Figuras parcelares da boa-fé objetiva e venire contra factum proprium, p. 261; ALEJANDRO BORDA, La teoria de los actos propios, pp. 72-73.

${ }^{91}$ Nesse sentido, ilustrativo o exemplo exposto por LUCIANO CAMARGO e retirado de um julgado do SUPERIOR TRIBUNAL DE JUSTIÇA: "Trata-se de um caso de uma mulher que não assina o contrato de compromisso de compra e venda, admite sua lide em juízo e não impugna o contrato por dezessete anos, vindo depois a se recusar a fornecer a escritura. Neste caso fica clara a importância do venire como figura apta a criar direitos e deveres para as partes" (Figuras parcelares da boa-fé objetiva e venire contra factum proprium, p. 273). É o caso enfrentado no STJ, $4^{\text {a }}$ Turma, Resp 95.539-SP, rel. MIN. RUY ROSADO DE AGUIAR, v.u., j. 03.09.1996, DJU 14.10.1996, p. 39015. 
Contudo, o lapso de tempo e a periodicidade não são elementos essenciais, pois, mesmo sem eles, é possível identificar existência de uma confiança legítima que mereça ser tutelada. Assim, ainda que os comportamentos contraditórios sejam simultâneos, se o primeiro deles for capaz de gerar expectativas legítimas a outrem, há a possibilidade de aplicação do venire ${ }^{92}$. O importante, portanto, é o comportamento inicial e a posterior contradição terem rompido expectativas geradas, sendo o tempo apenas um fator instrumental para se averiguar, em cada caso concreto, a existência dessa confiança.

Ainda quanto à contradição e o fator temporal, parte da doutrina enfrenta o tema da possibilidade de reconsideração imediata do factum proprium, e se isso teria o condão de afastar a aplicabilidade do venire. O tema, mais uma vez, é solucionado a partir da análise casuística, buscando-se identificar se no intervalo de tempo entre o exercício do factum proprium e a retratação, houve expectativas geradas e aderidas por terceiros. Se a resposta for positiva, ainda que haja retratação, a confiança produzida deve ser tutela pela vedação de comportamentos contraditórios ${ }^{93}$.

Como quarto requisito para configuração de situação que requer a vedação a comportamentos contraditórios, tem-se o dano, efetivo ou potencial. Nem sempre esse requisito é apontado pela doutrina ${ }^{94}$. Todavia, mais acertado é destacá-lo como pressuposto independente, afinal, na reparação do dano ou na sua prevenção é que reside a utilidade no Direito Privado de se vedar comportamentos contraditórios que quebrem expectativas depositadas anteriormente.

Cumpre ressaltar, sobre o dano, que ele pode tanto já ter se verificado, como ser potencial, bem como que não precisa ter necessariamente caráter patrimonial. A doutrina aponta que a simples quebra de expectativa não gera um dano moral propriamente dito, mas dela podem surgir danos morais, conforme o caso concreto ${ }^{95}$.

\footnotetext{
92 O exemplo dado por ANDERSON SCHREIBER revela essa possibilidade: "Imagine-se, a título de exemplo, que a Administração Pública proceda simultaneamente à licitação para alienação de um terreno, e à propositura de uma ação declaratória de nulidade do processo licitatório. Ainda que ambos os atos - a abertura da licitação e a propositura da ação judicial - tenham sido praticados simultaneamente, resta evidente que o particular, que tomou conhecimento da licitação em um primeiro momento, mas só muito depois, quiçá após a efetiva transferência do terreno, veio a ser informado da ação declaratória de nulidade, é titular de legítima confiança" (A proibição de comportamento contraditório, p. 151).

${ }^{93}$ DíEZ-PICAZO, La doctrina de los propios actos, p. 216.

94 Sem destaque do dano, $c f$. LuCIANO DE CAMARGO PENTEADO, Figuras parcelares da boa-fé objetiva e venire contra factum proprium, p. 262; JORGE PEYRANO, La doctrina de los propios actos en el ámbito del procedimiento civil, pp. 230-234; ALEJANDRO BORDA, La teoria de los actos propios, p. 67.

95 ANDERSON SCHREIBER, A proibição de comportamento contraditório, pp. 152-154.
} 
3.1.4. Observações finais: sujeitos ativo e passivo da contradição, não cumulatividade dos pressupostos e análise valorativa

Por fim, é preciso enfrentar a discussão doutrinária quanto à necessidade ou não de a contradição ser praticada por um mesmo sujeito e se também deve gerar confiança em face de uma mesma pessoa.

No que se refere ao sujeito passivo, frente ao qual se praticam os atos contraditórios, entende-se que, na sociedade contemporânea, em que os meios de divulgação comercial possuem grande alcance, é possível que a confiança gerada a partir de comportamentos do agente em face de diferentes pessoas seja considerada por alguém que ainda não teve contato direito com ele, o que é comum no contexto de relações consumeristas.

O exemplo dado por ANDERSON SCHREIBER é a hipótese segundo a qual um consumidor é atraído a comprar um veículo de determinado fabricante pela fama que a empresa possui de sempre fornecer substituição de peças que apresentem defeitos no prazo de dois anos. Se, porventura, o automóvel apresentar um defeito e a fabricante recusar-se a consertá-lo gratuitamente, porque especificamente no contrato firmado com este consumidor a garantia é de apenas um ano, certamente haverá confiança rompida e que fora gerada com base em comportamento anterior da empresa perante outros compradores $^{96}$. Assim, tendo em vista o enfoque dado à tutela da confiança, basta que ela esteja presente para que, uma vez rompida, seja necessário protegê-la.

E isso vale também para situação em que diferentes sujeitos ativos entrem em contradição, desde que eles representem um mesmo centro de interesses. O tema não é pacífico, pois muitos defendem que, não obstante a possibilidade de variedade quanto ao sujeito passivo, faz-se necessária a coincidência entre o sujeito ativo que praticou o factum proprium e aquele que exerceu ato posterior contraditório ${ }^{97}$, ou ainda, que os atos sejam juridicamente imputáveis a uma mesma pessoa ${ }^{98}$.

Todavia, mais acertada a admissão da ideia de que a confiança possa ser originada por sujeitos fisicamente e até juridicamente distintos, mas que componham o

\footnotetext{
${ }^{96}$ ANDERSON SCHREIBER, A proibição de comportamento contraditório, p. 156.

${ }^{97}$ MARCELO MESA e CARLOS VIDE, La doctrina de los actos propios, p. 122.

${ }^{98}$ DíEZ-PICAZO, La doctrina de los propios actos, p. 232.
} 
mesmo polo de interesses ${ }^{99}$. É o que ocorre, por exemplo, com a contradição provocada por atos da Administração Pública, ainda que praticados por órgãos distintos; ou ainda, em atos contraditórios praticados por empresas diferentes, porém integrantes de um mesmo controle societário $^{100}$.

Ainda sobre os pressupostos, há de se ressaltar que eles não são cumulativos, necessariamente. É possível que, frente a um caso concreto, tamanha seja a intensidade de um deles que a ausência de outro não impeça a configuração do venire ${ }^{101}$.

Em complementação, a análise dos pressupostos demonstra o fato de o instituto do venire contra factum proprium depender de um juízo valorativo para sua aplicabilidade. Isso porque, frente à situação concreta, será fundamental identificar a presença da confiança legítima posteriormente frustrada e merecedora de tutela. Essa identificação, por sua vez, dependerá das circunstâncias fáticas apresentadas, o que releva o caráter axiológico do instituto, destinado à proteção do valor confiança, cuja presença se verifica por meio de um exame valorativo do caso ${ }^{102}$.

Apesar de posições divergentes, esses são os pressupostos consolidados na grande maioria dos recentes estudos sobre o venire contra factum proprium. O problema, portanto, não reside na identificação do instituto, mas principalmente na definição de qual o seu fundamento jurídico no ordenamento brasileiro, e, como consequência, qual o seu âmbito de atuação.

Afinal, é possível falar em um princípio de vedação a comportamentos contraditórios ou trata-se de regra aplicável em casos bastante específicos? Além disso, qual o embasamento legal para aplicação da teoria no Brasil? Seria uma decorrência do

\footnotetext{
99 JORGE PEYRANO, La doctrina de los propios actos en el ámbito del procedimiento civil, p. 232.

100 ANDERSON SCHREIBER, A proibição de comportamento contraditório, pp. 157-162.

101 Menezes CordeIRo, Da boa-fé no Direito Civil, p. 759; JoRge PEYRANO, La doctrina de los propios actos en el ámbito del procedimiento civil, p. 234.

${ }^{102}$ Muitos estudiosos do tema compartilham desse entendimento: "No venire contra factum proprium haveria ainda que efectuar um juízo valorativo sobre a contrariedade ao anterior comportamento, ponderando todos os elementos - cujo 'funcionamento' dependeria das particularidades do caso concreto, podendo a particular intensidade de um ou mais possibilitar a intensidade do outro - para se poder concluir pela 'necessidade ético-jurídica' da proibição da conduta contraditória" (PAUlo MOTA PINTO, Sobre a proibição do comportamento contraditório, p. 145); "Portanto, a categorização do venire contra factum proprium como conduta ilícita só poderá ser feita no caso concreto, ponderando-se as consequências da conduta contraditória na esfera jurídica alheia, tendo em vistas as circunstâncias" (JUDITH MARTINS-COSTA, $A$ ilicitude derivada do exercício contraditório de um direito, p. 125); “Así es, la doctrina de los propios actos, al tomar como baremo indispensable una conducta anterior, requiere presupuestos, con una enorme carga axiológica, tales como la incompatibilidad con la conducta anterior, el carácter de deliberada, jurídicamente relevante y plenamente eficaz, con la consiguiente frustración de la expectativa generada por la parte, com un comportamiento anterior, que varía en el tiempo" (DANIEL FERNANDO ACOSTA, La conducta procesal de las partes como concepto atinente a la prueba, p. 80).
} 
princípio da boa-fé objetiva ou seria espécie de abuso de direito? Muitas dessas perguntas ainda não têm resolução unânime na doutrina civilista e, certamente, solucionar essa polêmica foge à pretensão deste trabalho. Assim, serão expostas as principais ideias sobre o tema com a finalidade apenas de iniciar as reflexões que posteriormente servirão de base para o estudo do venire contra factum proprium no Processo Civil.

\subsection{Base jurídica no ordenamento brasileiro}

Entre todas as pesquisas realizadas, não se teve notícia da existência de qualquer ordenamento jurídico que preveja de maneira positivada e expressa uma regra genérica de vedação a comportamentos contraditórios. Existem situações concretas específicas de vedação à contradição, mas não uma fórmula abstrata a partir da qual se subsumem os casos concretos ${ }^{103}$.

Dentre as causas para essa inexistência de uma regra geral positivada, destacase a dificuldade de conceituar a figura já prevendo as inúmeras possíveis exceções - ou seja, hipóteses em que a contradição é permitida ${ }^{104}-$, bem como o fato de o desenvolvimento da teoria da vedação a comportamentos contraditórios ter sido feita gradualmente, de maneira casuística, a partir da construção jurisprudencial ${ }^{105}$.

Daí a necessidade de buscar outras fontes no sistema a partir das quais se identifique o embasamento jurídico para a incidência do venire. As referências doutrinárias indicam a boa-fé, o abuso do direito e a solidariedade social como fontes possíveis.

\subsubsection{Boa-fé objetiva}

\footnotetext{
${ }^{103}$ Essa ausência de previsão legal expressa se verifica na Argentina: MARCELO MESA e CARLOS VIDE, $L a$ doctrina de los actos propios, p. 105. Em Portugal: MENEZES CoRdEIRO, Da boa fé no Direito Civil, p. 76. No Brasil: ANDERSON SCHREIBER, A proibição de comportamento contraditório, pp.71-74.

104 "Sería impensable, por lo demás, una formulación de la doctrina de los actos propios que pretendiera detallar sus posibles aplicaciones. Además, un listado tal llevaría a un problema adicional: determinar si éste es meramente enunciativo o taxativo, con lo que nada se ganaría con tal intento de agotar su contenido en una norma" (MARCELO MESA e CARLOS VIDE, La doctrina de los actos propios, p. 106).

${ }^{105}$ MARCElo J. LÓPEZ MeSA, La doctrina de los actos propios: esencia y requisitos de aplicación, p. 191.
} 
Ousamos afirmar que a unanimidade da doutrina que estuda o venire contra factum proprium faz menção à relação dessa teoria com o princípio da boa-fée ${ }^{106}$. Alguns autores chegam a sustentar a existência de outras bases jurídicas para fundamentar a incidência do venire, mas nem por isso deixam de ressaltar a sua conexão com a boa-fé, como veremos nos itens seguintes. E até mesmo os que defendem a autonomia do venire, como princípio independente no ordenamento jurídico, apontam a boa-fé como princípio cujo conteúdo é parcialmente coincidente com o da vedação de comportamentos contraditórios. Passemos a estudar, portanto, o conceito de boa-fé, para que se possa compreender sua relação com o venire.

\subsubsection{Boa-fé objetiva como princípio jurídico e como técnica de cláusula geral}

A boa-fé é apontada ora como cláusula geral, ora como princípio, figuras que nem sempre são bem diferenciadas pela doutrina pelo fato de, muitas vezes, aquela conter, em seu enunciado, este, além de a polissemia da palavra "princípio" contribuir para a recorrente confusão ${ }^{107}$.

Assim, entende-se por princípio "aquelas normas que vêm consideradas pelo legislador, pela doutrina, e pela jurisprudência como fundamento (em um dos sentidos desse termo) [qual seja, o de razão que justifica] de um conjunto de outras normas" ${ }^{\text {"108 }}$. O fator essencial para a definição, portanto, está no caráter fundante ${ }^{109}$ do princípio, que

106 Para corroborar a afirmação, tem-se, v.g.: PUIG BRUTAU, Estudios de derecho comparado, p. 102; MARCELO J. LÓPEZ MESA, La doctrina de los actos propios: esencia y requisitos de aplicación, p. 191; JoRge PEYRANO, La doctrina de los propios actos en el ámbito del procedimiento civil, p. 226; ANA I. PIAGGI, Reflexiones sobre dos princípios basilares del derecho: La buena fe y los actos próprios, p. 113; OMAR LUIS DIAZ SOLIME, La buena fe en la estructura procesal, p. 861; OsVALDO GOZAíNI, El principio de la buena fe en el proceso civil, p. 905; DANIEL FERNANDO ACOSTA, La conducta procesal de las partes como concepto atinente a la prueba, p. 79; MARCELO MESA e CARLOS VIDE, La doctrina de los actos propios, p. 91; JUDITH MARTINS-COSTA, A boa-fé no direito privado, p. 471; AlEJANDRO BoRDA, La teoria de los actos propios, p. 53; ANDERSON SCHREIBER, A proibição de comportamento contraditório, p. 95; JOAN PICÓ I JunOY, El principio de la buena fe procesal, p. 126; OSVALDO GOZAÍNI, La conducta en el proceso, p. 182.

107 Judith Martins-Costa, A boa-fé no Direito Privado, p. 316.

108 Judith Martins-Costa, A boa-fé no Direito Privado, p. 316. Optou-se pela adoção da definição de princípio da autora, sabendo-se, porém, que o tema é bastante complexo, e que qualquer definição é passível de inúmeras críticas, as quais não são aprofundadas por não ser esse o tema de enfoque de nossos estudos. Sobre as diferentes concepções de princípio, $c f ., v . g$., HuMBERTO ÁvILA, Teoria dos princípios, pp. 35-40.

${ }^{109}$ A expressão também é de Judith Martins-Costa, A boa-fé no Direito Privado, p. 316, não obstante a ideia de o princípio se caracterizar por fundamentar outras normas ser recorrente na doutrina: "Por nuestra parte, creemos que los principios generales reúnen tres características, a saber: no admiten excepciones, abarcan una generalidad de situaciones, y son la base de una pirámide que no acepta una idea aun más amplia. En estos tres caracteres veremos claramente las diferencias con las reglas de derecho" (ALEJANDRO 
serve de base valorativa para muitas outras normas jurídicas. Outras qualificações dos princípios, como o seu elevado grau de abstração, apesar de corretamente a eles relacionadas, não lhes conferem caráter distintivo perante as outras normas do sistema, que também podem ser abstratas. Frisa-se, assim, o caráter fundante dos princípios ${ }^{110}$.

Nem sempre os princípios estão expressos no ordenamento, podendo também ter previsão apenas implícita, sem que isso lhes altere a qualificação de princípio ${ }^{111}$. Mas sua normativiade é inconteste ${ }^{112}$, buscando-se sua efetividade desde logo, ressalvadas as hipóteses em que ele colidirá com outros valores igualmente relevantes, oportunidade em que haverá a ponderação entre eles à luz do caso concreto.

Essa efetividade vai muito além da função de apenas preencher lacunas no ordenamento jurídico: os princípios, como já afirmamos, têm como função servir de fundamento valorativo para as demais normas jurídicas, agindo, pois, como fator que confere unidade ao sistema jurídico ${ }^{113}$, aplicando-os de maneira direta quando inexistentes normas expressas que os especifiquem, e de maneira indireta quando tais normas existirem. Têm, portanto, funções fundamentadora, interpretativa, supletória e, ainda, restritiva, pois são capazes de impedir a aplicação de uma regra ou outro princípio ${ }^{114}$.

A cláusula geral, por sua vez, é uma técnica legislativa que se opõe à opção casuística, pois, se por meio desta o legislador prevê de maneira exaustiva as fattispecie possíveis, deixando pouco espaço para a atividade do intérprete, naquela a fattispecie é vaga, genérica, com ampla possibilidade de variações interpretativas ${ }^{115}$.

Em verdade, tanto o suporte fático quanto o consequente jurídico são abertos, o que significa dizer que o enquadramento da situação fática à cláusula geral, bem como a imposição das consequências jurídicas garantem amplo espaço de atuação do intérprete do direito $^{116,117}$. Tem, portanto, a vantagem da mobilidade decorrente dessa vagueza do

BORDA, La teoria de los actos propios, p. 55). No mesmo sentido, $c f$., ainda, MARCELO MESA e CARLOS VIDE, La doctrina de los actos propios, pp. 46-47.

110 TERESA NEgREIROS, Fundamentos para uma interpretação constitucional do princípio da boa-fé, pp. 107-115.

${ }^{111}$ Judith Martins-Costa, A boa-fé no Direito Privado, pp. 319-320. Claudio Godoy, Função social do contrato, pp. 97-103.

${ }^{112}$ Robert AleXY, Teoria dos direitos fundamentais, p. 87; ClAUdio GOdOY, Função social do contrato, p. 101.

${ }^{113}$ Claudio Godoy, Função social do contrato, p. 98.

114 TERESA NeGREIROS, Fundamentos para uma intepretação constitucional do princípio da boa-fé, p. 125.

115 Judith MARTINS-COSTA, A boa-fé no direito privado, pp. 296-297.

116 “Cláusula geral é uma espécie de texto normativo, cujo antecedente (hipótese fática) é composto por termos vagos e o consequente (efeito jurídico) é indeterminado. Há, portanto, uma indeterminação legislativa em ambos os extremos da estrutura lógica normativa" (FREDIE DIDIER JR, Fundamentos do princípio da 
suporte fático e consequências jurídicas, atribuindo-se à jurisprudência a função interpretativa, que ocorrerá paulatinamente ${ }^{118}$.

Tal vantagem não é de se menosprezar diante da realidade que vem há muito sendo constatada de maneira quase uníssona na doutrina, qual seja, a da insuficiência da lei para, a priori, prever todas as possibilidades de conflitos e, assim, tipificá-los de maneira exaustiva $^{119}$. A utilização da técnica da cláusula geral, dessa maneira, permite que a legislação não fique engessada no tempo de sua promulgação, possibilitando adequações conforme a evolução da sociedade e de seus postulados jurídicos.

Quando da atividade interpretativa a partir de uma cláusula geral, o julgador é sempre remetido a outro elemento apto a proporcionar a necessária concretização. E, para Judith Martins-Costa, esse reenvio se faz a elementos jurídicos ou extrajurídicos, ou seja, diante da vagueza do conceito, a cláusula-geral sempre promove um reenvio, que pode ser a outra norma jurídica, ou a elementos extrajudiciais, como padrões de comportamento e valores $^{120}$. E, nessa atividade, o julgador não se limita a estabelecer o

cooperação no direito processual civil português, p. 56). O autor se embasa nos ensinamentos de JUDITH MARTINS-COSTA, A boa-fé no direito privado, pp. 324-328.

${ }^{117} \mathrm{O}$ fato de a consequência jurídica ser também indeterminada é o que difere cláusula geral e conceito jurídico indeterminado: "Já por aí se percebe que, inobstante conter a cláusula geral, em regra, termos indeterminados, tais como os conceitos de que ora se trata (alguns destes conceitos indeterminados podendo indicar também princípios), a coincidência não é perfeita, pois a cláusula geral exige que o juiz concorra ativamente para a formação da norma. Enquanto nos conceitos indeterminados o juiz se limita a reportar ao fato concreto o elemento (vago) indicado na fattispecie (devendo, pois, individuar os confins da hipótese abstratamente posta, cujos efeitos já foram predeterminados legislativamente), na cláusula geral a operação intelectiva do juiz é mais complexa. Este deverá, além de averiguar a possibilidade de subsunção de uma série de casos-limite na fattispecie, averiguar a exata individuação das mutáveis regras sociais às quais o envia a metanorma jurídica. Deverá, por fim, determinar também quais são os efeitos incidentes ao caso concreto, ou, se estes já vieram indicados, qual a graduação que lhes será conferida no caso concreto, à vista das possíveis soluções existentes no sistema" (JUDITH MARTINS-COSTA, A boa-fé no direito privado, pp. 326327). No mesmo sentido, José MoACYR DoretTo NASCIMENTO, A boa-fé objetiva e o processo civil, p. 76; CÉSAR LEONARDO, Contraditório, lealdade processual e dever de cooperação subjetiva, p. 32.

118 JUDITH MARTINS-COSTA, A boa-fé no direito privado, pp. 298-299; ALDEMIRO REZENDE DANTAS JÚNIOR, Teoria dos atos próprios no princípio da boa fé, p. 98.

119 "Desde hace décadas, se ha venido comprobando que la vida tan acelerada y cambiante del siglo XX, y del actual, torna impensable uma previsión legislativa immutable, perfecta y completa" (MARCELO MESA e CARlos VIDE, La doctrina de los actos propios, p. 91). No mesmo sentido, Judith MARTINS-CostA, A boafé no direito privado, pp. 273-286; MENEZES CORDEIRO, Da boa fé no Direito Civil, p. 46; JORGE PEYRANO, La doctrina de los propios actos en el ámbito del procedimiento civil, p. 226; CARLOS J. COLOMBO, Inconducta procesal: temeridad o malicia, p. 829; LORENA BARREIROS, Fundamentos constitucionais do princípio da cooperação processual, p. 124. O tema da crise da positivação é, per si, alvo de estudos doutrinários bastante complexos, principalmente para que sejam compreendidas as formas de compensação da crise, dentre as quais, a técnica da cláusula geral.

120 Nas palavras da autora: “A sua concretização exige que o juiz seja reenviado a modelos de comportamento e a pautas de valoração que não estão descritos nem na própria cláusula geral nem, por vezes, no próprio ordenamento jurídico, podendo ainda o juiz ser direcionado pela cláusula geral a formar normas de decisão, vinculadas à concretização de um valor, de uma diretiva, de um padrão social, assim reconhecido como arquétipo exemplar da experiência social completa" (JUDITH MARTINS-CosTA, A boa-fé no direito privado, pp. 329-330). 
significado de uma norma, mas acaba por concretizá-la, preencher-lhe o conteúdo, de modo a contribuir para a própria criação do direito ${ }^{121}$.

O envio a critérios extrajurídicos, porém, não tem aceitação unânime na doutrina. Diz-se que tal permissividade significa abrir portas ao subjetivismo exacerbado do julgador, o qual poderia se valer de critérios diversos e que, sem qualquer base no direito, tornaria o julgamento imprevisível, corroborando para a insegurança jurídica ${ }^{122}$.

É por isso que se recomenda que, quando do preenchimento do conteúdo da cláusula geral, o julgador se valha de um procedimento racional que considere não só os usos e costumes médios da sociedade, mas também outros casos em que a mesma cláusula foi invocada, comparando os julgados de modo a buscar semelhanças e diferenças, e assim expor o raciocínio a partir do qual se cria o direito ${ }^{123}$.

Não se busca, com tais ponderações, excluir a técnica da cláusula geral, cuja imprescindibilidade é reconhecida pelos motivos já expostos, mas apenas objetivá-la de modo a serem dirimidos os riscos da insegurança jurídica decorrente do subjetivismo. Para isso, fundamental o papel da doutrina e da jurisprudência, os quais definirão os critérios objetivos a orientar o julgador ${ }^{124}$.

${ }^{121}$ JUDITH MARTINS-COSTA, A boa-fé no direito privado, p. 330. Segundo FRANZ WIEACKER, a aplicação do direito, de uma maneira geral, consiste em um método interpretativo que elege uma dentre as diversas valorações possíveis, de modo que "cada decisión constituye un elemento de una nueva creación de Derecho". Ocorre que "ello es tanto más así cuanto más indeterminada sea la prescripción del legislador" (El principio general de la buena fé, pp. 39-40), tal como as cláusulas gerais.

${ }^{122}$ Claudio Godoy, Função social do contrato, pp. 107-108. Especificamente com relação ao reenvio à equidade, DE LOS MOZOS afirma que "Si la equidad es necesaria para la realización de una justicia concreta y para el progreso del Derecho como consecuencia, no puede en cambio, ejercerse con unos criterios que se desarrollen al margen del Derecho, porque tan pernicioso es considerar a este reducido a la esfera de normas del ius strictum, como dejar fuera del ordenamiento, abierto a las presiones psicológicas, sociológicas o ideológicas, al ius aequum. Esto supone una falta de confianza en los valores jurídicos, uma desorientación típica de todo proceso de vulgarización que no puede tener otra disculpa que los conflictos espirituales y materiales entre Derecho y poder" (Metodologia y ciência en el derecho privado moderno, p. 323).

${ }^{123}$ Especificamente sobre esse procedimento racional de preenchimento do conteúdo da cláusula da boa-fé objetiva, CARLOS AlBERTO MotA PINTO afirma que o juiz “deverá ponderar-se o caso, segundo a vivência objetiva da boa fé, evidenciada pelos usos do tráfico e pelo fundo cultural médio da sociedade, compará-lo com os casos típicos já julgados, analisar o fundamento destas decisões e confrontá-lo com a situação, verificar se têm ou não a mesma legitimidade de aplicação ou se as circunstâncias do caso concreto, quando o sentido objetivo da boa fé nada nos esclareça, não aspiram, segundo um justo equilíbrio do interesse das partes, à existência desse dever; em todas estas operações ter-se-á presente que deve funcionar como elemento polarizador da apreciação, segundo a boa fé, o fim do contrato, enquanto gerador de uma confiança das partes" (Cessão de contrato, p. 254). Sobre as demais formas de concretização das cláusulas gerais, $c f$. FREDIE DIDIER JR., Cláusulas gerais processuais, pp. 273-277.

${ }^{124}$ Carlos Alberto Mota Pinto, Cessão de contrato, p. 254. A função da doutrina e da jurisprudência como norteadores da construção de elementos destinados ao preenchimento das cláusulas gerais é também ressaltado por FRANZ WIEACKER, El principio general de la buena fé, pp. 43-47. 
De qualquer modo, a discussão se faz menos presente para os interesses deste trabalho na medida em que a cláusula geral da boa-fé promove um reenvio ao princípio da boa-fé, que, por sua vez, é uma norma integrante do sistema jurídico ${ }^{125}$.

Assim é que, para Judith Martins-Costa, os conceitos de princípio e cláusula geral não se confundem, vez que: (i) como técnica legislativa, inexiste cláusula geral implícita, ao contrário dos princípios, (ii) dentre os princípios expressos, a cláusula se difere porque sempre promove reenvio, ao passo que os princípios não necessariamente o promovem, já que eles podem não ser dotados de vagueza - como exemplo, o princípio da irretroatividade da lei penal; (iii) dentre os princípios que também revelam valores e que também têm vagueza semântica, diferenciam-se das cláusulas gerais porque estas os contém, tal como a boa-fé ${ }^{126}$. Ou seja, a cláusula geral não traz em si qualquer valor, por ser uma simples técnica legislativa. Por meio de sua positivação no sistema é que alguns princípios se revelam, na hipótese em que o reenvio é feito justamente a um princípio.

Desse modo, após a edição do Código Civil de 2002, conclui-se pela existência, em nosso ordenamento, tanto do princípio da boa-fé, quanto da cláusula geral da boa-fé: é princípio, porque fundamenta uma série de normas jurídicas, porque é um valor a ser observado nos mais diversos ramos do direito, chegando-se a afirmar a qualidade da boa-fé como princípio geral do direito ${ }^{127}$. Traduz-se por meio de uma cláusula geral porque prevista como técnica legislativa de maneira expressa e genérica no

\footnotetext{
${ }^{125}$ São espécies de norma tanto os princípios quanto as regras, $c f$. VIRGÍlio AfONSO DA SILVA, Princípios e regras: mitos e equívocos acerca de uma distinção, p. 607. Felizmente, esquivamo-nos da discussão referente ao reenvio a elementos extrajurídicos, uma vez que ela é pertinente à própria filosofia e teoria geral do direito, como bem assevera TERESA NEGREIROS com relação aos princípios: “A configuração dos princípios como 'materialização de valores' nos coloca, de forma imediata, a questão de se saber de onde provêm tais valores, especificamente se intra ou extra sistemáticos. As respostas a este tipo de indagação comportam posturas diversas quanto à relação entre os sistemas jurídico e social, das quais, por sua vez, resultam posições ideológicas distintas no que respeita às funções da ordem jurídica" (Fundamentos para uma interpretação constitucional da boa-fé, p. 95).

${ }^{126}$ Judith MARTins-Costa, A boa-fé no direito privado, pp. 323-324. Teresa Negreiros, Fundamentos para uma interpretação constitucional do princípio da boa-fé, p. 87.

127 "A boa-fé é, portanto, ao lado de um standard jurídico, um princípio geral do Direito que se reveste de universalidade, estando presente - independentemente de sua recepção positiva (transformação em norma legal) - em todo o ordenamento jurídico, pois se constitui no eixo central da idéia mesma de Direito. Não se trata, portanto, de um princípio exclusivo do Direito Civil, em sentido estrito, embora apareça com maior nitidez neste setor em virtude de seu caráter de direito comum." (MARCo ANTONIO ZANELlato, Da boa-fé no direito privado, p. 88). No mesmo sentido: DÍEZ-PICAZO, La doctrina de los propios actos, p. 139; Flávio Alves Martins, A boa-fé objetiva, p. 13; MARCElo J. LóPEZ MESA, La doctrina de los actos propios: esencia y requisitos de aplicación, p. 192; JÔNATAS MILHOMENS, Da presunção da boa-fé no processo civil, p. 25.
} 
Código atual ${ }^{128}$, notadamente nos artigos 113, 187 e 422, cumprindo a função de mobilidade legislativa a que nos referimos.

\subsubsection{Boa-fé objetiva x boa-fé subjetiva}

Isso tudo que vimos diz respeito à boa-fé objetiva, que, por sua vez, não se confunde com a perspectiva subjetiva.

Em termos genéricos, a boa-fé subjetiva conceitua-se pelo estado de ignorância do sujeito, que acredita não infringir qualquer norma jurídica ao exercer determinada conduta. A essência da figura está no seu caráter subjetivo, pois diz respeito à intencionalidade do sujeito ao adotar um comportamento, na sua crença de que não exerceu qualquer atitude contrária ao ordenamento ${ }^{129}$. Contrapõe-se à má-fé, que é o agir em contrariedade à lei, e de maneira intencional ${ }^{130}$.

Mas, ainda com relação à boa-fé subjetiva, é comum a divisão entre duas diferentes modalidades, a psicológica e a ética: "a psicológica, que a caracteriza pela ignorância sobre a existência de impedimento, no ordenamento jurídico, em exercer determinada conduta; e a ética, que impõe que tal ignorância seja escusável, ou seja, em caso de negligência da parte, a boa-fé subjetiva estaria prejudicada"131.

Em outras palavras, a boa-fé psicológica é aquela que descrevemos, ou seja, que se caracteriza pela simples ignorância da afronta à determinada norma jurídica, pois o agente acredita estar em conformidade com a lei - sendo, assim, a que realmente se contrapõe com a má-fé: é preciso dolo ou culpa grave para descaracterizá-la, pois ainda que o agente tenha atuado com negliência ou imprudência, mantém-se inabalada sua boafé $^{132}$.

A boa-fé ética, por sua vez, configura-se quando o sujeito toma as devidas precauções e, ainda assim, crê na retidão de sua conduta; se, todavia, é negligente e não interpreta o contexto tal como um homem médio, deixando de perceber a ilicitude

\footnotetext{
${ }^{128}$ MARCELO DICKSTEIN, As funções da boa-fé objetiva e a proibição de comportamento contraditório, p. 85.

${ }^{129}$ Ruy Rosado de Aguiar Júnior, Proteção da boa-fé subjetiva, p. 190; Judith Martins-Costa, A boafé no direito privado, p. 412; ALEJANDRO BORDA, La teoria de los actos propios, p. 59; DíEZ-PICAZO, La doctrina de los propios actos, p. 135.

${ }^{130}$ ANTONIO DO PASSO CABRAL, O contraditório como dever e a boa-fé processual objetiva, p. 77.

${ }^{131}$ RUY ROSADO DE AGUIAR JÚNIOR, Proteção da boa-fé subjetiva, p. 193.

${ }^{132}$ FERNANDO NORONHA, O direito dos contratos e seus princípios fundamentais, p. 133.
} 
facilmente perceptível, a boa-fé deixa de existir, ainda que, em seu íntimo, ele acredite na licitude de seu comportamento. Vê-se, portanto, que a boa-fé ética é mais rígida, impondo ao agente um dever de cautela que, uma vez inobservado, afasta sua incidência ${ }^{133}$.

Tal rigidez advém de uma constatação realista: aferir a boa-fé de maneira apenas subjetiva é impossível para o Direito. O íntimo dos sujeitos não pode ser atingido, de modo que sempre o sistema recorre para os demais fatores da conduta do agente, aqueles que são externalizados e, portanto, perceptíveis ${ }^{134}$. Dessa maneira, a boa-fé puramente psicológica adquire pouca relevância prática, sendo a boa-fé ética aquela opção que melhor se coaduna com a função da decidibilidade do ordenamento: a partir da análise do contexto, bem como do comportamento do agente e seu esforço para não ser considerado negligente, conclui-se pela existência ou não da boa-fé subjetiva ${ }^{135}$.

Por esse mesmo motivo, a boa-fé objetiva vem ganhando cada vez mais relevância pela doutrina e pela jurisprudência. Trata-se de um padrão social de conduta, ligado à honestidade e à lealdade, de modo que o comportamento, para ser qualificado como de boa-fé em seu sentido objetivo, deve ser visto por terceiros como convergente com as regras de conduta coletivamente consideradas.

O intuito, aqui, é a proteção das expectativas geradas no convívio social, a partir de um comportamento que passa a ser objetivamente considerado, sem qualquer relevância dada ao íntimo do agente, à sua intenção de agir ou não conforme a licitude do sistema ${ }^{136}$. Assim, enquanto a boa-fé subjetiva é um fato, que serve de suporte fático para

\footnotetext{
133 "Nos quadros da concepção ética da boa-fé, exige-se, para que se possa falar em boa-fé subjetiva, uma ignorância que seja desculpável da situação de lesão de direito alheio. A ignorância seria indesculpável quando a pessoa houvesse desrespeitado deveres de cuidado; ela estaria de má-fé mesmo quando pudesse atribuir-lhe um desconhecimento meramente culposo." (FERNANDO NORONHA, O direito dos contratos e seus princípios fundamentais, p. 134).

${ }^{134}$ JôNATAS MilhOMENS, Da presunção de boa-fé no processo civil, p. 9.

${ }^{135}$ As advertências quanto à inviabilidade prática da boa-fé psicológica são de MENEZES CORDEIRO: "Mas sendo assim - e é assim - a concepção psicológica da boa fé torna-se, aquando da aplicação, numa aparência. $\mathrm{O}$ esquema real é outro: reunidos os indícios, o juiz constata que a pessoa em causa deve encontrar-se nas referidas situações de ciência ou de ignorância porque, das duas uma: ou se encontra, de facto, nelas ou, não se encontrando, devia encontrar-se, dados os factores que a rodeiam. Ou sabe, ou deve saber, sendo certo que apenas o último termo é susceptível de apreciação e de controlo. Querer, com base absoluta, aplicar uma concepção psicológica da boa fé é um logro, a nível de decisão: como em qualquer esquema de aplicação do Direito, arredado o espectro da subsunção, é sempre necessário emitir um juízo, a cargo do intérpreteaplicador. E este, guiando-se pelas situações típicas tidas por normais, efectua uma valoração sujeito-indícios e não uma declaração de ciência sobre a mente humana. Esta escapa ao Direito, sendo desejável que assim continue. Tal valoração implica, na prática, o recurso encapotado à boa fé ética." (Da boa fé no Direito Civil, pp. 515-516).

${ }_{136}$ DíEz-PICAZO, La doctrina de los propios actos, p. 135; ANTONIO DO PASSO CABRAL, O contraditório como dever e a boa-fé processual objetiva, p. 78; MARCELO DICKSTEIN, As funções da boa-fé objetiva e a proibição de comportamento contraditório, p. 86; RUY ROSADO DE AGUIAR JÚNIOR, Proteção da boa-fé subjetiva, p. 191; JUDITH MARTINS-COSTA, A boa-fé no direito privado, p. 412.
} 
diversas normas, a boa-fé objetiva é princípio, uma norma de conduta a regular o comportamento dos sujeitos de determinada relação ${ }^{137}$.

Esse é o limite do que se pode dizer em termos conceituais sobre a boa-fé objetiva, pois uma definição estanque não é tarefa simples: a carga valorativa que a envolve impede que a boa-fé objetiva seja delimitada a priori. Seu conteúdo material, portanto, depende de circunstâncias específicas, conforme cada caso a ser analisado pelo Judiciário. Não obstante, é um conceito sempre relacionado à probidade, lealdade e honestidade $^{138}$.

Tanto a boa-fé objetiva quanto a subjetiva possuem um elemento valorativo em comum, pois são figuras destinadas a preservar a lealdade e a honestidade no tráfego jurídico, além de ambas tutelarem a confiança ${ }^{139}$. Diferem-se, por sua vez, no que se refere à perspectiva a partir da qual são analisadas: pela boa-fé subjetiva, busca-se a lealdade do sujeito com o ordenamento jurídico, ao passo que, pela boa-fé objetiva, a lealdade protegida é aquela estabelecida perante terceiros ${ }^{140}$. Assim, na primeira, a confiança é subjetiva, existente entre a aparência da situação na qual o sujeito se insere e o seu íntimo de confiar na retidão de seu comportamento. Na segunda, a confiança se manifesta perante a sociedade ${ }^{141}$.

A partir da conceituação e diferenciação entre elas, torna-se evidente que a boa-fé constantemente relacionada ao venire é aquela objetivamente considerada, já que o escopo da vedação a comportamentos contraditórios é justamente a proteção das expectativas geradas a outrem quando da adoção de um primeiro comportamento.

\footnotetext{
137 Sobre a distinção entre boa-fé subjetiva e objetiva como fato e norma, respectivamente, $c f$. FRANZ WIEACKER, El principio general de la buena fe, p. 12; FERNANDO NORONHA, O direito dos contratos e seus princípios fundamentais, p. 132; FREDIE DIDIER JR., Fundamentos do Princípio da Cooperação no Direito Processual Civil Português, p. 81; Osvaldo GoZAínI, La conducta en el proceso, pp. 16-18.

138 “Com efeito, a realização do Direito através da decisão do caso concreto é constitutiva de seu conteúdo. A boa-fé, em sua acepção objetiva, carece de uma concretização metalegislativa, afigurando-se, por isso, como uma privilegiada base empírica para uma reflexão justeórica que parta da premissa segundo a qual a decisão - é parte constitutiva do Direito, no sentido de que o Direito é construído, e não pré-dado" (TERESA NEGREIROS, Fundamentos para uma interpretação constitucional do princípio da boa-fé, p. 19). No mesmo sentido, cf. Flávio Alves MaRTins, A boa-fé objetiva e sua formalização no Direito das Obrigações Brasileiro, p. 9; MARCO ANTONIO ZANELlato, Da boa-fé no direito privado, pp. 63-65; LEIDE SANTOS, Boa-fé objetiva no processo civil, p. 23.

${ }^{139}$ CAMILA GonÇAlves, Princípio da boa-fé, p. 41.

${ }^{140}$ RuY Rosado DE AGUIAR JÚNIOR, Proteção da boa-fé subjetiva, pp. 191-192.

${ }^{141}$ FERNANDO NORONHA, $O$ direito dos contratos e seus princípios fundamentais, p. 136.
} 


\subsubsection{Funções da boa-fé objetiva}

Antes de pormenorizar a relação entre boa-fé objetiva e venire, analisemos de maneira sucinta as funções que a boa-fé objetiva assume no ordenamento civilista. São elas as funções interpretativa, supletiva e corretiva ${ }^{142}$.

A função interpretativa está estampada no artigo 113 do Código Civil. Ao afirmar que "os negócios jurídicos devem ser interpretados conforme a boa-fé e os usos do lugar de sua celebração" estabelece-se a boa-fé como critério interpretativo a ser observado na relação obrigacional. Assim, o verdadeiro sentido de determinada estipulação negocial, em caso de dúvida ou obscuridades, deve ser alcançado buscando-se a interpretação que privilegie o sentido conforme a lealdade e honestidade ${ }^{143}$. Nota-se, por meio do exercício dessa função, a integração do conteúdo das vontades das partes, que mais do que consideradas como sobrepostas uma a outra, devem ser tidas como fundidas, analisando-se a todo o momento o interesse de ambas as partes ${ }^{144}$.

A função supletiva ou integrativa, por sua vez, é a segunda função, a qual veio positivada pelo artigo 422 do Código Civil: “Os contratantes são obrigados a guardar, assim na conclusão do contrato, como em sua execução, os princípios de probidade e boafé.”. Por meio dessa função, portanto, são criados deveres anexos à obrigação principal (também chamados de deveres laterais), o que significa dizer que, ainda que não tenham sido expressamente estabelecidos pelas partes - ou seja, ainda que inexista manifestação de vontade das partes nesse sentido -, eles são exigíveis porque decorrentes da cominação legal de que elas devem agir conforme a boa-fé ${ }^{145}$. É comum se identificar como deveres anexos os de informação, sigilo, segurança, entre outros, conforme as peculiaridades do caso concreto. Em verdade, a enumeração a priori de todos os possíveis deveres acessórios não é viável justamente porque dependerão do contexto negocial de cada caso concreto ${ }^{146}$.

\footnotetext{
142 Antonio JunqueIRA DE AzEVedo, Novos estudos e pareceres de Direito Privado, p. 25; ANDERSON SCHREIBER, A proibição de comportamento contraditório, pp. 86-90; CLAUDIO GodOY, Função social do contrato, p. 76; FERNANDO NORONHA, O direito dos contratos e seus princípios fundamentais, p. 151; HUMBERTO THEODORO JÚNIOR, Boa-fé e processo: princípios éticos na repressão à litigância de má-fé, p. 638; Judith MARTins-Costa, A boa-fé no direito privado, pp. 427-428; MARCELO DicksteIn, As funções da boa-fé objetiva e a proibição de comportamento contraditório, p.87; ALDEMIRO REZENDE DANTAS JÚNIOR, Teoria dos atos próprios no princípio da boa fé, p. 223.

${ }_{143}$ ANDERSON SCHREIBER, A proibição de comportamento contraditório, p. 86.

${ }^{144}$ Clóvis Couto E Silva, A obrigação como processo, pp. 35-36.

145 MARCELO DiCKSTEIN, As funções da boa-fé objetiva e a proibição de comportamento contraditório, p. 85.

${ }^{146}$ ANDERSON SCHREIBER, A proibição de comportamento contraditório, p. 87; DÍEZ-PICAZO, La doctrina de los propios actos, p. 141.
} 
E, por fim, o artigo 187 do Código Civil evidencia a função corretiva, impeditiva ou limitativa do exercício de direitos. Ao afirmar que "também comete ato ilícito o titular de um direito que, ao exercê-lo, excede manifestamente os limites impostos pelo seu fim econômico ou social, pela boa-fé ou pelos bons costumes.”, o referido artigo impõe limites ao exercício de atos que inicialmente seriam lícitos, mas se tornam ilícitos diante da afronta à boa-fé, ou aos outros dois critérios elencados. Trata-se do abuso do direito, figura a ser estudada no item seguinte.

\subsubsection{Boa-fé objetiva e venire}

O venire é relacionado à boa-fé objetiva na sua função corretiva, ou seja, para concretizar a função impeditiva de exercício de direitos desempenhada pela boa-fé ${ }^{147}$ : o comportamento contraditório, de modo a contrariar o standard da boa-fé em seu sentido objetivo, enseja a proteção da confiança de modo que o exercicio do segundo comportamento, apesar de lícito, é impedido pela incidência do venire.

Nesse ponto, pertinente a menção à distinção feita pela doutrina entre venire e tu quoque, por serem ambas as figuras destinadas a impedir o exercício de direitos em inobservância da boa-fé e pela prática de comportamentos contraditórios.

Pela figura do tu quoque, entende-se traduzida para o direito a regra de ouro segundo a qual não se deve fazer para o outro aquilo que não se quer que seja feito a si mesmo $^{148}$. Visando ao respeito à igualdade de tratamento entre as partes, aquele que infringiu uma norma não pode reclamar a infração de outrem, pois estaria utilizando de maneira contraditória os mesmos critérios jurídicos, apenas para se beneficiar ${ }^{149}$.

Assim, o tu quoque é comumente posicionado ao lado do venire, para que, juntos, sejam classificados como espécies de um mesmo gênero, o da vedação à contradição $^{150}$. Difeririam-se, porém, porque no tu quoque a contradição não está no

\footnotetext{
${ }^{147}$ Claudio Godoy, Função social do contrato, p. 88; Aldemiro ReZEnde Dantas Júnior, Teoria dos atos próprios no princípio da boa fé, p. 298.

${ }^{148}$ FRANZ WIEACKER, El principio general de la buena fé, p. 67.

${ }^{149}$ Na definição de MENEZES CORDEIRO: "A fórmula tu quoque traduz, com generalidade, o aflorar de uma regra pela qual a pessoa que viole uma norma jurídica não poderia, sem abuso, exercer a situação jurídica que essa mesma norma lhe tivesse atribuído" (Da boa fé no Direito Civil, p. 837).

${ }^{150}$ Claudio GodoY, Função social do contrato, pp. 87-88.
} 
comportamento do agente propriamente dito, "mas nas bitolas valorativas por ele utilizadas para julgar e julgar-se"

Para ANDERSON SCHREIBER, mesmo com essa especificidade relacionada às bitolas valorativas, "há no núcleo do tu quoque uma idéia de contradição, uma incoerência" ${ }^{152}$, o que permitiria enquadrá-lo como subespécie do venire. Mas MENEZES CORDEIRO aponta uma diferenciação que não pode deixar de ser acolhida: enquanto o venire contra factum proprium protege a confiança do terceiro que acreditou nas expectativas emanadas do factum proprium, no inadimplemento mútuo do contrato há uma situação de infidelidade de ambas as partes, de modo que o tu quoque acaba por garantir que o infiel não se passe por sujeito de boa-fé, aqui na sua acepção subjetiva.

Assim, concluiu o autor que, para tentar inserir o tu quoque como uma modalide de venire, ter-se-ia que defender uma ideia estranha à própria finalidade deste instituto: "a pessoa cuja contraparte contratual prevarique, tinha razões para acreditar que não mais lhe seria exigida a sua prestação, baseando, nessa locubração, uma actividade posterior, em termos de investimento de confiança"153. Logo, diante da inexistência de confiança do segundo prevaricador a ser tutelada, as figuras não podem ser igualadas, excluindo-se do objeto do presente estudo a figura do tи quoque.

Concluído o quanto exposto no que se refere à relação entre venire e boa-fé objetiva, convém ressaltar que esta, como parâmetro de conduta a ser observado nas relações obrigacionais, funciona como uma das bases jurídicas em nosso ordenamento para a incidência do venire. Isso porque, pela incidência da boa-fé como princípio geral do direito, identifica-se um dever de coerência ao se comportar perante a sociedade sempre que, por meio do exercício de uma conduta, tenham sido geradas expectativas em terceiros. A ruptura dessa coerência, portanto, significa romper a boa-fé, o que evidencia a relação entre esta e o venire ${ }^{154}$ : este se destina a proteger aquela.

Entretanto, muito pertinente a advertência de MENEzes DE CORDEIRO, com relação à frequente referência doutrinária e jurisprudencial entre boa-fé objetiva e venire, ao afirmar que "no fundo, a boa fé funciona, aí, como apoio linguístico para soluções encontradas com base noutros raciocínios (...) ou como um esquema privilegiado de

\footnotetext{
${ }^{151}$ Menezes CordeIro, Da boa fé no Direito Civil, p. 843.

152 ANDERSON SCHREIBER, A proibição de comportamento contraditório, p. 184.

${ }^{153}$ Menezes CordeIRo, Da boa fé no Direito Civil, p. 843.

${ }^{154}$ DíEZ-PICAZO, La doctrina de los propios actos, p. 143.
} 
conseguir amparo numa disposição legal - a que consagra a boa fé - para a solução definida" ${ }^{\prime 155}$.

Em outras palavras, sustenta o autor que a simples menção à boa-fé é algo impreciso e sem conteúdo bem definido, servindo apenas de apoio legislativo para justificar a incidência do venire, mas sem permitir a real compreensão do fenômeno. A relação entre boa-fé e venire é apenas útil na medida em que aquela se relaciona com a confiança, pressuposto indispensável para a vedação a comportamentos contraditórios, vez que é a própria justificativa para sua incidência.

A confiança é, portanto, o critério de decisão que faltava para que a boa-fé deixasse de ser uma figura amorfa, preenchendo-lhe o conteúdo de maneira concreta, afastando-se da abstração inerente ao puro conceito de boa-fé objetiva. Diz-se critério de decisão porque permite a seguinte constatação: "um comportamento não pode ser contraditado quando ele seja de molde a suscitar a confiança das pessoas ${ }^{156 "}$.

Usa-se a referência à boa-fé, portanto, como elemento legislativo de concretização da confiança, que, por sua vez, é o apoio e a justificativa axiológica para a incidência do venire.

\subsubsection{Abuso do direito}

Pelo abuso do direito, tem-se um mecanismo de limitação ao exercício de situações jurídicas subjetivas, sempre que esse exercício se revelar danoso a terceiros, ainda que potencialmente. A figura surge da necessidade de se limitar a concepção individualista oitocentista com relação ao conceito de direito subjetivo, acompanhando, assim, a alteração dos valores da sociedade, que passa a se preocupar com a solidariedade e o harmônico convívio social ${ }^{157}$, à semelhança do contexto já ressaltado em que o estudo do venire conseguiu ganhar força (item 3.1. supra).

\footnotetext{
${ }^{155}$ Menezes Cordeiro, Da boa fé no Direito Civil, p. 753.

${ }^{156}$ MeneZes CordeIRo, Da boa fé no Direito Civil, p. 753.

${ }^{157}$ CARlos SESSAREgo afirma que o abuso do direito surgiu da crise da ciência jurídica, caracterizada pela percepção de que os direitos subjetivos não poderiam ser considerados como absolutos, ideia que "tenía que dejar paso a una concepción donde el valor solidariedad debería ser vivenciado a nivel de las relaciones sociales" (Abuso del derecho, p. 16).
} 
Se o abuso do direito teve sua autonomia e importância reconhecidas vagarosa e paulatinamente, hoje a relevância do instituto é inconteste, fazendo-se presente de maneira positivada em inúmeros ordenamentos jurídicos ${ }^{158}$, inclusive no brasileiro, por meio do atual artigo 187 do Código Civil.

No início, muito se discutiu sobre a autonomia da figura, sobre a necessidade de ser por ela desempenhada uma função que já estava bem resguardada pelo ato ilícito e pela responsabilidade civil. O dogma da dicotomia entre ato lícito e ilícito fazia parecer com que não houvesse espaço para uma figura intermediária ${ }^{159}$, que partisse da existência de um direito (portanto, da licitudade), cujo exercício anormal não seria admitido pelo ordenamento (tornando-se, assim, ilícita).

Entretanto, principalmente a fim de refutar a alegação de ausência de autonomia do abuso do direito, firmou-se a diferença entre ato abusivo e ato ilícito em seu sentido tradicional, porquanto diferentes os requisitos configuradores de cada instituto. Tal diferenciação não está na existência ou não do elemento subjetivo, já que ambas as figuras prescindem da averiguação da volitividade: o ato ilícito é aquele que viola uma norma proibitiva do ordenamento ${ }^{160}$, a despeito da análise da culpabilidade do ato, elemento que se faz relevante apenas para a configuração de eventual responsabilidade civil subjetiva ${ }^{161}$.

Da mesma maneira, ainda que tenha havido a defesa do abuso do direito como instituto cuja configuração requer imprescindivelmente o elemento subjetivo - seja o dolo ou a culpa grave, seja a negligência de não medir as consequências do exercício daquele

\footnotetext{
${ }^{158}$ Para um referência completa de cada ordenamento que prevê o abuso do direito, $c f$. CARLOS SESSAREGO, Abuso del derecho, pp. 189-320.

${ }^{159}$ PlANIOL é o expoente máximo da crítica ao conceito de abuso de direito por não ser possível vislumbrar uma figura intermediária entre o lícito e o ilícito. Nas suas palavras: "o direito cessa onde o abuso começa, e não pode haver uso abusivo de qualquer direito pela razão irrefutável de que um só e mesmo acto não pode ser simultaneamente conforme ao direito e contrário ao direito" (apud FERNANDO CUNHA DE SÁ, Abuso do direito, pp. 322-323).

${ }^{160}$ Fernando Cunha de SÁ, Abuso do direito, p. 502; CARlos SeSsarego, Abuso del derecho, pp. 135-136. 161 "Em última análise, parece, assim, preferível continuar a entender a culpabilidade no sentido tradicional de juízo sobre o agente de certo comportamento e tê-la como possível pressuposto da responsabilidade civil não já, porém, como elemento ou requisito da ilicitudade, que, essa, pela sua oposição lógica ao valor ínsito numa específica proibição normativa, respeita ao próprio acto, objectivamente e com independência de qualquer conteúdo volitivo ou de inteligência da parte de quem o realizou” (FERNANDO CUNHA DE SÁ, Abuso do direito, p. 511). Entretanto, há quem entenda que o ato ilícito depende da culpabilidade para sua caracterização, $c f ., v . g$., FERNANDO NORONHA, $O$ direito dos contratos e seus princípios fundamentais, $\mathrm{p}$. 175. Para quem defende essa ideia, a diferenciação entre abuso e ilícito é ainda mais evidente, já que aquele seria antijurídico, ao passo que este depende também do elemento subjetivo.
} 
direito perante terceiros, seja a ausência de legítimo interesse nesse exercício ${ }^{162}$ predominou a corrente objetiva.

Isso porque a concepção puramente subjetiva se mostrou insuficiente, por acabar limitando a utilização do abuso, que dependeria da demonstração do íntimo do sujeito para sua configuração, o que é sempre bastante improvável de ser revelado. Ademais, essa concepção acaba deixando de fora situações de abuso do direito em que não houve intenção de prejudicar e, mesmo assim, foram observados danos a outrem ${ }^{163}$. Daí a maior aceitação do elemento puramente objetivo como suficiente para a configuração do abuso do direito, o que significa dizer que ele passa a prescindir de elemento subjetivo para sua configuração ${ }^{164}$.

Assim, a diferenciação entre ilícito em seu sentido tradicional e ato abusivo está em outro elemento que não a subjetividade. Para CARLOS SESSAREGO, o abuso corresponde a um ato ilícito sui generis, que difere do ato ilícito geral porque se origina sempre de um ato lícito, o que traz a necessidade, pelo juiz, de valorar se o exercício do direito, inicialmente lícito, torna-se ilícito por afrontar os valores do sistema ${ }^{165}$. O ato ilícito, por sua vez, ao corresponder a uma afronta direta à lei, prescinde da análise valorativa $^{166}$.

Todavia, justamente com base no fato de o ato abusivo ferir valores do ordenamento, defende-se que ele pode ser considerado como um ato ilícito em sentido amplo, ou seja, como ato que fere normas ou valores do sistema ${ }^{167}$. Para nós, irrelevante a discussão classificatória do abuso como ilícito ou não, pelo desvio que a controvérsia

\footnotetext{
162 Sobre as subdivisões da corrente subjetivista do abuso do direito, $c f$. CARLOS SESSAREGO, Abuso del derecho, pp. 125-127.

163 "Las dificultades en la prueba,que dejaría sin protección a muchos perjudicados, y la limitación del abuso a sólo los casos específicos de intencionalidad de la acción emprendida o la de ausência de un interés serio y legítimo de parte del actor, hacen que esta concepción sea vulnerable e insuficiente para describir los alcances del abuso del derecho" (CARLOS SESSAREGO, Abuso del derecho, p. 128)

${ }^{164}$ A prescindibilidade do elemento subjetivo apenas traduz a possibilidade de ser configurado o abuso sem a intenção de prejudicar, a averiguação da culpa em seus diversos graus ou do interesse no exercício de um direito. Todavia, presente essa intenção, corrobora-se a existência do abuso, sendo oportuno afirmar, portanto, que a teoria objetiva ou finalista é mais ampla do que a subjetiva, abarcando também os casos que esta qualifica como abuso de direito. Nesse sentido afirma FERNANDO NORONHA, $O$ direito dos contratos e seus princípios fundamentais, p. 172.

165 Abuso del derecho, pp. 159-161.

166 Tal visão é corroborada pelos pensamentos de FERNANDO CUNHA DE SÁ, para quem "enquanto a ilicitudade é, desde logo, directa e frontal violação dos limites formais do direito ou da prerrogativa em causa, já o acto abusivo finge a aparência estrutural desse mesmo direito ou prerrogativa, assim encobrindo a violação da sua intenção normativa" (Abuso do direito, p. 634).

167 Nesse sentido, $c f$. MARIA CAROlina SilveIRA BERALDO, Comportamento dos sujeitos processuais, pp. 100-101; ANDRÉ LUIS CARRADITA, Abuso de situações jurídicas processuais no Código de Processo Civil, p. 176.
} 
representa com relação ao nosso objeto de estudo, bem como pelo fato de o Código Civil de 2002 ter suavizado qualquer controvérisa, ao considerar expressamente o ato abusivo como uma espécie de ato ilícito.

Tanto o ato ilícito em sentido estrito quanto o ato abusivo podem culminar na responsabilidade civil, desde que os elementos desta restem configurados. Para que seja possível se falar em responsabilidade, fundamental a identificação do dano, bem como do nexo causal entre aquele e o ato ilícito ou abusivo. Desta feita, o dano não é elemento para configuração do ato abusivo ou do ato ilícito, mas apenas da responsabilidade civil, seja ela fundada no abuso do direito ${ }^{168}$, seja no ato ilícito em sentido estrito.

Entretanto, considerando o já exposto com relação à prescindibilidade do elemento subjetivo para a configuração do abuso do direito, a constatação do abuso somente pode acarretar espécie de responsabilidade objetiva. Assim sendo, o artigo 187 do Código Civil é o responsável por introduzir no ordenamento brasileiro uma nova espécie de responsabilidade civil objetiva, a qual surge de um comportamento inicialmente lícito e da qual culpa não é elemento caracterizador ${ }^{169}$. Daí sua importância e autonomia.

São requisitos para a configuração do abuso do direito (i) o exercício de um direito subjetivo; (ii) a titularização desse direito pelo agente; (iii) que, por meio desse exercício, firam-se os limites impostos pelo fim econômico e social do direito, pela boa-fé ou pelos bons costumes; e (iv) que a afronta a esses valores seja manifesta ${ }^{170}$.

Assim, além da aparência do direito, fundamental o desvio da finalidade do exercício com relação aos próprios fins a que ele se destina. Para FERnANDo CunHA DE SÁ, "a aparência estrutural do direito não é integrada pela sua intenção normativa; a forma está presente, mas o seu preciso valor está ausente, a realidade finge o direito", fazendo-se necessário apreender o sentido axiológico-jurídico do direito para averiguar se seu exercício feriu esse sentido.

Há quem critique a autonomia do abuso do direito porquanto suficiente a existência da boa-fé objetiva para limitar o exercício de situações jurídicas ${ }^{171}$. Ocorre que,

\footnotetext{
${ }^{168}$ FERNANDO CUNHA DE SÁ, Abuso do direito, p. 632.

169 JUDith MARTINS-COSTA, A ilicitude derivada do exercício contraditório de um direito, pp. 122-124; Carlos Sessarego, Abuso del derecho, p. 180; PAUlo Mota PINTO, Sobre a proibição do comportamento contraditório no Direito Civil, p. 177.

${ }^{170}$ Helena ABDo, O abuso do processo, p. 46.

${ }^{171}$ Ao relatar a experiência alemã de previsão da chicana (figura que entendia inadmissível o exercício de um direito quando a finalidade fosse prejudiciar alguém), MENEZES CORDEIRO descreve: "Nas insuficiências do $\S 826$, houve que buscar uma disposição portadora de um princípio geral de Direito, suficientemente vasto
} 
apesar da íntima relação entre boa-fé e abuso, aquela é insuficiente para explicar com exatidão o fenômeno do abuso, que depende dos pressupostos supra elencados, servindo a boa-fé como valor destinado a caracterizar um dos pressupostos, qual seja, o desvio de finalidade, a imposição de um limite ao direito.

Desse modo, a boa-fé é fundamento axiológico-normativo ${ }^{172}$ presente em todo o ordenamento jurídico e responsável por servir de parâmetro para considerar o exercício de determinado direito subjetivo como inadmissível ${ }^{173}$. "O abuso do direito ganha, sob essa concepção, a tarefa de conformar a autonomia privada aos valores que o ordenamento jurídico pretende, por meio daquela situação subjetiva específica, tutelar"174. E, certamente, dentre esses valores, destaca-se a boa-fé ${ }^{175}$.

Ao tratarmos da boa-fé e de suas três funções, estabelecemos que aquela limitadora do exercício de posições jurídicas está presente no artigo 187 do Código Civil. Disso se conclui que a relação entre boa-fé e abuso de direito não é de subordinação; mais correto considerá-las como figuras coexistentes e de funcionalidade independente, apesar de se encontrarem ao reprimir o exercício de determinados direitos subjetivos, quando contrários aos valores tutelados pelo ordenamento.

Bastante ilustrativa a relação entre a boa-fé e o abuso de direito delineada por ANDERSON SCHREIBER. O autor constrói a figura de dois círculos secantes, um para a boafé e outro para o abuso do direito. Na parte do círculo da boa-fé que não se comunica com

para controlar o exercício de quaisquer direitos privados, positivo no sentido de prescrever condutas e não, apenas, na sua falta, indemnizações, e objectivo, por ignorar elementos atinentes ao agente, como o dolo e a negligência. A disposição em causa, que deveria, também, estar em plena expansão científica, foi encontrada no $§ 242$ BGB: 'O devedor está obrigado a executar a prestação tal como o exige a boa-fé, com consideração dos costumes do tráfego"”. (Da boa-fé no Direito Civil, p. 694). Assim, para o autor, a boa-fé cumpre de modo mais eficiente a função do abuso do direito. Para um estudo aprofundado do tema, $c f$. pp. 661-718 da mesma obra.

${ }_{172}^{172}$ A expressão é de ANDERSON SCHREIBER, A proibição de comportamento contraditório, p. 114.

173 Por esse motivo, para CARlos SESSAREGO, a configuração do abuso do direito independe de norma expressa em cada ordenamento. Sua ilicitude é constatada, a despeito de norma expressa, pelo exercício do direito violar princípios gerais, dentre os quais, o da boa-fé. Nas palavras do autor: "El acto abusivo es ilícito por transgredir la concreta norma jurídica que aloja el principio general que no ampara el abuso de derecho, como ocurre em determinados ordenamientos contemporâneos y, en ausencia de diche específica norma, es ilícito por violar algún otro principio general del derecho, como es el caso de la buena fe o de las buenas costumbres, principios de raíz moral de los que se nutre la conciencia jurídica colectiva" (Abuso del derecho, p. 152).

174 ANDERSON SCHREIBER, A proibição de comportamento contraditório, p. 115.

175 Para FernANDo NoRONHA, o problema prático de se saber quando um direito é exercido de maneira contrária à sua função, a fïm de viabilizar a configuração do abuso do direito, só se resolve com base na boafé: "Realmente importante é saber que o verdadeiro critério do abuso de direito parece estar no princípio da boa-fé: o que importa assinalar é, primeiro, que a boa-fé exige de cada parte que, ao exercer os seus direitos, haja com moderação e, segundo, que se a discricionariedade concedida aos particulares constitui a sua esfera de autonomia privada, a boa-fé, agora, terá uma função de limite a tal autonomia" ( $O$ direito dos contratos $e$ seus princípios fundamentais, p. 173). 
o do abuso do direito estão as suas outras funções, a interpretativa e a criadora de deveres anexos; já no círculo do abuso do direito, a parte isolada é preenchida pelos bons costumes e fins econômicos-sociais, outros valores do nosso ordenamento que permitem que o exercício de um direito seja limitado. O campo em que ambos os círculos se comunicam, por sua vez, diz respeito à limitação do exercício de um direito pela boa-fé.

Com base nisso, é de fato um falso problema aquele existente na doutrina com relação a qual das duas categorias - boa-fé ou abuso do direito - seria enquadrável o venire. Pelo contrário, diante da parcial coincidência de conteúdos, o venire contra factum proprium situa-se na seguinte categoria: um abuso do direito por violação à boa-fé ${ }^{176}$.

Por isso, firmada a coexistência entre ambos os fundamentos jurídicos capazes de embasar a aplicação do venire, não há contradição entre os autores que apontam apenas um dos fundamentos. Mais correto dizer que lhes falta completude, e que o venire concretiza hipótese de conexão entre a boa-fé e o abuso de direito ${ }^{177}$.

\subsubsection{Solidariedade social}

Os fundamentos jurídicos para o venire não se esgotam no princípio da boa-fé e do abuso do direito. Há também um princípio previsto no artigo $3^{\circ}$ da Constituição que o justifica e o impulsiona: o princípio da solidariedade social.

\footnotetext{
176 “O comportamento contraditório é abusivo, no sentido de que é um comportamento que, embora aparentemente lícito, se torna ilícito, ou inadmissível. E isto justamente porque seu exercício, examinado em conjunto com um comportamento anterior, afigura-se contrário à confiança despertada em outrem, o que revela, no âmbito normativo, contrariedade à boa-fé objetiva" (A proibição de comportamento contraditório, pp. 119-121). No mesmo sentido: "Una adecuada colocación sistemática de la doctrina de los actos propios, dentro del esquema general del Derecho civil, sólo puede hacerse situándola dentro de la teoría general de los límites del derecho subjetivo y más concretamente dentro de los límites impuestos po la buena fe" (DíEZPICAZO, La doctrina de los propios actos, p. 186). Não obstante, DíEZ-PICAZO somente reconhece íntimas conexões entre o abuso e o venire, sem considerar este como uma espécie daquele, o que se atribui, talvez, à falta de desenvolvimento da figura do abuso à época em que o autor desenvolveu sua obra. Ainda no sentido que ora defendemos, $c f$ : MARCo ANTONIO ZANEllato, Da boa-fé no direito privado, p. 137, JORGE PEYRANO, La doctrina de los propios actos en el ámbito del procedimiento civil, pp. 227-228.

${ }^{177}$ Ressalta-se que não é esta a única visão presente na doutrina. Há quem disserte sobre a possibilidade de tanto o abuso quanto a boa-fé servirem de base para aplicação do venire, para concluir pela aplicação de apenas um dos institutos: "E é nesta ordem de ideias, partindo do postulado de que há que clarificar a distinção, que nos parece que a boa-fé constitui um padrão mais próximo e talvez mais adequado para proibir o venire contra factum proprium que a simples e genérica invocação do abuso de direito - instituto com vocação específica para traduzir, como dissemos, um último e irrecusável nível de funcionalização dos direitos à realização dos interesses capazes de justificar o seu reconhecimento ao titular." (PAULO MOTA PINTO, Sobre a proibição do comportamento contraditório no direito civil, p. 182).
} 
A vida em sociedade impõe que haja preocupação e respeito com o próximo, o que, uma vez admitido pelo Direito, passou a servir de base para a limitação do exercício de direitos subjetivos e da autonomia privada. Essa noção veio consubstanciada em nosso ordenamento pelo princípio da solidariedade social.

A relação desse princípio com o venire contra factum proprium reside no fato de este tutelar a confiança, as expectativas geradas nas relações sociais, o que não deixa de ser uma manifestação da preocupação com o próximo ${ }^{178}$. O venire é importante instrumento de efetivação da solidariedade e da coesão social, impondo um padrão de conduta, um arquétipo social cujo reconhecimento permite a construção de certa previsibilidade no modo de agir das pessoas, que passam a poder esperar condutas coerentes entre $\mathrm{si}^{179}$.

Como o venire tem base na boa-fé, esta também tem relação com a solidariedade social. É por meio deste princípio que a boa-fé objetiva atinge bases constitucionais $^{180}$. Afinal, a aplicação da boa-fé pressupõe critérios sociais do que se entende por conduta leal e, em nossa sociedade, há lealdade quando adotados comportamentos cooperativos, convergentes com a visão solidária e respeitosa da dignidade do ser humano ${ }^{181}$.

Assim, tutelar a confiança por meio da aplicação do venire significa garantir a presença da boa-fé objetiva, na função que se comunica com o abuso do direito; significa a limitação do exercício de direitos subjetivos quando eles afrontarem a confiança legitimamente gerada; significa também garantir que os sujeitos cogitem as implicações que seus comportamentos geram nos outros.

Os temas estão todos interligados. Boa-fé, abuso de direito e solidariedade social são conceitos conexos, pois, dentre as funções que assumem, tutelam a confiança

\footnotetext{
${ }^{178}$ ANDERSON SCHREIBER, A proibição de comportamento contraditório, p. 107.

${ }^{179}$ PUIG BRUTAU, Estudios de derecho comparado, p. 115.

180 ALDEMIRO REZENDE DANTAS JÚNIOR, Teoria dos atos próprios no princípio da boa-fé, pp. $126-127$.

181 "As bases constitucionais do princípio da boa-fé encontram-se na dignidade da pessoa humana e na solidariedade, pois o tratamento probo, veraz e leal, que se traduz como digno de confiança, é colorário dos direitos da personalidade, sendo que o respectivo descumprimento e a desconsideração do outro ferem a dimensão moral dos direitos da personalidade e, portanto, a dignidade humana. Quanto à solidariedade, envolve disposição de cooperação com os demais membros da comunidade, numa perspectiva que transcende o âmbito individual em prol do social, cuja influência se faz sentir na atual concepção da boa-fé" (CAMILA PACíFICO, O princípio da boa fé, p. 154). No mesmo sentido: "Nestes quadros, o princípio da boa-fé, como resultante necessária de uma ordenação solidária das relações intersubjetivas, patrimoniais ou não, projetada pela Constituição, configura-se, muito mais do que como fator de compreensão da autonomia privada, como um parâmetro para a sua funcionalização à dignidade da pessoa humana, em todas as suas dimensões." (TERESA NEGREIROS, Fundamentos para uma interpretação constitucional do princípio da boa fé, p. 223).
} 
emanada no convívio social. Em princípio são vagos, mas se afirmam relevantes justamente por sua amplitude. A concretização deles faz-se por meio da atividade jurisprudencial e identificação, no caso concreto, da confiança a ser tutelada, o que não representa aceitação do arbítrio; pelo contrário, tais valores servem como critério de decisão e, ao mesmo tempo, são concretizados por meio das decisões judiciais, o que lhes confere a natureza de princípio $^{182}$.

Ademais, como já apresentado anteriormente, certo é que a atividade legislativa não consegue dar conta de regular a priori todos os conflitos que podem surgir na sociedade, motivo pelo qual é relevante a presença de conceitos abertos, a serem preenchidos pela aplicação do direito no caso concreto. Nesse contexto, o venire é instrumento útil à concretização de valores, pois, delimitados os seus pressupostos, a cada vez em que é aplicado torna tangível a proteção abstrata de que os princípios se encarregam.

ANDERSON SCHREIBER chama atenção para o fenômeno da "superutilização da boa-fé”, aplicação sem critério do princípio, invocado para tudo solucionar, o que faz com que a boa-fé acabe "por correr o risco de se converter em um conceito vazio, inútil mesmo na consecução daqueles fins que tecnicamente lhe são próprios" ${ }^{\text {183 }}$. Para evitar esse tipo de situação, institutos mais concretos são essenciais, demonstrando-se assim mais uma utilidade da aplicação do princípio do nemo potest venire contra factum proprium.

O fato de serem diversas as fundamentações do princípio da vedação ao comportamento contraditório não enfraquece sua teorização; ao contrário, permite sua aplicabilidade em diferentes situações - não só num contexto negocial, mas também em outras áreas do Direito Civil e em outros ramos do Direito - e confirma a autonomia do instituto, pois, se ele se relaciona com diversos princípios, é certo que ele não se identifica por inteiro com nenhum deles ${ }^{184}$.

\footnotetext{
${ }^{182}$ A ideia é bem elaborada por TERESA NEGREIROS. A autora afirma: "[Vislumbramos] na falta de precisão que marca o termo 'princípio', ao invés de um mal a ser corrigido, um componente de sua significação, especificamente a multifuncionalidade sistêmica dos princípios, ligada a uma nova maneira de pensar a ordenação sistemática do tecido normativo. (...) Conclui-se, portanto, que os princípios são, ao mesmo tempo, causa e consequência da interpretação, na medida em que a função interpretativa que desempenham é, ela própria, resultado de uma interpretação sistemática segundo a qual um dado preceito normativo é funcionalizado como um princípio em um ordenamento jurídico" (Fundamentos para uma interpretação constitucional do princípio da boa fé, pp. 107-126).

${ }^{183}$ ANDERSON SCHREIBER, A proibição de comportamento contraditório, p. 123.

${ }^{184}$ ANDERSON SCHREIBER conclui que a referência à solidariedade social é fundamental para garantir que a aplicação do venire não se restrinja aos contextos negociais em que comumente a boa-fé é associada. Ao
} 


\subsection{Efeitos jurídicos}

Fixado o conceito do que se entende por nemo postet venire contra factum proprium, seus pressupostos e o embasamento legal para sua aplicabilidade, resta dissertar sobre seus efeitos, qual a repercussão fática quando identificada uma situação em que deve incidir o venire.

A primeira e mais evidente consequência é o impedimento do comportamento contraditório (função impeditiva): tendo em vista a finalidade de tutelar a confiança, a aplicação do venire deve, desde logo, buscar a efetivação das expectativas geradas, o que se garante ao evitar que a conduta contraditória seja eficaz. Somente assim pode se atingir a máxima proteção à confiança tutelada ${ }^{185}$, sendo essa a situação ideal, pois, atuando-se preventivamente, evita-se a instauração de um conflito que pode ser longo e custoso para as partes.

Nesse ponto, uma ressalva parece pertinente: já sustentamos que, para a configuração do venire, fundamental a prática de um primeiro ato, do qual sejam emitidas expectativas que são posteriormente feridas pela prática de um segundo ato, contraditório ao primeiro. Assim, impossível o impedimento da prática do segundo ato em si, pois, do contrário, sequer restaria configurado o venire. Ao mencionarmos a função impeditiva, deve se entender que as consequências jurídicas do segundo ato são desconsideradas, tal como nunca houvesse sido praticado ${ }^{186}$, ou seja, obstam seus efeitos.

Não se trata da perda do direito em si, mas apenas sua ineficácia diante de determinadas circunstâncias ${ }^{187}$. Em outras palavras, a teoria dos atos próprios visa a

possuir um fundamento constitucional direto, garante-se a incidência do venire nas diversas áreas do Direito (A proibição do comportamento contraditório, p. 120-121).

185 ANDERSON SCHREIBER, A proibição de comportamento contraditório, p. 164.

186 "El efecto fundamental que provoca la aplicación de la doctrina es la irrelevancia de la conducta contradictoria con un acto anterior, esto es, que el acto posterior contradictorio no se tiene en cuenta, y se está a la primeira manifestación” (MARCELO MESA e CARLOS VIDE, La doctrina de los actos propios, p. 147).

${ }^{187}$ DíEZ-PICAZO, La doctrina de los propios actos, p. 246. Quanto à impossibilidade de o venire significar a perda do direito propriamente dito $c f$. as páginas 163-164 da mesma obra, em que o autor diferencia o venire de renúncia tácita. Trata-se de figuras distintas porque, em síntese, a renúncia tácita impõe a análise da vontade que é obtida por comportamentos incompatíveis com a continuidade do direito subjetivo, ao passo que o venire prescinde de qualquer análise volitiva. Além disso, os efeitos são diferentes: a renúncia gera a extinção do direito subjetivo, ao passo que o venire o torna inadmissível em determinadas circunstâncias, e ainda, são suscetíveis de venire quaisquer direitos, e não somente os renunciáveis/disponíveis, limitação que a renúncia tácita possui. No mesmo sentido, PUIG BRUTAU, Estudios de derecho comparado, p. 102. 
impedir que o segundo ato produza efeitos jurídicos, pelo fato de, naquele contexto em que praticado, representar ruptura da confiança gerada. Entretanto, considerando o que já foi exposto sobre a necessária licitude do ato próprio e do ato contraditório, nada impede que esse segundo ato seja praticado em contexto diverso, desde que não represente afrontas a expectativas.

Todavia, nem sempre é possível atuar de modo preventivo: há casos em que o Judiciário é procurado tardiamente, após a ocorrência do dano, ou ainda, é possível vislumbrar situações em que o ato contraditório não pode ser obstado, sob pena de serem afrontados outros princípios, de modo que se permite a contradição ${ }^{188}$, e opta-se por compensar aquele que teve as expectativas frustradas posteriormente.

Daí então se exerce a função reparatória. Alguns entendem que essa função é decorrente da regra geral de que todo dano gerado injustamente deve ser ressarcido e, de fato, há decorrências desse pensamento, mas, considerando-se que o ato contraditório seria inicialmente lícito, e somente por força da aplicação do venire torna-se ilícito, a configuração do instituto é imprescindível para gerar responsabilidade.

Por fim, considerando-se a tendência atual de satisfação do direito do modo mais próximo possível como se ele nunca houvesse sido violado (execução específica), é possível cogitar a imposição de desfazimento da conduta contraditória e responsável por ter lesado as expectativas alheias. Assim preceitua o art. 251 do Código Civil ${ }^{189}$, raciocínio a ser aplicado também nos casos de venire contra factum proprium ${ }^{190}$.

Para a aplicação desses efeitos, existe a possibilidade de a teoria da vedação a comportamentos contraditórios ser reconhecida pelo próprio juiz, independentemente de pedido das partes nesse sentido.

Apesar de entendimentos contrários ${ }^{191}$, concordamos com aqueles que defendem a aplicação da teoria a despeito do requerimento das partes ${ }^{192}$. Mas uma ressalva merece ser feita: como estamos estudando a manifestação do venire no âmbito do direito

\footnotetext{
188 Como exemplo, expõe ANDERSON SCHREIBER que: "De fato, não pode o direito privado coagir fisicamente quem quer que seja a se abster de certa conduta; e se tal coação física não é autorizada no âmbito dos atos normalmente vinculantes (negócio jurídico), não pode ser autorizada também no âmbito do venire contra factum proprium" (A proibição de comportamento contraditório, p. 165).

189 Art. 251. Praticado pelo devedor o ato, a cuja abstenção se obrigara, o credor pode exigir dele que o desfaça, sob pena de se desfazer à sua custa, ressarcindo o culpado perdas e danos.

${ }^{190}$ JuDITH MARTINS-COSTA, A ilicitude derivada do exercício contraditório de um direito, p. 127.

${ }^{191}$ PAUlo Mota PINTO, Sobre a probição do comportamento contraditório no direito civil, p. 168.

192 Marcelo Mesa e CARlos Vide, La doctrina de los actos propios, p. 148 e ANA I. PiAgGi, Reflexiones sobre dos princípios basilares del derecho: La buena fe y los actos próprios, p. 116.
} 
privado, faz-se fundamental que a parte que teve as expectativas feridas pela contradição dos atos praticados por outrem manifeste sua insurgência, relatando os fatos a partir dos quais o magistrado poderá extrair os elementos configuradores da teoria.

Em outras palavras, não é possível que o juiz depreenda, de ofício, a ruptura da confiança gerada se nenhuma indignação do frustrado é identificada - como os fatos se deram fora do processo, sem qualquer notícia deles pelas partes o juiz não teria como tomar conhecimento da contradição. O que frequentemente pode ocorrer é que tal indignação não é relatada tal como hipótese de venire, mas, aí sim, considerando o princípio iura novit curia, cabe ao magistrado subsumir os fatos ao princípio da vedação de comportamentos contraditórios.

E esse reconhecimento pelo juiz pode considerar condutas processuais e extraprocessuais, bastando que isso seja feito pela via processual, o que não se confunde com a necessidade de as condutas serem exercidas no curso de um processo ${ }^{193}$. É o que ressalta ALEJANDRO BORDA, para quem a incoerência não precisa se dar perante o juízo, pois há casos de venire baseados em condutas extrajudiciais, provocadas inclusive antes do início do processo ${ }^{194}$.

Assim, não encontramos na doutrina civilista uma diferenciação entre venire processual ou material, indagando-nos em que medida é possível a realização desta distinção, o que será abordado adiante.

\footnotetext{
193، Una cosa es que se requiera un proceso para invocar la violación de la obligación de coherencia, generalmente como defensa, sometiendo la decisión de la cuestión a un tercero impacial, opinión que comparto, y otra, muy distina, es que sólo pueda invocarse la violación de la regla respecto de conductas o actos procesales y no extrajudiciales, criterio del que no participo" (MARCElo Mesa e CARLOS VIDE, La doctrina de los actos propios, p. 125). Da mesma maneira, afirma DíEZ-PICAZO que: "Lo que tiene que existir, de esto no cabe como luego veremos más detenidamente, es una situación litigiosa porque precisamente en la situación litigiosa es donde se produce la contradicción y la alegación de la inadmisibilidad de contradecirse" (La doctrina de los propios actos, p. 207).

${ }^{194}$ ALEJANDRO BORDA, La teoria de los actos propios, p. 129.
} 


\section{OS COMPORTAMENTOS PROCESSUAIS}

Pelo que já expusemos no que se refere à aplicação da teoria da vedação ao comportamento contraditório em âmbito civil, vê-se que a conduta assume papel fundamental, seja quando do exercício do factum proprium, seja na ocorrência do comportamento posterior contraditório. Por isso, imprescindível ao nosso estudo estabelecer algumas premissas concernentes aos comportamentos processuais, para que, ao final, seja possível averiguar quais deles podem dar ensejo à reprimenda da contradição no campo processual (o que será feito no item 8.2 infra). E estudar comportamentos processuais significa compreender as situações jurídicas processuais.

Prescindível ao nosso estudo, porém, a exposição das diferentes teorias sobre o que se entende por processo e sua natureza, bastando afirmar, tal como HELENA ABDO ${ }^{195}$, que todas elas admitem a noção de situações jurídicas processuais, que nada mais são do que momentos da relação jurídica processual, que, sendo complexa e dinâmica ${ }^{196}$, progride justamente com o exercício de condutas pelos sujeitos processuais.

Em outras palavras, as situações jurídicas processuais são as condutas praticadas (ou potencialmente praticadas) pelos sujeitos processuais no curso do procedimento $^{197}$. As normas processuais atribuem aos sujeitos do processo a possibilidade de praticarem determinadas condutas, sendo justamente "a posição na qual se encontra um sujeito que detém todas as condições para a eventual prática de um ato ou exercício de um comportamento" ${ }^{\text {198 }}$ o conceito de situação jurídica processual.

Considerando as funções diversas assumidas pelas partes e pelo juiz no processo, é natural que as suas posições jurídicas sejam distintas, já que possuem interesses diferentes no decorrer do processo: enquanto as partes atuam conforme interesses próprios, o juiz age em prol do interesse público ${ }^{199}$. Isso justifica o estudo em separado das situações jurídicas das partes e do juiz, o que inclusive se faz pertinente para que se compreendam

\footnotetext{
${ }^{195}$ HelENA ABDO, Abuso do processo, p. 58.

${ }^{196}$ HELENA ABDO, As situações jurídicas processuais e o processo civil contemporâneo, p. 339.

${ }^{197}$ Pedro DinAmARCO, Ônus processuais, p. 12.

${ }^{198}$ HeLENA ABDO, Abuso do processo, p. 61.

${ }^{199}$ HeITOR VITOR MENDONÇA SICA, Preclusão processual civil, p. 266.
} 
posteriormente as diferenças da adoção de comportamentos contraditórios por cada um desses sujeitos.

\subsection{Situações jurídicas processuais das partes}

Dentre as possíveis condutas atribuídas às partes pelas normas processuais, distinguem-se as ativas das passivas. As primeiras são aquelas que colocam o sujeito em posição de vantagem, permitindo-o agir conforme seu interesse, sendo-lhe sempre favorável $^{200}$. As passivas, por sua vez, impõem a realização de conduta ou aceitação de ato favorável a outrem, representando um sacrifício ao sujeito ${ }^{201}$.

\subsubsection{Situações processuais ativas: faculdades e poderes ${ }^{202}$}

A faculdade processual é mais bem definida como a situação jurídica de vantagem que se exaure na esfera jurídica do próprio agente ${ }^{203}$, ou seja, gera vantagens ao agente, sem repercussões em esferas jurídicas de terceiros. Assim, a faculdade não corresponde à prática de um ato que não representa nenhuma vantagem, vez que, se assim fosse, sequer haveria motivos para ser exercido ${ }^{204}$. Pelo contrário, há vantagem percebida pelo agente, ainda que seja a mera conveniência, o que é irrelevante a terceiros por não gerar qualquer implicação na esfera de seus direitos.

${ }^{200}$ CÂNDIDo Dinamarco, Instituições de Direito Processual Civil, v. II, p. 206.

201 Pedro Dinamarco, Ônus processuais, p. 33; HeITOR VITOR MENDONÇA SICA, Preclusão processual civil, p. 97.

${ }^{202}$ Em breve síntese, importante esclarecer que optamos por aderir às ideias dos processualistas que entendem inexistirem "direitos subjetivos" processuais, porquanto o conceito de "direito subjetivo" proveniente do Direito Civil pressupõe necessariamente a relação existente entre um bem e um titular ao qual o bem é colocado à disposição, ao passo que no Processo Civil não há atuação concreta sobre bem algum. Assim, o "poder" retrata melhor a situação ativa processual correlata ao direito subjetivo, principalmente porque pelo conceito de "poder" já se depreende uma relação instrumental para realização de direitos, o que melhor se coaduna com o processo e com as posições ativas das partes que têm por função instrumental influenciar o resultado final. Nesse sentido, $c f$. PAUlA COSTA E SILVA, Acto e processo, pp. 131-138; CÂNDIDo Dinamarco, Instituições de Direito Processual Civil, v. II, pp. 215-216.

${ }^{203}$ HELENA ABDO, As situações jurídicas processuais e o processo civil contemporâneo, p. 346.

204 “Afinal, seria muito difícil imaginar que algum ato não repercutisse em nada na esfera jurídica própria, ou no desenrolar da atividade processual. Se houvesse algum ato assim, não teria razão alguma de ser praticado." (HEITOR VITOR MENDONÇA SICA, Preclusão processual civil, p. 98). 
A faculdade está intrinsecamente ligada à liberdade: o sujeito legitimado tem ampla liberdade de exercer ou não determinada situação jurídica processual, o que a qualifica como faculdade: "O ato facultativo é juridicamente permitido e não é obrigatório" ${ }^{205}$, de modo que, optando por não exercer determinada faculdade, o sujeito não perde nada, não gera nenhuma desvantagem a si mesmo.

A raridade com que as faculdades processuais aparecem não está no fato de que dificilmente existem atos processuais que não gerem vantagem alguma (já que a faculdade, como já afirmado, gera, sim, uma vantagem, ainda que seja a simples conveniência de praticar um ato de determinada forma em detrimento de outra), mas sim pela razão de que dificilmente o exercício de uma situação jurídica processual deixa de gerar repercussões a terceiros, dada a dialeticidade intrínseca ao processo.

Exemplos recorrentes na doutrina são: a faculdade de interpor recurso no primeiro ou último dia de vencimento do prazo ou a faculdade de praticar o ato em forma livre, se não exigida maneira específica (art. 154 do CPC) $)^{206}$.

Também uma posição jurídica de vantagem, o poder se difere da faculdade porquanto seu exercício influencia a esfera jurídica de terceiros, gerando deveres a outrem, seja à parte adversa ${ }^{207}$, seja ao Estado-juiz. Trata-se de situações jurídicas de vantagem, decorrentes diretamente de lei ou, de maneira indireta, dos princípios processuais ${ }^{208}$, e que, uma vez exercidas, não só geram a vantagem ao detentor do poder, mas também geram uma sujeição a outrem.

É certo que, em um primeiro momento, a opção por exercer ou não um poder representa uma faculdade da parte. Mas não se trata da faculdade a que nos referimos, ou, nas palavras de DiNAMARCO, não é uma faculdade pura ${ }^{209}$, porquanto a escolha por exercêlo acarretará influência à esfera jurídica alheia, revelando-se, assim, a peculiaridade do poder. De todo modo, também a escolha pelo exercício ou não de um poder envolve um espaço de liberdade da parte.

\footnotetext{
205 ANTONIO Do PASso CABRAL, Nulidades no processo moderno, p. 166.

${ }^{206}$ HELENA ABDO, Abuso do processo, pp. 65-66.

${ }^{207}$ Diz-se que as partes somente têm poderes em face do Estado, de modo que o poder de recorrer, contestar ou reconvir, por exemplo, seja oponível diretamente somente ao órgão judicial ( $c f$. PEDRO DINAMARCO, Ônus processuais, p. 30). Entretanto, entendemos que inegavelmente o exercício do poder significa, ainda que indiretamente, influenciar a esfera jurídica do adversário, agravando-a.

${ }^{208}$ PEDRO DinAMARCO, Ônus processuais, p. 30.

${ }^{209}$ CÂndido Dinamaro, Instituições de Direito Processual Civil, p. 211.
} 


\subsubsection{Situações processuais passivas: deveres, ônus e sujeição}

Os deveres caracterizam-se porque exercidos no interesse alheio, apenas. É, assim, a situação jurídica processual passiva que se destaca pela exigência de uma conduta ou uma omissão no interesse de outrem, sob pena da imposição de sanções. Tratando-se de deveres processuais, o interesse alheio corresponde, em verdade, aos interesses de uma adequada realização do processo $^{210}$.

Recorrente na doutrina a afirmação de que são poucos os deveres processuais das partes $^{211}$, porquanto, como se verá, os ônus acabam sendo mais eficientes para impulsionar o processo, servindo de estímulo à necessidade de praticar certos atos processuais a fim de afastar a incidência de uma desvantagem. São destacados como principais exemplos de dever o de agir conforme a lealdade e a boa-fé, servindo os deveres processuais para impor padrões de comportamento aos sujeitos processuais ${ }^{212}$.

Conforme afirmado, o exercício dos deveres é imposto majoritariamente no interesse público, do que decorre a perda da liberdade em não exercê-lo: o não exercício implica aplicação de sanção, já que o dever é exigido no benefício de todos ${ }^{213}$. Paralelamente, considerando ser uma imposição da qual o agente não consegue se esquivar, é preciso que lhe seja garantido o direito de exercer o dever ${ }^{214}$.

Os ônus, situações mais abundantes no processo civil, são aquelas posições jurídicas processuais que requerem o exercício de um ato processual a fim de se evitar um prejuízo ao agente ou para que ele obtenha uma vantagem, sendo classicamente definidos como um "imperativo de próprio interesse" 215.

\footnotetext{
${ }^{210}$ EDUARDO COUTURE, Fundamentos del derecho procesal civil, p. 209.

${ }^{211}$ PEDRo DINAMARCO, Ônus processuais, p. 42; CÂNDIDO DINAMARCO, Instituições de Direito Processual Civil, v.II, p. 214.

${ }^{212}$ Paula Costa e Silva, Acto e processo, p. 144.

213 JOAN PICÓ I JUNOY, El principio de la buena fe procesal, pp. 131-132; ROGÉRIA DOTTI DORIA, A litigância de má-fé e a aplicação de multas, p. 648.

${ }^{214}$ 'Deveres (ou obrigações) correspondem a uma restrição à vontade: são expressões de 'não liberdade', estabelecidos por normas impositivas ou proibitivas. Mas o dever tem que ser acompanhado do direito de praticar atos em cumprimento da obrigação. Assim, a parte que tem um dever tem também o direito de cumpri-lo, sob pena de o dever deixar de existir por não haver meios para adimplir" (ANTONIO DO PASSO CABRAL, Nulidades no processo moderno, p. 167).

215 "Aparte de esto [de poucos casos de deveres processuais], sólo existen en el proceso 'cargas', es decir, situaciones de necesidad de realizar determinado acto para evitar que sobrevenga un perjuicio procesal. Con otras palabras, se trata de 'imperativo del propio interés'”. (GOLDSCHMIDT, Derecho procesal civil, p. 203).
} 
A supremacia dos ônus em relação aos deveres, segundo LENT, não está na incompatibilidade dos deveres com a natureza do processo, mas em razão de, em primeiro lugar, as consequências decorrentes da não desincumbência de um ônus serem mais gravosas do que a simples imposição de penas processuais e, em segundo lugar, porquanto os ônus contribuem de maneira mais eficaz para a celeridade do processo: o procedimento necessário a constranger alguém à realização de um dever é mais complexo e demorado ${ }^{216}$.

E conclui o autor que, para que não haja confusão, sempre que a lei conferir a faculdade ao sujeito de determinar seu próprio comportamento, estamos diante de um ônus; já se ela desaprova uma determinada conduta, trata-se de um dever, independentemente de eventual ausência de meios coercitivos expressos ${ }^{217}$.

Essas ideias são mais bem complementadas pelas observações de HEITOR ViTOR MENDONÇA SICA, ao afirmar que ônus e deveres não se confundem por quatro motivos principais: (i) no ônus não há sujeição a uma obrigação, mas a consequência negativa é apenas a não obtenção de vantagem; (ii) essa consequência só se verifica quando e se o direito não é exercido, ao passo que no dever a desvantagem existe independentemente do exercício - há sempre a sujeição; (iii) no dever, inexiste interesse próprio, e esse é o motivo para explicar porque o ônus, tendo em vista o interesse próprio a ele interente, permite liberdade de escolha para exercer ou não a conduta; (iv) o inadimplemento do ônus gera sua perda, ao passo que, no dever, isso não acontece: "mesmo em face da omissão do agente, o sistema continua querendo dele o adimplemento do dever, e o sujeito continua obrigado a observá-1o"218.

Nota-se, assim, que é inerente à figura do ônus a ligação com a faculdade, com a liberdade de agir. Não é à toa que se afirma que a prevalência dos ônus processuais em detrimento de outras situções jurídicas é reflexo da garantia constitucional da liberdade aplicada ao processo ${ }^{219}$.

Intrinsecamente ligado ao conceito de ônus está, também, o interesse público. Esse é o elemento responsável por inserir o risco da desvantagem uma vez não

\footnotetext{
${ }^{216}$ FRIEDRICH LENT, Diritto processuale civil tedesco, p. 105.

${ }^{217}$ Nas palavras do autor: "La distinzione tra oneri e doveri deve essere compiuta tenendo presente l'intima natura delle situazione studiate. Se la legge concede alla parte la facoltà di determinare il proprio attenggiamento, siamo di fronte ad un semplice onere; se invece mostra di disapprovare un determinato contegno, siamo in presenza al dovere di tenere uno contrario: e non ha rilievo l'eventuale mancata previsione di mezzi coercitivi." (FRIEDRICH LENT, Diritto processuale civil tedesco, p. 105).

${ }_{218}$ HeITOR Vitor MENDONÇA SICA, Preclusão processual civil, p. 103.

${ }^{219}$ Pedro DinAmarCo, Ônus processuais, p. 42.
} 
desincumbido o ônus; é com base nele que um comportamento é tido como necessário e, a fim de estimulá-lo, cria-se o imperativo de próprio interesse ${ }^{220}$.

Ressalte-se, entretanto, que é elemento necessário para caracterizar o ônus apenas o risco de prejuízo em caso de sua inobservância, mas não que esse prejuízo necessariamente ocorra no caso concreto. Como exemplo, basta pensar no ônus da prova do réu que, uma vez não desincumbido, não leva necessariamente ao julgamento de procedência em favor do autor, seja porque as alegações deste foram inverossímeis, seja porque não suficientemente comprovadas ${ }^{221}$.

Além da relação entre ônus e faculdade e da diferenciação entre ônus e dever, é preciso distiguir o ônus do poder. Em verdade, por meio da previsão dos ônus, estimula-se o exercício do poder. Porém, com ele não se confunde pura e simplesmente porque uma vez não exercido o ônus, há consequências negativas ao agente, o que não se observa na noção pura de poder $^{222}$.

Ainda com relação ao ônus, vale apontar, sem necessidade de aprofundamento da questão, a existência da discussão se correto afirmar que o ônus é, de fato, uma situação jurídica processual passiva. DINAMARCO afirma se tratar de figura intermediária, porque, em verdade, os ônus são cumpridos no interesse do titular (o que o assemelha a uma posição de vantagem), porém sob a ameaça de um prejuízo em caso de descumprimento (o que permite sua qualificação como situação passiva) ${ }^{223}$. Há quem entenda, porém, ser uma situação jurídica ativa, porquanto o que caracteriza o ônus é o que lhe é lícito fazer, e não a consequência negativa em caso de descumprimento, encargo imposto por outra norma ${ }^{224}$.

Por fim, é preciso destacar a sujeição, posição jurídica passiva consubstanciada na necessidade de obedecer ${ }^{225}$. Pela sujeição, o sujeito processual não tem opção que não acatar o exercício de posição jurídica de outrem e respeitar suas consequências, sem que, para tanto, dependa-se de qualquer conduta desse sujeito passivo ${ }^{226}$. Exemplo disso é o do

\footnotetext{
${ }^{220}$ PEDRo DinAmarco, Ônus processuais, p. 45.

${ }^{221}$ É com base na inevitabilidade (ou não) de o prejuízo incidir uma vez não observado o ônus que se formulou a diferenciação doutrinária entre ônus absolutos e relativos, $c f$. CÂNDIDO DINAMARCO, Instituições de Direito Processual Civil, v. II, p. 210.

${ }_{222}^{22}$ Pedro Dinamarco, Ônus processuais, p. 53.

${ }^{223}$ CÂNDIDo Dinamarco, Instituições de Direito Processual, v. II, p. 206. No mesmo sentido, HeITOR VITOR MENDONÇA SICA, Preclusão processual civil, p. 102.

${ }^{224}$ PEDRo NogueIRA, Situações jurídicas processuais, p. 764.

225 ANTONIO DO PASSO CABRAL, Nulidades no processo moderno, p. 167.

${ }^{226}$ Para PAUla COSTA E SILVA, é a posição na qual "o interesse do titular da situação activa satisfaz-se simplesmente através do exercício do poder em que se encontra investido. A parte que se encontra em estado de sujeição vê-se totalmente privada da liberdade de agir" (Acto e processo, p. 157).
} 
réu com relação ao exercício do direito de ação do autor, que nada pode fazer para impedir esse exercício e sua figuração como parte uma vez instaurado o processo. O resultado final deste é independente, podendo-se chegar ao fim do processo sem qualquer colaboração do polo passivo da demanda ${ }^{227}$.

\subsubsection{Omissão}

Como anteriormente afirmado, a situação jurídica processual corresponde à atribuição de uma possível conduta ao sujeito do processo. São, portanto, situações comissivas. Toda vez que um sujeito processual deixar de exercer uma situação jurídica processual, tem-se a omissão, que, portanto, pode ser decorrente de um não-exercício de um poder, uma faculdade, um dever ou um ônus - excluindo-se apenas a sujeição, por óbvio, vez que ela mesma representa uma omissão.

Encontra-se na doutrina a referência de que, sendo a omissão um nada, um não-comportamento, ela somente adquire relevância jurídica quando existente uma exigência de um comportamento positivo, o que, no processo, traduz-se pela situações de ônus e de deveres processuais ${ }^{228}$. Dessa maneira, a omissão diante de um dever implica a incidência de sanções - o que, como vimos, não é realidade tão frequente no processo, dada a restrição do número de deveres -, ao passo que a não desincumbência de um ônus pode gerar consequências desfavoráveis.

Todavia, a omissão das posições jurídicas de vantagem pode gerar consequências processuais, o que ANTONIO DO PASSO CABRAL denominou de "omissão conclusiva"229. Segundo o autor, que analisa o tema sob o enfoque da repercussão da omissão no sistema de nulidades, além das omissões cuja consequência negativa já está expressamente prevista pelo ordenamento - diante da expectativa da prática de comportamento comissivo, tal como ocorre nas omissões de deveres e ônus -, as omissões

\footnotetext{
${ }^{227}$ PAUla COSTA E Silva, Acto e processo, p. 158.

${ }^{228}$ CÂNDIDO DINAMARCo afirma que: "Pelo aspecto puramente histórico-descritivo, toda omissão é um nada, é algo que não aconteceu. Perante o direito, esse vazio histórico passa a ser relevante quando a conduta que se omitiu era exigida por algum imperativo de conduta, ou seja, são juridicamente relevantes as omissões de atos que o sujeito tivesse o dever ou o ônus de realizar" (Instituições de Direito Processual Civil, v. II, p. 486).

${ }^{229}$ Nulidades no processo civil moderno, p. 328.
} 
de posições de vantagens também são capazes de adquirir relevância normativa, desde que sejam omissões qualificadas por requisitos específicos.

E essa qualificação é justamente que a omissão tenha gerado expectativas de que a situação de vantagem não mais seria praticada. Como se trata de posição de vantagem, a não realização do ato não implica nenhuma nulidade ou preclusão per si, "mas se torna vinculante quando cria uma expectativa para outros sujeitos de manutenção daquele comportamento anterior", de modo a não mais se permitir a realização daquele ato $^{230}$.

Veremos o funcionamento e repercussão dessas omissões conclusivas no item 8.2.1.2. infra. Por ora, basta fixarmos a premissa de que não só as omissões de ônus e deveres geram consequências jurídicas, pois, ainda que de maneira bem mais restrita, a omissão de posições de vantagens também podem gerar consequências ${ }^{231}$.

\subsection{Situações jurídicas processuais do juiz}

\subsubsection{Poderes-Deveres}

É quase uníssona a referência na doutrina de que os juízes possuem poderesdeveres $^{232}$, apenas. Assim, além de não serem titulares de faculdades e ônus, a própria natureza dos poderes e deveres a eles inerentes possuem contornos diversos dos poderes e deveres das partes.

Considerando que as faculdades estão intimamente ligadas à liberdade, à possibilidade de disposição de bens e situações jurídicas conforme o interesse de seu

\footnotetext{
${ }^{230}$ ANTONIO DO PASSO CABRAL, Nulidades no processo civil moderno, p. 332.

${ }^{231}$ Em princípio, a omissão de um ônus poderia configurar uma omissão conclusiva na medida em que o ônus se situa nessa zona cinzenta entre posição jurídica de vantagem e de desvatagem. Todavia, explicaremos no item 8.2.1.2. infra, isso não é possível na medida em que o sistema já disciplina a omissão do ônus com a preclusão, sem necessidade de se falar em venire, dado o seu caráter de subsidiariedade.

${ }^{232}$ HeITOR VITOR MENDONÇA SICA, Preclusão processual civil, p. 105; CÂNDIDO DinamarCO, Instituições de Direito Processual Civil, v. II, pp. 211-212. Ainda que se utilize do termo "facultad" ao invés de "poder", o sentido empregado por ADOLFO Velloso é o mesmo: "Por nuestra parte, nos atenemos a la denominación utilizada por la ley de rito, entendiendo por deber, el imperativo jurídico que ordena una conducta positiva o negativa del juez, cuya omisión lo hará pasíble de algún tipo de sansión o responsabilidad (administrativa, civil o penal); y por facultad, la aptitud, poder o derecho para haver alguna cosa u obrar en determinado sentido, cuyo ejercicio está encaminado al mejor desempeño de la función" (El juez: sus deberes y facultades, p. 9).
} 
titular, logo se vê a incompatibilidade dela com as funções exercidas pelo juiz, que atua no processo como personificação do Estado e de seus interesses. Em outras palavras, o juiz não tem interesses próprios a tutelar por meio do processo $^{233}$, de modo que eventual liberdade de escolha por atuar ou não seria não só irrelevante como contrária à sua função: ele nada pode escolher em nome da sua simples conveniência porquanto não atua conforme sua vontade.

Daí a importância dos poderes como a situação jurídica ativa destinada ao juiz. Por meio desse exercício o juiz consegue cumprir suas funções, consegue garantir que sejam atingidos os escopos da jurisdição ao decidir o caso concreto e imperativamente fazer observar essa decisão, produzindo efeitos sobre a esfera jurídica das partes ${ }^{234}$. E, para que se chegue à solução final, são concedidos diversos poderes ao juiz, tais como o de direção sobre o processo, o de instrução, o de julgamento propriamente dito, o de imposição de efeitos desse julgamento, os quais, por sua vez, desdobram-se em muitos outros poderes, como o de indeferir uma inicial inepta, decidir pela produção ou não de determinada prova, entre tantos outros.

É claro que, diante do necessário equilíbrio entre o interesse do Estado e as garantias das partes, os poderes dos juízes encontram limites na legislação processual. Talvez o principal deles seja a impossibilidade de dar início ao processo de ofício, bem como de julgar sem observar o princípio da adstrição, havendo necessária correlação entre o objeto do processo delimitado pelas partes e o objeto a ser enfrentado quando do julgamento (artigos 2, 262 e 460 do CPC) ${ }^{235}$.

Mais evidente ainda é a inexistência de ônus para o juiz: o agente do Estado, que atua no interesse público, não se sentiria estimulado a praticar atos processuais sob pena de lhe incindir uma desvantagem, já que nenhum interesse próprio do magistrado é relevante na relação jurídica processual. "O Estado-juiz nada ganha e nada perde no processo, conforme o resultado da causa. Os interesses postos sob seu zelo e tutela não são seus, mas das partes. ${ }^{, 236}$.

O estímulo que o juiz encontra para o exercício de sua função, portanto, não está nos ônus, e sim nos deveres. Ao assumir a função de representante do Estado no

\footnotetext{
${ }^{233}$ ANTONIO DO PASSO CABRAL, Nulidades no processo moderno, p. 333.

${ }^{234}$ CÂNDIDO DinAMARCO, Instituições de Direito Processual, v. II, pp. 211-212.

${ }^{235}$ PEDRO DINAMARCO, Ônus processuais, p. 29.

${ }^{236}$ CÂNDIDO DinamarCo, Instituições de Direito Processual, v. II, p. 214.
} 
exercício da jurisdição, é natural que sempre atue no interesse do Estado, o qual lhe impõe uma série de deveres para o controle das atividades jurisdicionais ${ }^{237}$.

Daí a afirmação de que as situações jurídicas processuais do juiz são os poderes-deveres.

Isso, contudo, não exclui a existência de uma liberdade de atuação do magistrado no exercício de suas funções jurisdicionais, ainda que essa liberdade seja manifestamente menor do que a liberdade das partes, as quais possuem situações jurídicas processuais mais amplas e menos vinculadas às restrições legais.

Nesse ponto, fundamental diferenciar discricionariedade de liberdade interpretativa: tem-se por discricionariedade a possibilidade de coexistirem duas ou mais soluções igualmente legítimas, sendo possível a escolha livre por uma delas, sem chances de revisão ou alteração ${ }^{238}$. Com base nessa premissa, entende-se que o órgão julgador não possui discricionariedade, já que o ordenamento jurídico determina a busca pela única solução possível ao caso concreto, qual seja, aquela "desejada pelo legislador e 'determinada' pela norma, ainda que o caminho para que se chegue até ela não seja dos mais fáceis" ${ }^{239}$.

Dessa maneira, ainda que uma decisão judicial possa ser alterada por um órgão superior, isso se dá justamente porque pode haver diferenças quanto ao que se interpreta como a única solução possível, mas, ao longo de todo exercício da atividade jurisdicional, busca-se aquela decisão única, e predominará apenas uma única decisão, sem possibilidade de convivência harmônica com mais opções igualmente aceitáveis.

As diferenças de interpretação, por sua vez, são permitidas pelo sistema. Não se pode negar o subjetivismo intrínseco ao julgador, que nada mais é do que um ser humano interpretando a realidade concreta transplantada para os autos de maneira inevitavelmente distorcida. Ao exercer a função interpretativa da lei, o julgador tem liberdade de escolher a única solução possível segundo o seu entendimento. E o fato de esse entendimento ser submetido ao duplo grau de jurisdição já revela a ausência de discricionaridade: atos puramente discricionários, a rigor, não podem sequer ser revistos, já que o conceito pressupõe a possibilidade de escolha conforme conveniência e oportunidade.

\footnotetext{
${ }^{237}$ PedRo DinAmarco, Ônus processuais, p. 53.

${ }^{238}$ José Roberto dos SANTOS BedaQue, Poderes instrutórios do juiz, p. 152.

239 Teresa ARruda AlviM W AMBIER, Existe a “discricionariedade” judicial?, p. 234.
} 
O juiz, por sua vez, não decide segundo sua conveniência e oportunidade; pelo contrário, decide em observância da lei e de maneira fundamentada, garantindo-lhe apenas a liberdade de interpretação nessa subsunção dos fatos à norma, mas sempre de modo a proferir a única decisão possível.

Com base nisso, tem-se que a atuação por meio de poderes-deveres não exclui qualquer liberdade do magistrado. Ao exercer sua atividade decisória, seja enfrentando questões incidentais, seja proferindo sentenças, há liberdade interpretativa, há "espaço de manobra", o que se mostra suficiente para permitir casos, ainda que em menor quantidade diante da menor liberade de atuação em comparação com as situações jurídicas das partes, em que, por meio das decisões tomadas, seja gerada uma confiança a ser protegida, conforme se verá no item 8.2.2. infra.

\subsubsection{Omissão}

Ainda que exista alguma liberdade de atuação do magistrado, principalmente no exercício do poder-dever decisório, é certo que ela é bastante restrita. O juiz age, na maior parte do tempo, em atenção aos seus deveres funcionais, de modo que a omissão no exercício de um poder-dever possa trazer, via de regra, consequências em sede administrativa, apenas.

Todavia, há quem vislumbre a possibilidade de a omissão do julgador trazer consequências diversas, em hipóteses bastante excepcionais, e justamente nos casos em que ele possui liberdade restrita de atuação (o que, para alguns, caracteriza discricionariedade ${ }^{240}$ ). Nesses casos, a não atuação pode gerar a expectativa legítima de que não haverá atuação ulterior.

Exemplo encontrado na doutrina é o da não declaração de vícios formais no despacho saneador. Uma vez não havendo reconhecimento dos vícios já existentes, a inércia estatal passa a ser conclusiva no sentindo de que inexistente qualquer vício efetivamente relevante e, a partir de então, "os demais sujeitos têm o direito de não ver a pronúncia de nulidade no futuro" 241 .

\footnotetext{
${ }^{240}$ ANTONIO DO PASSO CABRAL, Nulidades no processo moderno, p. 335.

${ }^{241}$ ANTONIO DO PASSO CABRAL, Nulidades no processo moderno, p. 335.
} 
Apesar de não concordarmos especificamente com o exemplo dado, porquanto entendemos que o sistema processual não cria expectativas de que o despacho saneador é o último momento em que possível a declaração dos vícios pretéritos, vislumbramos a possibilidade de a omissão do magistrado poder gerar expectativas que não poderão ser simplesmente rompidas, ainda que isso se dê em casos bastante excepcionais.

O tema será mais bem aprofundado adiante. Mas, para que desde logo ilustremos uma situação que se enquadra no que afirmado, pensemos em uma hipótese em que a parte, quando da oposição de embargos à execução, requer o diferimento do pagamento das custas para o final do procedimento, pedido já feito e já deferido em uma medida cautelar conexa, anteriormente ajuizada. O juízo não se manifesta sobre o pedido nos autos dos embargos à execução, e simplesmente dá seguimento ao processo. Essa omissão foi conclusiva no sentido de que acolhido o pedido de diferimento, não sendo possível que, quando da interposição do recurso de apelação pela parte embargante, o juízo julgue-o deserto por ausência de custas.

É certo que, havendo motivos para o juiz entender que não mais necessário o diferimento do pagamento de custas, em razão da alteração da capacidade econômica da parte, ele pode revisar a decisão anterior (já que alterado o suporte fático-probatório sobre o qual ela fora proferida), indeferindo o diferimento. Mas isso jamais sem antes justificar a mudança de posicionamento, equalizando as expectativas das partes, conferindo prazo para que ela passe a recolher as custas devidas.

Assim, apesar de a hipótese ser bastante rara, é possível que a omissão do juiz seja também conclusiva, dando ensejo à vedação de comportamento contraditório ulterior. O que importa, nesse momento, é fixarmos a premissa de que nem sempre a omissão do juiz é também um nada jurídico, ou algo relevante apenas para fins disciplinares.

\subsection{Consequência da inobservância da forma prevista em lei para as situações jurídicas processuais}

Após essa breve exposição quanto às diferentes situações jurídicas processuais atribuídas às partes e ao juiz, é possível vislumbrar o motivo pelo qual defendemos, apoiando-nos nas ideias de HEITOR VITOR MENDONÇA SicA, que a consequência da inobservância da forma exposta em lei para as situações das partes é a inadmissibilidade 
ou ineficácia, ao passo que, no que concerne ao desrespeito de um poder-dever, caracteriza-se a invalidade que tem por possível consequência a nulidade.

Inicialmente, não podemos confundir as consequências naturais do (não) exercício de determinada situação jurídica processual com as consequências anormais: é consequência natural do não exercício de um ônus a possibilidade de incidir uma desvantagem, assim como é consequência natural da não observância de um dever a aplicação de uma sanção. É natural, ainda, que o exercício de uma faculdade não traga repercussões desvantajosas na esfera jurídica alheia, ao passo que nos poderes essa interferência é consequência natural.

Neste item, porém, referimo-nos às consequências anormais, ou seja, aquelas incidentes quando o exercício de uma situação jurídica não se dá conforme a forma prescrita em lei. Nesse ponto, temos que levar em conta que o magistrado atua dentro da estrita legalidade, com restrita liberdade, ao passo que as partes, diferentemente, possuem ampla liberdade, devendo respeitar as formas prescritas em lei, porém, ausente qualquer prescrição, têm liberdade na forma de se conduzir (art. 154 do CPC).

Disso decorre que, agindo o magistrado distintamente do que a lei lhe impõe por meio de seus poderes-deveres, ele estará atuando para além dos limites da legalidade, do devido processo legal. Atuará, pois, em desconformidade com o interesse público, o que caracteriza a invalidade desses atos, possivelmente declarando-se sua nulidade para que outro possa ser praticado no lugar, dessa vez em conformidade com o interesse público ${ }^{242}$.

Já as situações jurídicas processuais das partes, fundadas precipuamente na liberdade e no interesse predominantemente particular, uma vez inobservadas segundo a forma prescrita em lei, não geram nulidades e sim ineficácia: o sistema processual simplesmente retira os efeitos dos atos praticados pelas partes, sem que seja necessária a nova prática do mesmo ato ${ }^{243}$.

Para nós, importante a distinção entre ineficácia e nulidade, aplicável às situações das partes e do magistrado, respectivamente. Essa ideia será utilizada quando da definição das consequências do venire em âmbito processual.

\footnotetext{
${ }^{242}$ Segundo Heitor Vitor Mendonça SiCA "O juiz, no desempenho de seus poderes-deveres, há que respeitar as garantias constitucionais asseguradas a cada cidadão de um Estado de Direito; atende, pois, ao interesse público. $\mathrm{O}$ não atendimento ao modelo prescrito na lei é repudiado pelo sistema, que reputa o ato irregular ou defeituoso inválido, e determina seja ele excluído do mundo jurídico, mediante sua declaração de nulidade (respeitados, evidentemente, os princípios já aludidos, como os da finalidade, do prejuízo, etc.)" (Contribuição ao estudo da teoria das nulidades, p. 193).

${ }^{243}$ HeITOR Vitor MENDONÇA SICA, Preclusão processual civil, pp. 109-110.
} 


\section{AS EXPECTATIVAS NO PROCESSO}

Sem que haja qualquer confiança a ser tutelada no decorrer da relação jurídica processual, não há razão para se cogitar da aplicação do venire no processo, já que a própria finalidade do instituto restaria esvaziada.

A concepção de que o processo é um jogo no qual cada parte se utiliza livremente de suas armas ${ }^{244}$, sem poder esperar nada da parte adversa que não a melhor estratégia para vencer, bem como a de que o juiz é um terceiro imparcial e hierarquicamente superior às partes, amarrado frente ao princípio dispositivo, aniquila qualquer possibilidade de aplicação do venire.

Mas, como constatado, tal aplicação já é uma realidade no processo. E isso com base em outras concepções da ciência processual nas quais se busca maior comprometimento dos sujeitos processuais com os escopos a serem atingidos, de forma célere e efetiva. A visão privatista vem sendo deixada de lado em prol da interpretação dos institutos processuais segundo um olhar publicista ${ }^{245}$, preocupado com a prestação de uma tutela jurisdicional de qualidade ${ }^{246}$.

A compreensão do fenômeno processual a partir de seus escopos políticos, jurídicos e, principalmente, sociais, já evidencia o caráter público do processo, destinado à resolução de conflitos de maneira tal como se o direito material jamais houvesse sido violado, objetivo que, uma vez alcançado, permite a pacificação social com justiça, permite a afirmação da autoridade do Estado, bem como a atuação da vontade concreta da $1 \mathrm{ei}^{247}$.

\footnotetext{
${ }^{244}$ JUAN MONTERO AROCA, Sobre el mito autoritario de la "buena fe procesal", p. 345.

245 "Hoje, que o direito público é conscientemente voltado à organização social e não à distribuição de bens, é mister ver no processo, ramo de direito público, alguma destinação que vá além da aspiração individual à satisfação de interesses e (agora, mais do que está naquela fórmula insuficiente) além da realização fragmentária de cada preceito jurídico concreto." (CÂNDIDO DINAMARCO, A instrumentalidade do processo, p. 199).

${ }^{246}$ Essa preocupação com a qualidade do resultado a ser atingido pelo processo não é tão recente. As palavras de JÔNATAS MILHOMENS, publicadas ainda em 1961, já demonstram a visão do processo como instrumento público, em que as partes têm limites à liberdade de atuação: "O processo é meio, pôsto a serviço do homem, para êsse fim social. O Estado, que promete a prestação jurisdicional, dá o instrumento, mas exige que se lhe dê precípua destinação. Pratiquem-se de boa-fé todos os atos processuais. Ajam as partes lealmente; colaborem todos com o órgão estatal, honestamente, sem abusos."(Da presunção da boa-fé no processo civil, p. 35).

${ }^{247}$ Sobre os escopos da jurisdição, cf. CÂNDIDO DINAMARCO, A instrumentalidade do processo, pp. 177-263.
} 
É preciso que se compreenda que o processo não é instrumento criado, pensado e a ser utilizado apenas a serviço dos interesses das partes ${ }^{248}$. A prestação da tutela jurisdicional como manifestação do poder estatal significa ser o processo um instrumento público, para a consecução também de fins estatais e com a participação, a todo o momento, de um agente do Estado, o juiz ${ }^{249}$.

Em outras palavras, o processo interessa às partes, interessa ao Estado e interessa à sociedade e é a busca da satisfação da melhor maneira possível de todos esses interesses o grande desafio do processualista contemporâneo.

Partimos da premissa de que o processo é um ramo do direito público, preocupado com resultados de qualidade, e não com a obtenção de qualquer resultado. $\mathrm{E}$ essa qualidade está em justamente se atingir a solução mais justa possível ao caso concreto, por meio de uma atuação dos sujeitos processuais também qualificada, caracterizada não pela liberdade irrestrita, mas pelo exercício de posições jurídicas processuais que se mostrem pertinentes e convergentes com os escopos do processo.

Diferentemente da concepção privatista do processo, portanto, por meio da concepção publicista é possível identificar expectativas do sistema com relação ao comportamento dos sujeitos processuais. Tais expectativas são evidenciadas pelo desenvolvimento dos conceitos de boa-fé objetiva e cooperação processual.

\subsection{A boa-fé objetiva processual}

\footnotetext{
248 “A finalidade de atuação da lei e, portanto, de alcance da verdadeira paz social, sobrepõe-se aos possíveis interesses egoístas das partes, que não são movidas pelo interesse na correta aplicação da regra material e na obtenção do resultado justo." (JosÉ RoBERTO dOS SANTOS BEDAQUE, Poderes Instrutórios do juiz, p. 71).

249 "Com efeito, a superação das concepções privatistas do processo e ascensão de sua face publicista sinalizaram no sentido de que o processo é um instrumento de que se utiliza o Estado precipuamente para finalidades públicas, e não uma ferramenta sujeita ao alvedrio das partes litigantes. Certamente que o interesse privado provoca a jurisdição, mas esta opera para manter ou restabelecer a ordem jurídica. E então se justifica a busca por retidão no manuseio dos mecanismos do processo" (ANTONIO DO PASSO CABRAL, $O$ contraditório como dever e a boa-fé processual objetiva, p. 68). JOAN PICÓ I JUNOY afirma ter sido a maior conquista do século XX para o processo a sua publicização (El derecho procesal entre el garantismo y la eficacia: Un debate mal planteado, pp. 109-110). Ainda sobre a perspectiva pública do processo: LORENA BARREIROS, Fundamentos constitucionais do princípio da cooperação processual, p. 276; MARIO MASCIOTRA, La condutcta procesal de las partes, p.14; OSVALDO GOZAÍNI, El principio de la buena fe en el proceso civil, p. 891; JôNATAS MiLhOMENS, Da presunção da boa-fé no processo civil, p. 36 e p. 42 ; ARRUDA ALVIM, Deveres das partes e dos procuradores no direito processual civil brasileiro, p. 7 , dentre muitos outros.
} 
O primeiro esclarecimento a ser feito reside no fato de ser de nosso interesse, neste momento, o estudo da boa-fé no processo em sua concepção objetiva; afinal, como vimos, é ela que funciona como critério valorativo do venire, preenchendo-lhe o conteúdo axiológico, bem como lhe conferindo a base legislativa no Direito Civil.

Mais uma vez, a tarefa de conceituar a boa-fé objetiva, porém agora sob o enfoque processual, mostra-se complexa. Afinal, também no Processo Civil ela assume a classificação de cláusula geral que contém em si um princípio - já vimos, inclusive, que a boa-fé é um princípio geral do direito ${ }^{250}$-, de modo que a vagueza e a indeterminação fazem com que a construção de uma definição prévia e estanque de boa-fé seja inadequada, além de indesejável ${ }^{251}$.

Sua imposição como princípio processual advém da constatação primeira de que ela é um princípio geral do direito aplicável às mais variadas searas jurídicas, dentre as quais o Processo Civil. Identifica-se a boa-fé como valor fundante de diferentes institutos processuais $^{252}$, alguns positivados - tais como as repressões à litigiância de má-fé em fase de conhecimento e de execução (artigos 17, 18 e 600 do CPC) -, outros observáveis quando da aplicação da norma processual, pela jurisprudência - conforme destacado no Capítulo 2 supra.

Sendo um princípio geral do direito, afirmam alguns autores que a boa-fé objetiva é um princípio processual implícito com bases constitucionais, sendo variável a conclusão entre eles quanto a qual das bases constitucionais esse princípio se apoia.

Há quem afirme ser decorrência da previsão constitucional que impõe a construção de uma sociedade livre, justa e solidária (art. $3^{\circ}$, inc. I, da Constituição Federal $)^{253}$, bem como da garantia do contraditório ${ }^{254}$. Outros sustentam que o princípio da

\footnotetext{
${ }^{250}$ A boa-fé é reconhecida como princípio geral do direito também por processualistas: LORENA BARREIROS, Fundamentos constitucionais do princípio da cooperação processual, p. 286; OsVALDO GOZAÍNI, El principio de la buena fe en el proceso civil, p. 891; DARCI GUIMARÃES RIBEIRO, O sobreprincípio da boa-fé processual como decorrência do comportamento da parte em juízo, p. 77; MARIANA PRETEL E PRETEL, $A$ boa-fé objetiva e a lealdade no processo civil brasileiro, p. 166.

251 "Podemos decir que la buena fe alude muy en general a un comportamiento correcto. La dificultad es que el concepto de lo correcto es tan genérico como el de buena fe por lo que definirla así resulta casi una tautología. Caulquier otra definición a priori que se intente, puede caer en la misma cuestión. Sin embargo, no se puede desconocer que cuando se alude a lo correcto, dentro del proceso, al menos en la tradición de cultura de los operadores jurídicos, existe una significación que dice relación con el comportamiento leal. Atendida la generalidad del término, nociones más precisas, sólo pueden lograrse a través de la creación de patrones por la vía inductiva jurisprudencial o legislativa" (FRANCESCO CARRETTA MuÑOZ, Deberes procesales de las partes en el proceso civil chileno, p. 117).

${ }^{252}$ JOAN PICÓ I JUNOY, El principio de la buena fe procesal, p. 51.

${ }^{253}$ BRUNELA VIEIRA DE VINCEZI, A boa-fé no processo civil, p. 163.

${ }^{254}$ BRUNELA VIEIRA DE VINCEZI, A boa-fé no processo civil, p. 172.
} 
boa-fé processual pode ser extraído de muitos outros princípios constitucionais, não só da solidariedade e do contraditório, mas também da dignidade da pessoa humana e do devido processo legal $^{255}$.

A perspectiva pela qual o mesmo problema foi analisado por PICó I JUNOY, todavia, parece-nos mais interessante, até porque juridicamente mais consistente, já que fundada em uma única concepção da relação entre a boa-fé e as garantias constitucionais. Para o autor espanhol, o fundamento constitucional da boa-fé é depreendido da realidade de que nenhum direito fundamental pode ser exercido de maneira irrestrita e abusiva, posicionando-se a boa-fé objetiva como um limite a esse exercício, mas jamais um limite à existência do direito em $\mathrm{si}^{256}$.

Até porque, o convívio de diferentes direitos fundamentais processuais - tais como aqueles apontados pelos demais autores como base constitucional da boa-fé processual - nem sempre se dá de maneira harmônica, fazendo-se necessário balancear a aplicabilidade simultânea deles frente a um caso concreto. Dessa forma, o limite do exercício de um direito fundamental se justifica na medida em que privilegie a observância de outro valor igualmente relevante ao processo.

E, para Picó I JunOY, é impossível delimitar a priori todos os direitos a serem protegidos, mas, de maneira geral, utiliza-se a boa-fé como fundamento justificador do limite do exercício de posições jurídicas processuais de modo a viabilizar a plena observância de direitos fundamentais como o da efetividade da tutela jurisdicional, da defesa, da igualdade processual e o do processo sem atrasos indevidos ${ }^{257}$.

\footnotetext{
${ }^{255}$ Fredie Didier JR., Fundamentos do Princípio da Cooperação no Direito Processual Civil Português, pp. 86-89. LORENA BARREIROS compartilha desse mesmo entendimento (Fundamentos constitucionais do princípio da cooperação processual, p. 285).

${ }^{256}$ Nas palavras do autor: "En mi opinión, esta discusión sobre el rango formal de las normas en conflicto, debe superarse por el hecho de que no estamos propriamente ante límites a los derechos sino ante reglas para su válido ejercicio (....). En consecuencia, cuando un texto normativo - como la Constituición y su art. 24 recoje derechos subjetivos, lo que pretende es garantizar su plena vigencia siempre que se ejerciten válidamente, esto es, no exista un ejercicio abusivo o antisocial del mismo. De esta forma, la mala fe actua no como limite al contenido del derecho sino a su ejercicio, esto es, a la manera en que pretende llevarse a cabo en un caso concreto, debiéndose en todo caso motivar judicialmente su existencia en la medida en que se restringe el ejercicio de un derecho fundamental" (JOAN PICÓ I JUNOY, El principio de la buena fe procesal, pp. 82-84).

${ }^{257}$ Para que se depreenda de maneira fiel as ideias do autor, mas uma vez, na íntegra, destacam-se suas palavras: "Dado que la mala fe puede materializarse en una infinidad de actos procesales que responden a fines concretos, es imposible reducir a uno sólo los derechos fundamentales que pueden protegerse acudiendo al criterio o fundamento justificador de la buena fe procesal, si bien, por regla general, éstos serán los derechos fundamentales a la tutela judicial efectiva, a la defensa, a la igualdad procesal y a un proceso sin dilaciones indebidas" (JOAN PICÓ I JUNOY, El principio de la buena fe procesal, p. 87).
} 
A boa-fé objetiva funciona, portanto, como critério otimizador da compatibilização das garantias fundamentais, que permite, por exemplo, restringir o direito de defesa, quando exercido de maneira abusiva, de modo a apenas retardar o curso do processo, ou que viabiliza a fungibilidade recursal mitigando-se a estrita legalidade, em observância da boa-fé fundada na dúvida objetiva dos possíveis caminhos existentes para manifestação da insurgência, privilegiando-se a ampla defesa ${ }^{258}$.

O fato é que, apesar de bastante enriquecedor o debate quanto às bases constitucionais da boa-fé - até porque essa conclusão reafirma suas bases de princípio geral de direito e, portanto, aplicável aos mais diversos microssistemas jurídicos -, para nós, é suficiente a constatação da existência da boa-fé objetiva como cláusula geral no Código de Processo Civil, o que já nos permite falar em boa-fé e processo.

A existência da cláusula geral está estampada no artigo 14, inciso II do nosso atual Código de Processo Civil, ao afirmar como dever das partes e de todos aqueles que de qualquer forma participem do processo o proceder com lealdade e boa-fé. Note-se a vagueza conceitual e o reenvio a valores, o que, paralelamente à constatação expressa no ordenamento, permite identificar a natureza de cláusula geral do referido artigo ${ }^{259}$.

E a existência de uma cláusula geral impondo o dever de se comportar no processo conforme a boa-fé não é exclusividade do ordenamento brasileiro ${ }^{260}$. A Ley de

\footnotetext{
${ }^{258}$ Sobre a função otimizadora das garantias processuais da boa-fé, cf. LEIDE SANTOS, Boa-fé objetiva no processo civil, pp. 39 e seguintes. A autora afirma que "diante de tamanha relevância do princípio do devido processo legal e das demais garantias constitucionais processuais dele decorrentes, expressas, sobretudo, na ampla defesa e no contraditório, desponta a boa-fé objetiva como norma otimizadora dessas garantias constitucionais. Esses direitos ou garantias constitucionais processuais não são irrestritos, não podem ser utilizados como armaduras para legitimar condutas que afrontem a boa-fé objetiva dos sujeitos processuais" (LEIDE SANTOS, Boa-fé objetiva no processo civil, p. 44). É o que sustenta DARCI GUIMARÃES RIBEIRO ao afirmar o caráter de sobreprincípio da boa-fé processual, "posto que paira por cima dos demais princípios jurídicos, conseqüentemente condiciona, determinado no espaço e no tempo, sua interpretação" ( $O$ sobreprincípio da boa-fé processual como decorrência do comportamento da parte em juízo, p. 78).

259 “'O inc. II do art. 14 do CPC é uma cláusula geral processual: espécie normativa composta por termos de acepção vaga (aberta, portanto, no antecedente normativo) e que também é indefinida em relação às consequências derivadas de sua desobediência (aberta, pois, também, na prescrição normativa). A opção por uma cláusula geral de boa-fé processual é a mais correta. É que a infinidade de situações que podem surgir ao longo do processo torna pouco eficaz qualquer enumeração legal exaustiva das hipóteses de comportamento desleal." (FREDIE DIDIER JR., Multa coercitiva, boa-fé processual e supressio: aplicação do duty to mitigate the loss no processo civil, pp. 38-39). No mesmo sentido: ANTONIO DO PASSO CABRAL, $O$ contraditório como dever e a boa-fé processual objetiva, p. 77; ANDRESSA PAULA SENNA, O abuso de direito e a litigância de má-fé como impeditivos à marcha processual e ao resultado justo da prestação jurisdicional, p. 17 e 25 ; Humberto TheOdORO JÚNIOR, Boa-fé e processo, p. 645-646; FredIE DIDIER JR., Fundamentos do Princípio da Cooperação no Direito Processual Civil Português, p. 90; ARRUdA AlviM, Deveres das partes $e$ dos procuradores no direito processual civil brasileiro, p. 9; José MARCELO BARRETO PIMENTA, $O$ princípio da boa-fé processual e a ineficácia prática da multa por litigância de má-fé, p. 468.

${ }^{260}$ Em verdade, segundo MICHELE TARUFFO, a menção à boa-fé é generalizada: "Em primeiro lugar, há de ser notado que algumas cláusulas gerais ou princípios gerais concernentes ao abuso de instrumentos
} 
Enjuiciamiento Civil Espanhola, em seu artigo 247, possui dispositivo bastante semelhante ao nosso, afirmando que os intervenientes em todo tipo de processo devem observar em suas atuações as regras da boa-fée ${ }^{261}$. O Código Procesal Civil y Comercial de La Nación, na Argentina, prevê como dever do juiz a condução do procedimento de modo a prevenir e sancionar todo o ato contrário ao dever de lealdade, probidade e boa-fé (art. 34, 5, IV).

No Uruguai, o Código General del Proceso, logo na parte inicial dos princípios gerais, prevê no artigo quinto o princípio da boa-fé e lealdade processual, descrevendo que as partes, seus representantes ou assistentes e, em geral, todos os participantes do processo, ajustarão suas condutas conforme a dignidade da Justiça, o respeito que devem os litigantes e de acordo com a lealdade e a boa-fé ${ }^{262}$.

Em Portugal, o artigo $266^{\circ}$-A do Código de Processo Civil introduz o dever de boa-fé processual, afirmando que "as partes devem agir de boa fé e observar os deveres de cooperação resultantes do preceituado no artigo anterior", o qual, por sua vez, prevê o princípio da cooperação, como veremos no item seguinte.

Isso sem mencionar outros ordenamentos que, apesar de não utilizarem a expressão "boa-fé", fazem referência a ideias semelhantes. É o caso, por exemplo, do Codice de Procedura Civile Italiano, que, no campo dos deveres das partes e dos seus procuradores, afirma no artigo 88 , o dever de comportarem-se com lealdade e probidade ${ }^{263}$.

Em que consiste, portanto, tantas referências à boa-fé processual?

$\mathrm{Na}$ tentativa de delinear seus principais contornos, PICÓ I JUNOY afirma ser a boa-fé processual aquela conduta exigível a todas as pessoas no processo, por ser

processuais são utilizados quase em todos os lugares. A cláusula geral mais comum que é referida nos sistemas e civil law é a 'cláusula de boa-fé' sob seus vários nomes: bona fides, buona fede, Treu und Glaube, e assim por diante" (Abuso de direitos processuais, pp. 156-157). Sobre as referências à boa-fé processual em diversos ordenamentos, $c f$. JOAN PICÓ I JUNOY, El principio de la buena fe procesal, pp. 142-145; DARCI GUIMARÃES RIBEIRO, O sobreprincípio da boa-fé processual como decorrência do comportamento da parte em juízo, pp. 73-76; LEIDE SANTOS, A boa-fé objetiva no processo civil, pp. 194-200.

${ }^{261}$ No original: "Los intervinientes en todo tipo de procesos deberán ajustarse en sus actuaciones a las reglas de la buena fe".

262 "Buena Fe y lealtad procesal - Las partes, sus representantes o asistentes y, en general, todos los participes del proceso, ajustarán su conducta a la dignidad de la Justicia, al respecto que se deben los litigantes y a la lealtad y buena fe. El tribunal deberá impedir el fraude procesal, la colusión y cualquier otra conducta ilícita o dilatoria."

${ }^{263}$ Ipsis litteris: "Le parti e i loro difensori hanno il dovere di comportarsi in giudizio con lealtà e probità. In caso di mancanza dei difensori a tale dovere, il giudice deve riferirne alle autorità che esercitano il potere disciplinare su di essi." 
socialmente admitida como correta ${ }^{264}$. Por meio dela, as interações sociais tornam-se mais estáveis, admitindo-se a proteção das expectativas que delas emanam ${ }^{265}$.

É um dos mecanismos mais eficazes para introduzir um conteúdo ético-moral no sistema processual, permitindo aos operadores do direito a adequação da aplicação da técnica conforme os valores sociais de cada momento histórico.

Vê-se que a vagueza do conceito é vista como a principal vantagem da referência legislativa à boa-fé processual, permitindo-se a maleabilidade da interpretação conforme as peculiaridades de cada caso concreto, bem como considerando cada contexto sociocultural em que se insere.

Isso porque, verificado o fenômeno da insuficiência legislativa para previamente tratar de todos os possíveis conflitos de direito material, não é menos verdade que o legislador processual é também incapaz de regular todos os tipos de procedimentos $a$ priori, e conquistar a efetividade dos institutos por meio de uma previsão tipificada de cada possível instrumento à disposição dos litigantes. Justamente por esse motivo observa-se o aumento da importância do princípio da adaptabilidade procedimental ${ }^{266}$, bem como o incremento dos poderes do juiz, para que, por meio de uma maior liberdade de sua atuação, ele funcione como um veículo de otimização da utilização das normas processuais, a fim de se alcançar a máxima efetividade do processo $^{267}$.

Nesse contexto, pode-se imaginar a dificuldade que teria o legislador ao tentar vislumbrar previamente todas as possíveis hipóteses de comportamentos processuais contrários à boa-fé. Qualquer tentativa de rol taxativo seria insuficiente para esgotar a criatividade das partes e seus procuradores em tentar driblar um resultado desfavorável no

\footnotetext{
264 "La buena fe es un concepto jurídico indeterminado, y por lo tanto sólo pueden efectuarse meras aproximaciones conceptuales sobre la misma. Desde esta perspectiva ncesariamente genérica, la buena fe procesal la he definido como aquella conducta exigible a toda persona, en el marco de un proceso, por ser socialmente admitida como correcta" (JOAN PICÓ I JUNOY, El principio de la buena fe procesal, p. 72).

${ }^{265}$ ANTONIO DO PASSO CABRAL, Nulidades do processo moderno, p. 241.

266 JosÉ ROBERTO DOS SANTOS BEDAQUE, Efetividade do processo e técnica processual, pp. 109-112.

${ }^{267}$ Sobre o tema, LUIZ MARINONI afirma que "Também o direito processual civil foi repentinamente marcado por um paulatino e progressivo aumento dos poderes do juiz. Deixou-se de lado a rigidez das regras e a suposição de que a segurança e a igualdade apenas poderiam ser garantidas caso o juiz não tivesse espaço para fugir da letra da lei e da tipicidade das formas processuais. Foram instituídas no Código de Processo Civil normas com conceitos vagos e outras que expressamente atribuem ao juiz o poder-dever de adotar a técnica processual necessária à adequada tutela de direito material no caso concreto. A alteração do direito processual civil e da função judicial no aspecto procedimental têm relação com a necessidade de se dar ao juiz poder e mobilidade que lhe permitam tutelar de forma efetiva as novas situações de direito substancial" (O precedente na dimensão da igualdade, pp. 283-239). No mesmo sentido, $c f$. LEIDE SANTOS, Boa-fé objetiva no processo civil, p. 29.
} 
processo, sendo de fundamental importância a existência de uma cláusula aberta de repressão a condutas inadmissíveis ${ }^{268}$.

Acresce-se a isso o fato de que uma mesma conduta, dependendo do contexto processual em que se insere, pode ou não caracterizar violação à boa-fé. Como exemplo, pode-se citar a renúncia da parte à produção de uma prova por ela já pleiteada e já deferida pelo juízo. Pode ser que, no contexto daquele processo, a renúncia tenha como fundamento a inutilidade superveniente da produção da prova, pois o fato que por meio dela se pretendia demonstrar acabou sendo comprovado por um documento trazido pela parte contrária. Assim, tal renúncia não só deixa de violar a boa-fé como a privilegia, tendo a parte buscado apenas otimizar o trâmite processual.

Por outro lado, essa mesma renúncia pode significar afronta à boa-fé se não houver justificativa para a desistência, desconfiando-se de que a parte só renunciou à prova pela constatação de que ela the poderia ser desfavorável. Entretanto, uma vez requerida a prova e deferida pelo juízo, cria-se na parte contrária e no magistrado a legítima confiança de que ela seria produzida, e, sem qualquer motivo para a não realização, a renúncia acaba por representar um ato contraditório e violador da boa-fé objetiva ${ }^{269}$.

Pelo exemplo dado é possível perceber o quanto se faz necessário que o conteúdo da boa-fé seja preenchido somente frente ao caso concreto, diante da relatividade que ele possui quando confrontado com diferentes contextos processuais.

Verificadas, pois, as vantagens de uma definição aberta do conceito de boa-fé objetiva no processo, ela deve ser vista como um parâmetro processual de conduta, um critério a partir do qual se interpreta um comportamento como desejável ou indesejável ao processo, critério capaz de criar deveres processuais anexos, além de limitar o exercício de posições jurídicas processuais que se desviem dos escopos do processo ${ }^{270}$. O conteúdo dessa regra de conduta deve se fundar na honestidade, na lealdade, na cooperação para que se chegue ao melhor resultado possível no processo $^{271}$.

\footnotetext{
${ }^{268}$ Fredie Didier JR., Fundamentos do Princípio da Cooperação no Direito Processual Civil Português, pp. $80-81$.

${ }^{269} \mathrm{O}$ exemplo da renúncia de prova já requerida e deferida, como possível hipótese de venire a depender do contexto, é de JOAN PICó I JUNOY, El principio de la buena fe procesal, p. 179.

270 "Num segundo momento, a regra da boa-fé assume a função de fonte criadora de deveres de cooperação e colaboração, e é regra limitadora do exercício inadmissível de posições jurídicas na relação jurídica processual que tem lugar perante o órgão jurisdicional estatal." (BRUNELA VIEIRA DE VINCEZI, A boa-fé no processo civil, p. 24).

${ }_{271}$ BRUNELA VIEIRA DE VINCEZI, A boa-fé no processo civil, p. 159.
} 
Não se pode negar, porém, que o conceito de boa-fé jamais será puramente jurídico $^{272}$. O preenchimento de seu conteúdo sempre levará em conta valores sociais ${ }^{273}$, ou seja, parâmetros morais comuns à sociedade para afirmar o que é ou deixa de ser contrário à boa-fé. No que diz respeito ao processo, certamente a utilização do conceito de boa-fé permite se fazer sentir a comunicação entre processo e valores, que há muito deixaram de ser ideias opostas ${ }^{274}$.

E, pela afirmação de ser a boa-fé um parâmetro de conduta, busca-se evidenciar que a análise de um comportamento processual como condizente ou não com os parâmetros sociais de boa-fé prescinde da averiguação do íntimo do agente, da intencionalidade ou não de prejudicar o bom andamento do processo. A conduta é analisada sob sua perspectiva exteriorizada, bastando a aparência da ruptura da boa-fé para que seja considerada indesejável ao processo $^{275}$.

Os comportamentos processuais devem ser presumidamente encarados como convergentes com a boa-fé. Pelo paralelo construído por RUI STOCO, assim como o homem nasce naturalmente bom, sendo a má-fé o que evidencia o desvio da personalidade ${ }^{276}$,

272 "La buena fe, como las buenas costumbres, comunica el derecho con la moral." (OsVALDO GOZAínI, La conducta en el proceso, p. 15). Assim afirmam também RUI STOCO, Abuso do direito e má-fé processual, $\mathrm{p}$. 38; LEIDE SANTOS, Boa-fé objetiva no processo civil, p. 25.

${ }^{273}$ JOAN PICÓ I JUNOY, El principio de la buena fe procesal, p. 70.

274 "A ideia tradicional de que não há moralidade processual e que qualquer conduta é boa, desde que apenas se respeite sua forma legal, não é mais confiável. Padrões de moralidade processual, justiça, lealdade, boa-fé, devido processo, correção, etc. tornam-se mais e mais penetrantes e relevantes mesmo em países onde eles não tinham real significância até recentemente." (MICHELE TARUFFO, Abuso de direitos processuais, p. 181). E ainda: "Nessa concepção axiológica de processo, como instrumento de garantia de direitos, a visão puramente técnica não pode mais prevalecer, pois a ela se sobrepõe valores éticos de liberdade e de justiça. (...) A regulamentação do processo depende basicamente de concepções filosóficas, políticas e culturais inerentes ao direito material. Daí ser insuficiente o formalismo dogmático, que deve ser complementado pela idéia de valor." (José Roberto DOS SANTOS Bedaque, Direito e Processo, pp. 20-24). Ainda sobre a relação entre processo e valores, $c f$. CARLos Alberto Alvaro De OliveIra, Do formalismo no processo civil, pp. 92-98; LORENA BARREIROS, Fundamentos constitucionais do princípio da cooperação processual, p. 229.

275 Antonio do Passo CABral, Nulidades do processo moderno, p. 241; Fredie Didier JR., Multa coercitiva, boa-fé processual e suppressio: aplicação do duty to mitigante the loss no processo civil, pp. 3738; ALDEMIRO REZENDE DANTAS JÚNIOR, Teoria dos atos próprios no princípio da boa fé, p. 138; LORENA BARREIROS, Fundamentos constitucionais do princípio da cooperação processual, p. 302; BRUNELA VIEIRA DE VINCEZI, A boa-fé no processo civil, p. 165; FREDIE DIDIER JR., Fundamentos do Princípio da Cooperação no Direito Processual Civil Português, p. 91; Osvaldo GoZAÍnI, El principio de la buena fe en el proceso civil, p. 893; GUSTAVo PRAZERES, Venire contra factum proprium nulli conceditur e direito material, p. 153; Ana Paula ChIovitTi, A boa-fé no Processo Civil e os mecanismos de repressão do dolo processual, p. 26. O entendimento, todavia, não é uníssono na doutrina, pois há que entenda que o art. 14, inc. II, do CPC se refere à boa-fé subjetiva. Nesse sentido $c f$. FABIO MILMAN, Improbidade processual: comportamento das partes e de seus procuradores no processo civil, p. 101.

${ }^{276}$ Abuso do direito e má-fé processual, p. 37. No mesmo sentido: "Parece, pois, que a boa-fé é uma qualidade intrínseca do ser humano, sendo a má-fé, portanto, o resultado de um caminho anormal escolhido pelo caráter individual de uma pessoa" (DARCI GUIMARÃES RIBEIRO, O sobreprincípio da boa-fé processual 
também no processo deve-se ter como ponto de partida que os sujeitos processuais atuam de boa-fé, fazendo-se necessário demonstrar por elementos de convicção realidade em sentido contrário, capaz de romper essa presunção ${ }^{277}$.

Não se deve, portanto, opor qualquer tipo de limitação antes de configurado um comportamento contrário à boa-fé ${ }^{278}$, sob pena de se mitigar, sem qualquer razão, o direito à liberdade processual. A liberdade permanece até que sejam identificadas condutas contrárias à boa-fé, ou seja, até que haja uma real necessidade de se mitigar a liberdade de atuação, em prol da proteção de outros valores, como o da efetividade do processo.

Essa presunção incide sobre todos os sujeitos do processo, pois a boa-fé objetiva, nos termos expostos pelo próprio artigo 14, inc. II, do Código de Processo Civil, é regra de conduta a ser observada por todos aqueles que de alguma forma participem do processo, ou seja, aplicável não só às partes, mas também aos procuradores e ao órgão jurisdicional $^{279}$. Essa ideia ficará ainda mais evidente quando complementada pelos postulados do processo cooperativo, o que veremos adiante.

O descumprimento da boa-fé pode ser alegado por qualquer uma das partes atuantes no processo, bem como pode ser reconhecida de ofício pelo juiz ${ }^{280}$, que então aplicará os efeitos da inobservância da boa-fé independentemente de requerimento das partes. Afinal, partindo-se das premissas supra delineadas de que o processo é instrumento público, a figura do juiz traz a peculiaridade, com relação aos estudos desenvolvidos no âmbito do Direito Civil, de que não só perante as partes pode haver afronta à boa-fé, mas também diante dos interesses do próprio Estado.

Assim é que, no Processo Civil, a constatação da ruptura da boa-fé pouco depende da indicação de um dano, já que o Estado é sempre lesado pela inobservância, pelas partes, de seus deveres de comportamento ${ }^{281}$. Com base nessa premissa, é fácil compreender a atuação de ofício do magistrado: tão logo constatado o desvio de conduta

como decorrência do comportamento da parte em juízo, p. 72) e ainda LEONARDo GRECO, Publicismo e privatismo no processo civil, p. 49.

${ }^{277}$ No mesmo sentido, porém no contexto das invalidades e a boa-fé, é o que afirma ANTONIO DO PASSO CABRAL, Nulidades no processo moderno, p. 243.

${ }^{278}$ JÔNATAS Milhomens, Da presunção da boa-fé no processo civil, p. 51.

${ }^{279}$ Fredie Didier JR., Fundamentos do Princípio da Cooperação no Direito Processual Civil Português, p. 80. Isso sem falar nos demais sujeitos do processo, como os auxiliares da justiça, que também se submetem à boa-fé.

${ }^{280}$ JOAN PICÓ I JUNOY, El principio de la buena fe procesal, pp. 135-137.

${ }^{281}$ FABIO MILMAN, Improbidade processual, p. 101. Assim afirma também LEIDE SANTOS, Boa-fé objetiva no processo civil, p. 143; JOSÉ MOACYR DORETTO NASCIMENTO, A boa-fé objetiva e o processo civil, p. 71; Ana Paula ChiovitTi, A boa-fé no Processo Civil e os mecanismos de repressão do dolo processual, p. 32. 
de qualquer sujeito processual, os escopos do processo são prejudicados, o que justifica a intervenção judicial.

Segundo a doutrina especializada no tema - que, frise-se, é bastante reduzida -, as consequências da afronta à boa-fé processual são as mais vastas possíveis. Isso porque, se o instituto tem por finalidade afastar comportamentos que fogem ao padrão de conduta desejado, e esses podem ser os mais diversos, é certo que uma única consequência sancionadora se revelaria insuficiente ${ }^{282}$. Some-se a isso o fato de que, por ser uma cláusula geral, suas consequências normativas não precisam ser típicas ${ }^{283}$.

Pontuam-se de maneira genérica as modalidades identificadas, para que uma discussão mais aprofundada sobre o tema seja feita quando da análise das consequências da aplicação do venire no processo ${ }^{284}$.

O primeiro efeito identificado é a ineficácia do ato: o exercício de posição jurídica processual contrária à boa-fé pode significar sua inadmissibilidade e, consequentemente, sua impossibilidade de produzir efeitos ${ }^{285}$. Ou, ainda, há a consequência de pura ineficácia, já que um ato processual exercido infringindo a boa-fé não pode imprimir a eficácia pretendida ${ }^{286}$. Além disso, é possível valorar a conduta da parte, que funciona como um elemento de convicção, um indício a partir do qual podem ser geradas presunções, tema que será enfrentado no item 6.3 infra ${ }^{287}$.

\footnotetext{
282 "El reconocimiento del principio de la buena fe quedaria en una mera proclamación programática si la Ley no previera mecanismos de protección tendentes a potenciar su virtualidad práctica. Por ello, la infracción de las reglas que se han analizado puede originar consecuencias de muy distinto alcance, que varían en función de la configuración de la concreta regla como una carga, una obligación o un deber procesal. Atendiendo al contenido de tales consecuencias, se pueden clasificar en procesales y extraprocesales: en el primer grupo, nos encontramos con la inadmisión del acto procesal solicitado, la ineficacia del acto procesal realizado, la pérdida de las cantidades económicas depositadas judicialmente para la realización de actos procesales, la valoración intraprocesal de la conduta de las partes, las multas, las costas procesales, la nulidad de actuaciones, la pérdida del pleito, o el uso de la coacción física para contrarrestar la mala fe procesal. Y, en el segundo, analizaré el problema de la responsabilidad disciplinaria, civil y penal, en la que puede incurrir el abogado que actúe con mala fe procesal" (JOAN PICÓ I JUNOY, El principio de la buena fe procesal, p. 309).

${ }^{283}$ FREDIE DIDIER JR., Cláusulas gerais processuais, p. 280.

${ }^{284}$ Como veremos, nossos estudos indicam que o venire processual é uma modalidade de abuso de processo, pela ruptura da boa-fé, ou seja, está contido no conceito de abuso de direito, que, por sua vez, configura-se também quando inobservado o valor boa-fé no processo. Assim, identificar todas as consequências da ruptura da boa-fé, para posteriormente analisar todas as consequências do abuso do processo, até que finalmente se chegue à discussão sobre os possíveis efeitos do venire processual seria repetitivo, monótono e sem grande utilidade. Guardaremos a abordagem aprofundada sobre o tema para o Capítulo 8 infra.

${ }_{285}^{25}$ JOAN PICÓ I JUNOY, El principio de la buena fe procesal, p. 310; OSVALDO GOZAÍNI, La conducta en el proceso, p. 32; BRUNELA VINCENZI, A boa-fé no processo civil, p. 172.

${ }^{286}$ JOAN PICÓ I JUNOY, El principio de la buena fe procesal, p. 311.

${ }^{287}$ Sobre a valoração da conduta da parte como consequência da ruptura da boa-fé, $c f$. JOAN PICÓ I JUNOY, $E l$ principio de la buena fe procesal, pp. 313-317.
} 
Outra possível consequência é a conservação do ato que, por meio de violação à boa-fé, pretendeu-se anular, como ocorre com muitas das hipóteses de alegação tardia da existência de uma nulidade no processo $^{288}$.

E, por fim, tem-se todas as hipóteses que envolvem sanções pecuniárias, tais como multas, aumento ou inversão dos ônus de sucumbência e indenização por perdas e danos eventualmente configurados em razão do comportamento processual contrário à boa-fé.

\subsubsection{Críticas à boa-fé(?)}

Há uma corrente doutrinária que não aceita a existência do princípio da boa-fé objetiva incidente no processo, principalmente pela discordância com a premissa por nós adotada, qual seja, a de que o processo é um instrumento público, de que decorrem muitas outras consequências, tais como o papel ativo do juiz na condução do processo e a própria incidência da boa-fé ${ }^{289}$.

Sustenta-se, por exemplo, que a inserção da boa-fé como parâmetro de conduta processual foi feita por leis promulgadas em regimes autoritários, que têm por base a premissa de um juiz superior e perfeito, responsável por alcançar a justiça- o que inexiste no mundo real -, ao passo que as partes são tratadas somente com a imposição de deveres, como se fossem menores de idade a serem tuteladas ${ }^{290}$.

Afirma-se ser autoritário o conteúdo da boa-fé se ela significar o abandono, pelo advogado, da função de proteger os interesses de seu cliente, para assumir a função pública de colaborar com o juiz na busca da justiça ${ }^{291}$.

\footnotetext{
${ }^{288}$ OSVALDO GOZAÍNI, La conducta en el proceso, p. 34.

289 Entre os principais críticos, destaca-se CIPRIANI e MontAlEONE, na Itália, Montero ArocA, na Espanha, e AlVARAdo VELloso na Argentina, conforme os apontamentos de JOAN Picó I JUNOY, El derecho procesal entre el garantismo y la eficacia: Un debate mal planteado, pp. 112-116. O aprofundamento nas ideias desses autores faria com que desviássemos de nosso tema, já que as principais críticas são feitas ao aumento do poder do juiz, e não à boa-fé propriamente dita.

${ }^{290}$ JUAN MONTERO AROCA, El proceso civil llamado "social”" como instrumento de "justicia” autoritária, p. 161.

${ }^{291}$ JUAN MONTERO AROCA, El proceso civil llamado "social” como instrumento de "justicia” autoritária, p. 162.
} 
Destaca-se, ainda, que o conceito de boa-fé surge em uma ideologia política comunista, que fixa como escopo do processo o alcance da verdade objetiva, impondo às partes o dever de colaborar com o juiz para que se atinja essa finalidade ${ }^{292}$.

Entretanto, divergimos não só das premissas de que partem tais críticas, mas também do que se compreendeu pelo conceito de boa-fé. E, ao final, demonstraremos que, apesar de ideologias totalmente diversas sobre o processo, no que diz respeito à boa-fé processual é possível alcançar um ponto comum interpretativo.

Em primeiro lugar, o fato de uma lei ter sido promulgada no curso de um regime autoritário não faz dela, em si, autoritária. Isso foi demonstrado por BARBOSA MOREIRA, que, por meio de uma análise detalhada de regimes legislativos processuais originados de governos políticos autoritários, concluiu por inexistir essa necessária correspondência, principalmente com relação à tendência de regimes autoritários fortalecerem os poderes do juiz, o que concluiu por ser uma inverdade ${ }^{293}$. Como exemplo, inclusive, vê-se que a boa-fé processual esteve prevista em regimes anteriores àqueles autoritários, bem como inserida como cláusula geral em leis promulgadas já em regimes democráticos, como é o caso do art. 247 da Ley de Enjuiciamento Civil ${ }^{294}$.

Ademais, como bem apontado por PICó I JunOY, mais do que a "bondade da lei”, é crucial para que ela seja classificada como não autoritária a forma com que é aplicada na prática forense, sendo talvez mais relevante a ideologia do aplicador do direito do que a do legislador que a formulou ${ }^{295}$.

Uma vez que a boa-fé é exigível de todos aqueles atuantes no processo, inclusive do juiz, não nos parece que ela coloca o magistrado em posição superior à das partes, e nem impõe excessivos deveres a elas em contraposição à concessão de poderes excessivos ao juiz. É certo que será o juiz, ao final, quem dirá se houve ou não afronta à

\footnotetext{
292 JUAN MONTERO AROCA, Sobre el mito autoritario de la “buena fe procesal”, p. 337.

293 O neoprivatismo no processo civil, pp. 90-92. LEONARDO GRECO afirma, ainda, que a promulgação de leis autoritárias é inversamente proporcional à capacidade de promover o autoritarismo sem o apoio legal (Publicismo e privatismo no proceso civil, p. 37). Sobre o tema, cf. MiCHELE TARUFFO, Poteri probatorio delle parti e del giudice in Europa, pp. 242-254.

294 JOAN PICÓ I JUNOY, El derecho procesal entre el garantismo y la eficacia: Un debate mal planteado, pp. 117-119.

${ }^{295}$ El derecho procesal entre el garantismo y la eficacia: Un debate mal planteado, p. 117. Assim, com razão BARBOSA MOREIRA ao afirmar que "constitui exagero de simplificação conceber essa relação à guisa de vínculo rígido, automático e inflexível, para considerar que, se determinada lei (processual ou qualquer outra) surgiu sob governo autoritário, essa contingência cronológica fatalmente lhe imprime o mesmo caráter e a torna incompatível com o respeito às garantias democráticas. A realidade é sempre algo mais complexa do que a imagem que dela propõem interpretações assim lineares, para não dizer simplórias." ( $O$ neoprivatismo no processo civil, pp. 88-89).
} 
boa-fé - isso com o auxílio do duplo grau de jurisdição, com papel ainda mais fundamental para o reconhecimento de rompimento de boa-fé nos casos em que ele houver sido praticado pelo próprio magistrado -, mas é exatamente essa a sua função, a de emitir juízos decisórios acerca dos fatos que se mostrem controvertidos no curso do processo. Se houver receio de que ele diga sobre a boa-fé, receio maior deve se ter sobre o próprio julgamento do objeto do processo e, se assim fosse, o método de trabalho que chamamos de processo precisaria ser reestruturado como um todo ${ }^{296}$.

A fobia de autoritarismos teria uma maior relevância se inserida em um sistema processual ainda pouco desenvolvido, carente de garantias às partes para que elas tenham assegurados mecanismos de participação e de defesa efetivos, de instrumentos suficientes para manifestarem suas insurgências e suas concordâncias. Mas o estágio evolutivo atual do processo nos apresenta garantias já consolidadas, constitucionalmente previstas e compreendidas pelos sujeitos processuais que, se as ignoram vez ou outra, submetem-se aos mecanismos de correção do ato processual, tais como o reconhecimento de nulidades e a substituição de atos decisórios por outros de grau de jurisdição diverso.

Disso se conclui que fazer as condutas processuais se pautarem na boa-fé não significa aceitar autoritarismos no processo, já que esse parâmetro de conduta conviverá com o princípio do devido processo legal, do contraditório e da ampla defesa, da motivação das decisões judiciais, entre tantos outros que impedirão excessos.

Admitamos, porém, que apesar das vantagens já descritas decorrentes de a boafé ser um conceito dotado de vagueza, seja possível que se observem abusos quando de sua aplicação. Em tese, a ausência de delimitação de seus significados a priori pode fazer com que ela seja aplicada descriteriosamente, prejudicando o livre exercício de manifestação

\footnotetext{
${ }^{296}$ A força argumentativa do trecho justifica sua reprodução integral: "Finalmente, debe destacarse que si bien es cierto que la indeterminación del contenido de la buena fe puede plantear el problema de la inseguridad jurídica, ya que puede utilizarse por el juez como medio para imponer sus propias valoraciones personales al margen de las comúnmente aceptadas por la sociedade, favoreciendo de este modo la aparición de la arbitrariedad, este peligro puede superarse, en primer lugar, mediante la exigencia de la motivación de la resolución en la que se aprecie la mala fe de un litigante - y el posterior control a través de los recursos procedentes contra dicha resolución - y, en segundo lugar, como se ha indicado anteriormente, mediante la creación de una doctrina jurisprudencial que identifique supuestos típicos de mala fe que, em principio, serán susceptibles de aplicarse con carácter general a situaciones equivalentes, si bien ello sólo podrá tener lugar una vez analizadas las particularidades de cada proceso. Pero, en cualquier caso, hemos de ser conscientes de que nunca será posible soslayar el problema de la inseguridad jurídica propia de toda decisión judicial, pues en su formación intervienen, junto a los juicios históricos y lógicos sobre los hechos enjuiciados y las normas aplicables, juicios de valor, subjetivos, que surgen de la propia formación y cultura del juez, y que para el caso concreto son los que llevan a interpretar las normas de una determinada forma. En definitiva, si bien es cierto que este subjetivismo se incrementa cuando nos encontramos ante conceptos jurídicos indeterminados, no es menos cierto que, en mayor o menor intensidad, este elemento subjetivo es implícito a todo juicio jurisdiccional" (JOAN PICÓ I JUNOY, El principio de la buena fe procesal, pp. 75-76).
} 
das partes. Afinal, não se pode olvidar que, conforme alerta FRANCO CIPRIANI, se as partes estão em posições contrapostas, não necessariamente siginifica que uma delas esteja mentindo, mas apenas que vêem o mundo a partir de pontos de vista distintos, sendo o mundo do direito o mundo da dúvida ${ }^{297}$.

A discussão no processo, a exposição de diferentes pontos de vista, não pode se perder por receio das partes de serem punidas. Elas não podem deixar de agir com liberdade, temerosas de que suas atitudes ou afirmações sejam interpretadas como contrárias à boa-fé e que, a partir disso, sejam aplicadas sanções. Isso, de fato, configuraria um autoritarismo contrário aos objetivos de se fazer incidir a boa-fé no processo, que é o de construir um Direito atento às necessidades de uma sociedade que busca ser democrática e solidária.

Por isso é que já alertamos quanto à necessidade de haver presunção de boa-fé no exercício de posições jurídicas processuais: deve-se pressupor que ambas as partes recorrem ao Judiciário e nele mantém sua demanda por causa de um legítimo estado de dúvida sobre o que é mais justo conforme os acontecimentos do mundo real que fizeram surgir um conflito, pressupondo-se, portanto, a existência de boa-fé subjetiva dos atuantes no processo. Há a pressuposição da boa-fé, até porque, o juiz conhece os fatos na medida do que foi a ele exposto pelas partes, cabendo-lhe ouvi-las pressupondo que a boa-fé está sendo observada.

O rompimento dessa premissa é consequência do comportamento das próprias partes: verificado, in casu, que condutas foram praticadas de modo a prejudicar a efetividade do processo, e sem que privilegiem qualquer outro princípio processual, elas devem ser reprimidas. Há sempre a escolha de como se agir no processo, quais posições serão exercidas e de que modo. Assim, uma vez adotado um comportamento, presume-se que houve boa-fé em sua prática, e que ele se coaduna com a cooperação de se obter uma tutela jurisdicional rápida e justa. Se, por sua vez, for constatado que houve afronta à boafé, daí então é quebrada a premissa anterior.

Note-se, aqui, o momento em que boa-fé sujetiva e objetiva se comunicam: presume-se a existência de boa-fé subjetiva de todos os sujeitos processuais. Entretanto, a partir das condutas por eles praticadas, exteriorizam-se comportamentos que serão valorados a despeito da perquirição do íntimo do agente, averiguando-se como existente a

${ }^{297}$ El abogado y la verdad, p. 284. 
boa-fé objetiva a partir da comparação entre o comportamento adotado e os padrões de conduta esperados $^{298}$.

A imposição da boa-fé objetiva não representa, portanto, feição autoritária do processo, assim como a visão publicista não se trata de um mito, mas consequência da consolidação de se entender por processo o instrumento estatal de solução de controvérsias, destinado a proferir decisões justas, a fim de trazer paz à sociedade a qual ele serve, pois o instrumento não está disponível conforme os interesses egoísticos das partes.

E aqui é que identificamos pontos de convergência com a própria crítica à boafé. Apesar de todas as afirmações contrárias à boa-fé, JUAN MONTEIRO AROCA conclui com uma proposta de interpretação ao art. 247 da Ley de Enjuiciamento Civil, que corresponde ao nosso art. 14, inc. II, do Código de Processo Civil, qual seja, aquela não a favor da boafé, mas sim contra a má fé, gerando, assim, um dever negativo, aquele de não se proceder conforme a má-fé ${ }^{299}$.

Tendo em vista a presunção de boa-fé, os sujeitos processuais, deixando de atuar de má-fé, não sofrerão quaisquer repressões, o que equivale a dizer que os sujeitos não devem agir de má-fé, tal como expôs o autor. No limite, não há diferenciação entre o que expusemos e o que a doutrina contrária à boa-fé dela espera.

A tudo isso, somem-se as ideias que passam a ser desenvolvidas sobre o processo cooperativo, que servirão para melhor delinearmos os limites de atuação de cada interveniente no processo, bem como as expectativas que permeiam a relação jurídica processual.

\subsection{A cooperação processual}

\footnotetext{
${ }^{298}$ Vale alertar, conforme já ressalvamos anteriormente (nota 87 supra), que o padrão de conduta esperado pode variar segundo as peculiaridades do meio em que se encontre o agente. Basta pensarmos nas peculiaridades regionais, culturais, econômicas em que se desenvolvem as mais diversas relações jurídicas, de modo que, conforme variável o ambiente, igualmente oscilante o padrão de comportamento esperado. Isso deve ser levado em conta quando da análise do comportamento convergente ou não com a boa-fé.

${ }^{299}$ Nas palavras do autor: "Creo, en consecuencia, que la regla debería enunciarse, no a favor de la buena fe, sino en contra de la mala fe, de modo que no se impusiera a la parte y a su abogado un deber positivo, sino um deber negativo, de abstención." (El proceso civil llamado "social" como instrumento de "justicia" autoritária, p. 163), e ainda em JUAN MONTERO AROCA, Sobre el mito autoritario de la "buena fe procesal", p. 352-353.
} 
A insuficiência da classificação que separa os sistemas processuais entre dispositivo e inquisitivo - classificação que adota a divisão do trabalho entre as partes e o juiz, a partir da análise de diferentes atos processuais, como critério divisor de águas ${ }^{300}$-, tem feito surgir discussões a respeito de um novo modelo processual, qual seja, o cooperativo $^{301}$.

De maneira bastante simplificada ${ }^{302}$, tem-se por modelo dispositivo ${ }^{303}$ aquele em que as partes assumem papel principal, cabendo a elas, e apenas a elas, a iniciativa da prática dos atos processuais apontados como ponto sensíveis, ou seja, a provocação do Judiciário, a delimitação do objeto do processo e da sentença, a revelação dos fatos relevantes ao julgamento e as iniciativas para a demonstração desses fatos, entre outros. A ideia central desse sistema envolve a compreensão do processo como instrumento destinado à resolução dos conflitos entre as partes, sendo delas o interesse de que se chegue ao resultado final com o maior número de elementos à disposição do julgador, de modo que elas providenciem esses elementos.

\footnotetext{
${ }^{300}$ Tais atos processuais são denominados como "pontos sensíveis" por BARBOSA MOREIRA, por servirem de critério diferenciador do modelo dispositivo para o inquisitivo. São eles, via de regra, a iniciativa da instauração do feito, a delimitação do objeto litigioso e do julgamento, o impulso processual, a formação do material de fato e de direito sobre o qual deve se embasar a sentença e a extinção do processo por ato dispositivo. (O problema da “divisão do trabalho"entre juiz e partes: aspectos terminológicos, p. 35).

${ }^{301}$ FREDIE DIDIER JR., Os três modelos de direito processual: inquisitivo, dispositivo e cooperativo, pp.218225. Sobre o tema da cooperação, $c f$. DANIEL MITIDIERO, Colaboração no processo civil.

${ }^{302}$ Não queremos nos aprofundar nessa classificação, por não ser imprescindível ao desenvolvimento do tema, mas, principalmente, por ser ela objeto de inúmeras críticas, dado que um sistema real jamais apresenta todas as características atribuídas a esses modelos processuais. Para a melhor compreensão dessa classificação, $c f$. JOHN ANTHONY JOLOWICZ,. Modelos adversarial e inquisitorial de processo civil, pp. 136147; LORENA BARREIROS, Fundamentos constitucionais do princípio da cooperação processual, pp. 65-166; Carlos Alberto Alvaro de Oliveira, Poderes do juiz e visão cooperativa de processo, pp. 56-58.

${ }^{303}$ Não se ignora a crítica feita ao uso da expressão "princípio dispositivo" para indicar qualquer situação em que haja subordinação do magistrado com relação à iniciativa das partes, crítica feita porque, em sua origem, a palavra "dispositivo" se referia às relações de direito material disponíveis, o que, aplicado ao direito processual, deveria fazer referência apenas às situações em que as partes teriam liberdade para, pela prática de atos processuais como renúncia, desistência e reconhecimento do pedido, disporem do direito material. Nesse sentido, José Roberto dos SANTOS BedAQue, Poderes instrutórios do juiz, pp. 87-97 e José CARLOS BARBoSA MOREIRA, O problema da "divisão do trabalho"entre juiz e partes: aspectos terminológicos, pp. 36-44. Não obstante, o "princípio dispositivo" é utilizado com frequência pela doutrina em geral como sinônimo de limitação da atividade do juiz à iniciativa das partes, e também frequente a conexão desse princípio com o sistema da commow law, v.g., "Segundo o princípio dispositivo, o juiz deve julgar a causa com base nos fatos alegados e provado pelas partes, sendo-lhe vedada a busca de fatos não alegados e cuja prova não tenha sido postulada pelas partes" (MAURÍCIO BARBIERI, Implicação do princípio dispositivo nos poderes instrutórios do juiz, p. 104). Daí a referência ao modelo dispositivo, o que também é admitido por BARBOSA MOREIRA, apesar de suas críticas quanto à utilização da expressão: "No momento, interessa-nos o emprego das locuções em matéria de obtenção de provas. Fala-se de 'princípio inquisitivo'em relação com a idéia de que é função do juiz obtê-las'; e de 'princípio dispositivo com a idéia de que esse trabalho incumbe às partes." (O processo civil contemporânteo: um enfoque comparativo, p. 42).
} 
O sistema oposto, por sua vez, posiciona o juiz como protagonista do processo $^{304}$. Ao invés de aguardar a iniciativa das partes, a maioria desses mesmos pontos sensíveis pode ser por ele praticada, tais como a instrução probatória e o impulso oficial ${ }^{305}$. O caráter público do processo é ressaltado de tal forma que um de seus escopos é o alcance da verdade real, o que permite ao juiz ampla liberdade de investigação de ofício dos fatos $^{306}$.

Diferentemente desses dois modelos, tem-se aquele cooperativo. A elaboração doutrinária que deu maior enfoque ao tema foi estimulada pela inserção do artigo $266 .{ }^{\circ} 1$ no Código de Processo Civil português, que se intitula como "princípio da cooperação" e que estabelece: "Na condução e intervenção no processo, devem os magistrados, os mandatários judiciais e as próprias partes cooperar entre si, concorrendo para se obter, com brevidade e eficácia, a justa composição do litígio".

A partir dele, surgem questões como (i) o que significa, em termos concretos, a imposição de um dever de cooperação entre as partes e o juiz - o que deve ser respondido principalmente à luz do estudo da legislação e doutrina portuguesa, diante do aprofundamento do estudo do tema naquele país, a partir das modificações legislativas vivenciadas; e (ii) se seria aplicável esse princípio a ordenamentos jurídicos que não possuem norma expressa nesse sentido, tal como o sistema processual civil brasileiro - o que já se adianta ser possível, o que explica as intervenções de nossa doutrina no tópico a seguir, já contribuindo para a delimitação das características do modelo cooperativo.

Tais questões merecem ser enfrentadas neste trabalho porque, a partir disso, será possível melhor delimitar as expectativas que envolvem o comportamento dos sujeitos processuais, para posterior relação dessas expectativas com a função do venire processual.

\subsubsection{Principais características}

\footnotetext{
${ }^{304}$ Igualmente, não faltam críticas à utilização do termo "inquisitivo", por também ter se desprendido de suas raízes históricas, sendo distorcido o atual siginificado a ele atríbuido, $c f$. MichELE TARUFFO, Poteri probatorio delle parti e del giudice in Europa, pp. 239-240.

${ }^{305}$ De uma maneira geral, mesmo nos sistemas tidos como inquisitivos, a provocação da demanda e a delimitação do objeto do processo e da sentença sempre estiveram a cargo das partes. Nesse sentido, LORENA BARREIROS, Fundamentos constitucionais do princípio da cooperação processual, p. 134. Como exceção, JUAN MONTERO AROCA dá notícia de que sistemas comunistas da União Soviética ignoravam por completo o princípio dispositivo: "Se niega la aplicación de los brocadores ne procedat iudex ex officio, con referencia al inicio del proceso, y ne eat iudez ultra petitia partium, sobre el contenido de la sentencia" (Sobre el mito autoritario de la "buena fe procesal", p. 311).

${ }^{306}$ FREDIE DIDIER JR., Os três modelos de direito processual: inquisitivo, dispositivo e cooperativo, p. 214.
} 
A premissa que deve ser esclarecida desde o início é a de que a grande maioria da doutrina que trata do tema não afirma a necessidade de as partes cooperarem espontaneamente entre $\mathrm{si}^{307}$, do que resultariam consequências dificilmente sustentáveis, como a de que elas houvessem que trazer ao processo, desde logo, alegações e provas que lhes fossem desfavoráveis. Ao se falar em cooperação, busca-se a alteração da relação que se estabelece entre o juiz e as partes, e vice-versa, sem que se chegue ao limite de cercear de maneira absoluta a liberdade das partes no processo ${ }^{308}$.

Partindo-se, portanto, dos estudos concernentes ao sistema processual português e do referido artigo $266^{\circ}, \mathrm{n}^{\circ} 1$ que estabelece o princípio da cooperação - para que, no item seguinte, averiguemos a viabilidade de transposição desse modelo ao nosso sistema -, a ideia central constantemente mencionada está na construção de uma “comunidade de trabalho" no processo ${ }^{309}$, estabelecendo-se uma nova divisão do papel das

${ }^{307}$ LUIZ MARINONI E DANIEL MitidiERO, O projeto do CPC, p. 73. Bastante ilustrativas as palavras de LINO ENRIQUE PALACIO a esse respeito: "De allí que un deber de no omitir alegaciones jurídicas o actos probatórios susceptibles de traducirse en exclusivo beneficio del adversario, sumado a la relativa expectativa de lograr una sentenia favorable, sería, sencillamente, la consagración de una torpeza o de una verdadera tontería" (Los deberes de lealtad, probidad y buena fe en el proceso civil, p. 815). CARLOS ALBERTO ALVARO DE OLIVEIRA é expresso nesse sentido: "Colaboração, entenda-se bem, não das partes entre si, pois estas ocupam posições necessariamente antagônicas, mas das partes com o juiz e do juiz com as partes. A ser estimulada, por exemplo, por técnicas, estabelecidas previamente pela lei, para o exercício dos poderes processuais com lealdade e boa-fé (v.g., arts. 14, 16 a 18 do Código de Processo Civil brasileiro), ou pela exigência de um contraditório forte" (Do formalismo ao processo civil, p. 194). Ainda na introdução do tema da cooperação, MiguEL TEIXEIRA DE SOUZA afirma que: “O processo jurisdicional não é imune à ideologia política, antes é profundamente influenciado por ela. A circunstância de esse processo decorrer perante um tribunal e de, por isso, colocar as partes em contacto directo com um órgão de soberania $\left(c f . \operatorname{art}^{\circ} 113^{\circ}, \mathrm{n}^{\circ} 1\right.$, CRP) determina que nele se reflitam as concepções fundamentais sobre as relações entre os indivíduos e o Estado. Essas relações devem, aliás, ser entendidas num duplo sentido: trata-se da posição do Estado perante o indivíduo, e, portanto, da medida da intervenção do Estado, através do tribunal, na autonomia do indivíduo; mas trata-se também da posição do indivíduo perante o Estado, pois que a parte que decide recorrer aos tribunais aceita submeter-se ao julgamento do poder jurisdicional" (Estudos sobre o novo processo civil, pp. 58-59). Da mesma maneira, afirma José LEBRE DE FREITAS que "Partes e juízes devem cooperar entre si para que o processo realize a sua função em prazo razoável” (Introdução ao processo civil, p. 164) e, por fim, MARIANA FRANÇA GOUVEIA afirma que o princípio da cooperação deve ser estudado por duas vertentes distintas: deveres das partes e deveres do juiz (Os poderes do juiz cível na acção declarativa, p. 52).

${ }^{308}$ Vale ressaltar que CÉSAR LEONARDO defende existir o dever de cooperação entre as partes, pois "afirmar que uma parte não pode ser obrigada a colaborar com a outra, mas somente para com o juiz e, concomitantemente, admitir que tal colaboração possa vir de encontro aos interesses da própria parte e, ainda, que o magistrado pode utilizar os frutos desta colaboração em detrimento dela, é questão de mera semântica. O resultado prático é o mesmo, pouco importando se a colaboração foi prestada ao juízo (beneficiando o adversário) ou à parte contrária (auxiliando o juízo)" (Contraditório, lealdade processual e dever de cooperação subjetiva, p. 82). Em convergência com esse último posicionamento, cf. ANDRÉ SANTORo CARRADITA, Abuso de situações jurídicas processuais no Código de Processo Civil, pp. 78-79.

${ }^{309}$ Miguel TeIXeIRA DE SouZA, Estudos sobre o novo processo civil, p. 62. No mesmo sentido, cf. CARLOS Alberto Alvaro De OliveIRA, Do formalismo no processo civil, pp. 115-116; ANTONIO DO PASSO CABRAL, Nulidades no processo moderno, 217. 
partes e do juiz, bem como da responsabilização dos sujeitos processuais em caso de desvio dos escopos do processo.

Ao ser utilizado o termo princípio, é aqui estudada a hipótese de a cooperação ser verdadeiro valor do ordenamento jurídico processual, norma de caráter fundante de tantas outras, implementando no sistema o valor do diálogo constante entre partes e juiz ${ }^{310}$.

\subsubsection{Cooperação das partes}

No que concerne ao papel das partes, não muito deve ser acrescentado, já que o dever delas cooperarem traduz-se no dever de litigarem de boa-fé ${ }^{311}$. O parâmetro a partir do qual se identifica um comportamento das partes como sendo em prol ou não da cooperação é a boa-fé, sendo ela averiguada em suas concepções objetiva e subjetiva ${ }^{312}$.

E o agir de boa-fé das partes significa, à luz do modelo cooperativo, por exemplo, prestar esclarecimentos pelo juiz quando assim ele solicitar e comparecer a todos os atos processuais a que forem chamadas ${ }^{313}$. Significa, ainda, afirmar a existência de um dever de veracidade no processo, sem, contudo, impor às partes um dever de completude.

Quanto ao dever de dizer a verdade, impossível sustentar se tratar do conceito de verdade objetiva, por diversas razões. A primeira delas está em que um conceito uníssono sobre um mesmo fato é inatingível; mesmo quando confrontadas duas pessoas que presenciaram um mesmo fato, interpretações distintas podem surgir, pois a percepção do mundo é sempre influenciada pelo subjetivismo de cada um. Por isso, atingir uma única verdade é, no campo próprio da filosofia, algo impossível, o que se aplica ao direito processual $^{314}$.

Em segundo lugar, tendo em vista a impossibilidade de se atingir a verdade absoluta, busca-se aquela relativa, qual seja, a máxima verdade atingível por meio do

\footnotetext{
${ }^{310}$ REINHARD GREGER, Cooperação como princípio processual, p. 125-132.

${ }^{311}$ Miguel TeIXEIRA DE SOUZA, Estudos sobre o novo processo civil, p. 62; MARIANA FRANÇA GoUVEIA, Os poderes do juiz cível na acção declarativa, p. 56; CÉSAR LEONARDO, Contraditório, lealdade processual e dever de cooperação subjetiva, p. 87.

312 Miguel TeIXEIRA DE SouZA, Estudos sobre o novo processo civil, p. 63 e BRUNELA VIEIRA DE VINCEZI, A boa-fé no processo civil, p. 170.

${ }^{313}$ LORENA BARREIROS, Fundamentos constitucionais do princípio da cooperação processual, pp. 194-195.

${ }^{314}$ EDUARDO CAMBI, A verdade processual objetivável e limites da razão jurídica iluminista, pp. 237-238.
} 
processo $^{315}$. Nesse contexto, já ressaltamos que na grande maioria das vezes as partes instauram um conflito a partir da dúvida que possuem a respeito de um tema, que somente será mais bem esclarecida ao final da instrução. Após a realização da fase instrutória, e, mais especificamente, depois de formada a convicção do magistrado sobre os fatos controvertidos, será possível analisar, de maneira retroativa, se as alegações das partes foram formuladas com a ciência prévia por elas mesmas de sua incompatibilidade com a verdade $^{316}$, e isso com base nos elementos de prova que elas já tinham à sua disposição. A noção de verdade processual a ser atingida, portanto, é indissociável das provas ${ }^{317}$.

Assim, a premissa de que as partes têm o dever de dizer a verdade deve ser compreendida como a vedação de se alegarem fatos que elas mesmas tenham convicção de serem inverídicos, ou seja, a visão subjetiva de verdade ${ }^{318}$. As partes podem afirmar quaisquer fatos, inclusive aqueles sobre os quais haja dúvida quanto a sua exata ocorrência, ressalvando-se aqueles que, sabidamente, estavam convictas de serem falsos ${ }^{319}$.

É reconhecida, porém, ainda sob o ponto de vista cooperativo, a liberdade de omissão, ou seja, a parte não está obrigada a relatar absolutamente todos os fatos circunstanciais à causa principal, pois, não se pode dela exigir que ofereça à parte contrária todos os elementos necessários ao julgamento em seu desfavor ${ }^{320}$. Daí a afirmação feita de

\footnotetext{
315 "Essa [a verdade] pode ser considerada relativa não no sentido de depender das opções individuais dos sujeitos que delas se ocupam (visto que, desse modo, cair-se-iam em um relativismo radical inaceitável), mas sim no sentido de que o conhecimento da verdade relaciona-se com o contexto em que surge, com o método com que se desenvolve sua busca e com a quantidade e a qualidade de informações de que se dispõe (e sob as quais tais conhecimentos fundam-se)" (MICHELE TARUFFO, Uma simples verdade: o juiz e a construção dos fatos, p. 105). No mesmo sentido DANIEL Mitidiero, Colaboração no processo civil, p. 108.

${ }_{316}$ FLÁVIO LUIZ YARSHELL, Antecipação da prova sem o requisito da urgência e direito autônomo à prova, pp. $155-157$.

317 "Portanto, para que a decisão seja justa, é preciso que o juiz conheça os fatos e suas repercussões jurídicas. Os fatos chegam ao conhecimento do juiz, através das alegações das partes, e, para que sejam capazes de persuadi-lo, devem ser verificados, quando necessário, através das provas. Assim, a certeza da justiça é resultado de um certame, isto é, da dialética entre as partes, com a participação do juiz e com a colaboração de todos aqueles (v.g., tesemunhas, peritos etc.) que são necessários para recompor, como se fosse um vivo quebra-cabeças, um momento da vida passada." (EDUARDO CAMBI, A verdade processual objetivável e limites da razão jurídica iluminista, p. 247).

${ }^{318}$ FLÁVIO LUIZ YARSHELL, Antecipação da prova sem o requisito da urgência e direito autônomo à prova, p. 155; Helena NAJJAR ABDO, $O$ abuso do processo, p. 136.

319 Deve se ressaltar, porém, que a verdade subjetiva diz respeito àquela a que as partes devem corresponder. Já o processo, em seu resultado final, conta com o conceito de verdade objetiva: não é aquela verdade absoluta, mas é aquela única a que se chega com base nos elementos que compõem o processo (MicHELE TARUFFO, Uma simples verdade: o juiz e a construção dos fatos, p. 106). E o posicionamento da busca pela verdade como escopo da prova a ser produzida no processo se faz fundamental para o modelo cooperativo, que tem a justiça como valor primordial a ser atingido (DANIEL MitidiERo, Colaboração no processo civil, p. 108).

${ }^{320}$ HELENA NAJJAR ABDO, O abuso do processo, p. 139. JOAN PICÓ I JUNOY afirma que "En consecuencia, las partes pueden omitir los datos que consideren perjudiciales para la tutela de sus intereses; así como también es correcto que eviten la aportación inicial de los documentos que se consideren inoportunos para su debida defensa." (El principio de la buena fe procesal, p. 157).
} 
que, apesar de existente o dever de veracidade, não há em nosso ordenamento um dever de completude, o que permite a omissão, principalmente para que as partes não sejam obrigadas a alegar fatos contra si mesmas ${ }^{321}$.

O direito à omissão, por sua vez, tem limites, pois não se pode omitir fato tão essencial que acabe por comprometer a veracidade dos demais fatos ${ }^{322}$.

Exemplo ilustrativo dessa hipótese e recorrente na doutrina é o do autor de uma ação de cobrança que, não obstante fundar sua pretensão em relação jurídica existente e verdadeira, deixa de mencionar o pagamento de uma das parcelas. Temos, ainda, um exemplo concreto em nossa atual legislação, qual seja, o art. 600, inc. IV, do Código de Processo Civil, que determina o enquadramento como ato atentatório à dignidade da Justiça da conduta do executado que, "intimado, não indica ao juiz, em 5 (cinco) dias, quais são e onde se encontram os bens sujeitos à penhora e seus respectivos valores" ${ }^{\text {}} 23$.

Conjugando os deveres de veracidade e completude, portanto, tem-se que as partes são livres para optarem por não revelarem fatos ou produzirem provas que lhes desfavoreçam, desde que isso não torne inverídicos os fatos efetivamente afirmados. E, ao escolherem por se manifestar, tem que observar o dever de veracidade, alegando somente aquilo que acreditarem ter acontecido ${ }^{324}$.

No campo probatório, o $519 .^{\circ}, \mathrm{n}^{\circ} 1$ do Código Civil Português estabelece o dever de cooperação a fim de que seja descoberta a verdade no processo: "Todas as pessoas, sejam ou não partes na causa, têm o dever de prestar a sua colaboração para a descoberta da verdade, respondendo ao que lhes for perguntado, submetendo-se às inspecções necessárias, facultando o que for requisitado e praticando os actos que forem determinados.",325

\footnotetext{
${ }^{321}$ AndRÉ SANTORo CARRAdita, Abuso de situações jurídicas processuais no Código de Processo Civil, p. 101.

322 "O que se sustenta hoje em dia é que a omissão é permitida desde que não incida em inveracidade". (HELENA NAJJAR ABDO, O abuso do processo, p. 140).

${ }^{323}$ Segundo LEONARDO CARNEIRO DA CUNHA, trata-se de verdadeiro dever do executado, daí o cabimento de imposição de multa uma vez inosbervado esse dever (A colaboração do executado no processo, p. 280).

324 KaETHE Grossmann, $O$ dever de veracidade das partes litigantes no processo civil laspecto doutrinário), p. 477. A ideia é bem traduzida por CÉSAR LEONARDO: "a parte que utiliza o seu ônus de afirmar, passa a ter o dever de falar a verdade" (Contraditório, lealdade processual e dever de cooperação subjetiva, p. 112).

${ }^{325}$ No Brasil, há dispositivo similar, que, apesar de mais genérico, permite que sejam extraídas as mesmas conclusões para o nosso sistema processual. Trata-se do art. 339 do Código de Processo Civil: "Ninguém se exime do dever de colaborar com o Poder Judiciário para o descobrimento da verdade".
} 
Com base nisso, a ausência do dever de completude acaba sendo relativizada. Afinal, ainda que a parte não tenha que trazer per si elementos probatórios desfavoráveis transpondo-se a ausência de dever de completude também ao momento probatório -, uma vez determinada a cooperar com a produção de alguma prova, ela não deve se esquivar, sob pena, por exemplo, de ter seu comportamento não colaborativo valorado em seu desfavor (consequência que será mais bem abordada no item 6.3 infra), ou ainda, de haver inversão do ônus da prova com relação ao fato que se pretendia demonstrar, o que resulta na possibilidade de um julgamento desfavorável à parte a quem inicialmente não incumbia demonstrar o fato controvertido ${ }^{326}$.

\subsubsection{Cooperação do órgão julgador}

Já com relação ao papel do juiz, há maior desenvolvimento do que significa essa cooperação em termos concretos - sem se esquecer de que a boa-fé é também a ele aplicável $^{327}$. É constantemente reproduzida a classificação entre quatro frentes de deveres do juiz para que ele exerça um papel cooperativo: dever de esclarecimento, dever de prevenção, dever de consulta e dever de auxílio ${ }^{328}$.

Em breve síntese, o dever de esclarecimento consiste no necessário diálogo a ser travado entre as partes e o juiz nas hipóteses em que este não depreende com facilidade o sentido das alegações daquelas, o que impede, por exemplo, o magistrado de indeferir a inicial sem provocar a manifestação do requerente destinada a esclarecer esses pontos obscuros $^{329}$. Assim, uma vez ainda em estado de dúvida, o magistrado deve buscar

\footnotetext{
${ }^{326}$ MigUel TEIXEIRA DE SouZA, Estudos sobre o novo processo civil, p. 64 . O autor ressalva que esse dever de cooperação probatória não se impõe às partes no caso de legítima razão para se recusar a colaborar, sendo essas razões aquelas elencadas no art. $519^{\circ}, \mathrm{n} .{ }^{\circ} 1$ do Código de Processo Civil Português: "A recusa é, porém, legítima se a obediência importar: a) Violação da integridade física ou moral das pessoas; b) Intromissão na vida privada ou familiar, no domicílio, na correspondência ou nas telecomunicações; c) Violação do sigilo profissional ou de funcionários públicos, ou do segredo de Estado, sem prejuízo do disposto no $\mathrm{n}^{\circ} 4$." (Ibidem, pp. 65-66). JOSÉ LEBRE DE FREITAS organiza os limites ao dever de cooperar com a produção de provas em dois tópicos: (i) os limites relacionados à observância de direitos fundamentais, e (ii) aqueles que se impõem diante do dever de sigilo. (Introdução ao Processo Civil, p. 165).

${ }^{327}$ Daniel Mitidiero, Colaboração no processo civil, p. 106; André PAgAni de Souza, Vedação das decisões-surpresa no processo civil, pp. 59-60.

${ }^{328}$ Miguel TeIXeIRA DE SouZA, Estudos sobre o novo processo civil, p. 65; LoRena BARReIRos, Fundamentos constitucionais do princípio da cooperação processual, pp. 198-199; DANIEL MITIDIERO, Colaboração no processo civil, p. 84; FREDIE DIDIER JR., O princípio da cooperação: uma apresentação, p. 77; Lúcio Grassi de GouveIa, Cognição Processual Civil, p. 372.

${ }^{329}$ Miguel TeIXEIRA DE SoUZA, Estudos sobre o novo processo civil, pp. 65-66. FrEDIE DIDIER JR., Fundamentos do princípio da cooperação no direito processual civil português, p. 15.
} 
esclarecimento das partes, que devem comparecer em juízo e prestar informações em qualquer fase do processo.

Pelo dever de prevenção, entende-se que o juiz deve expor às partes, no decorrer do processo, em que sentido vai se formando a sua convicção, apontando deficiências argumentativas e probatórias das partes a fim de que elas possam trazer novos elementos ao processo ${ }^{330}$. É qualificado como dever simplesmente assistencial do magistrado, pois não impõe qualquer conduta recíproca às partes ${ }^{331}$.

O dever de consulta também é assistencial, e sua essência está ligada à ideia de que o juiz deve expor às partes, observando-se o contraditório, todas as questões do processo, inclusive aquelas que ele, tradicionalmente, pode conhecer de ofício; tal exigência visa a evitar a decisão surpresa, aquela proferida sem qualquer discussão prévia com as partes ${ }^{332}$.

E, por fim, no que se refere ao dever de auxiliar, trata-se de buscar facilitar o exercício de posições jurídicas processuais pelas partes, em caso de obstáculos de difícil superação $^{333}$. Como exemplo, deve o Estado-juiz colaborar com a produção de provas pelas partes, fornecendo meios coercitivos para remover eventuais impedimentos que tornem a produção da prova, pela parte, bastante dificultada ${ }^{334}$. Não há motivos para não estender esse dever também às partes, o que de fato é providenciado pelo artigo $519 .^{\circ}$ do Código de Processo Civil português.

Isso sem falar nos poderes instrutórios do juiz, que também são reconhecidos e quistos pelos postulados desse modelo cooperativo ${ }^{335}$. Por meio da atividade oficiosa do juiz em âmbito probatório, permite-se que partes díspares em termos econômicos ou com representações técnicas desequilibradas possam ser igualadas. Permite-se colocar à disposição do julgador mecanismos que ampliem sua cognição e suas possibilidades de se atingir o resultado mais justo ao caso concreto $^{336}$. Permite-se, portanto, a efetivação da

\footnotetext{
${ }^{330}$ FREDIE DIDIER JR., Fundamentos do princípio da cooperação no direito processual civil português, p. 19; PAUlo HOFFMAN, Saneamento compartilhado, pp 51-53.

${ }^{331}$ Miguel TeIXEIRA DE SOUZA, Estudos sobre o novo processo civil, p. 66.

332 PAUlo HofFMAn, Saneamento compartilhado, pp. 53-54; Miguel TeIXEIRA DE SoUZA, Estudos sobre o novo processo civil, p. 67.

${ }^{333}$ Miguel TeIXEIRA DE SoUZA, Estudos sobre o novo processo civil, p. 67.

${ }^{334}$ PAUlo HofFMAn, Saneamento compartilhado, p. 55.

335 DANIEl Mitidiero, Colaboração no processo civil, p. 110; CARlos Alberto Alvaro De OliveIRA, Poderes do juiz e visão cooperativa de processo, p. 73.

${ }^{336}$ José RoBerto dos SANTOS BeDAQUE, Poderes instrutórios do juiz, pp. 97-107.
} 
comunidade de trabalho ${ }^{337}$, viabilizando que o juiz atue e promova a cooperação ainda quando o interesse das partes se revele contrário a essa finalidade.

A imposição de deveres ao magistrado faz com que ele assuma posição hierarquicamente igual à das partes, havendo um único momento de assimetria entre eles, que é o momento decisório, seja de questões processuais, seja de questões materiais ${ }^{338}$. Os demais atos processuais, porém, devem todos ser praticados em colaboração, evitando-se a surpresa, a quebra de confiança, as atitudes que nada contribuam para o bom andamento e bom resultado do processo.

A ausência de assimetrias e a necessária participação das partes e do juiz revela a concepção processual que corresponde ao modelo organizacional da sociedade em Estado Democrático de Direito ${ }^{339}$. Assim, sem que a relação entre direito e sociedade seja despercebida, o processo cooperativo é tido como aquele que melhor se coaduna com os ditames do Estado Democrático, que, ao preconizar valores como a solidariedade, a participação da população e a justiça, impõe que esses mesmos valores sejam observados no processo.

5.2.1.3. Eficácia imediata do modelo cooperativo

Fixadas as principais características do modelo processual cooperativo, principalmente a partir do que se observa no ordenamento português, surge a questão da eficácia desse modelo, o que, em verdade, discute a possibilidade de haver eficácia imediata do princípio da cooperação. A doutrina diverge nesse ponto, encontrando-se quem afirma que tudo isso não passa de um modelo ideal, fundado em um princípio

\footnotetext{
337 "Si intende che l'attribuizione di poteri sufficientemente determinati, che consentano al giudice di promovere l'attività necessaria per la preparazione di quei poteri é idoneo a dar vita ad una comunione di lavoro, quale qui si prospetta, soltanto se sia assienrata l'effettiva, simultanea partecipazione dei soggetti privati" (EDUARDO GRASSO, La collaborazione nel processo civile, p. 597).

${ }_{338}^{338}$ DANIEL MitidiERo, Colaboração no processo civil, p. 81.

339 DANIEL Mitidiero, Colaboração no processo civil, p. 80. A relação entre a organização do Estado e cooperação é identificada na obra de MIGUEL TEIXEIRA DE SOUSA: "A preocupação de coadunar a estrutura e os fins do processo civil com os princípios do Estado social de direito e de garantir uma legitimação externa às decisões do tribunal esteve igualmente presente na reforma do processo civil: a sujeição do processo a um princípio de cooperação entre as partes e o tribunal, a acentuação da inquisitoriedade do tribunal e a atenuação da preclusão na alegação de factos, e, finalmente, a prevalência da decisão relativa ao mérito sobre a decisão de forma" (Estudos sobre o novo processo civil, p. 62).
} 
carecedor de normas que lhe confiram a concretude necessária à aplicabilidade, e, de outro lado, afirmam alguns a eficácia imediata do princípio da cooperação.

A posição dominante dos autores portugueses é no sentido de o princípio carecer de concretização legislativa, de modo que somente quando regulado por normas concretas, o princípio da cooperação será dotado de imperatividade ${ }^{340}$. Por outro lado, há quem afirme a eficácia imediata da cooperação, demonstrando-se que a divergência se dá pelas diferentes concepções de princípio de que partem os autores ${ }^{341}$.

Rechaçando a concepção de princípio como incapaz de produz per si conteúdo normativo, FREDIE DIDIER se embasa em muitos autores dedicados exclusivamente ao tema para afirmar que o princípio é espécie de norma ${ }^{342}$, que contém imperatividade com eficácia ora direta, ora indireta, conforme a necessidade ou não de se valerem de outro subprincípio ou regra, respectivamente, para serem eficazes ${ }^{343}$. E toda vez que ele assumir eficácia direta, o princípio funciona como elemento integrador do sistema, preenchendo os vazios normativos com o valor que ele contém ${ }^{344}$. O princípio da cooperação, portanto, tem eficácia direta quando ausente qualquer regra específica sobre determinada situação jurídica processual, impondo que a interpretação sobre ela se dê em observância à cooperação.

Mas é possível identificar elementos normativos já existentes que se coadunam com o valor cooperação, de modo que, nessas hipóteses, o princípio assume eficácia

\footnotetext{
${ }^{340}$ É o que aponta FREDIE DIDIER JR., Fundamentos do princípio da cooperação no direito processual civil português, p. 50. Ilustra bem esse posicionamento o pensamento de PAULA Costa E Silva, Acto e processo, pp. 590-592. A autora afirma que "o art. 266/1 não é passível de aplicação imediata. Requer uma concretização.” (Idem, p. 591). Tal premissa é bastante frágil considerando o estágio atual dos estudos sobre os princípios. Especificamente sobre os direitos fundamentais, VIRGílio AFONSO E SILVA sugere que "todos os direitos fundamentais são restringíveis e todos os direitos fudamentais são regulamentáveis" (Direitos fundamentais: conteúdo essencial, restrições e eficácia, p. 246), ou seja, o fato de uma norma fundamental carecer de concretude legislativa não lhe retira a eficácia imediata.

${ }^{341}$ FREDIE DIDIER JR., Fundamentos do princípio da cooperação no direito processual civil português, pp. 50-56. No mesmo sentido: "Assim, o princípio da cooperação deve ser tido como uma norma jurídica de aplicabilidade imediata, cogente, impositiva de condutas às partes e ao juiz, independentemente de regulação legal dessas condutas" (LORENA BARREIROS, Fundamentos constitucionais do princípio da cooperação processual, pp. 190-191).

${ }^{342}$ FREDIE DIDIER JR., Fundamentos do princípio da cooperação no direito processual civil português, p. 50.

${ }^{343}$ FREDIE DIDIER JR., Fundamentos do princípio da cooperação no direito processual civil português, p. 51. A classificação entre eficácia direta e indireta é de HUMBERTO ÁVILA, Teoria dos princípios, pp. 97-98.

${ }^{344}$ FREDIE DIDIER JR., Fundamentos do princípio da cooperação no direito processual civil português, pp. 51-52. O exemplo dado por DIDIER sobre o tema nos é de grande interesse: "Se não há regras expressas que, por exemplo, imputem ao órgão jurisdicional o dever de manter-se coerente com os seus próprios comportamentos, protegendo as partes contra eventual venire contra factum proprium do órgão julgador, o princípio da cooperação garantirá a imputação desta situação jurídica passiva. Ao integrar o sistema jurídico, o princípio da cooperação garante o meio (imputação de uma situação jurídica passiva) necessário à obtenção do fim almejado (o processo cooperativo)" (Ibidem, p. 52).
} 
indireta. Essa eficácia indireta pode advir da identificação de um princípio ainda mais amplo do que o da cooperação, assumindo este o papel de subprincípio e servindo à definição do princípio mais abrangente, ou ainda, as regras podem assumir esse papel de definição do princípio $^{345}$.

No primeiro caso, o devido processo legal e a boa-fé atuam como sobreprincípios em relação à cooperação, sendo esta um meio de defini-los e concretizálos. Já no segundo caso, basta identificar regras processuais que privilegiem a cooperação, como é o caso do artigo $3 .^{\circ}$, n. 3 do CPC Português (que determina a manifestação das partes sobre questão de fato ou de direito que o juiz pode conhecer de ofício) e do artigo $508 .^{\circ}$, n. 1 (que trata do dever de prevenção, determinando ao juiz que convide as partes a melhorarem suas alegações, por exemplo) ${ }^{346}$.

E há, ainda, a função interpretativa e bloqueadora dos princípios. No caso da cooperação, o princípio serve para interpretar normas menos amplas à luz do valor por ele imposto, bem como para bloquear a aplicação de normas incompatíveis com a ideia de cooperação ${ }^{347}$.

As premissas de que parte o autor sobre o conceito de princípio são aquelas com as quais já tivemos oportunidade de concordar (Capítulo 3.2.1.1. infra). Não há porque limitar a eficácia do princípio da cooperação no ordenamento jurídico português: por se tratar de um princípio, previsto de maneira expressa no Código de Processo Civil, e ainda identificados princípios e regras que com ele são convergentes, há motivos suficientes para se sustentar sua imediata aplicabilidade. Servirá o princípio, pois, como parâmetro de interpretação e integração do sistema, além de definir sobreprincípios, ser definido por regras e bloquear a eficácia das regras que com ele se choquem.

Por fim, diante da expressão da cooperação no Código de Processo Civil português, tratando-se de conceito vago a ser preenchido conforme o caso concreto, defende-se a existência de verdadeira cláusula geral, que remete ao princípio da cooperação (tal como a boa-fé é, em nosso ordenamento, uma cláusula geral que elucida

\footnotetext{
${ }^{345}$ FREDIE DIDIER JR., Fundamentos do princípio da cooperação no direito processual civil português, pp. 53-54.

${ }^{346}$ FREDIE DIDIER JR., Fundamentos do princípio da cooperação no direito processual civil português, pp. 53-54.

${ }^{347}$ FREDIE DIDIER JR., Fundamentos do princípio da cooperação no direito processual civil português, pp. 54-55.
} 
um princípio $)^{348}$. Isso tem a vantagem de permitir que a repressão à ausência de cooperação se estabelece conforme as exigências de cada caso concreto ${ }^{349}$.

\subsubsection{Nova divisão do trabalho aplicável ao ordenamento brasileiro}

A existência de um princípio da cooperação no ordenamento jurídico português, portanto, fez com que fosse identificada uma nova divisão do trabalho entre as partes e juiz, visão essa que, por diferir dos modelos inquisitivo e dispositivo há muito desenvolvidos, justifica a defesa de um novo modelo.

Afinal, aqui não se fala mais em protagonismo das partes ou do juiz, mas sim da comunidade de trabalho em que todos os sujeitos processuais assumem papéis igualmente relevantes ${ }^{350}$. E dessa diferente premissa decorrem diversas consequências, na medida em que cada ato processual deve ser construído por todos, e até mesmo a decisão, que é atividade exclusiva do juiz, passa a ser resultado dessa cooperação.

Em outras palavras, toda a divisão do trabalho no curso do processo deve ser vista de maneira distinta, privilegiando-se a ampla participação das partes e do juiz, no exercício de um contraditório não meramente formal, mas responsável por garantir que essa participação se efetive.

Mas o fator de maior distinção deste modelo com relação aos demais está nas posições jurídicas processuais que o magistrado assume. Não mais passivo e não mais

\footnotetext{
${ }^{348}$ FREDIE DIDIER JR., Fundamentos do princípio da cooperação no direito processual civil português, p. 69.

349 “'A compreensão do princípio da cooperação do Direito processual português não pode prescindir de todas essas conquistas. Principalmente para que se perceba que as consequências normativas para o desrespeito ao princípio da cooperação não precisam ser típicas: pode-se construir o efeito jurídico mais adequado ao caso concreto. A infração ao princípio da cooperação pode gerar invalidade do ato processual, preclusão de um poder processual (talvez até mesmo uma suppressio), dever de indenizar (se a infração vier acompanhada de um dano), direito a tutela inibitória, sanção disciplinar etc. Essa parece ser a solução para o problema mais recorrente no manejo das cláusulas gerais processuais: saber se a consequência normativa para o descumprimento da norma que dela se extrai” (FREDIE DIDIER JR., Fundamentos do princípio da cooperação no direito processual civil português, p. 71).

${ }^{350}$ FrEDIE DIDIER JR., Fundamentos do princípio da cooperação no direito processual civil português, p. 47. Para LORENA BARREIROS, "O modelo cooperativo traduz, nesse passo, um novo paradigma na divisão de tarefas entre partes e juiz. A ideia central desse modelo consiste na transformação do processo em uma verdadeira comunidade de trabalho (Arbitsgemeinschaft), capaz de albergar, ao mesmo tempo, um magistrado de feição atuante na condução do processo e partes igualmente ativas, colaboradoras para o alcance do resultado final pretendido: a justa solução da controvérsia em tempo razoável. Sem desprezar a realidade de que o processo envolve, como regra, interesses conflitantes, busca estabelecer uma disputa leal e capaz de conduzir a um resultado substancial e processualmente justo" (Fundamentos constitucionais do princípio da cooperação processual, p. 179).
} 
como superior às partes, o exercício de sua função passa a ser visto sem se falar em equidistância das partes, porque não se privilegia a distância, mas sim a proximidade, o diálogo, a colaboração e a não surpresa ${ }^{351}$.

Em meio a tantas oportunidades de diálogo e de participação, pode-se imaginar que a celeridade do processo fique comprometida. Daí a relevância de se tornar qualificada a participação dos sujeitos processuais, sempre em atenção à boa-fé processual. Desse modo, restringe-se a ampla possibilidade de manifestação toda vez que ela for exercida com desvio de finalidade, sem que o objetivo principal tenha sido contribuir para o resultado justo, mas apenas postergar a solução ou distorcê-la em benefício de interesses egoísticos.

Com relação à aplicabilidade do modelo desde logo em nosso ordenamento, apesar de inexistir, atualmente, princípio equivalente àquele previsto pelo art. $266^{\circ}$ do Código de Processo Civil português, a doutrina dedicada ao tema da cooperação defende sua aplicabilidade imediata, principalmente à luz de nosso modelo constitucional contemporâneo. E isso por duas principais razões: (i) pelo princípio da cooperação poder ser extraído de outros princípios reconhecidos em nosso ordenamento; (ii) por existirem regras que são capazes de dar concretude à cooperação, ou melhor, de confirmar sua eficácia indireta.

O modelo cooperativo se apoia nos princípios constitucionais da democracia, do contraditório, do devido processo legal, da boa-fé e da solidariedade ${ }^{352}$. Essas são suas bases constitucionais, e, mais do que isso, justamente para efetivar esses princípios no processo, o modelo cooperativo é apontado como o mais adequado. Nota-se, portanto, a relação de reciprocidade entre o modelo cooperativo e tais princípios: estes são o fundamento para aquele, ao passo que aquele é o modelo que melhor compreende estes.

No que diz respeito à democracia, ela representa a ideia essencial de participação do povo nas diferentes manifestações do poder estatal, dentre as quais, o jurisdicional ${ }^{353}$. Assim, se é constitucionalmente prevista a meta democrática, o processo não deve dela se esquivar, sendo o modelo cooperativo aquele que mais proporciona a

\footnotetext{
${ }^{351}$ LORENA BARREIROS, Fundamentos constitucionais do princípio da cooperação processual, p. 171; FREDIE DIDIER JR. O princípio da cooperação: uma apresentação, p. 76.

${ }^{352}$ LORENA BARREIROS, Fundamentos constitucionais do principio da cooperação processual, pp. 231-232. FREDIE DIDIER JR., Fundamentos do princípio da cooperação no direito processual civil português, p. 55, nota 86.

${ }^{353}$ Carlos Alberto Alvaro de Oliveira, Poderes do juiz e visão cooperativa de processo, p. 62.
} 
participação das partes no processo, ao vedar que sejam tomadas decisões sem consultálas, ao se estimular a participação delas em um plano simétrico à atuação do juiz ${ }^{354}$.

Tal participação, por sua vez, se corporifica pela concretização do princípio do contraditório $^{355}$. Por meio dele, garante-se a efetiva participação das partes, para que elas influenciem na formação das decisões judiciais ${ }^{356}$, em uma soma de esforços para solucionar um conflito ${ }^{357}$. Ele é o responsável por relativizar o princípio iura novit curia e fazer o magistrado indicar quais os caminhos que estão sendo percorridos em seu raciocínio decisório, antes que ele surpreenda as partes com uma decisão distinta de qualquer discussão jurídica que tenha sido travada nos autos ${ }^{358}$, ou seja, o juiz é também sujeito do contraditório, sendo seu dever garantir observância dele em todas as fases processuais $^{359}$.

Em homenagem ao contraditório, chamam-se as partes a se manifestar sobre questões cognocíveis de ofício, ou seja, o diálogo intrínseco ao modelo cooperativo se estabelece por meio do contraditório. E isso até mesmo para se garantir a legitimação das decisões: a cooperação, por meio do contraditório, e como forma de concretizar a participação democrática, permite que as decisões sejam bem aceitas pela sociedade ${ }^{360}$.

A novidade do contraditório visto sob a perspectiva da cooperação está, principalmente, em fazer do juiz um sujeito desse princípio. Dele passam a ser exigidas condutas em prol do diálogo, sem que sejam tomadas decisões de modo a surpreender a $\operatorname{parte}^{361}$.

\footnotetext{
${ }^{354}$ LORENA BARREIROS, Fundamentos constitucionais do princípio da cooperação processual, pp. 232-235.

${ }^{355}$ Carlos Alberto Alvaro de Oliveira, Poderes do juiz e visão cooperativa de processo, p. 64.

${ }^{356}$ Sobre o contraditório e a cooperação, CARLOS Alberto Alvaro DE OliveIRA afirma que "a idéia de cooperação, além de implicar, sim, um juiz ativo, colocado no centro da controvérsia, importará senão o restabelecimento do caráter isonômico do processo pelo menos a busca de um ponto de equilíbrio. Esse objetivo impõe-se alcançado pelo fortalecimento dos poderes das partes, por sua participação mais ativa e leal no processo de formação da decisão, em consonância com uma visão não autoritária do papel do juiz e mais contemporânea quanto à divisão do trabalho entre órgão jurisdicional e as partes." (Poderes do juiz $e$ visão cooperativa de processo, p. 62).

${ }^{357}$ ANTONIO DO PASSO CABRAL, Nulidades no processo moderno, p. 219.

${ }^{358}$ Carlos Alberto Alvaro de Oliveira, Poderes do juiz e visão cooperativa de processo, p. 68. Sobre o tema, vale conferir a obra de ANDRÉ PAGANI DE SOUZA, Vedação das decisões-supresa no processo civil. ${ }^{359}$ CÉSAR LEONARDO, Contraditório, lealdade processual e dever de cooperação subjetiva, pp. 51-52.

${ }^{360}$ BRUNELA VIEIRA DE VINCEZI, A boa-fé no processo civil, p. 44. Sobre a cooperação e a legitimação das decisões, cf. também LORENA BARREIROS, Fundamentos constitucionais do princípio da cooperação processual, p. 184.

${ }^{361}$ LORENA BARREIROS, Fundamentos constitucionais do princípio da cooperação processual, p. 276. Para ANDRÉ PAGANI DE SOUZA, trata-se de verdadeiro dever do juiz o de garantir e participar do diálogo, evitando a decisão-surpresa (Vedação das decisões-surpresa no processo civil, pp. 94-98).
} 
A relação entre cooperação e devido processo legal é consequência da constatação de que, não obstante ser um princípio muito antigo, o conteúdo do que se entende por devido processo legal foi se transformando ao longo do tempo ${ }^{362}$. Assim, a concepção de devido processo legal não pode prescindir, atualmente, de ter o seu conteúdo preenchido também pela cooperação, entendendo-se por devido processo aquele que garanta a efetivação da "comunidade de trabalho". Isso permitirá que o conteúdo do devido processo se adeque às necessidades do caso concreto. Permitirá a adaptação do procedimento para melhor atender ao que se pleiteia, desde que alertadas as partes quanto à alteração, chamando-as a participar da composição do procedimento ${ }^{363}$.

A boa-fé serve de embasamento para a cooperação na medida em que impõem deveres anexos às relações jurídicas firmadas. Essa concepção, que veio do direito obrigacional civil, transpõe-se ao direito processual, de modo que, pela necessária observância da boa-fé objetiva no processo, extraem-se os deveres anexos a que nos referimos, ou seja, o dever de consulta, auxílio, prevenção e esclarecimento ${ }^{364}$.

Assim, se a cooperação se dá para que se atinja o resultado final esperado de um negócio jurídico, ela se faz necessária para que se atinja o resultado final desejável ao processo: a entrega de uma tutela jurisdicional que se coadune com os parâmetros de justiça, em tempo razoável ${ }^{365}$. A boa-fé é, portanto, o parâmetro de conduta imposto aos sujeitos processuais para que suas condutas sejam convergentes com a cooperação, não sendo demais ressaltar, como veremos mais adiante, que ela é também parâmetro para

${ }^{362}$ FREDIE DIDIER JR., Fundamentos do princípio da cooperação no direito processual civil português, pp. 72-79.

${ }^{363}$ LORENA BARREIROS, Fundamentos constitucionais do princípio da cooperação processual, p. 246.

${ }^{364}$ FREDIE DIDIER JR., afirma que "Certamente, não é mera coincidência o fato de a sistematização do princípio processual da cooperação, feitas pelas doutrinas alemã e portuguesa, invocar os deveres de proteção, auxílio e esclarecimento. O dever de consulta, também identificado como conteúdo do princípio da cooperação, é variante processual do dever de informar, aspecto do dever de esclarecimento, compreendido em sentido amplo. A construção teórica e jurisprudencial do princípio processual da cooperação não prescinde de todo desenvolvimento do tema feito no direito obrigacional. Convém que a doutrina do direito processual não ignore essa circunstância e, assim, possa valer-se de todo esse repertório teórico e jurisprudencial, que não é pequeno nem insignificante." (Fundamentos do princípio da cooperação no direito processual civil português, p. 101).

365 "Se no âmbito obrigacional os deveres de cooperação orbitam o cumprimento da prestação (propósito da relação obrigacional), no âmbito processual eles giram em torno da solução do objeto litigioso (propósito do processo), com justiça e brevidade, como, aliás, está muito bem posto no n. 1 do art. $266 .^{\circ}$ do CPC português." (FREDIE DIDIER JR., Fundamentos do princípio da cooperação no direito processual civil português, pp. 101-102). E ainda: "Concebido en efecto el proceso judicial contencioso como un entramado de conductas que interfieren organizadamente en la creación de la norma individual contenida en la sentencia final, requiere inevitablemente una tarea común - no individual o autónoma - de sus partícipes, encaminada a superar el conflicto que lo originó. De modo, por consiguiente, que es el valor jurídico de cooperación el que infunde sentido a tales conductas, y en cual encuentran fundamento válido los deberes de lealtad, probidad y buena fe." (LINO ENRIQUE PALACIO, Los deberes de lealtad, probidad y buena fe en el proceso civil, p. 815). 
identificação de desvios de finalidade nas condutas processuais e, assim, pemite que seja identificado o abuso do processo, que, uma vez reprimido, acaba por privilegiar a cooperação.

E, por fim, no que se refere à relação entre cooperação e solidariedade, a premissa é a de que o princípio constitucional da solidariedade, ao qual já nos referimos (Capítulo 3.2.3. supra), também é norma a ser observada no processo. A busca por se concretizar uma sociedade solidária passa também pelo mecanismo estatal de resolução de conflitos: não mais uma forma de privilegiar apenas interesses individuais, o Processo se torna espaço de atuação das partes e do órgão estatal para o alcance de objetivo comum ${ }^{366}$.

A cooperação é o modelo que privilegia o desenvolvimento solidário do instrumento; não pela ilusória ideia que já repelimos de que as partes cooperarão espontaneamente entre si, mas pela imposição de deveres aos sujeitos processuais que permitam que o melhor resultado seja obtido; não aquele melhor para uma das partes, mas considerando todos os escopos da jurisdição ${ }^{367}$. Ao buscar que se deixem de lado os interesses egoísticos - mais uma vez: ainda que não espontaneamente - para a consecução dos resultados esperados, a cooperação acaba por privilegiar a solidariedade.

Além de todas essas bases constitucionais, outro argumento em prol da exigência desse modelo desde logo em nosso ordenamento está na identificação de normas infraconstitucionais processuais que têm uma ideologia cooperativa como fundamento

\footnotetext{
366 “Assim, ao contrário do que pode parecer à primeira vista, a realização dos escopos do processo não visa somente ao bem do Estado e à concretização de suas políticas, mas a toda a coletividade, criando um ambiente propício ao exercício dos direitos individuais e coletivos. Ademais, observa-se que, além das garantias do processo, a Constituição conferiu a todos o direito fundamental a um Estado solidário; mais especificamente, está no art. $3^{\circ}$, inciso I, da Carta Política brasileira, que 'constituem objetivos fundamentais da República Federativa do Brasil: construir uma sociedade livre, justa e solidária'. Assim, todos os princípios contidos na garantia maior do devido processo legal devem ser realizados no e para o processo cumprir seus escopos fundamentais, mas também é preciso no processo e pelo processo zelar por uma sociedade solidária" (BRUNELA VIEIRA VICENZI, A boa-fé no processo civil, pp. 49-50).

367 "De fato, um texto normativo constitucional, por mais efetivo que pretenda ser, jamais seria capaz de impor a alguém que desenvolvesse um sentimento de amor ao próximo ou de solidariedade. A norma que se há de extrair do texto constitucional não pode, pois, dirigir-se à criação de estados psíquicos ou emotivos neste ou naquele indivíduo ou grupo social. Mas pode, sim, compelir este ou aquele indivíduo ou grupo a agir como faria se, de fato, tais sentimentos existissem. O alcance do estado de coisas ambicionado pelo principio da solidariedade pressupõe, assim, o estabelecimento de deveres jurídicos imponíveis aos indivíduos, limitando, em certa medida, seu espaço de liberdade em prol de que seja atingido objetivo comum. A solidariedade passa a ser um padrão de comportamento, uma forma de agir exigida pelo ordenamento jurídico;" (LORENA BARREIROS, Fundamentos constitucionais do princípio da cooperação processual, pp. 237-238).
} 
valorativo $^{368}$. É dizer, há regras infraconstitucionais que se coadunam com a cooperação, permitindo-se que delas se extraia a eficácia indireta da cooperação a qual nos referimos.

Como exemplos dessa realidade, destacam-se, ainda na fase inicial do procedimento ordinário, os artigos 284 e 295, inciso V, do $\mathrm{CPC}^{369}$. Aquele, ao garantir a oportunidade de o autor emendar a inicial a fim de sanar irregularidades, e este, que permite a adaptação do procedimento erroneamente indicado para o correto de modo a evitar o indeferimento da inicial, são exemplos de deveres de prevenção do juiz. Nessa modalidade de dever, ainda, tem-se o art. 599, inc. II, do CPC, que permite ao juiz alertar as partes de que suas condutas configuram ato atentatório da dignidade da justiça antes de lhes aplicar a sanção correspondente, bem como, já em âmbito recursal, a possibilidade de sanar eventuais nulidades se elas forem supríveis por meio da realização de diligências (art. 515, §4, do CPC) ${ }^{370,371}$.

No que se refere ao dever de consulta, consta do art. $40, \S 4^{\circ}$ da Lei $n$. 6.830/1980 a necessidade de o magistrado ouvir a Fazenda antes do reconhecimento de ofício da prescrição intercorrente ${ }^{372}$, realidade que, infelizmente, ainda não se observa a todas as demais questões cognocíveis de ofício pelo juiz, ao menos não de maneira expressa na lei.

O dever de esclarecimento encontra expressa manifestação nos artigos 342 e 440 do Código de Processo Civil, que permitem ao juiz determinar o comparecimento das partes para interrogá-las, bem como diligenciar a fim de inspecionar pessoas e coisas para obter esclarecimentos sobre determinado fato. Isso sem falar na própria previsão dos embargos de declaração, cujo cabimento envolve sanar obscuridades e contradições, de modo a viabilizar o esclarecimento das decisões judiciais (artigo 535, inciso I, do CPC) ${ }^{373}$.

Os deveres de auxílio são exemplificados pelo artigo 655-A do CPC, em que se permite ao juiz uma atividade auxiliadora na execução, ao viabilizar o contato direito com

\footnotetext{
368 Sobre o tema, FREDIE DIDIER JR afirma que "O direito processual civil brasileiro contém regras semelhantes a praticamente todas as regras que concretizam o princípio da cooperação no direito português. Há regras brasileiras que não correspondem a regras portuguesas, assim como a recíproca também é verdadeira" (Fundamentos do princípio da cooperação no direito processual civil português, p. 55).

369 DANIEL MitidiERo, Colaboração no processo civil, p. 123.

${ }^{370}$ LORENA BARREIROS, Fundamentos constitucionais do princípio da cooperação processual, pp. 224-225.

${ }^{371}$ Devemos destacar, ainda, o entendimento jurisprudencial convergente com a cooperação, na modalidade de prevenção em âmbito recursal, de que a ausência de peças essenciais facultativas no agravo de instrumento não deve gerar a imediata inadmissibilidade, devendo-se conferir às partes a oportunidade de juntar os documentos faltantes após a interposição. Nesse sentido, cf. REsp 1102467/RJ, Rel. Ministro MASSAMI UYEDA, CORTE ESPECIAL, julgado em 02/05/2012, DJe 29/08/2012.

${ }^{372}$ LORENA BARREIROS, Fundamentos constitucionais do princípio da cooperação processual, p. 226.

${ }^{373}$ LORENA BARREIROS, Fundamentos constitucionais do princípio da cooperação processual, pp. 226-227.
} 
autoridades do sistema bancário a fim de encontrar ativos do executado, para torná-los indisponíveis de modo a garantir a satisfação do crédito do exequente ${ }^{374}$.

A fase instrutória é marcada pela cooperação nos moldes do que dispõe o art. 519..$^{\circ}$ do Código de Processo Civil português, apesar da pouca atenção que a doutrina e a jurisprudência conferem à disciplina do tema. Trata-se dos artigos 339 a 341, que determinam a colaboração dos sujeitos do processo para o descobrimento da verdade, impondo dever às partes de comparecerem quando sua presença for requisitada, de submeterem-se a inspeções judiciais e de praticarem o ato determinado ${ }^{375}$.

Vê-se, portanto, que já existem normas expressas no Código de Processo Civil vigente que afirmam a possibilidade da aplicação imediata do princípio da cooperação em nosso ordenamento. Tal possibilidade se tornará ainda mais evidente se aprovado, em definitivo, o projeto de novo Código de Processo Civil, que, ainda em sua última versão, prevê expressamente a cooperação nos moldes do artigo 266. ${ }^{\circ}$ do Código de Processo Civil Português, ou seja, na forma de princípio expresso que manifesta o caráter fundante da cooperação na operacionalização das normas processuais: "Art. $6^{\circ}$ Todos os sujeitos do processo devem cooperar entre si para que se obtenha, em tempo razoável, decisão de mérito justa e efetiva." ${ }^{376}$.

De todo modo, vale esclarecer que, no contexto atual da nossa legislação, apesar de já existirem normas que convergem para os fins da cooperação, ainda assim não prescindimos de um novo modelo de divisão do trabalho entre partes e juiz a ser consolidado para que os velhos entendimentos, ainda divergentes da cooperação, sejam repensados.

Um desses velhos entendimentos a ser superado é o de que um ato processual, quando praticado em desatenção à forma prevista em lei, não pode ser corrigido ainda que não transcorrido o prazo total para seu exercício, pela incidência da preclusão consumativa $^{377}$. O tema será analisado no Capítulo 7.2. infra, mas desde já se adianta o quão divergente da visão cooperativa é esse entendimento, principalmente porque a alteração do ato processual dentro do prazo legal não fere expectativas de terceiros, que

\footnotetext{
${ }^{374}$ LORENA BARREIROS, Fundamentos constitucionais do princípio da cooperação processual, p. 227.

375 JosÉ MOACYR DORETTO NASCIMENTO, A boa-fé objetiva e o processo civil, p. 82.

${ }^{376}$ Versão disponível em < http://www.migalhas.com.br/arquivos/2014/3/art20140326-01.pdf>.

377 Sobre o tema, $c f$. JOSÉ ROBERTO DOS SANTOS BEDAQUE, Efetividade do processo e técnica processual, pp. 145-149.
} 
desde sempre estavam cientes da existência de um prazo limite, somente a partir do qual podem existir expectativas de inalterabilidade.

Não se observa, ainda, a necessária manifestação das partes com relação a pontos que o magistrado pode conhecer de ofício, sendo comum a existência de "decisõessurpresa" na rotina judiciária. Isso vale não só para o reconhecimento de prescrição e decadência, institutos comumente citados com exemplos de questões de ofício, mas também para a aplicação de presunções simples e utilização de provas atípicas, de modo a proteger a não surpresa ${ }^{378}$. Assim, as questões de ofício devem ser compreendidas como aquelas que podem ser conhecidas sem provocação das partes, mas a decisão sobre elas deve se embasar no necessário contraditório. ${ }^{379}$

Um ponto interessante a ser analisado à luz do princípio da cooperação é aquele referente à distribuição do ônus da prova. É comum a afirmação, mesmo sob o viés da cooperação, de que, justamente para se evitar a surpresa, o ônus da prova serve de regra de julgamento e também de conduta, de modo que a distribuição tenha que ser feita em momento anterior à instrução probatória, conferindo às partes a oportunidade de se desincumbirem dos ônus a elas atribuídos ${ }^{380}$.

Entretanto, pensando nas premissas estabelecidas de que as partes devem cooperar para a obtenção da verdade possível de ser atingida no processo, bem como considerando o dever de se comportarem em observância à boa-fé, melhor se coaduna com o dever de cooperação a prescindibilidade de se alertar sobre a inversão do ônus da prova em momento prévio ao julgamento, estimulando-se, assim, que as partes tragam desde logo todas as informações e provas que possam auxiliar na formação do convencimento do magistrado. Dessa forma, sequer será necessária a invocação do ônus da prova, regra de julgamento que deve ser utilizada apenas nos casos de carência probatória sobre os pontos controvertidos $^{381}$.

${ }^{378}$ CÉSAR LEONARDO, Contraditório, lealdade processual e dever de cooperação subjetiva, p. 132.
${ }^{379}$ ANDRÉ PAGANI DE SOUZA, Vedação das decisões-surpresa no processo civil, p. 141.
${ }^{380}$ CÉSAR LEONARDO, Contraditório, lealdade processual e dever de cooperação subjetiva, p. 141.
${ }^{381}$ Nesse mesmo sentido era o entendimento parcial do Superior Tribunal de Justiça, ilustrado pelo voto a
seguir destacado da Min. NANCY ANDRIGHI: RECURSO ESPECIAL. DIREITO DO CONSUMIDOR.
INVERSÃO DO ÔNUS DA PROVA. MOMENTO. SENTENÇA. POSSIBILIDADE. REGRA DE
JULGAMENTO. OFENSA AO PRINCÍPIO DO CONTRADITÓRIO. INEXISTÊNCIA. 1. A jurisprudência
do STJ não se pacificou quanto à possibilidade de o juízo inverter o ônus da prova no momento de proferir a
sentença numa ação que discuta relação de consumo. 2. O Processo Civil moderno enfatiza, como função
primordial das normas de distribuição de ônus da prova, a sua atribuição de regular a atividade do juiz ao
sentenciar o processo (ônus objetivo da prova). Por conduzirem a um julgamento por presunção, essas regras
devem ser aplicadas apenas de maneira excepcional. 3. As partes, no Processo Civil, têm o dever de 
Nessa hipótese, ou seja, sem alertas sobre a inversão em momento anterior, não haveria incertezas às partes, pois desde o início do processo judicial elas estariam cientes da possibilidade de inversão somente ao final do julgamento e que, portanto, deveriam se esforçar para trazerem todos os elementos necessários ao convecimento do juízo conforme a versão por elas apresentada. Tal esforço é pressuposto de um modelo cooperativo de processo, não se vislumbrando qualquer prejuízo decorrente de que somente ao final do processo serem invocadas as regras de distribuição do ônus, as quais trarão à tona as consequências da não desincumbência de um encargo que sempre existiu, qual seja, o de contribuírem com todos os elementos necessários a melhor formar a convicção do julgador.

A interpretação do sistema processual à luz do princípio da cooperação e da boa-fé objetiva é o que justifica defendermos, por exemplo, a impossibilidade de se alegar a impenhorabilidade de bem disponível ${ }^{382}$ volutariamente indicado à penhora ${ }^{383}$. Trata-se de caso típico de venire contra factum proprium como veremos oportunamente, mas desde já se adianta que o afastamento da impenhorabilidade tem como razão de ser a proteção da confiança daquele exequente que aceitou a substituição da penhora, ou do contratante que aceitou um imóvel dado voluntariamente em garantia.

colaborar com a atividade judicial, evitando-se um julgamento por presunção. Os poderes instrutórios do juiz lhe autorizam se portar de maneira ativa para a solução da controvérsia. As provas não pertencem à parte que as produziu, mas ao processo a que se destinam. 4. O processo não pode consubstanciar um jogo mediante o qual seja possível às partes manejar as provas, de modo a conduzir o julgamento a um resultado favorável apartado da justiça substancial. A ênfase no ônus subjetivo da prova implica privilegiar uma visão individualista, que não é compatível com a teoria moderna do processo civil. 5. Inexiste surpresa na inversão do ônus da prova apenas no julgamento da ação consumerista. Essa possibilidade está presente desde o ajuizamento da ação e nenhuma das partes pode alegar desconhecimento quanto à sua existência. 6. A exigência de uma postura ativa de cada uma das partes na instrução do processo não implica obrigá-las a produzir prova contra si mesmas. Cada parte deve produzir todas as provas favoráveis de que dispõe, mas não se pode alegar que há violação de direito algum na hipótese em que, não demonstrado o direito, decida o juiz pela inversão do ônus da prova na sentença. 7. Recurso especial conhecido e improvido. (REsp 1125621/MG, Rel. Ministra NANCY ANDRIGHI, TERCEIRA TURMA, julgado em 19/08/2010, DJe 07/02/2011). Infelizmente, o entendimento restou superado a partir do REsp 802.832, que fixou como necessária a inversão do ônus por decisão interlocutória, idealmente a ser proferida na fase saneadora. No mesmo sentido das ideias que sustentamos, cfr: MARCELO PACHECO MACHADO, Ônus estático, ônus dinâmico e inversão do ônus da prova, pp. 306-307.

${ }^{382}$ Sendo o bem indisponível do ponto de vista do direito material, nos parece que qualquer tentativa de dele se dispor é incapaz de gerar confiança. Não é possível, pois, afastar uma indisponibilidade de direito material por meio da conduta contraditória no processo, como veremos no item 8.6. infra.

${ }^{383}$ Nesse sentido é o pensamento de FREDIE DIDIER JR.: "O executado oferece à penhora um bem imóvel que guarnece a residência (impenhorável, também). Em seguida, opõe embargos à execução, pedindo a invalidação da penhora, em razão da impenhorabilidade daquele bem. O órgão jurisdicional não pode acolher esse pedido, pois o oferecimento do bem à penhora é incompatível com a impugnação dessa mesma penhora. Houve preclusão lógica, em razão do comportamento contraditório (aplicação do princípio da proibição do venire contra factum proprium)" (Subsídios para uma teoria das impenhorabilidades, p. 34). 
Esses e muitos outros exemplos ilustram o motivo pelo qual se faz necessária a aplicação dos princípios da boa-fé objetiva e da cooperação no Processo, de modo a revisar a maneira conforme enxergamos alguns institutos, imprimindo à prestação jurisdicional os valores sem os quais ela não pode ser efetiva.

\subsection{As reais expectativas no processo}

Por meio do estudo dos temas da boa-fé objetiva e da cooperação, buscou-se demonstrar que o sistema processual está pronto para exigir dos sujeitos que dele participam um comportamento qualificado, convergente com seus principais escopos, existindo mecanismos legislativos suficientes para incentivar um comportamento cooperativo, bem como para afastar condutas que inobservem os parâmetros de conduta ditados pela boa-fé.

Com isso, não se pretende afirmar que as partes esperam, umas das outras, a cooperação, a honestidade e a veracidade sempre. Tal afirmativa seria minimamente ingênua, e bem distante da realidade ${ }^{384}$. O que se afirma é que o sistema tem essa expectativa de comportamento qualificado dos sujeitos processuais, sendo um dos objetivos do processo incentivar a colaboração entre eles e resguardar a confiança emanada no desenvolver da relação jurídica processual ${ }^{385}$.

Em outras palavras, e principalmente no que diz respeito ao exercício de posições jurídicas processuais pelas partes, não se espera que elas espontaneamente adotem comportamentos convergentes com a boa-fé. Mas os pressupostos fixados como escopos do processo, a compreensão de ser ele um instrumento público, bem como a identificação de mecanismos legislativos existentes com a finalidade de reprimir condutas

\footnotetext{
384 “De otro modo, existen riesgos que no siempre se quieren correr. El primero es convertir al proceso en lo que no es, porque si se aplican reglas de cortesía y honestidad exigible a las partes, habría que cambier sortilegios ambivalentes como establece la escritura, que convierte las afirmaciones volcadas en el papel en lo único que se puede atender, porque de otro modo, 'no está en el mundo'. Así las cosas, mientras las partes luchan entre sí con lealtad, probidad y buena fe, en concreto lo hacen en un juego sofista donde la realid es distante y la confianza de la gente prácticamente nula". (OSVALDO GOZAínI, El principio de la buena fe en el proceso civil, p. 891). PAULA COSTA E SILVA, após descrever o "tipo ideal de parte" como aquele que apenas informa ao tribunal os fatos, sem tentar persuadí-lo, afirma que "se este tipo ideal se pode mostrar necessário como indicação dada pelo legislador aos diferentes operadores judiciários quanto àquilo que deles requer, dificilmente se pode esperar que o operador real tenha condições para se aproximar daquele operador ideal". (Acto e processo, p. 112).

385 "Não obstante, se a cooperação não for buscada voluntariamente, pode e deve ser exigida de todos" (ANTONIO DO PASSO CABRAL, Nulidades no processo moderno, p. 220).
} 
contrárias à boa-fé e à cooperação, permitem-nos identificar uma expectativa do sistema processual com relação a seus sujeitos, de que entre eles se firmará e se desenvolverá uma relação de colaboração. E, ainda que haja motivos para desconfiança, deve-se confiar nos mecanismos do sistema para repressão de condutas que firam tais expectativas.

Ainda que não seja possível esperar da parte adversa um comportamento cooperativo, a identificação de mecanismos legislativos incentivadores de tal comportamento permite que as partes esperem a observância da boa-fé como qualificadora dos atos processuais. Quando faltar confiança na parte adversa, deve-se confiar na atuação do juiz como responsável por coibir condutas indesejadas. Quando faltar confiança na atuação do juiz, deve-se confiar que ele também se submete aos deveres de boa-fé e cooperação, de modo que suas condutas também serão reprimidas pelo sistema toda vez que deixarem de cooperar com o método de trabalho. E a tutela da confiança significa afastar surpresas no curso da relação jurídica processual, pois surpreender as partes significa perder a fé na administração da justiça ${ }^{386}$.

Nesse contexto, é possível afirmar a existência de legítimas expectativas surgidas no curso da relação jurídica processual, e que devem ser preservadas sob pena de serem rompidas as premissas do processo permeado pela boa-fé objetiva e pela visão cooperação de divisão do trabalho entre partes e juiz ${ }^{387}$. É justamente esse contexto que permite se falar em venire processual.

Ainda que não tenha recebido grande atenção da doutrina, o instituto foi percebido pela jurisprudência como mecanismo apto a coibir quebras de expectativas processuais, rupturas do padrão de comportamento ditado pela boa-fé objetiva processual e pela expectativa do sistema de que haverá cooperação na busca de um resultado em comum entre partes e juiz. Isso explica, por exemplo, o motivo pelo qual o venire protege tanto expectativas surgidas do comportamento das partes quanto aquelas decorrentes da atuação do magistrado.

\footnotetext{
${ }^{386}$ Nas palavras de CARLOS AlBERTO ALVARO DE OliveiRA: “Aliás, a problemática não diz respeito apenas ao interesse das partes, mas conecta-se intimamente com o próprio interesse público, na medida em que qualquer surpresa, qualquer acontecimento inesperado, só faz diminuir a fé do cidadão na administração da justiça." (Poderes do juiz e visão cooperativa de processo, p. 64).

387 BRUNELA VIEIRA DE VINCEZI afirma que, por meio da observância da boa-fé objetiva no processo, "respeita-se também a legítima expectativa criada na contraparte e nos membros da sociedade, decorrente do comportamento adotado ou até pela imagem do obrigado" (A boa-fé no processo civil, p. 159).
} 
O venire posiciona-se, portanto, como uma ferramenta em âmbito processual para que sejam repelidas condutas contrárias à boa-fé e à cooperação, buscando otimizar a aplicação de ambos os princípios.

Nesse ponto, indaga-se o porquê de a jurisprudência se fazer valer desse instituto que originalmente foi pensado pelo Direito Civil, quando já existem tantas figuras processuais que, em um primeiro momento, servem justamente para coibir condutas indesejáveis ao processo. É que o que buscarmos responder a seguir. 


\section{COMPORTAMENTO PROCESSUAL CONTRADITÓRIO: VENIRE EM CONFRONTO COM OUTROS INSTITUTOS PROCESSUAIS}

Como veremos mais detalhadamente no Capítulo 8 infra, o fato de na relação jurídica processual estar presente o Estado-juiz traz peculiaridades diversas, fator de maior relevância para justificar o estudo especializado do venire nessa seara jurídica. E, também em razão disso, a adoção de comportamentos contraditórios é abarcada por categorias jurídico-processuais diversas, sendo necessário estudá-las para melhor delinear todas as formas de consequências jurídicas pelo exercício de situações jurídicas processuais contraditórias.

Para que a mesma advertência não se torne repetitiva no início de cada subitem seguinte, é preciso esclarecer que o enfrentamento dos temas infra indicados tem por escopo apenas identificar eventuais semelhanças e diferenças entre eles e o venire.

Não é nossa pretensão apresentar uma revisão aprofundada de cada tema, expondo todas as controvérsias doutrinárias existentes, diante do fracasso que isso seria: cada item poderia servir de objeto de estudos próprios - o que, aliás, já foi feito, servindonos justamente desses trabalhos para nos auxiliar na tarefa de, sucintamente, entender cada figura, e compará-la com o venire -, sendo superficial a tentativa de compreendê-las todas, ao mesmo tempo, com profundidade.

Assim, todos os tópicos a seguir apresentam uma estrutura básica em comum: dá-se o conceito, as principais características, e a comparação com o venire, sempre nos baseando na doutrina majoritária sobre cada tema, ressaltando eventuais divergências que sejam pertinentes ao nosso objeto de estudo. Tudo isso para que consigamos, ao final, melhor delinear os contornos que qualificam a vedação de comportamentos processuais contraditórios e suas possíveis consequências.

\subsection{Abuso do processo}

Há quem vislumbre no Processo Civil um campo ainda mais vasto para o exercício abusivo de direitos se comparado com outras áreas do direito, tendo em vista o 
conflito de interesses quase inerente ao processo, o que não se verifica necessariamente em outros ramos do direito - como no Direito Civil, em que frequentemente é identificado o acordo de vontades de modo a proporcionar a celebração de negócios jurídicos ${ }^{388}$. Assim, a divergência faz com que as partes tenham maior propensão a abusarem do processo.

À semelhança do que foi estudado no item 3.2.2. supra, o abuso do processo se dá quando o exercício de situações jurídicas processuais se faz de modo a desvirtuar sua função, contrariando a finalidade das normas (sejam normas expressas, sejam aquelas normas éticas do sistema jurídico ${ }^{389}$ ).

Para configuração do chamado abuso do processo, é necessário, primeiramente, (i) o exercício de uma determinada situação jurídica processual (ii) por um dos sujeitos legitimados por lei a agir, ou seja, por um dos sujeitos da relação jurídica processual. E isso porque se um terceiro estranho à relação jurídica processual exerce uma situação jurídica processual sem ser o titular dela, há configuração de um ilícito processual, e não um abuso propriamente dito ${ }^{390}$.

Disso se conclui, ainda, que qualquer um dos titulares de situações jurídicas processuais pode praticar abusos do processo, sejam os sujeitos parciais (partes, seus representantes legais, advogados, Ministério Público, terceiros intervenientes) ou os imparciais, incluindo-se, nessa última categoria, não só os magistrados como também os auxiliares da justiça ${ }^{391}$.

Em decorrência dessa legitimação dos sujeitos processuais para agir, ou seja, pelo fato de o abuso ter por objeto situações jurídicas processuais autorizadas, é também caraterística do abuso (iii) a aparência de legalidade, pois, se ausente o desvio de finalidade, nada seria além de um simples ato processual legitimado pelo ordenamento ${ }^{392}$. De outro lado, se não houvesse essa aparência, e a violação à norma processual fosse expressa, novamente se configuraria um ilícito processual, e não um abuso do processo ${ }^{393}$.

\footnotetext{
${ }^{388}$ CASTRO FILHO, Abuso do direito no processo civil, pp. 31-32.

389 Gualberto LuCAs Sosa, Abuso de derechos procesales, p. 50; CASTRo Filho, Abuso do direito no processo civil, p. 21

${ }^{390}$ HelenA ABDO, O abuso do processo, p. 63.

${ }^{391}$ HELENA ABDO, O abuso do processo, pp. 48-49.

392 Helena ABDO, O abuso do processo, p. 100; JORGE AMERICANO, Do abuso do direito no exercicio da demanda, p. 8.

393 "En primer lugar, debe haber una vulneración de la finalidad perseguida por la norma procesal, sin que exista una infracción directa de la misma. Por ello, como acabo de indicar, la prohibición del abuso del derecho nunca debe entrar en juego cuando estamos ante límites legales expresos o formales de un derecho, en cuyo caso, su ejericio será ilícito por vulnerar dichos límites, y no por existir un abuso del derecho" (JOAN PICó I JUNOY, El principio de la buena fe procesal, p. 104). Nas palavras de HUMBERTO THEODORO JÚNIOR,
} 
Ainda fundamental para a caracterização do abuso do processo (iv) o desvio de finalidade, o qual se configura quando houver "disparidade existente entre os meios de que o sujeito se utiliza e os fins por ele almejados"394. Isso faz com que o simples erro na prática de determinada conduta, ou a omissão dela, não seja suficiente para configurar abuso do processo. Para tanto, é preciso verificar a ocorrência do desvio de finalidade ${ }^{395}$.

Para que se compreenda a noção do desvio de finalidade e suas hipóteses de incidência, é preciso retomar como premissa a relativa liberdade dos sujeitos processuais e o espaço de manobra que eles têm à sua disposição para atuarem no processo.

A garantia constitucional à liberdade (art. 5º caput, da Constituição Federal), uma vez aplicada ao processo, permite afirmar que os sujeitos processuais são, por princípio, livres para escolherem praticar ou não determinado ato processual, bem como para optarem pela maneira em que essa prática ocorrerá. Paralelamente, existem limites a essa liberdade, principalmente no que diz respeito ao processo, cuja legalidade das formas implica regulamentação prévia do lugar, tempo e modo de se praticarem determinados atos.

Uma vez desrespeitados esses parâmetros limitativos da conduta, o ato processual não apresenta todas suas condições de eficácia, mas isso não significa dizer que haverá abuso. A inobservância dos requisitos de tempo, modo e lugar gerará, via de regra, inaptidão do ato para produzir os efeitos dele esperados, sem espaço para se falar em abuso com base nessa simples afronta às normas processuais.

\footnotetext{
"O abuso do direito, embora seja por seu fim um ilícito, não se confunde com o ato simplesmente violador da lei. $\mathrm{O}$ ato que ofende frontalmente a lei não tem sequer a aparência da legalidade. É incapaz de produzir efeitos porque atrita frontalmente com a vontade legal. $\mathrm{O}$ agente, de forma alguma, teria uma legitimidade de praticá-lo. Já o ato abusivo se prende a uma faculdade legal que, em princípio, o agente detinha. O vício reside na forma com que o titular da faculdade a utilizou, desviando-a de sua natural objetividade." (Abuso de direito processual no ordenamento jurídico brasileiro, p. 111).

394 Helena ABDo, O abuso do processo, p. 91. Elena CATAlano define o fenômeno como requisito teleológico do abuso do processo, que significa "l'impiego di uno strumento processuale per uno scopo diverso da quello istituzionalmente attribuito al rimedio medesimo" (L'abuso del processo, p. 39).

395 “Como já se adiantou, uma noção clara e lógica é a de que a mera violação de uma regra processual não acarreta per se a prática de abuso do processo. Esse tipo de violação é plenamente justificável, pois representa apenas um erro da parte, que é sujeita às consequências normais previstas para aquele ato. (...) Todavia, se a parte se vale desse tipo de expediente para tumultuar o feito, certamente sua conduta contém um elemento que a diferencia da mera violação de uma regra processual. E esse elemento, sempre lembrado em tema de abuso, quer direta, quer indiretamente, é o desvio de finalidade" (HELENA ABDO, O abuso do processo, p. 87-88). TARUFFO, por sua vez, afirma que o erro grosseiro lesivo à contraparte pode configurar abuso do direito: "Violar uma regra processual não é abusivo per se em nenhum caso, uma vez que nem todo erro é um abuso (como muitos repórteres salientaram). No entanto, um injustificado erro processual grosseiro pode ser considerado como abusivo, especialmente quando seus efeitos são demasiadamente nocivos para qualquer outra parte, sem falar quando o direito é conscientemente mal aplicado apenas com o fim de molestar ou prejudiciar a outra parte" (MICHELE TARUFFO, Abuso de direitos processuais, p. 160).
} 
De outro lado, afastadas as hipóteses de inobservância direta da forma, a conjugação entre tais limites e a garantia da liberdade resulta reconhecer um "“espaço de manobra', dentro do qual as partes podem exercer as respectivas situações jurídicas subjetivas (faculdades, ônus, poderes e deveres)" ${ }^{\text {396 }}$. É no trânsito por este espaço de manobra que as partes podem praticar abusos do processo: dentro das limitações legais, o sujeito processual pode agir com liberdade, porém, esta não é irrestrita ou absoluta, e encontra sua limitação justamente na noção de desvio de finalidade ${ }^{397}$.

Pressupondo esse espaço de manobra, é possível o exercício livre de situações jurídicas processuais, as quais são praticadas buscando-se uma finalidade. Como exemplo, há produção de uma prova visando a demostrar a veracidade dos fatos afirmados, assim como a interposição de um recurso funda-se na crença do desacerto de uma decisão, que deve ser reformada com base nas regras jurídicas aplicáveis ao caso. Nesses exemplos, a finalidade que impulsiona a prática do ato é convergente com aquela previamente vislumbrada pelo legislador quando da legitimação das situações processuais aos sujeitos do Processo, inexistindo, assim, qualquer irregularidade.

Às vezes, porém, a finalidade vislumbrada pelos sujeitos, quando do exercício de uma situação jurídica processual, difere daquela prevista pelo sistema ${ }^{398}$. Nesse caso, configura-se o desvio de finalidade ${ }^{399}$.

Por fim, questiona-se se necessário observar o dano decorrente do abuso como requisito para sua caracterização no processo. Deve se entender por dano não apenas prejuízos patrimoniais, mas também, e principalmente, a potencialização do dano marginal, o eventual surgimento do dano moral, e o dano à administração da justiça ${ }^{400}$. Assim, ainda que não sejam identificados danos às partes, o comportamento que, por meio

\footnotetext{
${ }^{396}$ HeLENA ABDO, O abuso do processo, p. 77.

397 “....a liberdade de que gozam os sujeitos processuais é relativa e não absoluta, de forma que o sujeito que a exerce não se exime das consequências desfavoráveis oriundas das escolhas que fizer" (HELENA ABDO, $O$ abuso do processo, p. 101). No mesmo sentido, cf. JORGE AMERICANO, Do abuso do direito no exercicio da demanda, p. 30.

${ }^{398}$ HeLENA ABDO, $O$ abuso do processo, p. 91.

399 Segundo ANDRÉ SANTORO CARRADITA, "a chave para identificar o abuso de uma situação jurídica processual está no fim visado por seu titular: se ele coincidir com os escopos para os quais aquele específico instrumento processual foi concebido, o uso é legítimo; se houver uma distorsão da finalidade própria do instrumento processual, há abuso (Abuso de situações jurídicas processuals no Código de Processo Civil, p. 149).

${ }^{400}$ HelEnA ABDO, O abuso do processo, pp. 124-126.
} 
do desvio de finalidade, afete o desempenho da jurisdição, já configura um dano processual $^{401}$.

Como bem ressalta ANDRÉ SANTORO CARRADITA, “o fato de o comportamento processual abusivo afetar, invariavelmente, o interesse público é importante porque faz com que o improbus litigator mereça sempre ser sancionado" 402 , independentemente de dano provocado às partes contrárias ou a terceiros, o que eventual e cumulativamente pode ocorrer.

Assim, uma das principais peculiaridades no que concerne ao abuso do processo está em que o prejuízo dele decorrente não atinge somente a contraparte ou terceiros, mas também o Estado ${ }^{403}$ que, como vimos, tem interesse na prestação efetiva da tutela jurisdicional. Isso implica admitir a intervenção judicial de modo a reprimir abusos processuais ainda que não tenha havido prejuízo à parte contrária.

Disso se conclui que mais acertado não apontar o dano como um requisito autônomo e necessário à caracterização do abuso do processo, mas apenas como uma consequência natural do abuso: o prolongamento desnecessário do processso faz surgir um dano in re ipsa ${ }^{404}$.

Assim como se observou no Direito Civil (item 3.2.2. supra), também no que diz respeito ao abuso do processo os estudos divergem sobre a necessidade do elemento subjetivo para sua configuração. Tanto que, justamente por causa dessa discordância, firmaram-se as teorias subjetiva ou psicológica, a objetiva ou finalista e a teoria mista ${ }^{405}$.

Os subjetivistas entendem necessária a presença de um "elemento intencional, ou seja, impõe-se que o agente tenha consciência de que o seu direito, inicialmente

401 CÉSAR LEONARDO, Contraditório, lealdade processual e dever de cooperação subjetiva, p. 69; HUMBERTO THEODORO JÚNIOR, Abuso de direito processual no ordenamento jurídico brasileiro, p. 115.

${ }^{402}$ Abuso de situações jurídicas processuais, p. 166.

403 CAStro Filho, Abuso do direito no processo civil, p. 32; Helena ABDO, O abuso do processo, p. 99; FABIO MILMAN, Improbidade processual, p. 65.

${ }^{404}$ CARlos Daniel PASTOR, El abuso procesal, p. 59. Helena ABDo afirma a imprescindibilidade do dano para configuração do abuso do processo, mas suas conclusões acabam não divergindo do que expusemos, afirmando a autora que "independentemente da verificação de outros prejuízos, o abuso do processo provoca invariavelmente danos à eficiência da administração da justiça. Esse dado é confirmado na doutrina, que é totalmente concorde nesse ponto. Conclui-se, pois, que, por qualquer ângulo que se analise a questão, o abuso do processo sempre provoca danos, tanto de caráter patrimonial, como moral, quer em relação ao particular ou ao próprio Estado" (Abuso do processo, p. 126).

${ }^{405}$ Será exposta uma visão simplificada dessas teorias, ressaltando-se que, dentro de cada uma delas, há divergências que as dividem em diferentes correntes. A teoria subjetiva, por exemplo, diverge entre os graus de culpabilidade necessários para configuração do abuso do direito; a teoria objetiva divide-se entre aqueles que consideram abuso no exercício anormal do direito ou no desvio de finalidade do direito ( $c f$. RUI STOCO, Abuso de direito, p. 69). No mesmo sentido, ver HelENA ABDO, O abuso do processo, pp. 37-43. 
legítimo e secundum legis, ao ser exercitado, desbordou para o excesso ou abuso" ${ }^{406}$. Nessa subjetividade, inclui-se não só a intenção de prejudicar, mas também assumir esse risco ou deixar de prevê-lo quando assim se deveria proceder.

Já os adeptos da teoria objetiva entendem ser desnecessária a configuração da intencionalidade de lesionar o direito alheio. Basta observar uma conduta desviada da finalidade segundo a qual foi originariamente vislumbrada, ou quando fere, nos termos do Código Civil, a finalidade social e econômica, os bons costumes, e a boa-fé $e^{407}$.

Como se supõe, a teoria mista sugere que a melhor caracterização do ato abusivo envolve a necessidade de investigação do elemento subjetivo da intencionalidade, mas também não dispensa o aspecto objetivo, o desvio da finalidade ${ }^{408}$. Por vezes, essa mistura dos aspectos subjetivo e objetivo é exigida conforme o abuso identificado, ou seja, para alguns atos processuais seria exigida a intenção de prejudicar para sua caracterização como abuso, ao passo que outros abusos poderiam se configurar objetivamente ${ }^{409}$. Ou ainda, pela teoria mista se defende que o elemento intencional seja aferido objetivamente $^{410}$.

O tema é bastante controverso. A única certeza é a de que, para aqueles que entendem ser necessária a presença do elemento subjetivo, sua comprovação é frequentemente um entrave à aplicação do abuso do processo. É por isso que, na prática, não obstante a defesa pela demonstração de dolo ou culpa, o modo de comprová-los é atenuado, aproximando-se, no limite, da noção objetiva ${ }^{411}$.

\footnotetext{
${ }^{406}$ RUI STOCO, Abuso de direito, p. 68. Admitindo também a corrente subjetiva, destaca-se: ANGEL LANDONI SosA, El abuso de los derechos procesales, p. 142; OSVALDO GOZAínI, La conducta en el proceso, p. 109 e 111.

${ }^{407}$ IVANA MARÍA AIRASCA, Reflexiones sobre la proscripción del abuso del derecho en el proceso, pp. 99100 JORGE PEYRANO, Otro principio procesal: la prscripción del abuso del derecho en el campo del proceso civil, pp. 191-192.

408 Em síntese: "Enquanto para os subjetivistas seria imprescindível a presença de dolo ou culpa para a configuração do auto abusivo (era considerada a intenção de prejudicar e a ausência de proveito para o agente com a prática do ato, o que acabava por igualar o ato abusivo ao ato ilícito), os finalistas, de seu turno, abstraíam o elemento subjetivo da caracterização do abuso e propunham outros critérios para sua identificação, que podem ser reduzidos ao desvio de finalidade. Já as teorias mistas sugeririam a combinação de elementos objetivos e subjetivos, ou seja, a caracterização do ato abusivo dependeria da investigação da legitimidade dos motivos que levaram à prática do ato, bem como da constatação do desvio da finalidade em sua execução" (MARIA CAROLINA SILVEIRA BERALDO, O comportamento dos sujeitos processuais, p. 98).

${ }^{409}$ CASTRO FILHO, Abuso do direito no processo civil, p. 29.

${ }^{410}$ Jorge Americano, Do abuso do direito no exercicio da demanda, p. 29.

411 Ao enfrentar o tema em sua dissertação de mestrado, HELENA ABDO adere à teoria mista para configuração do abuso do processo, afirmando que "o elemento subjetivo é, em princípio, necessário à configuração do abuso do processo" (Fundamentos sistemáticos, p. 134). Mas, talvez seja justamente pela dificuldade de aplicação da teoria do abuso do processo caso fosse necessário demonstrar o elemento subjetivo que a autora, quando da publicação de sua obra, alterou seu entendimento, passando a defender que
} 
Nesse sentido, interessantes são as conclusões de MARIA CAROLINA BERALDO ao analisar a necessidade de averiguação do dolo ou da culpa para configurar a má-fé processual, raciocínio que se estende à configuração do abuso do processo. Segundo a autora, "o dolo processual é aferido objetivamente a partir da exteriorização do ato processual, das circunstâncias em que praticado, e não da aferição da psique do agente."412, e, nesses casos, altera-se a inversão do ônus da prova, passando a ser do agente abusivo o ônus de demonstrar que não atuou com desvio de finalidade.

E tais conclusões se coadunam com a presunção de que as partes atuam em conformidade com a boa-fé a que se fez referência em item anterior (item 5.1. supra). É certo que a presunção existe, mas ela pode ser quebrada a qualquer momento se, pela análise das circunstâncias do caso concreto, o juiz entender que houve prática de ato processual que desvirtue sua finalidade original, que desvirtue o fim último do processo, que é trazer a pacificação social aos conflitos por meio de decisões justas.

A partir daí, transfere-se o ônus de comprovar que não houve dolo processual ao litigante que, em princípio, agiu de má-fé, abusando de uma posição jurídica subjetiva $^{413}$. E isso permite que a análise do abuso do processo se faça com base em elementos objetivos, apenas, motivo pelo qual deixamos de ressaltar o dolo ou culpa como requisito necessário à configuração do abuso do processo.

o abuso do processo seja configurado tal como o legislador brasileiro determinou a configuração do abuso de direito, ou seja, sem a necessidade de perquirição do elemento subjetivo (art. 187 do Código Civil). Ressalta a autora que, não obstante a desnecessidade de demonstrar o dolo ou a culpa, é comum que eles estejam presentes, o que serve de reforço à configuração do abuso: "Acredita-se que a posição mais coerente a ser adotada relativamente ao abuso do processo seja, realmente, aquela que se harmozina com a clara previsão contida no art. 187 do CC. Assim, uma vez que se chegou à conclusão de que o ordenamento brasileiro optou pelo critério objetivo-finalístico no âmbito do abuso de direito, o mesmo critério deverá ser adotado para o abuso cometido no âmbito de uma relação jurídica processual. A opção pelo critério objetivo não corresponde, todavia, à afirmação de que a conduta processual abusiva deve ser totalmente desprovida de qualquer caráter doloso ou culposo. Ou seja, eventual dolo ou culpa pode ou não estar presente no ato cometido por qualquer dois sujeitos processuais, sem que isso retire da conduta o seu caráter abusivo. O que a lei dispensa é a perquirição do elemento subjetivo no caso concreto" (HELENA NAJJAR ABDO, O abuso do processo, pp.120-121). No mesmo sentido desse segundo posicionameno, destaca-se CASTRO FILHO, Abuso do direito no processo civil, p. 28; MARIO MASCIOTRA, La conducta procesal de las partes, p. 65.

412 O comportamento dos sujeitos processuais, pp. 93-94.

413 MARIA CAROLINA BERALDO também defende a existência de uma pressuposição da boa-fé no comportamento das partes. E ainda, entende não ser contraditório com essa presunção o fato de se inverter o ônus processual quando as circunstâncias indiquem rompimento com o dever de boa-fé: “ Não se nega, com tais afirmações, que não haja presunção de probidade e honestidade das partes em sua atuação processual. Ao contrário, como afirmou Luso Soares, a boa-fé é elemento constitutivo da própria substância da atividade dos litigantes, vale dizer, está ligada ao conceito e finalidade do processo próprio. (...) Ocorre que a partir da análise objetiva da prática de determinados atos processuais pode-se perfeitamente desconstituir a presunção inicial de boa-fé ante a constatação da violação de qualquer dos deveres processuais previstos no ordenamento. Ao litigante caberá reconstruí-la. (O comportamento dos sujeitos processuais, p. 95). 
Dessa feita, uma vez preenchidos os requisitos destacados, configura-se o abuso do processo, o qual enseja sanções diversas. Em verdade, diz-se que em razão de tanto os interesses das partes quanto do Estado poderem ser prejudicados pela prática de atos processuais abusivos, as consequências processuais são mais amplas quando comparadas com as previstas pelo sistema de Direito Civil ${ }^{414}$.

Michele TARUFFo, ao analisar o tema do abuso do processo em diferentes ordenamentos jurídicos, constata alguns tipos diferentes de sanções, que são divididos em três grandes grupos: (i) pagamentos monetários, tais como (a) as indenizações, as quais dependem da comprovação do dano à parte a ser ressarcida; (b) a distribuição de custas, o que nem sempre é efetivo porque o vencido é quem costuma abusar do processo e este geralmente já está incumbido do pagamento das custas; (c) e multas e penalidades; (ii) outras sações, como nulidade, anulabilidade, não receptividade, preclusão, ilegalidade, rejeição, negação, etc. e (iii) sanções destinadas ao advogado, as chamadas sanções disciplinares $^{415}$.

No Brasil, existem igualmente sanções que podem ser agrupadas nessas categorias, mas existem outras que não se enquadram a nenhuma delas, como a possibilidade de antecipação dos efeitos da tutela diante do abuso do direito de defesa (art. 273, inc. II, do CPC). Em razão disso, optamos por fazer referência às conclusões de ANDRÉ SANTORO CARRADITA, que, sem agrupar as consequências em diferentes classificações, optou por elencar uma a uma, em minuscioso e completo trabalho. A nós, não é interessante aprofundar o estudo de cada uma das consequências, mas apenas elencálas para que, com base nessa indicação, seja possível comparar as consequências da adoção de comportamentos contraditórios com relação ao universo mais amplo de abusos do processo.

Assim, são consequências do abuso do processo identificadas em nosso sistema: (i) a reparação de perdas e danos (arts. 16 e 18; 69; 133, 144, II, 147; 150 e 153 do

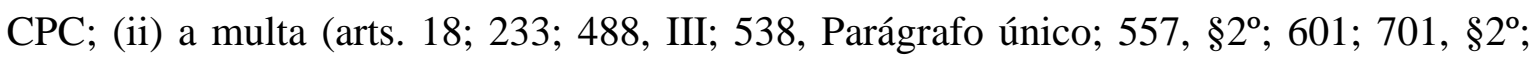
740, Parágrafo único; e 746, $\S 3^{\circ}$, do CPC); (iii) o pagamento de multa como pressuposto objetivo de admissibilidade de recursos posteriores (arts. 538, Parágrafo único; e 557, § $2^{\circ}$, do CPC); (iv) a obrigação de arcar com o custo do processo (arts. 18; 22; 29; 31; 113, § $1^{\text {o }}$; e 267, $\S 3^{\circ}$, do CPC); (v) a antecipação de tutela (art. 273, II do CPC); (vi) a prolação de

\footnotetext{
${ }^{414}$ HUMBERTO THEODORO JÚNIOR, Abuso de direito processual no ordenamento jurídico brasileiro, p. 117.

${ }^{415}$ MiCHELE TARUFFO, Abuso de direitos processuais, pp. 175-181.
} 
sentença que obste o objetivo das partes de praticar ato simulado ou de conseguir fim ilícito pela via processual (art. 129 do CPC); (vii) o cabimento da ação rescisória (art. 485, inc. III do $\mathrm{CPC})^{416}$; (viii) a relativização da coisa julgada; (ix) a nulidade processual e (xi) a remoção do inventariante (art. 995, inc. II e VI do CPC) $)^{417}$.

\subsubsection{Venire: abuso do processo pelo rompimento da boa-fé}

O estudo sob a ótica do abuso do processo permite definir a boa-fé como critério capaz de demonstrar o desvio de finalidade necessário à configuração do abuso. Afinal, descumprindo-se o dever de atuação em conformidade com a boa-fé, torna-se presente o desvio da finalidade do ato. $\mathrm{O}$ desrespeito à boa-fé é uma das formas de se identificar o desvio de finalidade, não sendo à toa que muitos autores identificam na positivação do dever dos sujeitos processuais de se comportar conforme a boa-fé a base jurídica para a aplicação do abuso do processo $^{418}$.

Entendendo-se, como faz a teoria finalista, o desvio de finalidade como o elemento principal necessário à configuração do abuso de direito, uma vez verificada a ausência da boa-fé objetiva na conduta, demonstra-se o desvio e, por consequência, reconhece-se o abuso. Mas, mesmo para aqueles que entendem necessária a presença de dolo ou culpa para verificar a presença do abuso do processo, a boa-fé objetiva não deixa de servir de base para aferição do desvio de finalidade.

HELENA ABDO revela aceitar a inobservância da lealdade processual como critério suficiente para configuração do abuso do processo, dada a estreita ligação entre os deveres de agir com lealdade e veracidade e a própria finalidade do processo $^{419}$ : ausente o compromisso com tais deveres, é automático o desvirtuamento do processo no que diz

\footnotetext{
${ }^{416}$ Trata-se do cabimento da rescisória quando a sentença "resultar de dolo da parte vencedora em detrimento da parte vencida, ou em colusão entre as partes, a fim de fraudar a lei". ANDRÉ SANTORO CARRADITA cita caso bastante interessante em que a rescisória foi fundamentada e julgada procedente com base no art. 485, III, do CPC, caso em que houve abuso do processo: houve acordo entre as partes, no qual uma se comprometeu a desistir da demana se a outra doasse um bem a terceiro. Não obstante a efetivação da doação, não houve a desistência. $\mathrm{O}$ doador deixou de apresentar contestação, confiando no acordo, e, diante da sua revelia, a ação foi julgada procedente. Foi ajuizada rescisória e, assim, rescindida a sentença fundada em abuso do processo. (Abuso de situações jurídicas processuais no Código de Processo Civil, pp. 349).

${ }^{417}$ ANDRÉ SANTORO CARRADITA, Abuso de situações jurídicas processuais no Código de Processo Civil, pp. 270-271.

${ }^{418}$ ANGel LANDONi Sosa, El abuso de los derechos procesales, p. 131; EdUARDo OteIZA, Abusos de los derechos procesales en América Latina, p. 12.

${ }^{419}$ HelenA NAJJAR ABDo, $O$ abuso do processo, p. 144.
} 
respeito às suas finalidades, que certamente envolvem "possibilitar ao juiz a decisão justa e verdadeira, restabelecer a paz jurídica entre as partes e assim defender os interesses maiores da sociedade" ${ }^{, 420}$.

Disso se conclui que, assim como ocorre no campo do Direito Civil, no âmbito processual a boa-fé objetiva e o abuso não são figuras excludentes, mas complementares: a boa-fé serve como critério objetivo para configuração do desvio de finalidade, ao passo que o abuso do processo é uma das modalidades de comportamento em que a inobservância da boa-fé se manifesta ${ }^{421}$.

E, da mesma maneira que se constatou sobre a relação entre a boa-fé objetiva e o abuso do direito no item 3.2.2. supra, o venire contra factum proprium processual é uma espécie de abuso do processo por violação à boa-fét ${ }^{422}$. Não são figuras absolutamente coincidentes porque o abuso do processo é mais amplo, pode se dar não só com base na ruptura da confiança pelo exercício de condutas processuais contraditórias e nem só com base na inobservância da boa-fé, do que se conclui que o abuso do processo é gênero, do qual o venire processual é espécie ${ }^{423}$.

Essa afirmação é corroborada pelo fato de que também no venire processual requer-se a prática de situações jurídicas processuais, as quais lhe conferem a aparência de legalidade, tornando-se ilegal pela contradição afrontadora da boa-fé, ou seja, pelo desvio de finalidade.

\footnotetext{
${ }^{420}$ CARlos AlBerto Alvaro, Do formalismo no processo civil, p. 116.

${ }^{421}$ No mesmo sentido, destaca-se: "É fácil perceber que o princípio da atuação de acordo com a boa fé é a fonte normativa da proibição do exercício inadmissível de posições jurídicas processuais, que podem ser reunidas sob a rubrica do 'abuso do direito' processual (desrespeito à boa-fé objetiva), que se caracteriza independentemente de a atuação do sujeito processual estar fundada em má fé" (FrEDIE DIDIER JR., Fundamentos do Princípio da Cooperação no Direito Processual Civil Português, p. 85). E ainda: LeIDE SANTOS, A boa-fé objetiva no processo civil, p. 184;

422 "O comportamento contraditório de uma parte pode ser considerado como abusivo quando a parte em um procedimento contradiz seu próprio comportamento extrajudicial ou um ato extrajudicial, como, por exemplo, um ajuste (...). Todavia, um contraditório comportamento abusivo pode ter lugar mesmo dentro do mesmo procedimento" (MICHELE TARUFFO, Abuso de direitos processuais, p. 169).

423 "O comportamento incompatível (a segunda conduta) também deve se revelar aparentemente lícito, porque se fosse ilícito sua vedação decorreria de outras normas. Ou seja, a conduta incompatível não corresponde à violação de um dever. Essa constatação coloca a proibição dentro da idéia de abuso de direito, ou, de forma mais ampla, no abuso de posições jurídicas de vantagem (direitos subjetivos e poderes jurídicos), que nada mais é que o uso indevido das alternativas de conduta existentes para o agente" (Antonio do PASso CABRAL, Nulidades no processo moderno, p. 320).
} 


\subsection{Litigância de má fé, ilícito processual, improbilidade e atos atentatórios à dignidade da justiça}

Se antes predominou a visão do processo como um jogo sem valores a serem protegidos, atualmente o repúdio a essa perspectiva é tão grande, que não faltam referências doutrinárias a institutos processuais com nomes distintos destinados à reprimenda de comportamentos indesejados, comportamentos contrários a valores como a boa-fé e a cooperação. Além do abuso do processo supra analisado, destaca-se a litigância de má-fé, a improbidade, o ilícito processual e os atos atentatórios à dignidade da justiça.

Como vimos, a vedação a comportamentos contraditórios é uma modalidade de abuso do processo. Seria ela também uma espécie de uma dessas outras figuras, diante da nítida coincidência de escopos de reprimir condutas indesejadas ao processo? Para responder a essa pergunta - que se faz fundamental para concluirmos quanto às diferentes consequências da adoção de comportamentos contraditórios no processo - é preciso averiguar se essas figuras todas são, em si, dotadas de autonomia.

A improbidade processual nada mais é do que a conduta contrária ao princípio da probidade, que, para muitos autores, abrange todas as ideias de boa-fé, lealdade e cooperação incidentes sobre o processo ${ }^{424}$. A probidade, portanto, é um conceito amplo e genérico utilizado por alguns autores para reunir todos os valores desejados e relativos às condutas dos sujeitos processuais.

Para não manusearmos um conceito de tão elevado grau de abstratação, entendemos que a boa-fé e a cooperação são valores mais tangíveis e capazes de explicar com mais precisão as expectativas que o venire visa a tutelar. Entretanto, se o entendimento é o de que a probidade condensa todas essas ideias, o venire não deixa de atuar em serviço dela.

\footnotetext{
${ }^{424}$ Nesse sentido MARIA CAROLINA BERALDO afirma que "Abuso do processo, improbidade processual, litigância de má-fé, fraude processual, ilícito processual: não obstante serem inúmeros os termos usados quase que indistintamente para definir as más práticas de atos processuais, é certo que toda a filosofia do comportamento processual gira em torno de um preceito comum e de natureza eminentemente ética, que traduz verdadeiro dever-síntese comportamental, que abrange boa-fé e lealdade: a probidade" ( $O$ comportamento dos sujeitos processuais, p. 87). No mesmo sentido, $c f$. FABIO MILMAN, Improbidade processual, pp. 33-36. ALCIDES DE MENDONÇA LIMA também confere amplo significado ao conceito de probidade, aplicando-o a todos os sujeitos processuais, cf. O princípio da probidade no Código de Processo Civil Brasileiro, pp. 20 e seguintes; cf., ainda, ANDRÉ PAGANI DE SOUZA, Vedação das decisões-surpresa no processo civil, p. 55.
} 
A noção de ilícito processual varia entre aqueles que entendem se tratar de violação frontal à lei $^{425}$, ou se abarca também as hipóteses de violação a princípios vigentes $^{426}$. Como o venire corresponde a um abuso do processo e que, portanto, tem aparência de legalidade e se torna abusivo somente diante do exercício de situações jurídicas processuais contrárias ao princípio da boa-fé, ele será um ato ilícito somente para a segunda corrente, na medida em que afronta princípios do sistema jurídico.

Descabe a nós aprofundar a discussão, pela ausência de repercussões práticas que isso traria ao nosso objeto de estudo, mas, para que não pequemos pela omissão, entendemos que o venire, como abuso do direito que é, é uma modalidade de ilícito, o qual se configura não pela simples violação da lei (ilícito em sentido estrito), mas a partir da análise valorativa quanto ao desrespeito a um princípio, integrando, assim, a categoria de ilícitos em sentido amplo.

Resta-nos, assim, enfrentear o tema da litigância de má-fé.

O estudo da litigância de má-fé no ordenamento brasileiro esbarra em divergências doutrinárias constantes, principalmente quanto ao fato de (i) para ser considerado litigante de má-fé, ser necessário ou não identificar no agente o elemento subjetivo de dolo ou culpa; (ii) o rol de condutas configuradoras da litigância de má-fé ser taxativo ou não; e (iii) se é preciso dano para qualificar o comportamento como de litigância de má-fé. E, com base nas conclusões quanto a esses pontos, é possível enfrentar a questão referente (iv) à coincidência ou não da litigância de má-fé com o abuso do processo.

Sobre o primeiro tema, nota-se que o mesmo embate doutrinário relativo ao elemento subjetivo para configuração do abuso do processo se faz presente quanto à caracterização da litigância de má-fé.

Ocorre que, no campo da litigância de má-fé, predomina o entendimento de que é preciso dolo ou culpa para que ela reste configurada. Há vozes em sentido contrário $^{427}$, mas, em termos genéricos, entende-se que o litigante somente pode ser considerado de má-fé se comprovada a intenção de agir em desconformidade com o

\footnotetext{
${ }^{425}$ Helena ABDo, $O$ abuso do processo, p. 104.

${ }^{426}$ MARIA CAROLINA BERALDO, O comportamento dos sujeitos processuais, pp. 100-101.

427 MARIA CAROLINA BERAldo, O comportamento dos sujeitos processuais, pp. 93-94. FABIO MILMAN afirma: "Inclinamo-nos, pois, pela adoção, sempre preferível em matéria de punição ao improbus litigator, da teoria objetiva, em que pese a inclinação da jurisprudência em verificar, antes da aplicação de qualquer sanção, a existência do dolo na má condução processual'(,Improbidade processual, p. 49).
} 
direito, de prejudicar outrem. Essa é a posição da maior parte da doutrina ${ }^{428}$ e da jurisprudência $^{429}$.

Nós, todavia, concordamos com a parcela da doutrina que, ainda que entenda necessária a presença do elemento subjetivo, defende que ele seja aferido por meio da análise do contexto objetivo dos autos e do comportamento da parte. Se esse contexto é suficiente para dele se extrair a má-fé subjetiva, cria-se uma presunção nesse sentido e caberá ao litigante cuja conduta está sendo reprovada afastar essa presunção ${ }^{430}$.

Quanto à taxatividade ou não do rol elencado no art. 17 do Código de Processo Civil, as poucas referências encontradas que tratam diretamente do tema apontam para uma resposta afirmativa, ou seja, sustentam que compõem o conceito de litigância de má-fé a prática de uma das condutas descritas no referido artigo ${ }^{431}$.

Assim, para ser considerado litigante de má-fé é preciso deduzir pretensão ou defesa contra texto expresso de lei ou fato incontroverso (inciso I), alterar a verdade dos fatos (inciso II), usar do processo para conseguir objetivo ilegal (inciso III), opor resistência injustificada ao andamento do processo (inciso IV), proceder de modo temerário em qualquer incidente ou ato processual (inciso V), provocar incidentes manifestamente infundados ou interpor recursos com escopo manifestamente protelatório (inciso VI). Além dessas condutas, aquelas descritas como atos atentatórios à dignidade da

\footnotetext{
${ }^{428}$ PEDRO DE AlBUQUERQUE, Responsabilidade processual por litigância de má-fé, p. 48; CÂNDIDO RANGEL Dinamarco, Instituições de Direito Processual Civil, v. II, p. 272; ANA LÚCIA IUCKER DE OLIVEIRA, Litigância de má-fé, p. 4; RuI StOCO, Abuso de direito e má-fé processual, p. 94; ANNE JoYCe ANGHER, Litigância de má-fé no Processo Civil, p. 95; CELSO IOCOHAMA, Litigância de má-fé e lealdade processual, p. 155; BRUNELA VICENZI, A boa-fé no processo civil, p. 99.

${ }_{429}$ A título ilustrativo, apenas, destaca-se o posicionamento do Superior Tribunal de Justiça, que inclusive deixa de reapreciar o tema da litigância porque, para isso, teria que analisar justamente as provas quanto ao elemento subjetivo, o que é vedado pela Súmula 7 ("A pretensão de simples reexame de prova não enseja recurso especial."): “TRIBUTÁRIO. PROCESSUAL CIVIL. AGRAVO REGIMENTAL NO RECURSO ESPECIAL. LITIGÂNCIA DE MÁ-FÉ. VERIFICAÇÃO EM SEDE ESPECIAL. IMPOSSIBILIDADE. ENUNCIADO SUMULAR 7/STJ. JURISPRUDÊNCIA PACÍFICA. AGRAVO NÃO PROVIDO. 1. 'O reexame do cabimento da aplicação da multa por litigância de má-fé demanda a análise da existência do elemento subjetivo das hipóteses autorizadoras, o que é vedado a esta Corte, pelo óbice da Súmula 07/STJ"” (AgRg no AREsp 105.339/SP, Primeira Turma, Rel. Min. NAPOLEÃO NUNES MAIA FILHO, DJe 17/9/12). Assim, o Superior Tribunal adota posicionamento de que a litigância de má-fé imprescinde da demonstração do dolo.

2. Agravo regimental não provido.

(AgRg no REsp 1228812/RS, Rel. Ministro ARNALDO ESTEVES LIMA, PRIMEIRA TURMA, julgado em 09/04/2013, DJe 19/04/2013)

${ }^{430}$ É o pensamento, v.g., de MARIa CAROLINA Beraldo que já destacamos no item 6.1. supra. PaUla CostA E SILVA, analisando o nosso sistema brasileiro de litigância de má-fé, afirma que o enquadramento do sujeito como litigante prescinde de elemento subjetivo, de modo que "somente a circunstância de esta conduta ser qualificada como litigância de má-fé permite inferir que a pare deve actuar culposamente" (A litigância de má-fé, pp. 314-315), pensamento que se coaduna com nosso posicionamento.

431 ANNE JoYCe ANGHER, Litigância de má-fé no Processo Civil, p. 114; RUI STOCO, Abuso de direito e máfé processual, p. 97.
} 
justiça também integram o rol, porém exigem que se trate de ato praticado no curso de uma execução ou fase de cumprimento de sentença.

Ocorre que muitos autores admitem que há outros comportamentos indesejados aos quais se aplicam as mesmas sanções destinadas ao litigante de má-fé; entretanto, ao invés de fazer inserir no rol expresso da litigância essas situações não taxativas, prefere-se dizer que esses casos compõem a categoria do abuso do direito ${ }^{432}$. Dessa forma, entende-se que litigância de má-fé propriamente dita são só as condutas elencadas no artigo 17 do Código de Processo Civil e outros comportamentos indesejados passam a ser chamados de abuso do processo.

Sobre o dano e a necessidade de ele ser identificado para configurar a litigância de má-fé, é frequente a opinião de que sempre a litigância de má-fé acarreta danos ao processo, ainda que se trate de danos morais suportados pelo adversário. FABIO MILMAN afirma que o "dano moral é sempre presumido para aquele que, à sua frente, encontrar adversário a litigar de má-fé. Estar em juízo é estar sob impacto emocional, diante das incertezas, temores, alargada insatisfação, no tempo, de direito que entenda ser credor" ${ }^{, 433}$, sentimentos que só se agravam diante da litigância em face de um sujeito que age de máfé.

Outros autores não chamam esse dano inexoravelmente decorrente da litigância da má-fé de dano moral, e sim de agravamento do dano marginal provocado pelo processo. Nesse sentido, ANDRÉ LUIS CARRADITA afirma que "se o juízo exigisse a comprovação das perdas e danos decorrentes da demora que a conduta ímproba causou na entrega da prestação jurisdicional, seria bastante rara a incidência do art. 18 do CPC", de modo que se dispensa a parte de comprovar esse dano e o juiz deve desde logo liquidá-los com base na equidade $^{434}$. Para esses autores, portanto, a litigância envolve sempre como elemento caracterizador um dano, ainda que denominado de diferentes maneiras.

E, para os que assim admitem, a existência de um dano presumido gera o direito a uma indenização (igualmente presumida) de até $20 \%$ prevista pelo art. 18 do

\footnotetext{
${ }^{432}$ Assim sistematiza, por exemplo, CÂNDIDO RANGEL DINAMARCO: "Em resumo, têm-se por contrárias ao princípio da boa-fé e lealdade (a) as condutas tipificadas como litigância de má-fé; (b) as definidas como atos atentatórios à jurisdição ou à dignidade da Justiça e (c) as que, embora não tipificadas, caracterizem abuso de direito no processo.” (Instituições de Direito Processual Civil, v.II, p. 267).

${ }^{433}$ Improbidade processual, p. 231. O mesmo é afirmado por ANNE JOYCE ANGHER, Litigância de má-fé no Processo Civil, pp. 104-105; CELSO IOCOHAMA, Litigância de má-fé e lealdade processual, p. 229; ANA LÚCIA IUCKER DE OLIVEIRA, Litigância de má-fé, p. 80.

${ }^{434}$ Abuso de situações jurídicas processuais no Código de Processo Civil, p. 279.
} 
CPC, além da multa, que não tem caráter reparatório e sim sancionador. Em caso de os danos superarem apenas esses presumidamente existentes, eles devem ser apurados em liquidação por arbitramento ${ }^{435}$.

Essa, todavia, não é a posição majoritária da jurisprudência, que entende que, para que se fale em indenização, faz-se necessária a demonstração de efetivo prejuízo, e não a mera presunção de sua ocorrência ${ }^{436}$. $O$ entendimento de nossa jurisprudência se coaduna com a doutrina que afirma que a litigância de má-fé, para ser configurada, independe de dano, elemento necessário apenas a ensejar a responsabilidade civil decorrente de prejuízos causados por condutas processuais ${ }^{437}$.

Com base nessas breves constatações quanto ao tema da litigância de má-fé, é possível estabelecer sua relação com o abuso do processo.

435 ANA LÚCIA IUCKER DE OLIVEIRA bem sintetiza nossa exposição: “O artigo 18, então, pode ser interpretado da seguinte forma: se o juiz afere a conduta ímproba e a parte prejudicada não alega prejuízos materiais, a indenização só é devida pelos danos morais, pois o litigante foi atingido no seu direito de ter um processo pautado pela probidade, e ainda, a indenização tem caráter nitidamente sancionador; pode, então, o juiz estabelecer desde logo a sanção em até $21 \%$ do valor da causa: $1 \%$ a título de multa e $20 \%$ a título de indenização. Do mesmo modo, se o prejudicado comprova prejuízos em valor a menor que o percentual mencionado, o juiz pode condenar de imediato até àquele valor, além da multa. Porém, se a parte demonstra que os prejuízos montam a quantia superior, o juiz condena por litigância de má-fé, arbitra o valor da multa e remete a apuração do quantum debeatur da indenização à liquidação." (Litigância de má-fé, p. 80).

${ }^{436}$ Nesse sentido é o posicionamento dominante do Superior Tribunal de Justiça, o qual se ilustra por meio do seguinte julgado: RECURSO ESPECIAL. PROCESSUAL CIVIL. RECURSOS ESPECIAIS INTERPOSTOS PELA OAB/SP E PELO AUTOR DA AÇÃO POSSESSÓRIA E SEUS PATRONOS. LITIGÂNCIA DE MÁ-FÉ. DANO PROCESSUAL. INDENIZAÇÃO. NÃO DEMONSTRAÇÃO DO PREJUÍZO. MULTA. CONDENAÇÃO SOLIDÁRIA DO PROMOVENTE E SEUS ADVOGADOS. IMPOSSIBILIDADE. NECESSIDADE DE AÇÃO PRÓPRIA. ACOLHIMENTO DAS TESES RECURSAIS. 1. Não há como, na via estreita do recurso especial, afastar a configuração da litigância de máfé (CPC, arts. 17 e 18), reconhecida nas instâncias ordinárias com base na interpretação do acervo fáticoprobatório dos autos. Incidência da Súmula 7/STJ. 2. É permitido ao Juiz decretar de ofício a litigância de má-fé, podendo condenar o litigante faltoso a pagar multa e a indenizar a parte contrária pelos prejuízos causados (CPC, art. 18, caput e $\S 2^{\circ}$ ). 3. Na fixação da indenização, considerada sua natureza reparatória, é necessária a demonstração do prejuízo efetivamente causado à parte adversa, em razão da conduta lesiva praticada no âmbito do processo, diferentemente do que ocorre com a multa, para a qual basta a caracterização da conduta dolosa. 4. Reconhecida a litigância de má-fé nas instâncias ordinárias, sem demonstração do prejuízo causado à ré, mostra-se cabível a aplicação ao autor da multa não excedente a $1 \%$ sobre o valor da causa, afastando-se a indenização do art. 18 do CPC. 5. Os embargos declaratórios opostos com o intuito de prequestionamento não podem ser considerados procrastinatórios (Súmula 98/STJ). 6. Em caso de litigância de má-fé (CPC, arts. 17 e 18), descabe a condenação solidária da parte faltosa e de seus procuradores. A conduta processual do patrono da parte é disciplinada pelos arts. 14 do CPC e 32 do Estatuto da Advocacia e da Ordem dos Advogados do Brasil - EAOAB (Lei 8.906/94), de maneira que os danos processuais porventura causados pelo advogado, por dolo ou culpa grave, deverão ser aferidos em ação própria. 7. Recurso especial da OAB/SP provido. 8. Recurso especial do autor e seus patronos parcialmente provido. (REsp 1331660/SP, Rel. Ministro RAUL ARAÚJO, QUARTA TURMA, julgado em 17/12/2013, DJe 11/04/2014 - grifou-se). Nesse sentido é a interpretação de PAULA CoSTA E SILVA com relação ao ordenameno português, $c f$. A litigância de má-fé pp. 524 e seguintes.

${ }^{437}$ Nesse sentido afirma MENEZES CoRdEIRO, Litigância de má-fé, abuso do direito de ação e culpa "in agendo", p. 56. 
Como já ressaltado, há quem entenda que litigância de má-fé e abuso do processo não se confundem. As principais diferenças apontadas são: (i) a litigância está taxativamente prevista; (ii) sua configuração requer um elemento subjetivo, o que não é a realidade da configuração do abuso do processo; e ainda se aponta, com menos frequência, (iii) o fato de o abuso do processo tutelar danos também de interesse privado, ao passo que a litigância visa a reprimir apenas condutas contrárias aos interesses públicos do Processo $^{438}$.

Porém, nossas premissas fazem com que não seja possível conclusão outra senão a de que a litigância insere-se no âmbito do abuso do processo, nada mais sendo do que hipóteses específicas e positivadas de abuso do processo.

Afinal, a leitura de cada uma das condutas descritas no art. 17 do Código de Processo Civil revela que nele estão indicados comportamentos inicialmente lícitos, ou seja, que aparentam legalidade, mas que se tornam ilícitos por distanciarem-se dos fins a que destinados, subsumindo-se aos requisitos para a configuração do abuso do processo. A diferença estaria na necessária demonstração do elemento subjetivo para que se possa falar em litigância de má-fé, mas, para nós, esse requisito não está previsto em lei e não faz sentido que ele seja exigido por tornar inócua a utilização do instituto, defendendo-se a aferição da ruptura da boa-fé objetiva, apenas. E, com relação aos danos, entendemos que tanto uma quanto outra figura visam a proteger o interesse público, bem como indenizar eventuais perdas que a parte adversa venha a sofrer.

Dessa forma, concordamos com a opinião segundo a qual "a análise de cada uma das previsões do art. 17 do CPC permite concluir que todas elas constituem casos de abuso do processo "439. A litigância de má-fé, portanto, consiste em casos positivados pelo

\footnotetext{
438 Assim define PEDRO DE ALBUQUERQUE referindo-se à realidade do ordenamento português, que, por sua vez, é bastante semelhante ao nosso nesse ponto: "O abuso de direito tem natureza objectiva. Ele é independente da consciência de quem comete o apelidado acto abusivo, bastando o comportamento em si mesmo. Dito de outro maneira: o abuso de direito não está dependente nem da existência de culpa do agente nem de qualquer outro elemento subjectivo, embora a presença ou ausência desses elementos possa contribuir para a definição das consequências do abuso. Diversamente, a litigância de má-fé depende, como se viu, da existência da culpa grave ou de dolo. O elemento subjectivo é, pois, um pressuposto constitutivo da figura. Além disso, o abuso de direito pressupõe a existência de danos, devendo eles ser considerados na totalidade. Não sucede o mesmo com a litigância de má-fé. A simples obstrução da justiça e a violação de deveres processuais é suficiente para a condenação da parte. Os danos sofridos poderão apenas ser contemplados de forma parcial" (Responsabilidade processual, pp. 92-93).

${ }^{439}$ HeLENA ABDo, Abuso do processo, p. 156. Da mesma maneira, entendendo que litigância é uma modalidade de abuso, afirmam ANNE JoYCE ANGHER, Litigância de má-fé no Processo Civil, p. 79; ANA LÚCIA IUCKER DE OLIVEIRA, Litigância de má-fé, p. 34.
} 
legislador de abuso do processo, que, por sua vez, é figura mais ampla - aplicável inclusive, ao órgão julgador ${ }^{440}$, o que não é realidade para a litigância de má-fé ${ }^{441}$.

Sendo o venire contra factum proprium uma forma de abuso do processo, e considerando que a litigância de má-fé consiste em casos positivados de abuso, ao venire aplicam-se também as sanções previstas para a litigância de má-fé, conforme se esclarecerá no item 8.5.2. infra.

Por fim, os atos atentatórios à dignidade da justiça são classificados como integrantes do conceito de litigância de má-fé, porém com a especificidade de se referirem a atos praticados no curso de uma execução ou cumprimento de sentença ${ }^{442}$. Assim, o que concluimos para a litigância de má-fé valerá para os atos atentatórios à dignidade da justiça.

\subsection{Valoração judicial da conduta das partes}

A valoração judicial da conduta das partes é um fenômeno ainda pouco estudado no Brasil, tema de maior desenvolvimento doutrinário nos países em que existem menções expressas a esse mecanismo de convencimento do magistrado em suas respectivas legislações processuais ${ }^{443}$.

\footnotetext{
${ }^{440}$ HELENA ABDO, Abuso do processo, pp. 183-188. Segundo a autora, o abuso do processo do órgão julgador se traduz pelo abuso de poder, já que, como vimos, suas situações jurídico processuais são essencialmente os poderes-deveres. Assim, abusando dessa situação por meio do desvio de finalidade, pratica-se um abuso de poder.

${ }^{441}$ A litigância é destinada apenas às partes e aos terceiros, $c f$. ANNE JOYCE ANGHER, Litigância de má-fé no Processo Civil, p. 15; ANA LÚCIA IUCKER DE OLIVEIRA, Litigância de má-fé, p. 70.

${ }^{442}$ FABIO MILMAN, Improbidade processual, p. 36; MARIA CAROLINA SILVEIRA BERALDO, O comportamento dos sujeitos processuais, p. 92.

${ }^{443}$ É o que preceitua o artigo 116 do Codice di Procedura Civile: "Il giudice deve valutare le prove secondo il suo prudente apprezzamento, salvo che la legge disponga altrimenti. Il giudice puo' desumere argomenti di prova dalle risposte che le parti gli danno a norma dell'articolo seguente, dal loro rifiuto ingiustificato a consentire le ispezioni che egli ha ordinate e, in generale, dal contegno delle parti stesse nel processo" (grifou-se).

No art. 189 do Código General del Proceso uruguaio, tem-se que: "189.3 Si quien debiera prestar colaboración fuera una de las partes y se negara injustificadamente a suministrarla, el tribunal le intimará a que la preste. Si a pesar de ello se persistiere en la resistencia, el tribunal dispondrá se deje sin efecto la diligencia, debiéndose interpretar la negativa a colaborar en la prueba como una confirmación de la exactitud de las afirmaciones de la parte contraria respecto del hecho que se quiere probar salvo prueba en contrario." (grifou-se)

$\mathrm{Na}$ Argentina, o artigo 163, inciso $5^{\circ}$ do Código Procesal Civil y Comercial de la Nación estabelece, em sua parte final, que "La conducta observada por las partes durante la sustanciación del proceso podrá constituir
} 
Não obstante, é comum se afirmar que valorar a conduta das partes é algo intrínseco ao julgador ${ }^{444}$, o que nem sempre se dá de maneira transparente no processo. Por isso, faz-se fundamental melhor compreender esse fenômeno, identificá-lo para que assim possam ser medidas suas consequências, bem como para que se possar depreender a racionalidade do pensamento do julgador ao se utilizar da valoração da conduta das partes.

E isso porque, como bem esclarece GIUSEPPE INGRAO, a valoração da conduta processual é mecanismo intelectual racional, uma vez que fundado nas regras de experiência, as quais proporcionam soluções previsíveis às partes ${ }^{445}$. Tanto isso é verdade que a própria legislação se utiliza dessa racionalidade, como veremos a seguir.

Na definição de JOAN PICÓ I JUNOY, o comportamento de uma parte pode servir de fonte de indícios aptos a fundamentar uma presunção, a partir da qual esse comportamento adquire um valor probatório ${ }^{446}$. A valoração judicial da conduta das partes, portanto, é o fenômeno pelo qual é construída uma presunção que tem por base um comportamento processual da parte, o que contribui para a formação do convencimento do $\operatorname{magistrado}^{447}$.

un elemento de convicción corroborante de las pruebas, para juzgar la procedencia de las respectivas pretensiones."

${ }^{444}$ MIRYAM FAURE afirma que "El juez valora conductas sempre. Es de la esencia de su función hacerlo y no le está permitido huir de este deber" (La valoración judicial de la conducta en juicio, p. 26). No mesmo sentido são as palavras de MARÍA TEPSICH, ao afirmar que "aunque no se exprese en su dictamen, es un procedo natural en la mente del hombre-juez que, independientemente de su objetividad y visión juzgadora, valora, aun en forma inconsciente, el comportamiento que las partes tuvieron en el proceso a la hora de fallar, y como consecuencia, inelutable, de la valoración de la prueba en función de las reglas de la sana crítica." (Valor vinculante de la conducta procesal de las partes en el proceso civil, pp. 298-299).

${ }^{445}$ La valutazione del comportamento delle parti nel processo tributário, p. 56.

${ }^{446}$ JOAN PICÓ I JUNOY, El principio de la buena fe procesal, pp. 313-314. Para FERNANDO HeÑIN: "Se la pueda conceptuar como la posibilidad que tiene el juzgador de extraer argumentos o indicios del conjunto de comportamientos activos y omisivos desplegados por las partes durante la tramitación del proceso, siendo útil especialmente en los casos en que las pruebas producidas son insuficientes para que el mismo pueda reconstruir con certeza los hechos de la causa" (Valoración judicial de la conduta procesal, p. 61). No mesmo sentido, $c f$. GIUSEPPE INGRAO, La valutazione del comportamento delle parti nel processo tributario, pp. 60-61.

${ }^{447}$ Vale apontar que a caracterização da conduta processual da parte como indício não é pacífica na doutrina. Afirma-se que a conduta processual não é prova de fato algum (por não ser elemento destinado a demonstrar qualquer alegação das partes), seja ele primário ou secundário, e, por isso, não pode ser considerada nem como prova, meio de prova, fonte de prova, ou indício. Nesse sentido, $c f$. MARCos PEYRANO, La valoración de la conducta procesal de las partes como derivación del principio de adquisición procesal, pp. 45-55, para quem as condutas processuais se inserem no princípio da aquisição, podendo ser utilizadas pelo juiz como elementos de convicção para corroborar outras provas, ou, na absoluta ausência delas, para auxiliar no julgamento baseado no ônus da prova. DARCI GUIMARÃES RIBEIRO, por sua vez, apresenta interessante raciocínio, com base na premissa de que "deve-se analisar, em primeiro lugar, a estrutura técnica da norma, em cada caso, pois cada comportamento processual recebe, como qualquer fato, uma qualificação jurídica diversa das demais, podendo gerar uma obrigação, um dever ou um ônus" (Provas atípicas, p. 128). Assim, nos casos em que a lei adota o comportamento da parte como suporte fático para um consequência jurídica, ele não tem papel secundário de indício, mas de verdadeira fonte de prova, única e primordial para a demonstração do fato perseguido. 
Dessa maneira, o comportamento processual da parte é apreendido como um fato secundário, um indício sobre o qual, por meio das regras de experiência ${ }^{448}$, surge uma presunção, que pode ser tanto legal quanto judicial. Em outras palavras, a conduta da parte no processo, seja ela omissiva ou comissiva, é um fato percebido diretamente pelo juiz a partir do qual, por dedução lógica baseada na observação do que ordinariamente acontece, infere-se a existência de outro fato, aquele presumido.

Nesse ponto, é preciso fazer uma breve distinção entre as regras de experiência e as presunções. Estas, nas palavras de DinAMARCO, consistem em "um processo racional do intelecto, pelo qual do conhecimento de um fato infere-se com razoável probabilidade a existência de outro ou o estado de uma pessoa ou coisa ${ }^{449}$ ". É, portanto, o resultado desse processo intelectual indutivo, que se afirma na análise de fatos concretos.

As regras de experiência, por sua vez, representam justamente essa "ponte" entre o indício (fato secundário) e a presunção (consequência) e que consistem em normas criadas a partir do senso comum ou no conhecimento pessoal do magistrado, da observação do que reiteradamente acontece dentre as práticas humanas e as quais independem de um caso concreto específico.

Dessa forma, por meio da valoração judicial da conduta da parte admite-se a possibilidade de o juiz tomar o comportamento da parte como um fato secundário conhecido, a partir do qual se inferem argumentos de prova capazes de influenciar o convencimento do juízo quanto ao mérito da causa ${ }^{451}$.

\footnotetext{
${ }^{448}$ EDUARDO CAMBI, A prova civil, p. 363.

449 CÂndido Rangel Dinamarco, Instituições de Direito Processual Civil, v. III, p. 113. No mesmo sentido: "A presunção é um processo mental, não um meio de prova, porque, quando o juiz afirma que 'ocorrido um fato $x$, deve ter ocorrido um fato $y$ ', nada de novo surge no plano material ou concreto (v.g., um documento ou um depoimento), mas exclusivamente em nível intelectual, na mente do magistrado. Pelas presunções, pode-se deduzir do fato provado (conhecido) a existência do fato relevante para o processo; logo, não é um meio de prova, mas apenas uma operação mental pela qual se pode raciocinar a partir do fato demonstrado, por outros meios de prova" (EDUARDO CAMBI, A prova civil, p. 360); “A presunção, portanto, não é meio de prova. É operação mental. É a ilação que se tira de um fato conhecido para provar a existência de outro desconhecido, ou, para compreender as presunções juris e hominis, são induções que a lei ou o juiz tira da reiteração de fatos conhecidos para estabelecer a verdade de fatos desconhecidos" (JONATAS MiLHOMENS, Da presunção da boa-fé no processo civil, pp. 57-58).

${ }^{450}$ FABIo TABOSA, Código de processo civil interpretado, p. 1.057. Sobre o tema, $c f$. ADROALDO FURTADO FABRício, Fatos notórios e máximas de experiência, pp. 431-441. HeITOR VITOR MENDONÇA SiCA bem ilustra essa relação: "Para simplificar esse raciocínio, usando uma figura singela ilustrá-lo, diríamos que a presunção comum é a estrada que liga dois pontos - o fato conhecido e irrelevante (que é o indício) ao fato desconhecido e relevante - sendo o raciocínio do juiz um veículo movido pelas 'regras de experiência' para percorrer esse caminho, de um extremo a outro." (Questões velhas e novas sobre a inversão do ônus da prova, p. 56).

${ }^{451}$ ANDREA PROTO PISANI, Lezioni di diritto processuale civile, p. 431; MisAEL ALBERTO, Valoración judicial de la conducta procesal, p. 129.
} 
Nem sempre a valoração judicial se dá em desfavor do sujeito processual ${ }^{452}$. Pelo contrário, pode lhe ser favorável, sendo possível vislumbrar, v.g., hipótese em que, a despeito de o ônus da prova de determinada alegação ser da parte adversa, o sujeito auxilia na produção da prova, em observância ao princípio da cooperação. Ainda que a prova seja inconclusiva, esse comportamento pode ser valorado positivamente de modo a corroborar o julgamento a ele favorável (vez que a parte contrária não se desincumbiu de seus ônus probatórios), incrementando a fundamentação nesse sentido.

Por se tratar de uma presunção, a valoração tem como premissa a incerteza da existência do fato afirmado ${ }^{453}$, o que significa dizer que, uma vez produzida prova clara e suficiente para gerar o máximo grau de certeza sobre um fato, a valoração é dispensável, ou, no limite, terá um papel bastante reduzido. Sua funcionalidade ganha relevância nos casos em que ausentes elementos probatórios contundentes, hipóteses em que ela servirá de elemento corroborante ou único argumento a justificar a decisão.

Justamente sobre esse tema do papel da valoração, destaca-se que uma das grandes controvérsias reside em saber se as presunções fundadas a partir do comportamento processual da parte podem servir, sozinhas, para a formação do convencimento do juiz, ou se apenas são capazes de reforçar um convencimento já tendente a uma posição com base em provas diretas sobre o thema probandum ${ }^{454}$.

Essa discussão se faz bastante viva na Argentina e na Itália, pelas referências legais destes países à valoração judicial, posicionando-a como apta a trazer um "argumento de prova" (Itália) ou um elemento de convicção "corroborante das provas" (Argentina), o que, para alguns, parece revelar uma intenção do legislador de minorar seu poder de convencimento com relação às demais provas.

Entretanto, apesar de restrições doutrinárias, reconhece-se a possibilidade de a valoração judicial ser indício único a formar a convicção do juiz ${ }^{455}$.

\footnotetext{
452 JORGE PEYRANO, La conducta procesal como elemento de convicción favorable a su autor, pp. 22-23; MIRYAM FAURE, La valoración judicial de la conducta en juicio, pp. 29-31.

${ }^{453}$ INÉS WHITE, La conducta procesal de las partes y los medios de prueba, p. 146; JUAN ALBERTO RAMBALDO, La conducta procesal de las partes como medio de prueba, p. 164; CARINA PAULA SUDILOVSKY, Reflexiones sobre la valoración judicial de la conducta en juicio. Una propuesta académica,

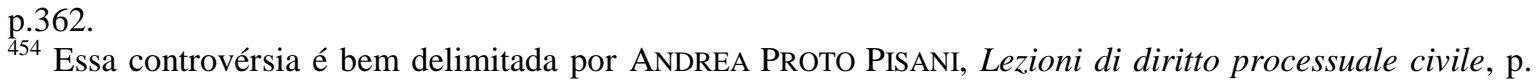
431. Entre nós, defendendo a impossibilidade de o comportamento processual ser único meio de prova, $c f$. ISOLDE FAVARETTO, Comportamento processul das partes como meio de prova, p. 56.

${ }^{455}$ DANIEL FERNANDO ACOSTA, La conducta procesal de las partes como concepto atinente a la prueba, $\mathrm{p}$. 102; FERNANDO HEÑIN, Modernos institutos procesales, p. 183; MisAEL ALBERTO, Valor probatorio de la
} 
A jurisprudência italiana, por exemplo, admite com frequência que "o comportamento processual da parte (...) possa constituir única e suficiente fonte de prova e de convencimento do juiz, e não apenas elemento de avaliação das provas já adquiridas no processo" "456; e isso porque, na prática, há casos em que a valoração da conduta judicial se revela suficiente para formar o convencimento do juiz, como na hipótese da recusa injustificada na exibição de documento, o que torna verídicos os fatos afirmados pelo requerente da exibição, ou no caso de recusa à submissão a perícias genéticas ${ }^{457}$.

Por esse motivo, PROTO PISANI propõe solução intermediária, ao afirmar que uma vez fundado o julgamento apenas na valoração judicial das condutas das partes, o que não deixa de ser possível, qualquer provocação requerendo a produção de uma prova não pode ser desconsiderada, tida como desnecessária, em razão de o fato que se busca conhecer já estar suficiente demonstrado ${ }^{458}$. Ou seja, com base em um convencimento formado apenas por argumentos de prova, não se pode considerar supérflua a produção de outras provas.

Nem toda conduta exercida no curso do processo deve ser objeto de valoração para o magistrado, mas apenas aquelas que correspondam a ônus e a deveres processuais $^{459}$. Afinal, o exercício, ou a inatividade, fundados em um direito, não podem servir de valoração, como ocorre no caso da negativa de testemunhar sobre um fato cuja ciência se obteve mediante sigilo profissional.

Para a grande parte dos estudiosos sobre o tema, retira-se do campo da valoração judicial a conduta da parte praticada fora ou antes do processo, pelo fato de a apreensão desse comportamento como um indício deixar de poder ser feita diretamente pelo juiz, e passar a depender da comprovação da conduta por um meio típico de prova, tal

conducta em juicio, p. 135; INÉs WHITE, La conducta procesal de las partes y los medios de prueba, p. 156; MARIO MASCIOTRA, La conducta procesal de las partes, p. 169.

${ }^{456}$ No original: "il comportamento processuale della parte (...) può constituire unica e sufficiente fonte di prova e di convencimento delle giudice, e non soltanto elemento di valutazione delle prove già acquisite al processo" (Giovanni Novelli e Stefano PetitTi, Codice di procedura civile, p. 638).

${ }^{457}$ FERNANDO HEÑIN, Valoración judicial de la conduta procesal, p. 75-76.

458 "il carattere di probatio inferior degli argomenti di prova rispetto alle prove in senso tecnico va colto, non già in una loro minore efficacia probatoria legislativamente imposta in via di prova legale, bensì unicamente nella inidoneità degli argumenti di prova a giustificare da soli il giudizio di superfluità di cui all'art. 209 (e forse anche ex art. 187, $1^{\circ}$ comma), a fronte della richiesta delle parti di offrire, attraverso una prova in senso tecnico, la prova contraria" (ANDREA PROTO PISANI, Lezioni di diritto processuale civile, p. 432). Para fins de registro, sem que se faça necessário enfrentar com profundidade a controvérsia, GIUSEPPE INGRAO discorda das ideias de PROTO PISANI, afirmando que o autor, em verdade, trata do tema do conflito entre provas, e não da eficácia probatória da conduta das partes, $c f$. La valutazione del comportamento delle parti nel processo tributário, p. 159.

${ }^{459}$ MISAEL ALBERTO, Valor probatorio de la conducta em juicio, p. 131. 
como a prova documental ${ }^{460}$. Diz-se, portanto, que esses são casos não mais de valoração, mas de intercadencia, como manifestação processual da doutrina dos atos próprios ${ }^{461}$, diferenciações que levaremos em conta mais adiante.

Apesar de o ordenamento processual brasileiro não possuir regra expressa quanto à possibilidade de a conduta processual das partes servir como fato secundário a ser valorado, é possível que isso aconteça com base na interpretação conjugada dos artigos 131 e 335 do Código de Processo Civil ${ }^{462}$. Assim, tendo em vista o princípio do livre convencimento, bem como considerando a possibilidade de o magistrado considerar as regras de experiência para formar presunções sobre fatos desconhecidos, é possível que a conduta processual seja valorada de modo a influenciar o resultado do julgamento.

Isso não significa dizer que a expressa previsão legal seria de todo inútil. Certamente, um dipositivo que previsse claramente a valoração da conduta processual das partes como uma possibilidade de formar o convencimento do magistrado representaria uma garantia às partes, assegurando que elas conhecessem com mais precisão as possíveis

\footnotetext{
${ }^{460}$ Em sentido contrário, viabilizando a valoração de condutas praticadas fora da mesma sede processual, destaca-se: "En tal sentido, se debería observar un panorama más amplio en la valoración de la conducta de una parte, no siempre atado a los límites estrechos del proceso en que se la quiere hacer valer; anque con cierta confluencia, en la aplicación, con la doctrina de los propios actos en materia procesal" (DANIEL FERNANDO ACOSTA, La conducta procesal de las partes como concepto atinente a la prueba, p. 105-106) “La conducta normalmente se presentará en forma de 'indicios endoprocesales', conforme al término acuñado por Morello. Pero, en ciertos casos, puede adquirir relevancia probatoria la conduta ajena al proceso. Ejemplo de ello son la conducta preprocesal (sumario prevencional, procesos administrativos) y la tenida en procesos simultáneos o vinculados. También la conducta extraña al proceso, que ingresa al mismo mediante la denuncia de hecho nuevo, medidas para mejor proveer o, incluso, como hecho notorio. El límite está dado por la prohibición del juez de fallar conforme a su conocimiento privado. Quizá, advertido este fenómeno, en lugar de adjetivar como 'procesal' a la conducta, sería más propio decir 'conducta tenida en ocasión del proceso' o conducta 'adecuadamente vinculada' al proceso" (GUILLERMINA CORNERO, Valor probatorio de la conducta procesal, p. 211).

${ }^{461}$ MisAel AlBerto, Valor probatorio de la conducta em juicio, p. 133; FERNANDO HeÑIN, Modernos institutos procesales, p. 193; SILVINA PEREIRA MARQUES sustenta a possibilidade de a valoração de condutas praticadas em outro processo, mas admite que "aunque con cierta confluencia en virtud de la doctrina de los propios actos en materia procesal" (Reflexiones acerca de algunos aspectos de la valoración de la conducta procesal de las partes desplegada en procesos distintos (conexos o no), p. 316).

462 Ao se referir ao art. 116 do Código de Processo Civil Italiano e à possibilidade de se extraírem argumentos de prova do comportamento processual das partes, DINAMARCO afirma que "embora inexista preceito análogo em nosso direito positivo, essa orientação decorre com naturalidade do poder de livre convencimento de que o juiz é dotado (CPC, art. 131) e da prerrogativa de decidir segundo quod plerumque accidit (art. 335)." (A instrumentalidade do processo, p. 241). Similares argumentos são apresentados por DARCI GUIMARÃES RIBEIRO, O sobreprincípio da boa-fé processual como decorrência do comportamento da parte em juízo, pp. 80-82. Sobre a possibilidade de o juiz valorar condutas a despeito de prevista legal expressa, MisAEL ALBERTO se posiciona favoravelmente, com base no princípio da solidariedade e pela aplicação por analogia dos dispositivos legais que valoram a priori a conduta das partes (Valor probatório de la conducta en juicio, pp. 124-127). A prescindibilidade do texto legal é ressaltada também por INÉS WHITE, La conducta procesal de las partes y los medios de prueba, p. 157.
} 
consequências de seus atos ${ }^{463}$. Afirma-se, apenas, que essa previsão é dispensável para a realização da valoração, que já encontra bases legais em nosso sistema.

É preciso ressaltar que a conduta processual muitas vezes já é valorada a priori pelo legislador, situação que se difere da valoração feita pelo próprio juiz quando da análise do caso concreto. $\mathrm{Na}$ primeira hipótese, formam-se presunções legais sobre o comportamento das partes, ao passo que, no segundo caso, as presunções são judiciais ${ }^{464}$.

Em nosso ordenamento atual, muitas condutas processuais foram valoradas abstratamente pelo legislador. É o caso, por exemplo, da parte que se mantém inerte no momento processual adequado para oferecimento de resposta, determinando-se, por imposição legal, que diante da revelia as alegações do autor sejam presumidas como verdadeiras (art. 319 do Código de Processo Civil). Ou ainda, presumem-se verdadeiros os fatos que se visava a demonstrar por meio de exibição de documento não realizada por recusa injustificada (art. 359 do Código de Processo Civil).

Da mesma maneira, o não comparecimento da parte em juízo para prestar depoimento pessoal ou a recusa em depor tem como valor probatório a aplicação da pena de confissão, o que significa dizer que as alegações do adversário passam a ser tidas como verdadeiras na forma de presunção relativa, que pode ser afastada com base nos demais elementos probatórios dos autos (art. $342, \S 2^{\circ}$, do Código de Processo Civil).

A doutrina estrangeira chega a apontar como exemplo de valoração da conduta processual, no Brasil, a concessão da tutela antecipada fundada no abuso do direito de defesa (art. 273, inc. II, do Código de Processo Civil). Assim, ao lado da verossimilhança do direito afirmado pelo autor, a valoração da conduta da defesa como sendo abusiva ou manifestamente protelatória faz surgir a possibilidade de antecipação total ou parcial da tutela final pleiteada ${ }^{465}$.

E ainda, aquele que deixa de impugnar a autenticidade ou veracidade de um documento apresentado pela parte contrária faz com que sejam presumidas essas qualidades do documento (art. 372 do Código de Processo Civil).

\footnotetext{
${ }^{463}$ Sobre os benefícios de haver expressa disposição legal sobre a valoração, $c f$. FERNANDO HEÑIN, Modernos institutos procesales, p. 173; MARIO MASCIOTRA, La conducta procesal de las partes, p. 128.

464 "Conforme a interferência do fato probando por meio do fato provado se dê pelo juiz ou pelo legislador, fala-se em presunções judiciais e presunções legais. Essa última categoria comporta, ainda, uma subdivisão, estabelecida entre as presunções relativas (iuris tantum) e absolutas (iuris et de iure)". (LUIZ GUILHERME MARINONi e SÉrgio CruZ AREnHART, Prova, p. 132).

${ }^{465}$ FERNANDO HENIIN, Modernos institutos procesales, p. 188-189.
} 
Não só o legislador processual valorou a priori determinadas condutas das partes. Vê-se que o art. 232 do Código Civil também assim o fez ao estabelecer que "a recusa à perícia médica ordenada pelo juiz poderá suprir a prova que se pretendia obter com o exame.”.

Fora essas hipóteses legais, é possível que o juiz valore a conduta das partes por meio das presunções judiciais, o que significa dizer que o magistrado, a partir do comportamento dos sujeitos processuais e com base nas regras de experiência, possa inferir a ocorrência de fatos principais ${ }^{466}$.

Estabelecidas essas premissas, é de se indagar (i) se há diferença entre o venire contra factum proprium e a valoração judicial, bem como, sendo afirmativa a primeira pergunta, (ii) se os comportamentos processuais contraditórios podem ser valorados pelo magistrado para formação de sua convicção, evidenciando, assim, uma ligação entre venire e valoração da conduta da parte.

Parte da doutrina argentina que afirma a existência da teoria processual dos atos próprios parte do referido art. 163 , inciso $5^{\circ}$ do Código Pocesal Civil y Comercial de la Nación para ilustrá-la. Alguns afirmam que se trata da menção legal expressa que embasa a vedação aos comportamentos contraditórios ${ }^{467}$, situando a valoração da conduta processual como o maior exemplo da incidência do venire ao processo ${ }^{468}$.

Mas há autores que ressaltam a autonomia de ambas as figuras, principalmente porque a valoração da conduta das partes independe da existência de comportamentos

\footnotetext{
${ }^{466}$ Explica EDUARDO CAMBI que "as presunções judiciais, por não serem previstas nem reguladas em lei, apóiam-se, sobretudo, nas máximas de experiência, as quais servem de premissa maior para que o juiz, em um raciocínio silogístico, possa partir daquilo que ordinariamente acontece, e logo conjugar esse conhecimento com o fato seundário (indício), que lhe serve de premissa menor, para poder obter, na conclusão, a afirmação de um fato (principal), até então desconhecido." (A prova civil, pp. 376-377).

467 "Como puede observarse, esta norma importa la explícita consideración de la teoría de los propios actos aun cuando pudiera aplicarse como regla de derecho derivada del principio general de la buena fe. Es importante destacar que conforme a tal disposición, el tribunal tiene la facultad de valorar de oficio la conducta de las partes, y establecer - por ejemplo - el carácter contradictorio de las pretensiones" (OMAR LUIS DiAZ SOlIME, La buena fe en la estructura procesal, p. 870). No mesmo sentido: ALEJANDRo BORDA, La teoria de los actos propios, p. 130; MARCELO MESA e CARLOS VIDE, La doctrina de los actos propios, $\mathrm{p}$. 108.

468 'Finalmente, corresponde traer a cuento la fuerza expansiva de la doctrina de los 'propios actos' que poco a poco - va obteniendo la consagración legal de sus postulados a través del dictado de normas que regulan algunas de sus parcelas. Así, por ejemplo, sucede con el valor probatorio de la conducta en juicio (instituición que constituye la mejor prueba de la incidencia del venire contra factum en el ámbito procedimental civil y sobre la que volveremos nuevamente infra" (JORGE PEYRANO, La doctrina de los propios actos en el ámbito del procedimiento civil, p. 228). Ou ainda, ANA I. PIAGGI, Reflexiones sobre dos princípios basilares del derecho: La buena fe y los actos próprios, p. 114; OsVALDO GOZAÍNI, La conducta en el proceso, p. 220.
} 
contraditórios, bastando uma única conduta para servir de indício destinado a formar a base para a construção de uma presunção ${ }^{469}$.

Para nós, o estudo de comportamentos contraditórios não se resume à valoração judicial da conduta das partes, em primeiro lugar, e, de maneira bastante evidente, realmente pelo fato de que esta prescinde da contradição: basta um único ato ou omissão para se extrair uma valoração (como, por exemplo, no caso da recusa à realização de exame), ao passo que o venire depende do confronto entre duas condutas, ou, no limite, entre uma omissão e uma conduta. Mas, além disso, a valoração judicial da conduta processual prescinde de qualquer análise quanto à quebra de confiança ou ruptura da boafé. É possível que essa quebra exista, e que isso motive a valoração desfavorável, mas esse requisito não é essencial ${ }^{470}$, até porque, como já ressaltamos, é possível a valoração em favor do agente da conduta objeto de apreciação.

Some-se a isso o fato de que, não raras vezes, a valoração judicial é entendida como fenômeno ligado apenas ao contexto probatório ${ }^{471}$, ao passo que o venire, como já sinalizado pela jurisprudência analisada, e conforme veremos adiante, pode se dar em diferentes fases processuais, tal como na fase saneadora, como ferramenta para melhor definir a fixação de pontos controvertidos. E, ao tomarmos como escopo da valoração judicial auxiliar na formação do convencimento do juiz, mais uma vez o venire dela se diferencia considerando a possibilidade de o magistrado também ser agente de comportamentos contraditórios. Ou seja, se para a valoração judicial a conduta do juiz é irrelevante, para o venire processual, ela pode ser fundamental nos casos em que o agente da contradição é o órgão julgador ${ }^{472}$.

Outra possível - vez que existente para alguns autores, apenas, conforme supra indicado - limitação da valoração judicial está na impossibilidade de ela considerar

\footnotetext{
469 "En la valoración de la conducta procesal de las partes, si bien puede presuponer la comparación con una conducta anterior, ello no se exige como requisito de su existencia; es más, sólo exige la mirada descarnada de una exteriorización conductal, como fuente de prueba indirecta o, en su caso, como argumento o fundamento de prueba, em función cognoscitiva" (DANIEL FERNANDO ACOSTA, La conducta procesal de las partes como concepto atinente a la prueba, pp. 79-80). No mesmo sentido, $c f$. CARINA PAULA SUDILOVSKY, Reflexiones sobre la valoración judicial de la conducta en juicio. Una propuesta académica, p. 364.

${ }^{470}$ DANIEl FERNANDO ACOSTA afirma que a valoração pode se dar a partir da simples observação da conduta, desapegado de qualquer referência valorativa. (La conducta procesal de las partes como concepto atinente a la prueba, p. 82).

${ }^{471}$ Ao afastar a relevância das discussões processuais quanto à natureza jurídica da valoração judicial da conduta das partes, DANIEl FERNANDo ACOSTA afirma que "la afirmación más importante y útil que podemos hacer en relación a la conducta procesual de las partes es que la misma es un concepto que siempre resulta atinente a la prueba" (La conducta procesal de las partes como concepto atinente a la prueba, p. 99).

${ }^{472}$ MARIO MASCIOTRA, La conducta procesal de las partes, p. 135.
} 
condutas de diferentes processos, mas somente aquelas exercidas no processo em que se fará incidir a valoração, de modo a viabilizar a apreensão desde logo pelo magistrado da conduta a ser analisada. O venire, por sua vez, pode ser configurado a partir de duas condutas que não componham a mesma sede processual ${ }^{473}$.

Em resumo, pelo fato de (i) o venire exigir duas condutas que, pela contradição, (ii) afrontem a boa-fé; (iii) ele não ter por consequência apenas auxiliar a formação da convicção do magistrado - função que eventualmente pode assumir; bem como (iv) pelo juiz poder atuar de maneira contraditória, condutas que não terão qualquer relevância probatória; e porque (v) o venire poder se configurar a partir de condutas praticadas em outros processo, afirmamos a não coincidência dos institutos.

Essa coincidência pode ocorrer eventualmente, quando, em um mesmo processo, forem praticadas condutas contraditórias, que afrontem a boa-fé objetiva processual, e que também sirvam à valoração judicial, de modo a influenciarem o julgamento da demanda. Nessa hipótese, a contradição assume uma de suas possíveis funções, que é da valoração para fins probatórios.

\subsection{Autocontradicción ou intercadencia}

São poucas as referências doutrinárias encontradas sobre a autocontradicción ou intercadencia ${ }^{474}$, principalmente porque raros os textos que as elejam como objeto primordial de estudo, sendo comum sua referência de forma incidental, para compará-las com outro instituto - tal como se faz nessa oportunidade.

Utilizadas como palavras sinônimas, a autocontradición ou intercadencia são definidas de maneira ampla como um meio atípico de prova, a qual é construída a partir de presunções fundadas em indícios específicos, quais sejam, as contradições entre alegações ou condutas das partes. A intercadencia ocorre, portanto, quando uma das partes não é constante no teor de seus dizeres ${ }^{475}$.

\footnotetext{
${ }^{473}$ FERNANDO HEÑIN, Modernos institutos procesales, p. 181; MARIO MASCIOTRA, La conducta procesal de las partes, p. 135.

${ }^{474}$ E só encontramos referências a essas figuras na doutrina argentina.

${ }^{475}$ É a tradução livre do conceito recorrentemente citado, formulado por JORGE PEYRANO e JULIO CHIAPPINI: “Cuándo se da, entonces, la que hemos llamado 'prueba de intercadencia’, para el derecho procesal? Se da,
} 
Como fundamento da construção dessa prova por presunção, destacam-se os princípios da boa-fé e da cooperação e sua incidência sobre a conduta das partes, vedando a incoerência de seus comportamentos ${ }^{476}$.

Tendo em vista serem presunções construídas a partir de indícios traduzidos pelos comportamentos das partes, nítida a semelhança com a valoração da conduta processual tratada no item anterior. Poderia se dizer que a intercadencia está contida por inteiro no tema da valoração, não fosse a diferenciação doutrinária que admite a caracterização da intercadencia com base em alegações e comportamentos praticados não só no curso do processo, mas também fora dele.

Afirma-se que quando a autocontradición se dá dentro do mesmo processo, assemelha-se de forma quase total com a valoração da conduta das partes ${ }^{477}$, dela se diferenciando, porém, pela admissibilidade da configuração da intercadencia com base na contradição entre atos anteriores ao processo e outros realizados dentro dele ${ }^{478}$.

Com exemplo, indica-se a hipótese em que uma das partes, logo após a ocorrência de um acidente de trânsito, assume a culpa perante as autoridades policiais, porém, no curso do processo indenizatório posteriormente provocado pela parte contrária, nega a culpa ${ }^{479}$. Diante dessa contradição, configurada por meio da análise de condutas praticadas dentro e fora do processo, é formada a prova de intercadencia.

É certo que pelo menos um dos comportamentos tem que ser vinculado a um determinado processo ${ }^{480}$, mas é possível obter a contradição a partir de comportamentos

precisamente, cuando una de las partes litigantes no es constante en el tenor de sus dichos". (El proceso atípico, p.77).

${ }^{476}$ MARIO MASCIOTRA, La conducta procesal de las partes, p. 137.

477 A valoração da conduta das partes seria, porém, mais ampla, porque independe de comportamento contraditório ( $c f$. MARIO MASCIOTRA, La conducta procesal de las partes, p. 138).

${ }^{478}$ No original: "Cuando la autocontradición se da dentro del proceso es assimilable casi en forma total con la conducta de las partes. Aunque convengamos que la intercadencia también puede darse en cuanto a actos anteriores al proceso y relacionados con otros realizados dentro del mismo" (CARINA PAULA SUDILOVSKY, Reflexiones sobre la valoración judicial de la conducta en juicio. Una propuesta académica, p. 364). No mesmo sentido: "No obstante ello, la conducta anterior o llevada a cabo fuera del proceso, muchas veces puede servir para tener por acreditados comportamientos incoherentes o contradictorios de las propias partes, una vez abierta la instancia, pero aquí - si bien la diferencia es sutil - estaríamos frente a la llamada prueba de 'intercadencia', como manifestación de la teoría de los actos propios." (MISAEL E. AlBERTO, Valor probatorio de la conducta en juicio, p. 133).

${ }^{479} \mathrm{O}$ exemplo é de MisAEl E. AlBERTO, Valor probatorio de la conducta en juicio, p. 133.

480 "En esta orden de ideas y a mero título introductorio, corresponde comenzar por recordar en qué consiste la autocontradicción o intercadencia (especialmente desarrollada y empleada en Alemania), prueba que se da en el Derecho Procesal cuando una de las partes litigantes no es constante en el tenor de sus dichos, lo cual tiene la virtualidad de debilitar la posición procesal de quien ha incurrido en ella. Ahora bien, ello es estrictamente así cuando la intercadencia se da en relación a los actos desarrolados en el mismo proceso, o extrajudicialmente, pero siempre en vinculación con dicho proceso" (SILVINA PEREIRA MARQUES, 
endo ou extraprocessuais (incluindo-se, aqui, comportamentos de outros processos), o que, para a doutrina Argentina, corresponde ao ponto de confluência entre valoração da conduta das partes e a teoria dos atos próprios ${ }^{481}$.

Ressalta-se na doutrina que a autocontradicción não pode advir do silêncio, fazendo-se necessária a existência de duas condutas contraditórias comissivas ${ }^{482}$.

Interessante a conclusão que decorre da configuração da intercadencia: uma vez caracterizada a contradição entre alegações ou condutas praticadas por uma mesma parte, o órgão jurisdicional poderá tomar como verdadeira, dentre as versões contraditórias apresentadas, a que mais desfavoreça a parte que incidiu em contradição, verdade que se constrói, portanto, por meio de uma presunção iuris tantum ${ }^{483}$.

Isso significa dizer que, em razão da contradição, é formada uma presunção relativa, a qual admite prova em contrário. Além disso, essa contradição é analisada conforme os demais elementos probatórios dos autos e somente faz sentido invocar a intercadencia se dela resultarem vantagens à parte que se contradisse, ou ainda, se gerarem desvantagem à parte adversa.

Essa é a lição depreendida de um caso julgado pela Suprema Corte de Justiça de Buenos Aires ${ }^{484}$, segundo a qual, quando uma mesma parte oferece versões distintas sobre um mesmo fato, tal dualidade acarreta debilidade da posição processual de quem incorreu em contradição, configurando-se a intercadencia. Porém, se dessa contradição não sobrevierem vantagens ao sujeito contraditório, ou desvantagens à parte adversa, o uso do senso crítico do julgador impõe que não sejam construídas presunções diante dessa realidade.

Relexiones acerca de alguns aspectos de la valoración de la conducta procesal de las partes desplegada en procesos distintos (conexos o no), p. 313).

${ }^{481}$ DANIEL FERNANDO ACOSTA, La conducta procesal de las partes como concepto atinente a la prueba, $\mathrm{p}$. 80.

482 Jorge PEYRANO e JUlio ChIAPPINI, El proceso atípico, p. 83.

${ }^{483}$ JORGE PEYRANO e JULIO CHIAPPINI, El proceso atípico, p. 86; MARIO MASCIOTRA, La conducta procesal de las partes, p. 136; JORGE PEYRANO e JULIO CHIAPPINI, Informe sobre la doctrina de los propios actos en el campo procesal, p. 680. "La prueba de intercadencia se da en el Derecho Procesal, cuando una de las partes litigantes no es constante en el tenor de sus dichos. Y ello sucede muchas veces dentro de la peripecia procesal. Tiene la virtualidad de debilitar la posición procesal de quien ha incurrido en ella; se trata de una prueba presuncional (iuris tantum) en su contra, éstandole permitido al tribunal tomar de las varias versiones de la parte autocontradictoria la que más favorece a la posición de su ocasional contraria. Por ello, cuando la intercadencia se da en relación a los actos desarollados en el proceso, la coincidencia de ambos conceptos es total;" (DANIEL FERNANDO ACOSTA, La conducta procesal de las partes como concepto atinente a la prueba, pp. 80-81).

${ }_{484}$ (Suprema Corte de Justiça de Buenos Aires, fallo n. 258.160, julgado em 10.02.2011. Disponível em: <http://www.scba.gov.ar>. Acesso em: 04 abr. 2014). 
Essas conclusões foram tiradas de caso em que, em uma ação indenizatória de uma cliente contra seu banco - por ter sido vítima de fraude ao tentar sacar dinheiro e seu cartão ter ficado preso no caixa eletrônico, posteriormente sido utilizado por terceiros para ilicitamente sacar o dinheiro de sua conta -, a autora se contradisse porque, em sua primeira versão, disse que ela mesma foi ao banco, ao passo que, em um segundo momento, afirmou que o seu cônjuge era quem tentara tirar dinheiro. Frente a isso, o Tribunal entendeu que não se aplicam as consequências da intercadencia porque a contradição foi irrelevante, sem trazer quaisquer benefícios à autora ou prejuízos ao banco. $^{485}$.

Diante desse contexto, pergunta-se, uma vez mais, a relação entre o venire contra factum proprium processual e a intercadencia.

Considerando que a intercadencia está quase totalmente inserida no gênero da valoração da conduta processual, sendo mais específica porque se dá a partir de comportamentos contraditórios, porém mais ampla porque pode considerar condutas praticadas fora do processo, tem-se que duas das diferenciações formuladas no item anterior desaparecem: justamente o fato de aqui ser também necessária a contradição, a qual pode se dar entre comportamentos praticados dentro e fora da sede processual.

Dessa maneira, a autocontradicción aproxima-se do nosso objeto de estudo, porém com ele não coincide em sua totalidade por ainda restarem as demais diferenças, quais sejam: (i) a intercadencia tem finalidade apenas probatória ${ }^{486}$, (ii) ela independe de

\footnotetext{
${ }^{485}$ Assim, nas palavras do Tribunal: "No desconoce quien esta votando la teoría procesal de la 'intercadencia': cuando un misma parte ofrece versiones distintas de un mismo hecho, tal dualidad origina el debilitamiento de la posición procesal de quien ha incurrido en la mentada contradicción (Cfe. Gozaini, Osvaldo 'La conducta en el proceso' pag. 217; esta sala causa $N^{\circ} 51.664$ R.S. 20/05); pero no es menos cierto que la 'intercadencia' debe apreciarse en función de la totalidad del plexo probatorio que determinara las circunstancias de cada caso; elemento fundamental para tener en cuenta es si la disímil versión logro un beneficio y/o provoco un perjuicio para quien la brindo; y ello implica una interpretación lógica abalizada por la sana critica (Art.384 del C.P.C.C.) de la 'intercadencia', no aferrándose al mero aspecto literal o formal sino aplicándola en función de su espíritu que no es otro que el antes expuesto. Y en el caso de autos no tengo duda que la diferente versión brindada por la actora no busco ni por ende logro ventaja procesal alguna ni tampoco fue motivo de perjuicio para la demandada; ello hasta tal punto que la expresión de agravios se limita al aspecto formal no ensayando argumento alguno que demuestre la ventaja y/o el perjuicio." (Suprema Corte de Justiça de Buenos Aires, fallo n. 258.160, julgado em 10.02.2011. Disponível em: <http://www.scba.gov.ar>. Acesso em: 04 abr. 2014).

${ }^{486}$ Nesse sentido, JORGE PEYRANO e JULIO CHIAPPINI afirmam que: "No se piense, tampoco, que la susodicha teoría [dos atos próprios] opera únicamente en el área del material de conocimiento de la causa, porque también podría funcionar en el área alegatoria (cuando, por ejemplo, una misma parte extrae conclusiones del material probatorio colectado que resultan contradictorias al cotejar el tenor del alegato de bien probado y el de la expresión o contestación de agravios). E, incluso podría invocársela para desestimar peticiones formuladas durante la sustanciación de la causa (aunque no se tratase de pretensiones incidentales o análogas) que vinieran a contradecir claramente manifestaciones o solicitudes anteriores" (Informe sobre la doctrina de los propios actos en el campo procesal, p. 681).
} 
análise da quebra da boa-fé processual objetiva, (iii) ela só gera um efeito (adotar a versão menos favorável) e (iv) ela não possui qualquer relação com os comportamentos do órgão julgador.

Haverá coincidência, portanto, quando, pela afronta à boa-fé, a contradição das partes servir de indício a gerar uma presunção para fins probatórios. A conclusão é coincidente como a do item anterior: a intercadencia retrata uma das possíveis consequências da adoção de comportamentos processuais contraditórios.

\subsection{Estoppel}

O estudo do estoppel apresentou dificuldades na medida em que nos deparamos com diversas referências a essa figura ao longo de nossos estudos, todas com o escopo comparativo com o venire, mas, ao aprofundarmos a pesquisa, não foi possível encontrar material doutrinário suficiente para esclarecer todas as dúvidas quanto à funcionalidade do estoppel como rule of evidencie. Optamos, porém, por trazer tudo que foi encontrado, para que não passe desapercebida a semelhança dessa figura com o venire.

O estoppel é um instituto proveniente da common law e, como a maioria dos conceitos nela desenvolvidos, tem origem jurisprudencial ${ }^{487}$. A definição recorrente na doutrina inglesa sobre estoppel é aquela formulada por LORD DENNING, para quem o estoppel é um princípio da justiça e equidade, segundo o qual, quando um homem, por suas palavras ou conduta, faz com que outrem deposite confiança em uma determinada situação, ele não está autorizado a voltar atrás quando isso significar quebra de justiça ${ }^{488}$.

Dessa maneira, por meio do estoppel, que etimologicamente significa justamente impedimento, obstáculo, detenção ${ }^{489}$, uma pessoa está impedida de negar um estado de fato que ela tenha estabelecido como verdadeiro, veracidade que pode ser

\footnotetext{
${ }^{487}$ DIEZ PICAZO, La doctrina de los propios actos, p. 63.

${ }^{488}$ No original: "Estoppel...is a principle of justice and of equity. It comes to this: when a man, by his words or conduct, has led another to believe in a particular state of affairs, he will not be allowed to go back on it when it would be unjust or inequitable for him to do so". As palavras foram proferidas durante um dos julgamentos do juiz Lord Denning, conforme referências expostas em ELIZABETH COOKE, The modern law of estoppel, p. 2, nota 5.

${ }^{489}$ DIEZ PICAZO, La doctrina de los propios actos, p. 62.
} 
construída de maneira expressa, por meio de palavras proferidas, ou implicitamente, através da conduta assumida em momento anterior ${ }^{490}$.

Note-se que a definição de estoppel é bastante genérica e abstrata. E essa necessidade de abstração advém do fato de que, para a maioria dos autores, o estoppel é categoria ampla que se divide em várias espécies, cada qual com características próprias. Assim, em princípio, a maior precisão do conceito implicaria confusão entre categorias, razão pela qual o conceito é comumente elaborado abstratamente, seguindo-se o estudo das categorias específicas ${ }^{491}$.

É impertinente ao nosso objeto de estudo aprofundarmos as noções sobre cada espécie de estoppel, que são várias e principalmente relativas ao direito material, dentre as quais, as mais comumente mencionadas: estoppel by record, estoppel by deed, estoppel by fact in pains, estoppel by representation e estoppel by acquienscence ${ }^{492}$. O estudo de todas elas demandaria que o estoppel fosse ele próprio o objeto da dissertação, a qual, por sua vez, deveria ser elaborada sob o enfoque majoritariamente do Direito Civil, e não do Processo, uma vez que a figura tem ampla aplicação para proteção da confiança no âmbito do direito material.

${ }^{490}$ Osvaldo GOZAínI, La conducta en el proceso, p. 221.

491 Bastante ilustrativas as palavras de LORD DENNING quanto a essa relação de abstração do conceito e divisão do estoppel em diferentes categorias: “...there has been built up over the centuries in our law a big house with many rooms. It is the house called Estoppel...By our time we have so many rooms that we are apt to get confused between them. Estoppel per rem judicatam, issue estoppel, estoppel by deed, estoppel by representation, estoppel by conduct, estoppel by acquiescence, estoppel by election or waiver, estoppel by negligence, promissory estoppel, proprietary estoppel and goodness knows what else. These several rooms have this much in common: they are all under one roof. Someone is stopped from saying something or other, or doing something or other, or contestin something or other. But each room is used differently from the others." (ELIZABETH COOKE, The modern law of estoppel, p. 3).

${ }^{492}$ Aparentemente, não há um só critério diferenciador dessas modalidades de estoppel. Por exemplo, o estoppel by deed consiste no impedimento de contradizer declaração constante de documento selado, ou seja, " a deed is a document which makes it clear on its face that is intended to be a deed, and is properly executed and delivered" (ELIZABETH COOKE, The modern law of estoppel, p. 7), conceito traduzido por PUIG BRUTAU como sendo escritura ou documento público (Estudios de derecho comparado, p. 109). Já o estoppel by fact in pains, em sua origem, é a vedação de quem concedeu um direito sobre sua propriedade revogar essa concessão, principalmente quando o negócio não se firmou mediante documentação solene apta a invocar o estoppel by deed. Trata-se de um conceito limitado ao contexto da concessão de direitos sobre propriedade (ELIZABETH COOKE, The modern law of estoppel, pp. 8-10).

$\mathrm{O}$ estoppel by representation é visto como uma evolução do estoppel by fact in pains, traduzindo-se pela impossibilidade de negar uma situação criada por seus próprios atos ou palavras, situação confiada por terceiros Note-se que sua aplicação é bem mais extensa do que os dois últimos exemplos (ELIZABETH COOKE, The modern law of estoppel, pp. 17-18).

Por fim, dentre as espécies de estoppel referidas (que, frise-se, estão longe de abarcar todas as modalidades existentes), o estoppel by acquiescence é aquele fundado na omissão, na representação criada a partir de uma inação: "La aquiescencia o la inacción son en determinados supuestos causa de un 'estoppel'. La inacción se presenta como un equivalente de la representación. En la doctrina inglesa se razona así: una representación, según sabemos, puede ser originada por palabras o por actos, es decir, por medio del lenguaje o por medio de la conducta. La inacción es un tipo de conducta, es una conducta pasiva u omisiva que, por tanto, puede ser también fuente de una representación." (DIEZ PICAZO, La doctrina de los propios actos, p. 83). 
O enfrentamento da matéria na seara do Processo Civil, por sua vez, tem relevância quando o estoppel é analisado sob as seguintes perspectivas: (i) como impedimento para decidir novamente questões já enfrentadas em decisão judicial anterior; e (ii) como rule of evidence.

A primeira perspectiva, apesar de relevante para o Processo, não apresenta importância para nosso objeto de estudo. Trata-se do estoppel by record, estoppel by matter of record ou estoppel per rem judicatam, segundo o qual uma questão que já fora resolvida em um processo não pode ser novamente invocada pelas partes para uma segunda apreciação ${ }^{493}$, à semalhança do papel desenvolvido pela coisa julgada material em noss sistema ${ }^{494}$.

Não nos cabe aprofundar essa relação entre estoppel by record e coisa julgada material porque a compreensão desta não é tema de nossas investigações. Como bem diferencia ELIZABETH COOKE, o estoppel by record distingue-se das demais modalidades pelo fato de o impedimento da alteração da situação estar na existência de decisão judicial anterior, e não nas palavras ou condutas praticadas pelo sujeito ${ }^{495}$. Em nosso sistema, a impossibilidade de contrariar decisão anterior é regulada pela coisa julgada, sem que essa contradição precise ser vedada pelo nemo potest venire contra factum proprium.

Assim, interessa-nos a referência do estoppel como rule of evidence.

\footnotetext{
${ }^{493}$ Assim ADRIAN ZUCKERMAN define estoppel per rem judicatam: "It means that a decision of a court of competent jurisdiction gives rise to estoppel per rem judicatam so that the parties to the proceedings are bound by it and estopped from disputing it in future proceedings. This general doctrine of estoppel per rem judicatam consists of two distinct rules known as causa of action estoppel and issue estoppel. Causa of action estoppel implies that once a causa of action has been adjudicated, the parties to the proceedings are estopped from asserting or denying (as the case may be) that particular causa in any subsequent proceedings to which they are also parties. (...) The related doctrine of issue estoppel holds that parties to legal proceedings are bound by the court's finding on discrete issues that are essential to the final resolution of the proceedings in which the findings were made." (Civil procedure: principles of practice, pp. 1238-1239).

${ }^{494}$ A relação entre coisa julgada material e estoppel by record é assim feita: "En realidad, [el estoppel by record] se trata de una reminiscencia del antiguo Derecho germânico, que desconocía la verdadera eficácia de cosa juzgada de las sentencias, en el sentido moderno. Consistió originariamente en un auténtico estoppel, es decir, en una prohibición de ir contra los propios actos, pues se trataba de impedir a uma de las partes que desconociera la situación que ella misma había creado o había contribuído a crear. No era la alegación de la sentencia firma lo que producía el efecto paralizador, como modernamente ocurre, sino el hecho de que su pretendido desconocimiento implicaba ir contra los propios actos representados por cuanto habían alegado o admitido las partes al seguir el procedimiento" (PUIG BRUTAU, Estudios de derecho comparado, pp. 109110); "La idea del 'estoppel by record' es la seguiente: quien ha colaborado mediante su conducta procesal a que un determinado punto litigioso quede fijado o decidido en una sentencia, no puede después hacer una afirmación que contradiga la sentencia. Según esto, ir contra la sentencia es ir contra la propia obra, en cuanto que la parte ha colaborado para que la sentencia sea dictada" (DIEZ PICAZO, La doctrina de los propios actos, p. 72).

${ }^{495}$ The modern law of estoppel, p. 6.
} 
É frequente na doutrina a afirmação de que o estoppel funciona como uma regra de prova no processo ${ }^{496}$, de modo a vedar que um sujeito alegue a falsidade de situação que ele mesmo criara a partir de suas palavras ou condutas. Essa vedação se dá por meio da construção de uma presunção absoluta de que a situação criada é verdadeira, impedindo-se as tentativas de demonstração em sentido contrário ${ }^{497}$.

A caracterização do estoppel como rule of evidence não prescinde de uma aparência jurídica construída pelo mesmo sujeito que depois pretende contradizê-la. E essa aparência precisa ser de tal maneira que inspire a confiança em terceiros ${ }^{498}$. Além disso, os atos ou palavras de que se origina a confiança podem ter sido praticados dentro ou fora do processo $^{499}$.

Presentes esses requisitos, o estoppel produz efeitos puramente processuais, sem modificar, extinguir ou criar uma relação jurídica, mas apenas vedando a alegação em sentido contrário à situação confiada, tornando-a inadmissível no processo ${ }^{500}$.

Dessa breve exposição, nota-se a manifesta semelhança entre estoppel e venire contra factum proprium. DIEZ PICAZO chega a afirmar que, se há dúvidas quanto ao parentesco histórico, o parentesco ideológico é certo ${ }^{501}$, porquanto ambos têm a mesma

${ }^{496}$ ANA I. PIAGGI, Reflexiones sobre dos princípios basilares del derecho: La buena fe y los actos próprios, pp. 125-126; DIEZ PICAZO, La doctrina de los propios actos, p. 63; PUIG BRUTAU, Estudios de derecho comparado, p. 115.

497 "Dicho em otros términos, la doctrina del estoppel es la regla del Derecho anglosajón que, por virtud de una presunción iuris et de iure, impide jurídicamente el que una persona afirme o niegue la existencia de um hecho determinado, en virtud de haber antes ejecutado un acto, hecho una afirmación o formulado uma negativa en el sentido precisamente opuesto; pues conforme a este principio, nadie puede contradecir lo dicho o hecho por el mismo o por aquel de quien se derive su derecho, de un modo aparente y ostensible, com perjuicio de un tercero que, fiado en esas apariencias, producidas intencional o negligentemente por el responsable de ellas, contrae una obligación o sufre um perjuicio en su persona o en su patrimônio" (PUIG BRUTAU, Estudios de derecho comparado, pp. 104-105). No mesmo sentido: "De maneira geral, a estoppel significa um princípio processual integrante das regras de prova (rules of evidence) que impede, em virtude de uma presunção iuris et de iure, um pessoa de afirmar ou negar a existência de um fato determinado se antes exercitara o ato, fizera uma afirmação ou formulara uma negativa em sentido precisamente oposto". (JUDiTh MARTINS-CostA, A ilicitude derivada do exercício contraditório de um direito, p. 113). "La idea es ésta: una persona debe dejar valer contra ella determinados actos o determinada situación sin posibilidad de probar su inexactitud. El 'estoppel' es así una vinculación a la inexactitud y, en este sentido, ofrece algunas semejanzas con las "presunciones juris et jure"” (DIEZ PICAZO, La doctrina de los propios actos, p. 70).

498 "Como puede observarse, el núcleo de la figura del estoppel es la 'apariencia', o mejor aún, es la confianza depositada en esa apariencia jurídica y la buena fe derivada de la confianza suscitada. Por ello, se habla de la protección objetiva de la apariencia jurídica en la medida en que se protege la confianza y la buena fe considerando los actos efectuados y la contradición que objetivamente pudiere existir." (ALEJANDRO BORDA, La teoria de los actos propios, p. 29).

${ }^{499}$ AlEJANDRO BordA, La teoria de los actos propios, pp. 30-311.

${ }^{500}$ DIEZ PICAZO, La doctrina de los propios actos, p. 68.

501 DiEZ PICAZO, La doctrina de los actos propios, p. 64. No mesmo sentido: "Las investigaciones y el derecho vivo de los tribunales muestran que el 'venire contra factum proprium', el 'estoppel' y la 'verwirkung' son variantes que se polarizan en el derecho actual para descalificar jurídicamente, en determinadas circunstancias la propria conducta. (...) Si bien la doctrina angloamericana afirma que el 
finalidade de proteção da confiança criada, vedando-se o comportamento em sentido contrário.

JOAN PICÓ I JUNOY sustenta que o estoppel é a regra do fair play processual do direito anglosaxão, papel desempenhado pela doutrina dos atos próprios, que não deixa de se destinar também à regulação do direito material ${ }^{502}$. O pensamento é compartilhado por JORGE PEYRANO, que entende ser o venire contra factum uma figura mais ampla por tratar da matéria substantiva e também processual ${ }^{503}$.

E, por fim, arremata PUIG BRUTAU sustentado as semelhanças entre as figuras pelo fato de ambas exigirem (i) duas condutas de um sujeito (ii) que gerem uma situação contrária à da realidade aparente e (iii) e da qual surja uma confiança de maneira tal a causar prejuízos naquele que confiou. Assim, ambas possuem a mesma finalidade, qual seja, a de aplicar o princípio fundamental que exige proteger a boa-fé depositada na aparência $^{504}$.

Fica feita, assim, a referência à figura do estoppel, instituto que cumpre papel similar ao conceito de vedação de comportamentos processuais contraditórios proposto por este trabalho, ressaltando-se que, no que diz respeito ao venire, eventuais construções de presunções a partir da contradição de comportamentos não é feita de maneira absoluta, mas apenas relativa, admitindo-se prova em sentido contrário.

\footnotetext{
'estoppel' es una instituición peculiar del 'common law'; como se senãlo existe un parentesco ideológico innegable entre el 'estoppel' y el 'venire...' y en general el primero involucra una cantidad de hipótesis más estrecha que el segundo." (ANA I. PIAGGI, Reflexiones sobre dos princípios basilares del derecho: La buena fe y los actos próprios, pp. 124-125).

${ }_{502}$ JOAN PICÓ I JUNOY, El principio de la buena fe procesal, pp. 126-127.

503 Jorge PEYRANO, La doctrina de los propios actos en el ámbito del procedimiento civil, p. 229.

${ }^{504}$ Estudios de derecho comparado, pp. 112-114.
} 


\section{VENIRE E PRECLUSÃO}

Para que preclusão e venire possam ser comparados - pois, como enunciado logo na Introdução deste trabalho, é constante a aproximação feita pela doutrina entre preclusão lógica e venire -, é preciso delimitar as premissas do que se entende por preclusão, pois, dependendo da concepção que se adote, as figuras podem se assemelhar ou apresentar diferenças substanciais entre si.

A grande dificuldade, porém, está no fato de que a preclusão é, per si, instituto bastante complexo, e sobre o qual recaem opiniões doutrinárias diversas. Tentaremos problematizar o mínimo possível esse conceito, porque o escopo é enfrentar as questões que envolvem o comportamento contraditório das partes e do juiz, e sua relação com a preclusão lógica.

Assim, como ponto de partida, esclarece-se que partimos da premissa de que a preclusão dirigida à atividade das partes e a preclusão sobre questões incidentais são fenômenos diversos ${ }^{505}$ : apesar de existirem semelhanças, as peculiaridades são tantas que acabam por tornar distintos os fenômenos constantemente chamados igualmente de preclusão, sem ressalvas.

No item a seguir, buscaremos estudar as noções básicas do que se entende por preclusão, tratando, portanto, dos elementos comuns entre as preclusões das partes e do juiz. Em seguida, será feito um estudo um pouco mais aprofundado para que se compreenda o mecanismo da preclusão sobre a atividade das partes e aquela incidente sobre questões incidentais já decididas, para que, ao final, seja feita a comparação pretendida com a adoção de comportamento processual contraditório.

\footnotetext{
505 Essas são as conclusões a que chegou HEITOR VITOR MENDONÇA SiCA, na obra Preclusão processual civil, a qual servirá de principal base para nossos estudos a respeito da preclusão, por ser um trabalho bastante completo sobre o tema, e por conter conclusões que dificilmente provocam nossa discordância. Apesar de não nos olvidarmos das preocupações do autor com o rigor terminológico, utilizaremos como sinônimo de "preclusão dirigida à atividade das partes" a expressão "preclusão para as partes", e, da mesma maneira, será considerado sinônimo de "preclusão sobre questões incidentais" o termo "preclusão para o juiz", para que a leitura possa ser mais fluida. Acreditamos que, ao ressaltarmos, em diferentes momentos, a não coincidência dos fenômenos, a flexibilização desse rigor não implicará confusões conceituais.
} 


\subsection{Noções gerais: conceito, natureza jurídica, finalidade e extensão dos efeitos}

Talvez o primeiro ponto incontroverso da doutrina que se dispôs a estudar a preclusão em geral seja reconhecer que o grande estudioso do tema foi CHIOVENDA ${ }^{506}$, o verdadeiro responsável por conferir caráter científico ao instituto, por identificar esse fenômeno jurídico que se repetia em inúmeros dispositivos legais, nomeá-lo e classificá-lo em diferentes hipóteses ${ }^{507}$. Assim, ressalta-se que a preclusão possui manifestações legais pontuais, mas não é disciplinada pela lei de maneira didática e unificada ${ }^{508}$.

É certo que, após a elaboração teórica da preclusão por CHIOVENDA, muitos estudos contribuíram para melhor aclarar o conceito e suas diferentes manifestações. Por exemplo, apesar de ser imprecisa a afirmação de que CHIOVENDA não chegou a vislumbrar a possibilidade de as preclusões obstarem o exercício de posições jurídicas das partes e também dos juízes ${ }^{509}$, tal distinção somente foi se tornando mais bem delineada pela doutrina subsequente ${ }^{510}$.

E, justamente por causa desse aprimoramento da teoria, seria impreciso conceituar de maneira suficientemente ampla - englobando-se o fenômeno da preclusão

\footnotetext{
${ }^{506}$ Assim afirmam, quanto à originalidade de CHIOVENDA na sistematização do estudo da preclusão, FREDIE Didier JR. e PEDRO NogueIRA. Teoria dos fatos jurídicos processuais, p. 157; CElso AgríCOLA BARBI, Da preclusão no processo civil, pg. 62; MANOEL CAETANO FERREIRA FILHO, A preclusão no direito processual civil, pp. 19-20; HuMBERTO THEODORO JúNIOR, A preclusão no processo civil, p. 12. Com isso, não se afirma que não existam referências históricas anteriores sobre esse instituto, mas apenas que CHIOVENDA sistematizou e classificou a preclusão em suas diferentes manifestações, conferindo-lhe caráter científico. Sobre esse histórico anterior, $c f$. HEITOR VITOR MENDONÇA SICA, Preclusão processual civil, pp. 6-51, RAQUel MARIANO DA ROCHA, Preclusão no processo civil, pp. 17-24.

507 Ao refutar algumas das críticas que D’ONOFRIO formulou aos seus estudos sobre a preclusão, CHIOVENDA afirma que "Posta la perdita della facoltà come elemento essenziale della preclusione, questa idea (che non deriva da construzione dottrinale, ma da semplice e modesta analisi ed osservazioe della lege) non apparirà né irrazionale, né troppo vaga, né tanto vasta da abbracciare quase tutto il processo!" (GIUSEPPE CHIOVENDA, Cosa giudicata e preclusione, p. 233), revelando, assim, a fonte direta de seus estudos a partir da observação da lei.

508 ANTONIO DO PASSO CABRAL afirma que "a preclusão é um instituto construído em grande medida sem norma legislada" (Coisa julgada e preclusões dinâmicas, p. 41).

${ }^{509}$ Nesse sentido são as palavras de ANTÔNIO ALBERTO ALVES BARBOSA: "Como se vê nos tratadistas citados, principalmente em Riccio e em Andrioli, não há a menor dúvida de que a preclusão atinge também o juiz. Todavia, Chiovenda, ao definir a essência do instituto em apreço, não contemplou a preclusão da decisão das questões, pelo que a definição ficou insuficiente para abranger todos os casos que ele, com a sua inigualável mestria, apresentou e estudou" (Da preclusão processual civil, p. 51).

${ }^{510}$ Como já afirmado, HeITOR VITOR MENDONÇA SICA divide toda abordagem do seu estudo da preclusão a partir dessa diferenciação: "Se os sujeitos do processo ocupam posições jurídicas diferentes uns dos outros, o fenômeno que os impede de exercitar seus poderes dentro da relação jurídica processual se dá de forma diversa, e informado por princípios próprios. Essa é mais uma razão que reforça nossa posição de enfrentar separadamente a preclusão dirigida às partes e a preclusão dirigida ao juiz." (Preclusão processual civil, p. 108). No mesmo sentido a divisão é ressaltada, sob a perspectiva do objeto da preclusão, por MAURÍCIO GIANNICO, A preclusão no direito processual civil brasileiro, pp. 128-129; CELSO AGRíCOLA BARBI, Da preclusão no processo civil, p. 62.
} 
para as partes e para o juiz - e, ao mesmo tempo, de forma precisa - excluindo-se situações que com a preclusão não se confundem - o que venha a ser preclusão.

Como exemplo, pode-se citar a definição de Antônio Alberto Alves BARBOSA, que, ao ter o mérito de identificar a diferenciação entre a preclusão para as partes e para o juiz ${ }^{511}$, ampliou o conceito para incluir ambos os fenômenos, afirmando ser a preclusão “o instituto que impõe a irreversibilidade e a auto-responsabilidade no processo e que consiste na impossibilidade da prática de atos processuais fora do momento e da forma adequada, contrariamente à lógica, ou quando já tenham sido praticados, válida ou invalidamente" ${ }^{, 512}$.

O conceito é bastante eficiente ao buscar unir as preclusões das partes e do juiz. Porém, é insuficiente para distinguir as peculiaridades - basta pensar que, como veremos a seguir, a simples prática do ato não é motivo per si para obstar a parte de exercê-lo novamente, o que é realidade para a preclusão para o juiz -, sendo, portanto, incompleto. Além disso, ao incluir a palavra "validamente", esse conceito não está em consonância com a parte da doutrina moderna com a qual concordamos.

Aprofundaremos adiante essas problemáticas. Por ora, ressalta-se que a melhor opção para definir o regime das preclusões seria afirmar ser a preclusão, no que compete às partes, a consequência consistente na perda da possibilidade de exercer um ônus processual fora do termo legal ou por incompatibilidade lógica com o exercício de uma situação jurídica processual anterior, e, no que se refere ao juiz, é a consequência consistente na perda da possibilidade de reanalisar uma questão já decidida.

Com relação à natureza jurídica da preclusão, afasta-se a possibilidade de ela ser sanção ${ }^{513}$, vez que não é consequência da inobservância de deveres. Da mesma maneira, não é um ato processual, já que a preclusão não é praticável per si, manifestandose apenas como consequência da prática (ou não) de atos processuais ${ }^{514}$.

511 “Há, portanto, além da preclusão das faculdades das partes, a da decisão das questões, sobremaneira importante, que deixou de ser contemplada na definição de Chiovenda, embora ela ressalte nítida de suas magníficas lições" (Da preclusão processual civil, p. 37).

512 Antônio Alberto Alves BARBOSA, Da preclusão processual civil, p. 52.

${ }^{513}$ Há de se ressalvar, porém, que FREDIE DIDIER JR. e PEDRO NoGUEIRA admitem a existência de uma preclusão-sanção, incidente diante da prática de ato ilícito processual. Sobre o tema, cf. Teoria dos fatos jurídicos processuais, pp. 167-169.

${ }_{514}$ EGAS DIRCEU MONIZ DE ARAGÃo afirma que "Embora surja sempre e necessariamente como efeito - (a preclusão não é um ato, não é, pois, praticável; só pode acontecer como resultado) - a verificação desse fato processual origina consequências, das quais, portanto, é causa, o que é natural em vista de os atos e fatos do processo se encadearem numa sequência preordenada a um fim” (Preclusão, pp. 145-146). 
Disso se conclui, com frequência, que ela é fato jurídico processual, ou seja, um acontecimento a que a lei processual confere efeitos jurídicos processuais, sendo esse efeito o impedimento da prática de uma posição jurídica processual anteriormente autorizada $^{515}$. Mas, segundo HeITOR VITOR MENDONÇA SiCA, também não é fato jurídico, porque ela não é um acontecimento observado no mundo real, "mas sim a própria consequência jurídica atribuída por lei a um determinado fato ou ato processual" incidente sobre fato quando baseada no decurso do tempo (preclusão temporal), e sobre ato quando veda a incompatibilidade lógica de condutas (preclusão lógica).

Diante disso, afirma o autor ser a preclusão um princípio, um instituto e uma técnica. É princípio por ser uma exigência genérica de qualquer processo, é instituto porque dotada de contornos científicos, que permitem diferenciá-la de outras figuras, e é técnica do legislador processual para evitar que as partes atuem no processo conforme seus interesses privados ${ }^{517}$. Para nós, todavia, a preclusão não é princípio porquanto não traz um valor per si, mas apenas uma técnica processual destinada a concretizar os valores elencados como correspondentes à sua própria finalidade.

Interessa-nos, justamente, investigar as finalidades da preclusão, ou seja, o seu papel dentro do sistema jurídico processual.

Em sua origem, a preclusão foi vislumbrada como um instituto essencial à marcha do processo, responsável por impulsionar de maneira célere o seu desenvolvimento, colocando limites ao exercício de determinadas faculdades processuais e, dessa maneira, portando-se como um grande limitador de liberdades ${ }^{518}$. Este, portanto, pode ser identificado como o núcleo duro do conceito da preclusão em sentido amplo: um instituto destinado a conferir celeridade e progressão à marcha do processo, por meio da limitação ao exercício de posições jurídicas processuais.

\footnotetext{
${ }^{515}$ RaQUel MARIANO Da ROCHA, Preclusão no processo civil, p. 37.

${ }_{517}^{516}$ HeITOR VITOR MENDONÇA SiCA, Preclusão processual civil, p. 178.

${ }^{517}$ HeItor Vitor MENDONÇA Sica, Preclusão processual civil, p. 178. De acordo com Fernando Rubin, peclusão é também princípio e técnica (A preclusão na dinâmica do processo civil, pp. 35-41). Segundo CARlos AlBerto Alvaro DE Oliveira, técnica é conceito empregado nesse contexto como "conjunto de meios e procedimentos para garantir a realização das finalidades gerais ou particulares do direito" (Do formalismo no processo civil, pp. 170-171), inserindo-se a preclusão como técnica porque "pode-se também aplicar, com maior ou menor intensidade, a técnica de que a inobservância da ordem legal e do prazo assinado às atividades processuais acarreta como consequência a preclusão da faculdade de cumpri-los ou continuá-los (técnica da preclusão)" (Do formalismo no processo civil, p. 176), ou seja, segundo os valores eleitos pelo ordenamento processual.

${ }^{518}$ Carlos Alberto Alvaro de Oliveira, Do formalismo no processo civil, p. 227.
} 
Conferir à preclusão a finalidade primordial de impulsionar o processo é uma constante na doutrina $^{519}$, o que nos faz identificar como sendo esse o principal escopo da preclusão, escopo que contribui para a efetividade processual. Porém, outras finalidades são atribuídas ao instituto.

A segurança jurídica é apontada como uma finalidade ${ }^{520}$ : a possibilidade, em abstrato e ilimitada, de se exercer determinada situação jurídica processual geraria uma incerteza e insegurança na parte adversa, que só se extinguiria com a prática do ato em si, não fosse a funcionalidade da preclusão. Em outras palavras, sem a preclusão, a expectativa com relação à prática ou não de determinada posição jurídica seria indefinida, e a continuidade do processo seria constantemente prejudicada, porquanto um sujeito processual poderia ser supreendido com a retomada de atos e questões que acreditava terem ficado para trás. Em razão disso, é possível afirmar que, ao impulsionar adiante o processo, a preclusão age em prol da segurança jurídica, assegurando que o processo não traga surpresas, seguindo sempre adiante ${ }^{521}$.

A relação entre boa-fé processual e preclusão é também feita. Afirma-se que, por meio da preclusão, impede-se o exercício de manobras processuais de má-fé ${ }^{522}$, bem como se encontram referências doutrinárias que relacionam a preclusão lógica com a boafé $^{523}$, sendo a preclusão lógica a expressão do venire contra factum proprium processual, responsável por proteger a confiança e a boa-fé processual ${ }^{524}$.

\footnotetext{
${ }^{519}$ ChIOvenda, Cosa giudicata e preclusione, p. 232. Na doutrina moderna, destacam-se as palavras de José ROBERTO DOS SANTOS BEDAQUE: "A preclusão é uma entre as várias técnicas destinadas a evitar a demora do processo. Aliás, visa a possibilitar o próprio desenvolvimento dele, estabelecendo limites à prática de atos pelas partes e à discussão de questões processuais, a fim de que, mediante impulso oficial, se chegue ao exame da situação substancial, com a concessão ou a denegação da tutela jurisdicional" (Efetividade do processo e técnica processual, p. 128). HEITOR VITOR MENDONÇA SICA destaca como função primordial da preclusão impulsionar o processo, tanto que utiliza esse argumento para rechaçar a existência da preclusão consumativa, que parece não ter a mesma finalidade: "Ademais, está absolutamente assentada na mente dos estudiosos a idéia de que a preclusão é instrumento que tem por objetivo regular a celeridade do desenvolvimento processual, seja provocando a marcha adiante, seja impedindo seu retrocesso. Ora, a preclusão consumativa não se encaixa perfeitamente nesse conceito, como a preclusão temporal ou lógica, sobretudo porque desconsidera que a parte, ao adiantar-se e praticar um ato, contribuiu para a celeridade processual, e por isso não pode ser punida" (Preclusão processual civil, pp. 134-135). E ainda, destacando a função da preclusão de impulsionar o processo e assim conferir a ele efetividade, $c f$. RAQUEL MARIANO DA Rocha, Preclusão no processo civil, p. 65-69; MANOEl CAETANo FERREIRA FILHO, A preclusão no direito processual civil, pp. 28-29; MAURícIO GIANNICO, A preclusão no direito processual civil brasileiro, pp. 7980; FERNANDo RUBIN, A preclusão na dinâmica do Processo Civil, p. 22-23.

${ }_{520}$ ENRIQUE VALLINES GARCÍA, La preclusión en el proceso civil, p. 103.

${ }^{521}$ RAQUEL MARIANO DA ROCHA, Preclusão no processo civil, p. 72.

${ }^{522}$ ENRIQUe VAlLines GarCÍA, La preclusión en el proceso civil, p. 118; MANOEl CAETANO FerReira FILHO, A preclusão no direito processual civil, p. 29.

${ }_{523}$ HeITOR VITOR MENDONÇA SicA, Preclusão processual civil, p. 150.

524 RaQUel Mariano DA RoCHA, Preclusão no processo civil, pp. 73-75.
} 
Essa relação entre boa-fé, preclusão e venire, por sua vez, não é unânime. Principalmente por partir de premissa diversa quanto ao que seja a boa-fé, há quem sustente que a preclusão lógica não tem semelhanças com o venire contra factum proprium porque aquela é instrumento de direito público, ao passo que este visa a proteger os interesses privados. Desse modo, a preclusão se afastaria da boa-fé porque esta protege interesses privatísticos incompatíveis com os escopos processuais ${ }^{525}$.

Em resumo, portanto, a preclusão age em prol da proteção dos valores da celeridade, efetividade e segurança jurídica, primordialmente. A boa-fé é também um valor reconhecido por alguns, que já são poucos, e ainda, refutada por autores isolados.

Quanto aos efeitos da preclusão e seus limites, é comum a referência doutrinária ao fato de as preclusões gerarem efeitos apenas endoprocessuais, o que significa dizer que as partes têm o exercício de uma posição jurídica processual limitada apenas em uma mesma sede processual, da mesma forma que a impossibilidade de reapreaciação de determinada questão se limita ao mesmo processo em que já apreciada, sendo livre posterior apreciação em outro processo ${ }^{526}$.

Interessa-nos averiguar os motivos dessa limitação da eficácia às fronteiras do processo. Afinal, por que a preclusão não poderia produzir efeitos também para fora do processo?

O principal motivo identificado decorre da necessária coerência do sistema processual, que não quis atribuir a imutabilidade da coisa julgada material às questões decididas, mas apenas ao dispositivo da sentença (art. 469 do CPC). Assim, se as próprias questões de mérito decididas na fundamentação da sentença não são imutabilizadas pela

\footnotetext{
525 Exemplo dessa distinção entre preclusão é boa-fé é o pensamento de ENRIQUE VALLINES GARCÍA: "De otro, la preclusión por conducta lógicamente incompatible con una conducta procesal suya anterior, puede contribuir a salvaguardar la confianza de otros sujetos en un comportamiento coherente por parte de aquél. Pero esto sería únicamente - si se permite la expresión - un 'efecto reflejo' de la preclusión, pero no su verdadero fundamento. La preclusión no protege un interés privado de quien espera de buena fe un comportamiento coherente por parte de otro; la preclusión responde primordialmente a unos intereses que trascienden lo privado, pues con ella se otorga seguridad no sólo a los judiciables sino también a los tribunales, lo cual redunda en beneficio de una más eficaz administración de justicia . Este último rasgo de la preclusión - aplicado también a la preclusión por conducta lógicamente incompatible - explicaría que ésta opere también en los casos en que la buena fe de un sujeto no se pone en cuestión" (La preclusión en el proceso civil, pp. 253-254).

${ }^{526}$ Humberto TheOdORO JÚNIOR, A preclusão no processo civil, p. 25-26; ANTONIO Alberto Alves BARBosA, Da preclusão processual civil, p. 174-176; FERNANDO RUBIN, A preclusão na dinâmica do Processo Civil, p. 97; CHIOvENDA já identificara esse fenômeno, afirmando que a preclusão se limita às barreiras endoprocessuais pela própria finalidade do instituto, que visa a "rendere certo, ordinato e preciso il cammino del processo" (Cosa giudicata e preclusione), p. 236.
} 
coisa julgada material, incoerente seria que as interlocutórias apresentassem tal qualidade $^{527}$.

Um exemplo ilustrativo dessa ideia: "A" promove uma demanda condenatória em face de "B", visando à cobrança da primeira parcela de um contrato de trato sucessivo firmado entre as partes. "B" alega a nulidade do contrato, tese que é afastada na fundamentação pelo juízo, sendo a demanda ao final julgada procedente. Sabemos que, no nosso atual sistema, se "A" ingressasse com uma demanda em face de "B" visando à cobrança de outra parcela desse mesmo contrato, "B" poderia novamente alegar a invalidade do contrato e o juiz deveria enfrentar mais uma vez o tema, não havendo o efeito positivo da coisa julgada porque coisa julgada não há sobre a fundamentação. Assim, diz-se que, por coerência, nada deve impedir que questões incidentais já enfrentadas no primeiro processo sejam reanalisadas no segundo processo - como pedido de justiça gratuita, a alegação já afastada de ilegitimidade passiva de "B", o cabimento de uma intervenção de terceiro, etc.

Outro motivo identificado estaria ligado ao conteúdo das decisões, ou seja, é decorrente de se considerar que a solução de questões incidentais tem geralmente natureza processual, e dizem respeito apenas àquela relação jurídica processual sub judice. Assim, decidir pela presença ou não de condições da ação, pressupostos processuais ou pelas atividades instrutórias é relevante apenas para aquele determinado processo, sem interesse de extensão de seus efeitos para outros processos que possuam relações jurídicas processuais diversas $^{528}$.

Por fim, argumenta-se que a ausência de norma legal expressa que preveja eficácia panprocessual às questões analisadas no curso do processo não pode ser ignorada $^{529}$, pois, se assim for, corre-se o risco de as partes serem surpreendidas quanto à expectativa de que determinada decisão produzisse efeitos de maneira endoprocessual, $\operatorname{apenas}^{530}$.

Parece-nos que a limitação dos efeitos da preclusão às barrerias do processo em que observada é coerente com a principal finalidade atribuída à preclusão, que é a de impulsionar a marcha processual. Sendo essa a principal preocupação do instituto, basta

\footnotetext{
${ }^{527}$ HeITOR VITOR MENDONÇA SICA, Preclusão processual civil, p. 201.

528 BARbosa Moreira, Questões prejudiciais e coisa julgada, p. 125; HeITOR VITOR MeNDONÇA SiCA, Preclusão processual civil, p. 202.

${ }^{529}$ BARBOSA MOREIRA, Questões prejudiciais e coisa julgada, pp. 123-125.

${ }^{530}$ HeITOR Vitor MENDONÇA SiCA, Preclusão processual civil, p. 203.
} 
que a impossibilidade de exercer a posição jurídica processual se limite a um mesmo processo, o que per si já garante a continuidade dele.

Analisados de maneira unificada os temas relativos ao conceito, natureza jurídica, finalidade e extensão dos efeitos da preclusão, passa-se ao estudo das peculiaridades que fazem com que o fenômeno da preclusão para as partes e para o juiz seja tão distinto.

\subsection{Preclusão para as partes}

A primeira premissa a ser estabelecida com relação à preclusão das posições processuais das partes está no fato de ela incidir sobre ônus processuais, e não sobre faculdades.

Ao tratar sempre da preclusão como "a perda de uma faculdade processual"531, CHIOVENDA parece se referir somente à preclusão voltada às partes, de modo a sempre fulminar o exercício de suas faculdades. Isso, contudo, não é verdadeiro, seja porque, como já exposto, ele também tratou da preclusão de questões, seja porque, mesmo com relação à preclusão das posições jurídicas processuais das partes, a doutrina acertadamente evoluiu para firmar entendimento segundo o qual a preclusão incide sobre ônus e não sobre faculdades propriamente ditas ${ }^{532}$.

Considerando o conceito de faculdade processual - posição jurídica cujo não exercício não implica uma desvantagem -, bem como diante da realidade de que a preclusão gera desvantagem ao sujeito, que se vê limitado da possibilidade de praticar determinados atos processuais, logo se vê que a preclusão não pode ser consequência atribuída à faculdade, porquanto incompatível com o próprio conceito dela. Já considerando que o ônus processual é um imperativo de próprio interesse que, uma vez não praticado, gera uma desvantagem, essa desvantagem é justamente a preclusão, ou seja, a perda definitiva da possibilidade de praticar o ato processual.

O ônus existe na medida em que, de sua inobservância, surge uma desvantagem consistente na perda da possibilidade de exercer determinado ato no processo. Uma vez inexistente essa consequência negativa, não há que se falar mais em

${ }^{531}$ ChIOvENDA, Cosa giudicata e preclusione, p. 232.

${ }^{532}$ HeITOR VitOR MENDONÇA SiCA, Preclusão processual civil, pp. 99-102. 
ônus, e sim em faculdade processual. Daí ser correto afirmar que "só existe ônus se houver preclusão" ${ }^{, 533}$.

Também desde CHIOVEndA ${ }^{534}$ é comum a reprodução na doutrina da classificação da preclusão das partes conforme suas três diferentes modalidades: preclusão temporal, lógica e consumativa, conforme os diferentes fatos geradores que as originam ${ }^{535}$. Ou seja, são espécies representativas de uma perda da possibilidade de praticar um ato processual por motivos distintos, seja porque não foi praticado em momento oportuno (preclusão temporal), seja porque já praticado ato anterior incompatível (preclusão lógica) ou porque o mesmo ato já fora praticado (preclusão consumativa) ${ }^{536}$.

Dentre tais modalidades, a menos problemática é a da preclusão temporal: a perda da possibilidade de praticar um ato processual advém de ter transcorrido o prazo previsto em lei para tanto, ou a fase processual que ele poderia ser exercido. Assim, uma vez exercido o ônus a destempo, o ato é ineficaz por não preencher o seu requisito temporal de admissibilidade, e passa a ser encarado como se jamais fora praticado, tal como uma omissão ${ }^{537}$.

A preclusão temporal exerce papel fundamental na sistemática processual. Por meio da imposição de prazos para a prática dos atos processuais, os quais, uma vez inobservados, culminam na impossibilidade desses atos serem exercidos, é que se garante com mais eficiência a marcha processual, o andar para frente, e, assim, a proteção dos valores da celeridade e efetividade.

\footnotetext{
${ }^{533}$ HeITOR Vitor MENDONÇA SicA, Preclusão processual civil, p. 101. O autor faz a ressalva de que outros efeitos, além da preclusão, podem ser verificados quando a parte deixa de se desincumbir de seus ônus, tal como, por exemplo, observa-se quando se deixa de impugnar especificamente as alegações do autor, que passam a ser presumidamente verdadeiras. Todavia, outros efeitos estarão sempre associados à preclusão, vez que, se inexistente essa, o ato poderia ser repraticado de modo a evitar a incidência de todas as outras consequências. Daí a imprescindibilidade da ligação entre ônus e preclusão (Preclusão processual civil, pp. 154-156).

${ }^{534}$ Nas palavras do autor: “...io intendo per preclusione la perdita o estionzione, o consumazione d'una facoltà processuale che si subisce per il fatto: a) o di nona ver osservato l'ordine assegnato dalla legge al suo esercizio (...); b) o di aver compiuto un'attività incompatibile col'esercizio della facoltà (...); c) o di avere già uma volta validamente esercitato la facoltà (consumazione propriamente detta)" (Cosa giudicata $e$ preclusione, p. 233).

${ }_{535}$ FrEDIE DIDIER JR. e PEDRo NOGUEIRA, Teoria dos fatos juridicos processuais, p. 161.

${ }^{536}$ FREDIE Didier JR. e PEDRo NogUeIRA destacam, ainda, a preclusão cujo fato gerador é um ilícito processual, ou seja, a consequência pelo descumprimento de um dever, gerando assim a modalidade de preclusão-sanção (Teoria dos fatos jurídicos processuais, pp. 167-168).

${ }^{537}$ Heitor Vitor MENDONÇA SicA, Preclusão processual civil, p. 128.
} 
Já a preclusão consumativa é alvo constante de críticas, partindo-se da concepção de CHIOVENDA de que essa preclusão ocorre quando praticado validamente o ato.

De um lado, sustenta-se que a preclusão consumativa se dá independentemente de o ato ter sido praticado válida ou invalidamente ${ }^{538}$, pois o que importa é a consumação e a necessária vedação ao bis in idem. Dessa forma, exercido um ônus processual, isso basta para que ele não possa exercido novamente, ainda que esse "novamente" signifique à semelhança da prática do ônus anterior, porém alterando um dado que o tenha tornado viciado. Essa corrente, todavia, pouco revela os motivos pelos quais a prática de um ato viciado permite considerá-lo como consumado.

Para nós, porém, uma vez praticado o ato viciado, ou seja, em desconformidade com o modelo legal estipulado, não é possível considerar que houve consumação propriamente dita. Afinal, sua desconformidade gera ineficácia do ato, tal como se nunca houvesse sido praticado ${ }^{539}$. Consequentemente, uma vez desconsiderada sua prática pelo próprio sistema, no tocante aos efeitos, nada impede que ele seja exercido de maneira válida, sem a necessidade de se prevenir o bis in idem.

Da mesma maneira, mesmo quando praticado validamente o ato, é despropositado vedar sua complementação dentro do prazo para seu exercício, tal como se o sistema estivesse punindo aquele que exerceu conduta em favor da celeridade, ou seja, antes do prazo limite que lhe fora concedido. Não há norma expressa ou razão jurídica que fundamente a impossibilidade de correção daquele ato já praticado, porém sem que tenha transcorrido o prazo final para seu exercício.

É por isso que se defende a desnecessariedade da classificação autônoma da preclusão consumativa, bastando a existência da preclusão lógica e temporal para explicar os motivos pelos quais as partes perdem posições jurídicas ativas no processo $^{540}$.

Afinal, pretendendo-se praticar um ato processual exatamente igual ao ato anteriormente já praticado, seria o caso de ausência de interesse processual, e não de preclusão consumativa: um ato idêntico a outro já praticado sequer traria repercussões no

\footnotetext{
${ }^{538}$ MAURí́cIO GIANNICO, A preclusão no direito processual civil brasileiro, pp. 52-54; RAQUEL MARIANO DA Rocha, Preclusão no processo civil, p. 83.

${ }^{539}$ HeItor VItOR MENDONÇA SiCA, Preclusão processual civil, p. 123. Como exemplo, o autor faz menção à apelação interposta sem preparo. Uma vez não corrigido o vício, o ato é ineficaz, tal como se nunca houvesse sido praticado.

${ }^{540}$ FERnADO CAIS, Preclusão e a instrumentalidade do processo, pp. 52-62; HeItOR VITOR MENDONÇA SICA, Preclusão processual civil, pp. 151-154.
} 
mundo jurídico ${ }^{541}$. Se, todavia, a pretensão não é praticar ato idêntico, mas apenas semelhante, corrigindo-se o vício existente no primeiro ato ou complementando-o, o ordenamento processual não veda tal possibilidade ${ }^{542}$. Veda-se, todavia, se passado o prazo e o vício deixar de ser reparado, caso em que a perda da possibilidade se dá pela preclusão temporal, e não consumativa ${ }^{543}$.

Em outras palavras, a preclusão temporal parece trazer em si segurança jurídica suficiente às partes, aceitando-se que, antes de findo o termo final para a prática de um ato, ele pode ser retificado sem vedações, o que não feriria qualquer tipo de expectativa no processo diante da prévia ciência das partes quanto à possibilidade de alterações, seguras de que isso não se dará de maneira indefinida, mas apenas dentro de um prazo considerado adequado pelo legislador.

Com relação à preclusão lógica, o instituto é responsável por obstar a prática de um ato processual se outro incompatível com ele fora anteriormente praticado. São exemplos recorrentes na doutrina (i) a impossibilidade da parte que opôs exceção de incompetência suscitar conflito de competência (art. 117 do CPC) e (ii) a impossibilidade de a parte recorrer de decisão que acabou por aceitar expressa ou tacitamente, por meio da prática de ato incompatível com o de recorrer, tal como adimplir espontaneamente a condenação (art. 503 do CPC).

Encontra-se, dentre os poucos que trataram com profundidade do tema da preclusão lógica, alguma divergência quanto à possibilidade de ela existir para além das hipóteses previstas em lei.

Para ENRIQUE VALLINES GARCÍA, por exemplo, trata-se de questão difícil, vez que, em favor dessa admissibilidade que transborda os casos legais, pode-se argumentar que a lógica é elemento informativo de todo o ordenamento jurídico e que existe uma ideia geral que veda as condutas incompatíveis do ponto de vista lógico em toda a vida jurídica.

\footnotetext{
541 ENRIQUE VALLINES GARCÍA também afasta a preclusão consumativa como verdadeira hipótese de preclusão. Porém, fa-lo partindo da premissa de que as preclusões são a consequência do não exercício de um poder processual, de modo que o efetivo exercício gera o fenômeno que denominou de "agotamiento" ou "consumación" (La preclusión en el proceso civil, pp.47-48).

${ }^{542}$ Apesar de não defender a eliminação da preclusão consumativa, HUMBERTO THEODORO JÚNIOR vislumbra que sua finalidade não era impedir a correção de ato defeituoso: "Fenômeno diverso da reiteração do ato consumado é a sua correção, quando tenham ocorrido deficiências na forma ou conteúdo. A preclusão impede a reiteração da prática do mesmo ato, mas não a retificação de erros ou suprimento de falhas" ( $A$ Preclusão no processo civil, p. 15).

${ }^{543}$ Heitor Vitor MendonÇa SiCA, Preclusão processual civil, p. 154. Fernando CAIs, Preclusão e a instrumentalidade do processo, pp. 51-52.
} 
Entretanto, também não faltam razões para interpretar a preclusão lógica dentro da estrita legalidade, optando o autor por essa segunda corrente porque (i) o sistema admite contradições simultâneas - basta pensar, v.g., na regra da eventualidade; (ii) traria insegurança jurídica às partes fazer com que haja perda de posições processuais sem regra legal genérica e expressa que assim estabeleça; (iii) a jurisprudencia identifica poucos casos de preclusão lógica, e que poderiam ser resolvidos por outro tipo de preclusão. Conclui, dessa maneira, só existem as preclusões lógicas previstas em lei; os demais casos de contradição são permitidos pelo sistema processual ${ }^{544}$.

Na doutrina brasileira, porém, prevalece que os casos de preclusão lógica não estão adstritos às exemplificações legais ${ }^{545}$, sendo citados outros exemplos, como o de apresentar confissão de um fato posteriormente refutado. Isso permite afirmarmos a impossibilidade de descrever um rol taxativo sobre as hipóteses de preclusão lógica, cuja identificação demanda uma análise do caso concreto e da incompatibilidade entre as ações praticadas.

Há igualmente poucos autores que enfrentam a possibilidade de a preclusão lógica se dar a partir de um comportamento praticado fora do processo, mas que nele seja posteriormente noticiado pela alegação das partes ${ }^{546}$.

Os exemplos dados pela doutrina ${ }^{547}$ ou reconhecidos pela jurisprudência ${ }^{548}$, por sua vez, fazem com que implicitamente entendamos que as condutas em contradição

\footnotetext{
${ }^{544}$ ENRIQUE VALLINES GARCíA, La preclusión en el proceso civil, pp. 254-255. Na verdade, para ser bastante fiel às ideias do autor, ele primeiramente divide as condutas entre contraditórias e contrárias ("la contradicción y la contrariedad"). As primeiras seriam aquelas em que uma conduta é a total negação da outra, ao passo que as segundas se caraterizam por tratar de condutas opostas sem que uma seja negação da outra, o que nos permite concluir que esse segundo caso é caracterizado por uma necessária atividade interpretativa para depreender a contradição existente. E conclui o autor que as condutas contraditórias são vedadas pelo sistema a despeito de lei expressa assim afirmando, em atenção ao princípio da não contradição. Para tanto, exemplifica que "reconocer expresamente un documento e impugnarlo son conductas absolutamente contradictorias que no pueden coexistir, ni siquiera por la vía de la acumulación eventual" ( $\mathrm{La}$ preclusión en el proceso civil, p. 259). Já as condutas contrárias, para o autor, não podem ser reprimidas sem previsão legal anterior: "A pesar de todo lo anterior, consideramos que de lege data, debe rechazarse la existencia de una preclusión basada exclusivamente en la contrariedad lógica. Especial peso tiene en esta opinión el hecho de que el legislador no establezca esa preclusión de manera clara y explícita. Y es que, como afirmamos supra, la seguridad jurídica impone que el justiciable pueda encontrar en el ordenamiento jurídico elementos suficientes para conocer de antemano qué condudctas suyas van a tener efectos extintivos respecto de sus derechos y faculdades, lo cual no acontece en los casos en los que se afirma la preclusión de poderes por práctica de conductas lógicamente contrarias" (La preclusión en el proceso civil, p. 265).

${ }_{545}$ HeITOR VITOR MENDONÇA SicA, Preclusão processual civil, p. 149 e 161.

${ }^{546}$ Ao definir a noção de preclusão lógica para a doutrina, ENRIQUE GARCÍA afirma: "Así pues, en la medida en que la conducta se observa en un proceso, es en ese proceso donde puede llegar a producirse automáticamente la extinción de los poderes procesales incompatibles - que no se llegan a utilizar - lo cual nos permite calificarla (a esta extinción) de preclusión. En resumen: la observância de determinadas conductas en el seno de un proceso puede traer consigo la instantánea preclusión de poderes procesales cuyo ejercicio resulte incompatible con esas conductas" (La preclusión en el proceso civil, p. 248).
} 
são aquelas comumente praticadas dentro de um mesmo processo, mas sem que tenhamos identificado, no âmbito da doutrina brasileira, uma vedação à configuração da preclusão lógica a partir de condutas praticadas em processos distintos ou até mesmo fora de qualquer sede processual.

A preclusão lógica é afastada quando a incompatibilidade é permitida pelo ordenamento, como no caso da aplicação da regra da eventualidade. Além disso, nega-se a aplicabilidade da preclusão lógica em casos de ato omissivo, mas apenas em casos de incompatibilidade entre atos comissivos ${ }^{549}$.

Por fim, conforme já adiantado no item 4.3. supra, no que se refere à preclusão para as partes, sendo a preclusão a consequência de um fato ou ato jurídico processual, sua repercussão prática consiste na perda do direito de praticar determinado ato no mesmo processo $^{550}$, o que implica considerar ineficaz o ônus processual exercido de maneira preclusa, na incapacidade de produção dos efeitos desejados pelo exercício de ônus precluso e, portanto, na inadmissibilidade dessa conduta.

\subsection{Preclusão para o juiz}

\subsubsection{Esclarecimentos terminológicos}

Como esclarecimento conceitual inicial, destaca-se que muitos doutrinadores tratam como sinônimas as expressões "preclusão para o juiz" e "preclusão pro iudicato". Todavia, essa segunda não foi criada com o intuito de retratar as hipóteses de perda do

\footnotetext{
${ }^{547}$ São exemplos de DANIEL AMORIM ASSUMPÇÃo NEVES (i) o pagamento voluntário e a interposição de recurso; (ii) purga da mora e apresentação de contestação em ação de despejo; (iii) pedido de julgamento antecipado e posterior pretensão à instrução probatória; (iv) desinteresse na conciliação e posterior transação (Preclusões para o juiz, pp. 36-38). FERNANDO RUBIN indica (v) impossibilidade de o autor opor exceção de incompetência, já que ele mesmo escolheu o foro e (vi) impossibilidade do réu que apresentou defesa nomear a autoria posteriormente (A preclusão na dinâmica do Processo Civil, pp. 119-120).

${ }^{548}$ Como exemplos da jurisprudência, destaca-se: (i) pagamento dos valores considerados devidos e posterior interposição de recurso (AgRg no AREsp 399.070/ES, Rel. Ministro ARI PARGENDLER, PRIMEIRA TURMA, julgado em 11/03/2014, DJe 19/03/2014); (ii) concordância com cálculos apresentados e posterior insurgência (AgRg no REsp 1330637/RJ, Rel. Ministro CASTRO MEIRA, SEGUNDA TURMA, julgado em 27/11/2012, DJe 06/12/2012); (iii) renúncia do direito de recorrer seguida de interposição de recurso (EDcl no HC 227.658/SP, Rel. Ministra MARIA THEREZA DE ASSIS MOURA, SEXTA TURMA, julgado em 03/05/2012, DJe 14/05/2012), entre tantos outros.

${ }_{549}$ HeITOR VITOR MENDONÇA SicA, Preclusão processual civil, p. 151.

${ }^{550}$ HeITOR Vitor MENDONÇA SicA, Preclusão processual civil, pp. 154-156.
} 
poder do magistrado de reapreciar uma mesma questão já decidida no curso do processo. Sua origem está atrelada à tentativa de REDENTI, processualista italiano, de estender os efeitos de determinadas decisões para além do processo, ou seja, atribuir-lhes efeitos panprocessuais, o que originalmente só se observa quando existente a coisa julgada material sobre os efeitos da decisão de mérito ${ }^{551}$.

Partindo principalmente do estudo da execução de título executivo extrajudicial $^{552}$, REDENTI se atentou para os casos em que o devedor (i) cumpre voluntariamente a obrigação; (ii) deixa de opor embargos à execução; ou (iii) uma vez os opondo, são extintos sem julgamento de mérito, e a execução chega ao final de modo a alcançar a satisfação do crédito. São hipóteses em que há em comum, além da satisfação do crédito, a inexistência de atividade cognitiva quanto à relação jurídica subjacente à existência da dívida.

Nessas situações, em prol da segurança jurídica da atividade que culminou com a satisfação do crédito, deveria incidir também um fenômeno de estabilidade da decisão, semelhante à coisa julgada, mas que com ela não se confunde pela possibilidade de rediscussão entre as mesmas partes e em outros processos, desde que essa rediscussão não implique a devolução do crédito satisfeito ${ }^{553}$.

Apesar dessa distinção, a preclusão pro iudicato foi criada para gerar os mesmos efeitos práticos da coisa julgada material, ou seja, a motivação da teoria foi conferir os efeitos da coisa julgada a hipóteses em que ela não incide ${ }^{554}$.

Considerando os limites da proposta deste trabalho, basta destacar tais ideias para se concluir que a preclusão pro iudicato de REDENTI não tem relação com o fenômeno da preclusão de questões no curso do processo. Não obstante, para aqueles que não viam na doutrina de CHIOVENDA a existência de preclusões para o juiz, buscou-se outro nome

\footnotetext{
${ }^{551}$ DANIEL NeVES, Preclusões para o juiz, p. 20. Sobre a confusão da nomenclatura feita pela doutrina, $c f$. ainda, ALEXANDRE BARROSO, Acesso à justiça e preclusão civil, pp. 113-116.

${ }^{552} \mathrm{O}$ autor italiano também vislumbrou o fenômeno da preclusão pro iudicato quando ausentes os embargos no processo monitório, como esclarece DANIEL NEVES, Preclusões para o juiz, p. 22.

${ }^{553}$ Nas palavras de REDENTI, se na execução de título extrajudicial "la opposizione non vi sia e l'esecuzione giunga industurbata fino al suo termine, questo rappresenterà egualmente qualche cosa di irrevocabile e di irreparabile. Dal questo momento nessuno potrà più insorgere contro il fatto compiuto per distruggerlo od infirmalo. $\mathrm{E}$ in tali limiti si avrà un risultato pratico, simile a quello che si avrebbe, se fosse comperto dal giudicato. Si può parlare pertanto inquesti casi de preclusione pro iudicato. E il fatto compiuto avrà le consuete conseguenze riflesse anche per i terzi. La differeza rispetto ai provvedimenti di accertamento è la seguente: che il diritto non accertato potrà esser rimesso in questione anche fre le parti, quante volte ciò possa avvenire senza intaccare il risultado pratico ottenuto coi provvidimenti anteriori." (Diritto Processuale Civile, v. I, p. 80).

${ }^{554}$ DANIEL NEVES, Preclusões para o juiz, p. 22.
} 
para o fenômeno, adotando-se, sem precisões conceituais, a preclusão pro iudicato ${ }^{555}$. E a mesma referência às preclusões para o juiz como sinônimo de preclusão pro iudicato passou a ser comumente reproduzida na doutrina ${ }^{556} \mathrm{e}$, principalmente, é constantemente mencionada na jurisprudência ${ }^{557}$.

Visando a acabar com a confusão e assim privilegiar a correta aplicação da preclusão concernente às questões incidentais já decididas no curso do processo, a recente doutrina vem tentando alterar a tradição da utilização do termo preclusão pro iudicato. Assim é que DANIEL NEVES sugere o uso do termo "preclusão judicial" forma, Fredie Didier JR. e PEDRo NoGUEIRA apontam também a expressão “preclusão para o juiz" ${ }^{, 59}$, termo que ora se adota com mais frequência pela clareza por ele traduzida, sendo quase intuitivo o fenômeno a que se refere ${ }^{560}$.

\subsubsection{O conceito de preclusão para o juiz}

A preclusão para o juiz pode ser definida de maneira bastante simples e objetiva como a impossibilidade de reapreciar questões já decididas incidentalmente no curso do processo.

O conceito de questão não deve se limitar à ideia de CARNELUTTI como ponto controvertido entre as partes ${ }^{561}$, pois não necessariamente o juiz dependerá da controvérsia

\footnotetext{
555 Nesse sentido são as afirmações de JOSÉ FREDERICO MARQUES, que entende que "a preclusão consumativa é fato que resulta de ato decisório irrevogável. Quando a decisão é sentença sobre o mérito, essa preclusão, dentro do processo, tem o nome de coisa julgada formal (...). Se a decisão, no entando, tiver conteúdo apenas processual, haverá preclusão pro iudicato" (Manual de Direito Processual Civil, v. II, pp. 179-180).

${ }^{556}$ Humberto TheOdORO JÚNior, A preclusão no processo civil, p. 19; JOÃo BATISTA LOPES, Breves considerações sobre o instituto da preclusão, p. 17.

${ }^{557}$ Nesse sentido, por exemplo, $c f$. os seguintes julgados do Superior Tribunal de Justiça: AgRg no RMS 36.522/RS, Rel. Ministro HERMAN BENJAMIN, SEGUNDA TURMA, julgado em 22/05/2012, DJe 15/06/2012; AgRg na MC 15.637/SP, Rel. Ministro MASSAMI UYEDA, TERCEIRA TURMA, julgado em 18/08/2009, DJe 31/08/2009; REsp 713.243/RS, Rel. Ministro LUIZ FUX, PRIMEIRA TURMA, julgado em 11/04/2006, DJ 28/04/2006, p. 270.

558 "É justamente a mudança da expressão que caracteriza essa impossibilidade de o juiz voltar atrás em suas decisões a qual pretendemos não mais chamar preclusão pro iudicato, mas sim de preclusão judicial" (DANIEL NEVES, Preclusões para o juiz, p. 25).

${ }^{559}$ FREDIE DIDIER JR. e PEDRO NOGUEIRA. Teoria dos fatos jurídicos processuais, p. 174.

560 Há, ainda, outras possibilidades sugeridas pela doutrina, v.g. "preclusão de questões" (MAURícIO GIANNICO, A preclusão no direito processual civil brasileiro, p. 133).

${ }^{561}$ A doutrina comumente aponta a definição de CARNELUTTI de questão como ponto controvertido de fato e de direito ( $c f$. entendimento de CÂNDIDO DINAMARCO sobre as ideias de CARNELUTTI: Nova era do processo
} 
entre as partes para analisar uma determinada circunstância jurídica relevante para o processo, assim como não depende da alegação das partes. Exemplo disso são as questões que podem ser conhecidas de ofício, sejam de cunho processual ou de direito material, bem como as matérias que podem ser enfretadas e decididas contrariamente ao que ambas as partes desejam - ou seja, sem que haja controvérsias.

Assim, ao nos referirmos à preclusão para o juiz como sendo a impossibilidade de rediscutir questões, entendam-se essas como um conceito bastante amplo, que abarque qualquer dúvida, seja apontada pelas partes, seja identificada pelo juiz, e que seja dirimida no curso do processo ${ }^{562}$. E pelo termo “incidentalmente", entendam-se as questões enfrentadas no curso processo ou mesmo na sentença, desde que, pelo seu conteúdo, sejam etapas a serem vencidas para que se chegue à apreciação do mérito. Assim, o caráter incidental não se extrai do momento em que apreciadas, vez que na própria sentença são resolvidas questões - assim como, no curso do processo, é possível que o mérito seja parcialmente resolvido. O importante é se atentar para o seu conteúdo que representa um entrave, uma etapa a ser vencida para o julgamento do mérito ${ }^{563}$.

\subsubsection{Questões e seus elementos identificadores}

Ao entendermos por preclusão para o juiz a impossibilidade de reapreciar questões, é preciso definir quando identificamos duas ou mais questões como sendo idênticas, ou seja, quais são os elementos identificadores de uma questão - só identificando-as será possível fazer incidir a preclusão, vedando a apreciação da mesma questão.

civil, p. 286; Egas DiRCEu Moniz DE ARAgão, Preclusão, p. 172) e, nesse caso, a definição ora apresentada de questão seria mais ampla do que aquela construída pelo autor italiano.

${ }^{562}$ Heitor VITOR MendonÇa SICA, Preclusão processual civil, p. 154. Nesse sentido, destaca-se o pensamento de KAZUO WATANABE sobre o tema: “Ao longo do iter lógico em direção ao provimento final, o juiz deve conhecer de todos os pontos relevantes, de direito e de fato, alegados pelas partes, mesmo que permaneçam eles incontroversos, e, além de conhecer, tambem resolver as questões de fato e de direito, em que se convertem os pontos controvertidos pelas partes ou em relação aos quais alimente qualquer dúvida" (Cognição no processo civil, p. 113).

${ }_{563}$ Aqui se adota o clássico conceito de mérito equivalente ao objeto litigioso do processo, ou, nas palavras de CÂNDIDO DINAMARCo, "o vocábulo mérito, de uso corrente e empregado muitas vezes no Código de Processo Civil, expressa o próprio objeto do processo. A pretensão ajuizada, que em relação ao processo é seu objeto, constitui o mérito das diversas espécies de processos" (Instituições de direito processual civil, v. II, p. 187). 
O tema parece ser um dos mais simples, tanto que, pela pouca controvérsia, são raros os comentários da doutrina sobre o tema, qual seja, sobre os elementos identificadores da questão incidental apreciada, a fim de que, uma vez identificada, seja possível se falar em preclusão para o juiz. Não obstante a pouca atenção que esse ponto recebe da doutrina ${ }^{564}$, entendemos se tratar de fator crucial para a compreensão e, principalmente, para a aplicação do instituto das preclusões para o juiz.

Tal como a demanda, que possui três elementos identificadores - partes, causa de pedir e pedido ${ }^{565}$-, as questões incidentais também têm elementos sem os quais sua identificação deixa de existir; são eles: (i) o mesmo ponto de fato ou de direito, (ii) o mesmo suporte fático-jurídico e (iii) o mesmo suporte probatório ${ }^{566}$.

A necessidade de se tratar de um mesmo ponto de fato ou de direito é quase intuitiva: alterando-se o ponto sobre o qual paira a dúvida, altera-se a matéria de cognição do juiz que, portanto, deixa de estar vinculado a decisões anteriores, pois se está diante de uma nova questão, ainda não apreciada.

O segundo elemento de identificação consiste nas razões fáticas consideradas quando da apreciação da questão, ou seja, o suporte fático trazido pelas partes e considerado pelo juiz para apreciação da questão ${ }^{567}$. Como exemplo, pode-se citar o caso de decisão que indeferiu o pedido de assistência jurídica gratuita pleiteado, em um primeiro momento, apenas sob a alegação de que a requerente exercia profissão que proporcionava poucos rendimentos - e o juízo considerou, por exemplo, que o salário permitia o pagamento das custas judicias sem sacrifício do sustento da família. Se, posteriormente, pede-se a mesma assistência gratuita, dessa vez sob alegação de que houve perda do emprego, altera-se o suporte fático e a questão pode ser reapreciada, ou melhor, pode ser apreciada a nova questão.

\footnotetext{
${ }^{564}$ Em verdade, de todas as obras lidas para a elaboração deste trabalho, apenas HEITOR VITOR MENDONÇA SICA desenvolveu o tema. E também este autor não citou mais ninguém. Por isso, o diálogo que ora se estabelece tem por base somente as observações do autor.

${ }^{565}$ CÂNDIDO DINAMARCO, Instituições de direito processual civil, v. II, p. 117.

${ }^{566}$ HeITOR Vitor MENDONÇA SICA, Preclusão processual civil, p. 199. A inserção da palavra "jurídico" no termo "fático-jurídico" é nossa.

${ }^{567}$ Nas exatas palavras de HeITOR VITOR MENDONÇA SiCA: “Além disso, só existiria identidade entre uma e outra questão se o suporte fático que embasou ambos for idêntico. Mudadas as condições sob as quais se assentou a anterior decisão, e reproposto o mesmo ponto de fato ou de direito, não se cogita de preclusão para o juiz. Essa tese encontra apoio no próprio art. 462 do CPC, que regra a influência do fato superveniente no processo e se extrairia também de uma interpretação do art. 471, I, do CPC, que afasta os efeitos da coisa julgada quando há alterações fáticas ou jurídicas com respeito a relações que se prolongam no tempo." (Preclusão processual civil, p. 199).
} 
Mas será que a alteração do suporte jurídico não influencia na identificação das mesmas questões? E, ao se mencionar a expressão "alteração do suporte jurídico", não nos referimos às novas alegações de direito fundadas em leis já existentes no ordenamento e que já poderiam ter sido feitas pelas partes, bem como a consideração de ofício pelo juiz de leis que antes ignorava, mas que já existiam no sistema. Trata-se de alteração do suporte jurídico decorrente de alteração legislativa sobre matéria no curso da demanda.

Nessas hipóteses, entendemos possível a reapreciação da questão ou, melhor dizendo, a apreciação de nova questão, pois a lei superveniente acaba por influenciar nos seus elementos identificadores, fazendo surgir uma nova questão no curso do processo. Daí ser sugerido que o segundo elemento identificador (suporte fático) seja estendido para abarcar também o suporte jurídico existente no ordenamento quando da apreciação da decisão.

A partir disso, tendemos a discordar das conclusões de MONIZ DE ARAGÃO a respeito da influência da lei interpretativa superveniente com relação a questões já decididas. Segundo o autor, a preclusão obsta a incidência da norma interpretativa promulgada de maneira superveniente à apreciação de uma questão, "não por se tratar de coisa julgada, que não existe, e sim por se tratar de atos jurídicos perfeitos, igualmente protegidos pela norma constitucional" ${ }^{568}$.

Em nossa visão, alterando-se o diploma legal sobre o tema, sendo superveniente uma lei que incida sobre uma questão já decidida no curso do processo, não há impedimentos para que ela seja reapreciada ${ }^{569}$. Isso porque, com a lei superveniente, altera-se o próprio suporte jurídico da questão, alterando-se, assim, a própria questão, uma vez modificado um de seus elementos identificadores. Desse modo, a nova apreciação não fere o ato jurídico perfeito, vez que se estaria diante de um novo ato ${ }^{570}$.

Como exemplo, podemos imaginar um processo no qual, como questão incidental, já fora decidida a possibilidade de penhora de um bem, vez que, apesar de ser bem de família, a execução decorre de contrato de fiança acessório ao de locação e, como é

\footnotetext{
${ }^{568}$ Preclusão, p. 166.

569 De maneira superficial, destacamos que também a estabilização da demanda não é um impedimento, já que a superveniência de fatos novos já é admitida como exceção à estabilização pelo sistema (art. 462 e art. 517 do CPC), o que pode ser estendido a novas leis.

${ }^{570}$ FERNANDO RUBIN apresenta interpretação intermediária, defendendo uma articulação entre os valores da efetividade e da segurança jurídica, de modo a permitir a reapreciação de questão que venha a ser influenciada por lei superveniente se o tema for de ordem pública, apenas (A preclusão na dinâmica do processo civil, p. 81).
} 
cediço, a impenhorabilidade do bem de família não se aplica nessa hipótese. Se, porventura, é editada uma lei no curso da execução - sem que ainda tenha havido alienação do bem penhorado -, cuja finalidade é interpretar os artigos $3^{\circ}$, inc. VII, da Lei n. 8.009/90 c.c. art. 82 da Lei de Locações, de modo a deixar claro que a exceção do bem de família se opõe também ao fiador de contrato de locação, nada impediria que a questão fosse reapreciada, pela alteração do embasamento jurídico concernente ao tema ${ }^{571}$.

Com isso, defende-se que a apreciação de uma questão não significa per si a existência de um ato jurídico perfeito, de modo que é formada uma nova questão diante da sobreposição de uma nova lei no curso do processo. Isso, todavia, não se confunde com as consequências no mundo materialístico decorrentes da apreciação da questão sob a vigência de lei anterior. Se, no nosso exemplo, antes da nova lei que tornasse o bem de família do fiador impenhorável já tivessem ocorridos atos de alienação do bem, pode-se argumentar que tais atos são protegidos por serem juridicamente perfeitos porquanto consumados (art. $6^{\circ}, \S 1^{\circ}$ da Lei de Introdução às Normas do Direito Brasileiro), sendo vedada a recomposição ao estado anterior ${ }^{572}$.

Por fim, com relação ao suporte probatório, uma vez modificados os elementos que visam a demonstrar determinada questão já decidida, abre-se caminho para a reapreciação: “de fato, aprofundada a cognição judicial sobre os elementos que conduziram à primeira decisão, não se poderia falar jamais em preclusão para o juiz" ${ }^{„ 573}$.

É o caso de, por exemplo, no que se refere ao pedido de desconsideração da personalidade jurídica, em uma primeira oportunidade ele ter sido negado porque não comprovado o desvio de finalidade. Mas, após a juntada de provas demonstrando o desvio, permite-se a reapreciação, sem que seja possível se falar em preclusão para o juiz.

\footnotetext{
571 CHIOVEnda parece apoiar a influência de lei interpretativa superveniente mesmo sobre questões já preclusas: "al contrario la nuova legge interpretativa prevale sulla semplice preclusione, per la ragione altrettanto semplice che, quando il processo è tuttora pendente e l'operazione dell'aplicazione della legge tuttora aperta, quando insomma la preclusionze non ha ancora spiegato il suo effetto e non è stata alle ultime consequenze, non è ammissibile che il giudice adotti ed applichi una interpretazione di legge diversa da quella impostadalla legge vigente" (Cosa giudicata e preclusione, p. 279).

${ }_{572}$ Parece ter sido esse o entendimento do Superior Tribunal de Justiça quando do advento da Lei $\mathrm{n}$. 8.009/90, ao considerar não serem atos jurídicos perfeitos as penhoras já realizadas, o que culminou na Súmula 205 do STJ: “A Lei n ${ }^{\circ} 8.009-90$ aplica-se à penhora realizada antes de sua vigência”. Porém, uma vez esgotados os atos de execução, era defeso o retorno ao estado anterior, o que se ilustra com o seguinte julgado: "EXECUÇÃO. IMÓVEL RESIDENCIAL. PENHORA EFETIVADA ANTES DA EDIÇÃO DA LEI $N^{\circ}$ 8.009, DE 29.03.90. Não se tendo ainda exaurido a execução pela alienação do bem penhorado, admissível é a incidência da Lei $n^{\circ} 8.009 / 90$ sobre a penhora efetuada antes de sua vigência. Precedentes. Recurso especial conhecido e provido, rejeitada a preliminar. (REsp 175.008/SP, Rel. Ministro BARROS MONTEIRO, QUARTA TURMA, julgado em 03/09/1998, DJ 14/02/2000, p. 36)”.

${ }^{573}$ HeITOR VitOR MENDONÇA SiCA, Preclusão processual civil, p. 199.
} 
Assim, uma vez alterado o ponto de fato ou de direito, o suporte fático-jurídico que embasa uma questão ou o acervo probatório que a alimenta, reconhece-se a existência de uma nova questão, passível, portanto, de reapreciação ${ }^{574}$. Tais constatações são bastante pertinentes inclusive para que os receosos da funcionalidade das preclusões para o juiz no sistema entendam não se tratar de instituto que engessa desnecessariamente o processo, porquanto bastante amplas as possibilidades de alteração dos elementos da questão, permitindo-se, assim, nova apreciação. O que a preclusão para o juiz impede é que haja retrocessos desnecessários e improdutivos no curso do procedimento.

\subsubsection{Fato gerador da preclusão para o juiz}

Importante, para nós, analisar qual o fato gerador que enseja a preclusão para o juiz: seria o transcorrer de um prazo, a consumação de decisão anterior ou a existência de decisão prévia incompatível?

É praticamente unânime na doutrina a afirmação de que ao juiz não se aplica a preclusão temporal $^{575}$, pois os prazos a ele conferidos são impróprios, sem qualquer efeito processual decorrente de sua inobservância. Até porque o juiz tem o poder-dever de atuação, sem que o transcorrer do prazo possa eximi-lo de praticar sua função ${ }^{576}$.

Resta analisar se o fenômeno da preclusão para o juiz se enquadra nas demais categorias de preclusão, quais sejam, a lógica e a consumativa. E, nesse ponto, a doutrina é divergente, existindo defensores de que ambas se aplicam ao juiz ${ }^{577}$, de que somente incide

\footnotetext{
574 "Vale dizer, na superveniência de circunstâncias que alterem os fundamentos da decisão proferida, poderá haver exceção à regra, permitindo novo exame. Porém, neste caso, não estaremos diante do instituto da preclusão consumativa, pois não se trata da reprodução de decisão sobre idêntica situação processual, mas de nova decisão, baseada em circunstâncias temporais e fáticas diversas" (ANTONIO DO PASSO CABRAL, Nulidades no processo moderno, p. 265).

${ }^{575} \mathrm{Em}$ sentido contrário, admitindo casos de preclusão temporal para o juiz: ANTONIO DO PASSO CABRAL, Nulidades no processo moderno, pp. 272-275.

${ }^{576}$ CÂNDIDO DinAmARCO, Instituições de direito processual civil, v. II, p.567. DANIEL Neves, Preclusões para o juiz, p. 41, Fernando CAIS, Preclusão e a instrumentalidade do processo, p. 67; HumBerTo THEODORO JÚNIOR, A preclusão no processo civil, p. 22.

577 Pedro NogueIRa e Fredie Didier JR., Teoria dos fatos jurídicos processuais, p.175; DANIEL NeVes, Preclusões para o juiz, p. 42; SIDNEY PEREIRA DE SOUZA JUNIOR, A preclusão pro iudicato na determinação de provas e a "limitação" do poder instrutório do juiz (art. 130 do CPC), p. 265.
} 
na preclusão consumativa ${ }^{578} \mathrm{e}$, por fim, na de que só existe a preclusão lógica para o juiz $^{579}$.

Já tivemos oportunidade de esclarecer que, com relação à preclusão da atividade das partes, a modalidade consumativa pouco acrescenta, vez que o sistema permite a complementação de ato viciado dentro do prazo legal para a sua prática. Dessa forma, em princípio, bastaria a existência da preclusão lógica e da preclusão temporal no que se refere ao impedimento de exercício de ônus processuais pelas partes (item 7.2 supra).

No que concerne à preclusão para o juiz, porém, parece-nos que a preclusão consumativa é aquela que melhor explica o fenômeno.

Considerando que a classificação entre preclusão lógica e consumativa se funda na causa de que se origina a perda do poder de apreciação da questão pelo juiz, cumpre-nos indagar se a vedação à repareciação de questões é decorrente da impossibilidade de o juiz incorrer em bis in idem, de praticar ato incompatível com o anteriormente praticado, ou de ambas as causas.

Se a finalidade fosse vedar a contradição, apenas, seria possível concluir que o juiz poderá sempre reapreciar a questão, desde que mantenha o seu posicionamento anterior. Assim, a parte insatisfeita com a primeira decisão poderia formular pedidos de reconsideração, e, desde que o juiz mantivesse seu posicionamento, nada impediria a reapreciação, já que a contradição não ocorreria.

Isso significaria admitir a reapreciação de alegações idênticas já suficientemente afastadas no curso do processo, de maneira infindável, o que certamente não corresponde à funcionalidade das preclusões para o juiz no sistema, vez que a marcha processual poderia ser constantemente tumultuada por alegações idênticas, e com relação às quais o juiz poderia se manifestar novamente, desde que não mudasse seu posicionamento. Tal resultado seria absolutamente inútil ao processo, de que se conclui que a preclusão para o juiz não pode se pautar exclusivamente na vedação da contradição como razão de ser.

\footnotetext{
${ }^{578}$ Humberto THEOdORO JÚNIOR, A preclusão no processo civil, p. 19; ANTONIO DO PASSO CABRAL, Nulidades no processo moderno, pp. 263-265; MANOEL CAETANO FERREIRA FILHO, A preclusão no direito processual civil, p. 25.

${ }^{579}$ FERNANDO CAIS, Preclusão e a instrumentalidade do processo, p. 62-70.
} 
Já pela preclusão consumativa, independentemente do resultado a que o juiz chegasse com a reapreciação, ou seja, a despeito de ele optar por uma mudança de posicionamento ou não, a simples reapreciação da mesma questão é vedada, para que não se incorra em bis in idem, o que representaria demora desnecessária ao processo.

E, tendo em vista essa vedação à reapreciação, desnecessário se falar em preclusão lógica para o juiz: antes que ele corra o risco de proferir decisão incompatível com aquela anteriormente proferida, ele simplesmente não pode reapreciar novamente aquela questão, pois a preclusão consumativa incide em momento anterior. Assim, entender a preclusão consumativa como a responsável por vedar a reapreciação de questões pelo juiz torna desnecessário se falar em preclusão lógica, porquanto em momento anterior ao risco da contradição o juiz já perdeu o poder-dever de se manifestar novamente sobre a mesma questão.

Dessa maneira, não é a preclusão lógica, ou a preclusão lógica atrelada à preclusão consumativa, que melhor explicam a preclusão para o juiz; para tanto, basta a preclusão consumativa, que, se para as partes é dispensável - até porque a preclusão temporal assume papel relevante e por si só já faz com que sejam limitadas as posições jurídicas processuais das partes -, é essencial para explicar as preclusões para o juiz.

Uma possível crítica a esse posicionamento está na afirmação de que ao juiz não é vedado simplesmente complementar uma decisão que se mostre incompleta. No exemplo no qual o juiz, ao acolher a exceção de incompetência, esquece-se de mencionar qual o juízo para o qual devem ser remetidos os autos, afirma-se que esclarecer tal ponto não é vedado em nosso ordenamento, motivo por que não existiria a preclusão consumativa para o juiz ${ }^{580}$.

Ocorre que ao simplesmente complementar uma decisão já tomada, não há repareciação de questões propriamente dita, razão pela qual considerar a possibilidade de complementação como exceção à preclusão consumativa nos parece equivocado. É preciso lembrar-se da premissa de que nos utilizamos ao definir que as preclusões incidem sobre as mesmas questões, vedando-se a reanálise. Ao complementar decisões, o juiz não as reaprecia novamente, motivo pelo qual a complementação não é obstada pela preclusão.

É possível, nesse ponto, fazer uma distinção entre complemento necessário e complemento útil de uma decisão. Aquele necessário porquanto imprescindível à

\footnotetext{
${ }^{580}$ FERNANDO CAIS, Preclusão e a instrumentalidade do processo, p. 69.
} 
continuidade do processo - tal como no nosso exemplo da exceção de incompetência - é passível de ser feito pelo juiz sem configurar nova questão. Já aquele complemento útil, porém não imprescindível, só pode ser feito mediante provocação por meio de embargos de declaração.

Na prática forense, haverá alguma dificuldade em distinguir as hipóteses em que a decisão está incompleta e merece simples complementação necessária, ou casos em que houve verdadeira ambiguidade, obscuridade ou omissão, de modo que a correção possa representar verdadeira reapreciação da questão. Se o exemplo supra destacado é um caso de simples complementação, maior dificuldade trará hipotése, v.g., em que o juiz deixa de indicar termo final para condenação de prestações vincendas, ou quando, em sede de concessão da antecipação dos efeitos da tutela, esquece-se de limitar a extensão dela, determinando, por exemplo, a impossibilidade de corte de serviços ou de inscrição do nome do requerente nos órgãos de proteção ao crédito, sem mencionar sob quais circunstâncias.

Não é possível, a priori, vislumbrar todas as possíveis hipóteses de mera correção ou de verdadeira reapreciação, ficando a cargo do intérprete do direito - seja o juiz monocrático ou, em caso de discordância das partes quanto à interpretação por ele conferida, os órgãos colegiados - identificá-las e assim concluir pela existência ou não de preclusão. O importante é se perguntar se, com a correção da incompletude, houve verdadeira reanálise da questão ou mero esclarecimento.

Assim, mantemos a conclusão de que a preclusão para o juiz é fenômeno explicado pela preclusão consumativa ${ }^{581}$. Isso não significa dizer, porém, que a vedação à contradição deixa de incidir aos órgãos judiciais, como veremos adiante.

\subsubsection{Base legal da preclusão para o juiz}

\footnotetext{
581 Parece ser esse o entedimento de HeITOR VITOR MENDONÇA SICA, ao afirmar que "essa figura [a preclusão consumativa] parece adequada justamente para designar a preclusão que recai sobre questões incidentais, já que o único meio de obstar o poder do juiz de decidir alguma questão se baseia exclusivamente no fato de já tê-lo feito antes" (Preclusão processual civil, p. 267). No mesmo sentido afirma ANTONIO DO PASSO CABRAL, Nulidades no processo moderno, pp. 264-265.
} 
A existência de embasamento legal para o fenômeno das preclusões para o juiz é controvertida, havendo quem afirme inexistir norma expressa, ou aqueles que defendem a base do instituto no art. 471, no art. 473 ou no art. 463 do Código de Processo Civil.

$\mathrm{O}$ art. 471 é o mais bem aceito pela doutrina como forma de conferir embasamento legal às preclusões para o juiz. Ao enunciar que "nenhum juiz decidirá novamente as questões já decididas, relativas à mesma lide", entendem alguns que ele esteja fazendo menção tanto à coisa julgada quanto à preclusão para o juiz ${ }^{582}$.

Segundo MonIZ DE ARAGÃO, a primeira parte do artigo ("nenhum juiz decidirá novamente as questões já decididas") se refere à coisa julgada material, o que é corroborado pelos seus dois incisos, vez que tais previsões se referem aos efeitos de determinada decisão em outros processos ${ }^{583}$. Todavia, ao utilizar a expressão "nenhum juiz", bem como a palavra "decidir", o artigo em destaque, em verdade, estaria fazendo menção também ao juiz da mesma causa, e que estaria vinculado não só ao que proferido em sentenças, mas também àquelas matérias decididas incidentalmente no curso do processo $^{584}$.

Entretanto, conforme expõe HeITOR Vitor Mendonça SiCA, o artigo é visto por outros doutrinadores como apenas atinente à coisa julgada. Por isso, concluiu o autor que "em face dessas tormentosas dúvidas interpretativas, achamos por bem deixar a norma de lado e perquirir que outros elementos do Código indicaram se a preclusão sobre questões é típica ou atípica" ${ }^{\text {"585. }}$.

O artigo 473 é ainda mais problemático. Uma grande parte da doutrina o entende como reforço ao artigo 471 do Código de Processo Civil, permitindo-se, a partir dele, identificar a base legal para a aplicação das preclusões para o juiz no processo ${ }^{586}$. Todavia, ao determinar que "é defeso à parte discutir, no curso do processo, as questões já decididas, a cujo respeito se operou a preclusão", é manifesta a destinação do artigo 473 do CPC às partes, e não ao juiz. Assim, quem entende possível ser essa a base legal para a

\footnotetext{
${ }^{582}$ FERNANDO CAIS, Preclusão e a instrumentalidade do processo, p. 64 e nota 180; MAURícIO GIANNICO, $A$ preclusão no direito processual civil brasileiro, p. 141; HUMBERTO THEODORO JÚNIOR, A preclusão no processo civil, p. 14; EgAS DiRCEU Moniz de ARAGÃo, Preclusão, p. 166; AlCides MunHOZ DA CUNHA, Correlação lógica entre cognição, preclusão e coisa julgada, p. 372 ANTONIO DO PASSO CABRAL, Nulidades no processo civil moderno, p. 264.

583 Preclusão, p. 169.

${ }^{584}$ Preclusão, p. 169.

${ }^{585}$ HeITOR Vitor MENDONÇA SiCA, Preclusão processual civil, p. 227.

${ }^{586}$ MAURÍCIO GIANNICO, A preclusão no direito processual civil brasileiro, p. 142.
} 
preclusão para o juiz acaba por confundir esse instituto com a preclusão dirigida à atividade das partes.

E essa confusão não deve ser feita. Como já destacado, trata-se de fenômenos dinstintos, que incidem em objetos também diversos: a preclusão destinada às partes incide sobre os ônus processuais a elas concernentes, ao passo que a preclusão para o juiz incide sobre o poder de reapreciar questões já decididas. E o fato de a parte não mais poder exercer um determinado ônus processual, seja porque passado o momento julgado pela lei como apropriado para tanto, seja pela prática de ato anterior contraditório, não significa dizer que o juiz está impedido de reapreciar determinada questão. Basta pensar, mais uma vez, nas questões cognocíveis de ofício pelo magistrado: independentemente de as partes poderem realegá-las, sem a figura da preclusão para o juiz, seria possível que o magistrado revisitasse sua própria decisão ${ }^{587}$.

Isso basta para identificarmos também a falha no apontamento do artigo 473 do Código de Processo Civil como apto a conferir o embasamento legal às preclusões para o juiz.

Com relação ao artigo 463 do CPC, trata-se de caso peculiar de preclusão, aplicável somente às questões resolvidas na sentença e que gera uma imutabilidade ainda mais forte do que a preclusão em geral, pois sequer as questões cognocíveis de ofício podem ser alteradas ${ }^{588}$. Assim, apesar de se tratar de uma hipótese de preclusão, é um caso específico, cujo fundamento legal não se estende às demais possibilidades de preclusão.

Por esses motivos, entendemos ser mais acertada a conclusão de HEITOR VITOR MENDONÇA SICA, segundo a qual as preclusões para o juiz têm natureza atípica, ou seja, decorrem da interpretação do sistema processual de uma maneira genérica. E tal constatação se comprova pelo fato de que o sistema impõe ônus às partes para evitarem a preclusão de questões, assim como determina ao juiz hipóteses específicas de alteração de suas decisões, admitindo-se, a contrario sensu, a impossibilidade de alteração nos demais casos. É o que se depreende, no primeiro caso, v.g., pelo ônus de interpor agravo retido a

\footnotetext{
587 A diferenciação entre preclusão das partes, preclusão do juiz e o art. 473 é feita por HEITOR VITOR MENDONÇA SICA, Preclusão processual civil, pp.227-228.

588 “Trata-se de preclusão muito mais forte e profunda do que aquela incidente sobre as questões enfrentadas por mera decisão interlocutória, pois as exceções à sua aplicação vem taxativamente enunciadas pelos incisos do artigo, ou seja, a correção dos erros materiais e para as alterações decorrentes do acolhimento de embargos declaratórios. (...). Em suma, estamos diante de uma preclusão típica (e mais forte), a qual impede o juiz de primeiro grau de redecidir o que foi resolvido na sentença. Os dois demais níveis de estabilização das sentenças são justamente a coisa julgada formal e material, do qual discorreremos, suscintamente, no item seguinte” (HEITOR VITOR MENDONÇA SICA, Preclusão processual civil, p. 215).
} 
fim de se evitar a preclusão de questões e, no segundo, pela existência de hipóteses taxativas de retratação ${ }^{589}$.

\subsubsection{Exceções à preclusão para o juiz}

De fundamental importância analisarmos hipóteses de exceção à preclusão para o juiz.

Segundo HEITOR VITOR MENDONÇA SICA ${ }^{590}$, as decisões que não estão sujeitas à preclusão para o juiz, ou seja, que podem ser reapreciadas, dividem-se em duas espécies: (i) casos em que a lei assim permite mediante a provocação da parte, independentemente do conteúdo da decisão e (ii) por causa da peculiaridade do conteúdo da decisão, independentemente da provocação das partes.

No primeiro grupo encontram-se as hipóteses legais de retratação. Estão atreladas à interposição de recurso das partes contra a decisão, permitindo-se, assim, que o juiz reconsidere a questão antes mesmo de o recurso ser julgado pelo Tribunal. Assim é o que dispõem, todos do Código de Processo Civil: a) o artigo 529, com relação ao Agravo de Instrumento; b) o artigo 518, $\S 2^{\circ}$, uma vez apresentada a resposta do recurso de Apelação, quanto ao reexame da admissibilidade; c) o artigo 296, quando interposto recurso contra o indeferimento da inicial; d) e o artigo 285-A, $\S 1^{\circ}$, quanto interposta Apelação em face da sentença que rejeita liminarmente o mérito.

Trata-se das hipóteses taxativas a que se fez referência, por meio das quais o legislador excepcionou a preclusão para o juiz em um espaço determinado de tempo (até logo após a primeira oportunidade de retratação uma vez interposto o recurso) ou condicionada a um evento certo (como a apresentação de contrarrazões ao recurso de apelação), permitindo-se a reapreciação de questão já decidida, considerando a possibilidade de reforma da decisão diante da notícia de interposição do recurso. Em todos os casos, a finalidade dessa reapreciação é a economia processual, evitando-se a demora do julgamento pela instância superior.

\footnotetext{
${ }^{589}$ HeITOR VITOR MENDONÇA SICA, Preclusão processual civil, pp. 228-230.

${ }^{590}$ Preclusão processual civil, p. 202.
} 
O segundo grupo envolve todas aquelas decisões que, pelo seu teor, estariam livres da preclusão para o juiz. É o que a maioria da doutrina chama de questões de ordem pública, passíveis de serem conhecidas de ofício ${ }^{591}$, pela presença do interesse público de que sejam resolvidas de modo a garantir a efetividade do processo. Daí a afirmação de que podem ser conhecidas a qualquer tempo e em qualquer grau de jurisdição, bem como de que estariam imunes à preclusão para o juiz ${ }^{592}$.

Ainda segundo a classificação de HeITOR VitOR MENDONÇA SiCA ${ }^{593}$, pode-se destacar cinco subgrupos dessas decisões que, pelo seu conteúdo, não se sujeitam à preclusão, quais sejam, aquelas referentes (i) às condições da ação e aos pressupostos processuais; (ii) ao controle de regularidade formal do processo; (iii) aos poderes instrutórios do juiz; (iv) aos poderes do juiz na utilização de meios de apoio à execução e à efetivação da tutela antecipada e (v) aos poderes administrativos do juiz.

Inicia-se pelo último dos subgrupos, pela menor controvérsia sobre o tema. Ao determinar que a parte recolha o complemento das guias, por exemplo, o juiz atua no interesse arrecatório do Estado, ou seja, há um interesse público manifesto e exclusivo. Nesse caso, não se justifica a aplicação da preclusão porque prepondera o interesse na arrecadação do preço público, o que não pode ser impedido pela preclusão para o juiz ${ }^{594}$.

Seguindo a ordem invertida da análise dos subgrupos, os chamados "meio de apoio" são aquelas ferramentas coercitivas à disposição do magistrado para garantir a efetividade de suas decisões no que se refere à execução de obrigação de fazer e não fazer e à antecipação de efeitos da tutela (artigos 461, 461-A e 287 do CPC). São medidas a serem adotadas também no interesse público de conferir efetividade às decisões judiciais, 0 que é corroborado por prescindirem da provocação da parte para serem determinadas.

\footnotetext{
${ }^{591}$ Para EDSON RIBAS MALACHINI, a exceção à preclusão se dá nos casos em que a lei permite cognição de ofício da matéria, conforme afirma em Alegações imprecluíveis e dever judicial de cognição ex officio, p. 68. O problema é que, nas lições de RICARDO DE CARVALHO APRIGLIANO, "Não há necessária coincidência entre matérias de ordem pública e os poderes de atuação ex officio do magistrado" (Ordem pública e processo, p. 108), como bem demonstra nas páginas seguintes de sua obra. Inclusive, para o autor, questões de ordem pública, em âmbito processual, são "hipóteses taxativas, que são as condições da ação, os pressupostos processuais e as nulidades absolutas" (Ordem pública e processo, p. 105), ou seja, somente seriam ordem pública os grupos (i) e (ii) da classificação de HEITOR VITOR MENDONÇA SICA infra destacada.

592 "Há, porém, casos em que, mesmo tendo ocorrido decisão sobre questão processual, continuará franqueado o juízo de reexame pelo Magistrado. As questões ligadas aos pressupostos processuais e às condições da ação, bem como todas as demais que, sendo de ordem pública, devem ser conhecidas de ofício pelo Juiz, não podem sofrer os efeitos da preclusão temporal" (HUMBERTO THEODORO JÚNIOR, A preclusão no processo civil, p. 22). No mesmo sentido, destaca-se: ALEXANDRE BARROSO, Acesso à justiça e preclusão civil, pp. 148-149; GALENO LACERDA, Despacho saneador, p. 161.

${ }^{593}$ Preclusão processual civil, pp. 230-249.

594 Preclusão processual civil, p. 246. No mesmo sentido afirma EGAS Moniz DIRCEU DE ARAGÃO, Preclusão, p. 171 e MANOEL CAETANO FERREIRA FILHO, A preclusão no direito processual civil, p. 26.
} 
Temos dúvida quanto à inexistência de preclusões para o juiz nesse caso. Os poderes coercitivos à disposição do juiz podem ser exercidos de ofício a fim de se atingir a efetividade. Mas será que o magistrado poderia simplesmente rever a decisão, sem qualquer alteração fática do caso? Parece-nos que o grande motivo de se defender essa hipótese como exceção à preclusão para o juiz está na preocupação em se garantir que, mostrando-se ineficaz uma medida, o juiz poderia adotar outras a fim de continuar a busca pela efetividade.

Todavia, uma vez demonstrada a ineficácia de um meio coercitivo utilizado, cria-se uma alteração de um dado da realidade que não pode ser desconsiderado. Altera-se, em verdade, o suporte fático da questão, no qual passa a ser acrescido um novo dado, qual seja, além na inadimplência, utilizou-se o incentivo $x$ para o cumprimento da obrigação e ainda assim ele foi ineficaz, houve um descumprimento a uma ordem estatal. Isso permite que haja nova decisão, pois fundada em nova questão, dada a alteração de um de seus elementos identificadores.

Quanto aos poderes instrutórios, a primeira ressalva a ser feita é a de que eles podem ser exercidos a qualquer tempo, vez que o juiz não está submetido à preclusão temporal $^{595}$. O que se indaga, portanto, é se ele pode rever uma decisão quanto à produção de determinada prova que já fora resolvida em momento anterior ${ }^{596}$.

E nesse ponto, a doutrina diverge. Baseando-se na possibilidade conferida por lei de o juiz atuar de ofício na instrução do processo, entendem alguns que ele poderia rever suas decisões de maneira ampla, ou seja, indeferir o já deferido anteriormente, e viceversa $^{597}$. Outros, por sua vez, entendem que somente nos casos em que indeferida a prova, ela poderia ser posteriormente deferida, mas, uma vez deferida a produção, surgiria para a parte o direito a ela, sendo vedada a mudança de entendimento do juiz nesse ponto ${ }^{598}$.

\footnotetext{
595 DANIEL NeVes, Preclusões para o juiz, p. 266; SIDNEY PereIRA DE SOUZA JUNIOR, Preclusão pro judicato na determinação das provas e a "limitação" do poder instrutório do juiz, p. 267.

${ }^{596}$ DANIEL NEVES bem define os conflitos que envolvem o tema: "pode o juiz, tendo determinado uma prova ex officio, voltar atrás e indeferi-la sem a devida interposição de recurso pela parte pretensamente interessada na revogação da medida? Pode o juiz deferir uma prova requerida por um dos litigantes para mais tarde tê-la por inadmissível ou desnecessária e indefiri-la? O juiz pode indeferir uma prova e, sem que haja interposição de recurso, em provimento posterior, determinar sua produção?” (Preclusões para o juiz, p. 266).

597 MAURícIO GIANNICO, A preclusão no direito processual civil brasileiro, pp. 181-191; HUMBERTO THEODORO JÚNIOR, A preclusão no processo civil, p. 23; JOÃO BATISTA LOPES, Breves considerações sobre o instituto da preclusão, p. 17; HeITOR VITOR MENDONÇA SICA, Preclusão processual civil, p. 242. FREDIE DIDIER JR., Curso de direito processual civil, p. 566.

${ }^{598}$ DANIEl Neves, Preclusões para o juiz, p. 266-272; SIDNEY PereIRA DE SoUZA JUNIOR, Preclusão pro judicato na determinação das provas e a "limitação" do poder instrutório do juiz, p. 270.
} 
Filiamo-nos à segunda interpretação pelo seguinte motivo: diferentemente das duas hipóteses anteriores, apesar de o poder instrutório do juiz certamente existir em favor do interesse público, é certo que o direito à produção da prova é autônomo e visa também a atender interesse das partes $^{599}$. Não obstante competir ao magistrado a análise da pertinência de produção de determinada prova no curso do processo (art. 130 do CPC), uma vez se concluindo pela necessária realização, surge para parte o direito de vê-la produzida. Disso decorre que o juiz não poderá simplesmente mudar de ideia e deixar de produzir prova já deferida.

Situação diversa, porém, será aquela em que justificadamente o juiz "mudar de ideia", e optar pela não produção da prova anteriormente deferida de maneira fundamentada. Em outras palavras, o juiz não pode simplesmente indeferir o já deferido, porque consolidado está o direito da parte de ver a prova produzida. Todavia, as circunstâncias fático-probatórias do processo podem se alterar de modo a configurar nova questão o tema da produção daquela prova e, assim, nada impediria que o juiz revisitasse sua decisão. Aplicar-se-ia, aqui, o que dispusemos sobre a identificação de questões ${ }^{600}$.

No que se refere à decisão de indeferimento, por sua vez, há de se considerar a existência de exceção à preclusão para o juiz. Uma vez indeferida a produção de uma prova pelo magistrado, se, em momento posterior, ele quiser rever sua decisão e determinar a produção, porque ainda não formada sua convicção, não há óbices para que assim proceda. Afinal, vale a pena lembrar que os institutos processuais devem ser sempre interpretados segundo a sua finalidade ${ }^{601}$, e de nada adiantaria considerar tal decisão preclusa a fim de evitar contramarchas no processo e, de outro lado, julgar o feito sem a produção da prova, que poderia ser suprida em grau recursal pela realização de diligência acarretando ainda mais demora - ou, pior, manter a decisão proferida sem todas as provas

\footnotetext{
${ }^{599}$ Sobre o tema, $c f$., por todos, FLÁVIO LUIZ YARSHELL, Antecipação da prova sem o requisito da urgência e direito autônomo à prova.

${ }^{600}$ Por ora, estamos analisando apenas a questão dos poderes instrutórios e a preclusão. Mas, se já pudemos adiantar, não se configuraria venire caso o juiz indefira prova já deferida, mas para julgar a demanda procedente em favor daquele que pleiteara a prova: além de aqui não haver qualquer nulidade pela ausência de prejuízo, essa contradição não seria afrontadora de boa-fé - nem da parte vencedora, por óbvio, mas também nem da parte vencida, a qual não tinha confiança de que a prova pedida pela parte adversa a beneficiaria.

${ }^{601}$ Sobre o tema, $c f$. José RoBERTO dos SANTOS BEDAQUE, Efetividade do processo e técnica processual. O seguinte trecho é ilustrativo das ideias do autor: "É preciso, portanto, eliminar do processo os formalismos inúteis, desconsidendo-se-os sempre que os objetivos almejados possam ser conseguidos independentemente deles. Na mesma medida em que o processo é instrumento de realização do direito material, a forma constitui instrumento destinado a que o processo alcance objetivos dele esperados e que constituem sua razão de ser. A forma não é fim, é meio. E como tal deve ser tratada. Esta visão teleológica, finalista, é essencial à compreesão e correta aplicação da técnica processual" (Efetividade do processo e técnica processual, p. 92).
} 
passíveis de serem realizadas e que, pela alteração da avaliação do caso concreto pelo juiz, pareceram essenciais.

Assim, quanto aos poderes instrutórios do juiz, conclui-se que representam exceção à preclusão ora tratada na hipótese de indeferimento da produção de determinada prova e posterior alteração desse posicionamento.

Os dois últimos subgrupos podem ser analisados conjuntamente, porque o mesmo raciocínio é a eles aplicado ${ }^{602}$. Tanto o controle da regularidade formal do processo quanto os casos de análise do preenchimento das condições da ação e dos pressupostos processuais, segundo a lei processual, podem ser apreciados de ofício (artigos 207, §3; $301, \S 4^{\circ}, 113 ; 303$, inc. II, todos do CPC) de modo a evitar que o procedimento siga seu curso sem reunir as condições necessárias para tanto, em nítida desatenção ao interesse público. A partir disso, entende a doutrina majoritária que esses temas poderiam ser revisitados indefinidamente, sem se sujeitarem à preclusão ${ }^{603}$.

Uma corrente minoritária defende a existência de preclusão para o juiz também para os casos de juízo de admissibilidade do processo ${ }^{604}$, ou seja, nas hipóteses em que houve o juízo positivo de admissibilidade - já que, como veremos, não existe decisão implícita e, com relação ao juízo negativo, este seria seguido de decisão que determinasse a regularização ou que extinguisse o processo sem julgamento do mérito.

Em outras palavras, havendo decisão que expressamente admita o preenchimento dos pressupostos processuais e das condições da ação, o juízo estaria a ela

602 "O fundamento para se excluir a preclusividade do reconhecimento das nulidades absolutas é o mesmo que está em torno do controle das condições da ação e dos pressupostos processuais, isto é, o respeito a normas em que prepondera o interesse público" (HEITOR VITOR MENDONÇA SICA, Preclusão processual civil, p. 236).

603 HeItor Vitor Mendonça SiCA, Preclusão processual civil, pp. 230-239; Egas DirceU MonIZ DE ARAGÃo, Preclusão, p. 173.

${ }^{604}$ Fredie DIDIER JR., Curso de direito processual civil, v. 1, pp. 561-567. JoÃo BATISTA LOPES, apesar de defender a inexistência de preclusão para reapreciação das condições da ação e dos pressupostos processuais, apresenta uma visão mais restritiva das exceções, pois nem todas as questões de ordem pública estariam imunes: "Em princípio, poderíamos ser levados à conclusão de que a preclusão não pudesse prevalecer quando se tratasse das decisões interlocutórias em matéria de ordem pública, porque um interesse mais alto e relevante se colocaria diante do princípio do impulso oficial e da celeridade processual. Entretanto, em nome da segurança jurídica e da estabilidade das decisões, não é esse o entendimento melhor. Como adverte ARRUDA ALVIM, se a lei previu recurso, nesses casos, ao intérprete não cabe fazer distinções não previstas em lei. Também interessa à ordem pública a celeridade processual e as estabilidades das decisões judiciais, razão pela qual deve ser respeitado o princípio da preclusão." (Breves considerações sobre o instituto da preclusão, p. 24). Da mesma maneira, afirma MANOEL CAETANO FERREIRA FILHO que "no contexto do código, o $\$ 3^{\circ}$ do art. 267 apenas libera o juiz para apreciação de ofício da existência das condições da ação e dos pressupostos processuais. Todavia, uma vez proferida a decisão, nao mais poderá o juiz decidir novamente a questão" (A preclusão no direito processual civil, p. 106 - o autor relativiza essa preclusão para o Tribunal, que pode apreciar posteriormente a questão mesmo que já resolvida em primeiro grau e contra ela não tenha sido interposto o recurso cabível tempestivamente). 
vinculado, sem possibilidade de reapreciação caso mantida a identidade dos elementos da questão $^{605}$.

E isso porque, em primeiro lugar, nas hipóteses em que se permite a apreciação de determinadas questões a qualquer momento do processo (tal como estabelece o art. 267, $\S 3^{\circ}$, do CPC), é preciso diferenciar a possibilidade de enfrentamento, pela primeira vez, de determinada questão, não importa em que fase o processo esteja ${ }^{606}$, da possibilidade de reapreciação, o que não foi expressamente autorizado em nenhum dispositivo legal ${ }^{607}$.

Admitir a possibilidade ilimitada de reapreciação dessas questões - ou melhor, limitada apenas pela coisa julgada formal, mas, até o trânsito em julgado, não haveria limites - significa aceitar uma demora irrazoável no processo, assumindo uma inversão de valores, ou seja, assume-se "haver uma intenção não-revelada de permitir sempre a possibilidade do não-enfrentamento do mérito, como se isso fosse o desejável, como se isso fosse o mais importante" 608 .

E apesar dessa ser uma corrente bastante minoritária, compartilhamos de suas ideias. A possibilidade de reapreciação quase indefinida das questões referentes ao juízo de admissibilidade fere a segurança jurídica e eleva de maneira desproporcional o grau de importância dado a essas barreiras processuais.

${ }^{605}$ FREDIE DIDIER JR. faz a ressalva de que, ocorrido fato superveniente, daí então não ocorreria a preclusão (Curso de direito processual civil, p. 564). Pelo que exposto até aqui, porém, parece-nos desnecessário fazer a mesma ressalva já que, evidentemente, o fato superveniente representa alteração do suporte fático e, portanto, alteração da própria questão.

${ }^{606}$ Mesmo esse pressuposto já é posto em xeque pela doutrina. RICARDO DE CARVALHO APRIGLIANO, por exemplo, entende que o último momento em que deve ocorrer tal apreciação deve ser o saneamento, para que os pressupostos processuais e as condições da ação cumpram sua função de impedir o prosseguimento de um processo que não reúne as condições necessárias para tanto, em prol da economia processual. A partir desse momento, porém, seria descabido extinguir um processo por ausência de condição da ação ou pressuposto processual, sob pena de se "reforçar o instituto [da ordem pública] como mera ferramenta para extinção de processos fora de época e sem motivo justo." (Ordem pública e processo: o tratamento das questões de ordem pública no direito processual civil, p. 169).

607 "Não há qualquer referência no texto legal, porém, à inexistência de preclusão em torno das questões já decididas. A qualquer tempo é possível conhecer tais questões, controlar a regularidade do processo, desde que o processo ainda esteja pendente e que não tenha havido preclusão a respeito. (...) Parece haver uma confusão entre a possibilidade de conhecimento ex officio de tais questões, fato indiscutível, com a possibilidade de decidir de novo questões já decididas, mesmo as que poderia ter sido conhecidas de-ofício. São coisas diversas: a cognoscibilidade ex officio de tais questões significa, tão somente, que elas podem ser examinadas pelo Judiciário sem a provocação das partes, o que torna irrelevante o momento em que são apreciadas. Não há preclusão para o exame das questões, enquanto pendente o processo, mas há preclusão para o reexame.” (FREDIE DIDIER JR., Curso de direito processual civil, v. 1, p. 563). As ideias de PAULO CERQueIRA CAMPOS são similares, ressaltando-se o fato de que, para o autor, uma vez o Juízo de Primeiro Grau decidindo sobre as condições e pressupostos, ele não poderia mais rever a matéria, mas poderia fazê-lo a Segunda Instância em qualquer oportunidade em que fosse devolvida a matéria, e não somente pela imediata interposição do recurso cabível quando apreciada a questão (A preclusividade de poderes de juiz. como uma das formas de se conferir efetividade ao atual processo civil brasileiro, pp. 34-36).

${ }^{608}$ FREDIE DIDIER JR., Curso de direito processual civil, p. 565. 
Uma vez já tendo sido proferida decisão no sentido de reconhecer preenchidos os requisitos de admissibilidade para o prosseguimento da ação, sem que tal decisão tenha sido alterada por qualquer meio de impugnação que o sistema coloca à disposição das partes, desnecessária a reapreciação sem que haja alteração de qualquer elemento da questão. Permitir o contrário significa viabilizar contramarchas desnecessárias ao processo, que ferem o princípio da economia processual e da segurança jurídica, além de desprestigiarem a apreciação do mérito.

Ocorre que, inadmitindo essas hipóteses como uma exceção, traçamos o seguinte panorama: há exceções à preclusão para o juiz em casos de admissibilidade expressa pelo sistema, a despeito do conteúdo das decisões e, quanto ao critério do conteúdo, somente as decisões que (i) digam respeito aos poderes administrativos do juiz; e (ii) indefiram a produção de determinada prova, estão imunes à preclusão para o juiz. Todas as demais, apesar de entendimento diverso majoritário na doutrina, defendemos que, uma vez decididas, não podem ser reapreciadas em um mesmo processo, de modo que refutamos a qualidade de "ordem pública" como um fato divisor de águas para a incidência ou não da preclusão ${ }^{609}$.

\subsubsection{Ausência de decisões implícitas e de preclusão sobre o não-decidido}

Por fim, como último tema a ser enfrentado antes de podermos comparar o instituto da preclusão com a hipótese de comportamentos processuais contraditórios, investiguemos a possibilidade de existirem decisões implícitas em nosso ordenamento, de modo que, uma vez se omitindo o juiz de se pronunciar em momento adequado sobre determinada questão, poder-se-ia considerá-la resolvida de modo a impedir a sua ("re")apreciação.

Poucas são, atualmente, as vozes que defendem a existência de decisões implícitas em nosso ordenamento. GALENO LACERDA chega a admitir a existência de

\footnotetext{
${ }^{609}$ RICARDO DE CARVALHO APRIGLIANO não chega a dissociar por completo a preclusividade e a ordem pública, mas admite que "com o devido acatamento à posição absolutamente majoritária que defende posição oposta, é lícito asseverar que o ordenamento processual brasileiro, tal qual hoje posto, fornece os elementos para afirmar a preclusão da questão de ordem pública, no mínimo para o mesmo juiz, que fica impedido de a ela voltar por ocasição da decisão de mérito" (Ordem pública e processo, p. 182). Ou seja, o autor limita o reexame a partir do momento em que o mérito é julgado. Vamos além e destacamos que mesmo as matérias de ordem pública, uma vez decididas, depois de utilizados os meios recursais cabíveis, precluem antes mesmo do julgamento do mérito.
} 
decisões implícitas quanto a questões que ele chama de anulabilidades, ou seja, que representam "infração de norma dispositiva em relação à parte"610. Nessas hipóteses, afirma o autor, "a inexistência de recurso, quando o juiz declarar genericamente saneado o processo, ou se limitar a designar audiência, implica renúncia tácida à reação contra a anulabilidade, e esta convalecerá pela omissão do prejudicado"611.

JosÉ Frederico MARQUeS, por sua vez, aduz que inexiste preclusão caso nenhuma das partes tenha alegado e também o juiz tenha deixado de se manifestar sobre qualquer matéria cognocível ex officio. Todavia, afirma que se algum dos sujeitos parciais arguir uma preliminar, a decisão que declara saneado o processo será atingida pela preclusão para o juiz. Dessa maneira, mesmo o juiz nada dizendo no saneamento sobre a preliminar, a questão não poderá ser analisada porque haveria preclusão sobre esse julgamento implícito ${ }^{612}$.

O autor parece confundir a preclusão para o juiz com a preclusão para as partes, pois faz com que aquela dependa da alegação desta, misturando os critérios aferidores da preclusão quanto a questões decididas e preclusão dos ônus das partes. Com base nessa crítica, e com os argumentos a seguir demonstrados, prevalece na doutrina o entendimento de que, de maneira incondicionada - ou seja, independentemente do teor da decisão ou do fato de a parte ter ou não suscitado a matéria -, inexistem decisões implícitas em nosso ordenamento ${ }^{613}$.

Isso porque uma decisão implícita seria desprovida de qualquer fundamentação, o que afronta o artigo 93, inciso IX, da Constituição Federal. O referido artigo constitucional determinou a motivação de todas as decisões, inclusive, portanto, as interlocutórias. Tal previsão legal, afirma-se, mais do que dever ser respeitada pelo simples fato de estar prevista em nossa Carta Magna, tem razões de ser imprescindíveis para um ordenamento que se pretenda democrático. Afinal, somente por meio da fundamentação é

\footnotetext{
${ }^{610}$ Despacho saneador, p. 160.

611 Despacho saneador, pp. 174-175. É importante ressaltar que o autor tem visão restrita quanto à possibilidade de decisões implícitas, pois todas as demais questões de nulidades absolutas ou relativas não poderiam ser consideradas decididas, a não ser expressamente. E isso porque se trata de decisões que devem ser fundamentadas, ou que dependem de instrução, de modo que "o silêncio do juiz a respeito dessas questões, embora levantadas na fase postulatória, deve ser interpretado como recusa a decidí-las antes da sentença final" (Ibidem, p. 172).

${ }^{612}$ José Frederico MARQues, Manual de Direito Processual Civil, p. 181.

${ }^{613}$ Nesse sentido: MAURÍCIO GIANNICO, A preclusão no direito processual civil brasileiro, pp. 158-161; JOÃO BATISTA LOPES, Breves considerações sobre o instituto da preclusão, p. 21; HEITOR VITOR MENDONÇA SICA, Preclusão processual civil, pp. 208-212; EgAS DIRCEU MonIZ DE ARAGÃo, Preclusão, p. 173; DANIEL AMORIM ASSUMPÇÃo NEVES, Preclusões para o juiz, pp. 235-238; AlEXANDRE BARROSO, Acesso à justiça e preclusão civil, pp. 144-146; FREDIE DIDIER JR., Curso de direito processual civil, p. 565.
} 
possível identificar o caminho lógico percorrido para se chegar a determinada decisão e, assim, permite-se o controle da qualidade da prestação jurisdicional ${ }^{614}$.

Ademais, a fundamentação é imprescindível garantia para viabilizar a própria recorribilidade da decisão. Ora, uma vez admitida a decisão implícita, contra quais argumentos as partes deverão se insurgir em sede de recurso? Daí então a prevalência das vozes que defendem ser essencial a fundamentação, adotando-se a vedação no nosso sistema processual de decisões implícitas. Disso decorre que, caso o juiz jamais tenha apreciado determinada questão, inexiste espaço para se falar em preclusão para o juiz.

O que pode haver, em alguns casos, é a impossibilidade de apreciação não porque houve decisão implícita, mas porque a lei processual determina que o juiz somente se pronuncie sobre determinadas questões se provocado a tanto. É o que se chamou de questões não suscitadas pela parte e por isso não decididas pelo juiz ${ }^{615}$.

Em outras palavras, existem matérias que não podem ser apreciadas pelo juiz sem que a parte não o provoque para tanto, nos termos do artigo 128 do Código de Processo Civil: "O juiz decidirá a lide nos limites em que foi proposta, sendo-lhe defeso conhecer de questões, não suscitadas, a cujo respeito a lei exige a iniciativa da parte.". Vêse, portanto, que nas hipóteses em que a lei condicione a apreciação de uma questão pelo juiz à provocação da parte, até que tal condição seja verificada, inexiste o poder do juiz de conhecer esse ponto. Tais situações, em geral, dizem respeito a questões cujo interesse é da parte $^{616}$.

Se, todavia, preclui o ônus da parte de alegar determinada matéria, seja porque transcorrido o prazo oportuno para tanto, seja pela prática de ato anterior contraditório a essa alegação, no curso dessa demanda o juiz não mais poderá ser provocado a apreciá-la e, assim, jamais surgirá para ele o poder para tanto. Essa hipótese nada mais é do que de preclusão da atividade das partes, que, por sua vez, gera efeitos para a apreciação de questões para o juiz. Mas esses efeitos não se equiparam ao da preclusão para o juiz, vez que ele não tinha o poder de apreciar a questão e o perdeu por já ter exercido esse poder:

\footnotetext{
${ }^{614}$ DANIEL AMORIM ASSUMPÇÃo NeVES, Preclusões para o juiz, p. 235.

${ }^{615}$ HeITOR VITOR MENDONÇA SiCA, Preclusão processual civil, pp. 184-187.

${ }^{616}$ FERnANDO CAIS, Preclusão e a instrumentalidade do processo, p. 63.
} 
aqui ele jamais possuiu o poder de apreciação, que era condicionado à atividade das $\operatorname{partes}^{617}$.

Conclui-se, portanto, que a maioria da doutrina afirma a inexistência de decisões implícitas em nosso ordenamento, o que inviabiliza a existência de preclusão para o juiz nesses casos.

Por fim, mister esclarecer que, fora dos casos em que permitida a reapreciação, uma vez o juiz reanalisando questão já decidida, essa segunda decisão é nula, porquanto vai de encontro à legalidade ${ }^{618}$.

\subsection{Diferenciações entre preclusão e venire}

Com base nesse panorama geral que buscamos traçar no que concerne ao instituto da preclusão, já é possível expor nossas ideias com relação às semelhanças e às diferenças que ela apresenta com relação ao comportamento processual contraditório, tema esse que é o foco de nossas preocupações.

\subsubsection{Preclusão lógica e venire}

No que se refere à comparação entre venire e preclusão aplicável às partes, é evidente que a justaposição entre preclusão consumativa e venire, bem como entre preclusão temporal e venire, é descabida: buscamos demonstrar a irrelevância daquela em nosso sistema e, no que diz respeito a esta, sequer a contrariedade é elemento relevante.

\footnotetext{
617 "Com efeito, se o juiz tem o poder-dever de definir determinada questão, não pode perdê-lo, independentemente do momento do processo. Se não o fez em determinado momento, pode fazê-lo depois. De outro lado, se o juiz não pode apreciar ponto sobre o que antes se omitiu é porque jamais poderia fazê-lo de ofício, e sem oportuna provocação da parte" (HEITOR VITOR MENDONÇA SICA, Preclusão processual civil, p 186). Temos que admitir que, nesse ponto, CHIOVENDA não diferenciou apropriadamente a preclusão da atividade das partes da preclusão destinada ao juiz, pois defendeu o autor italiano que "Dopo aver parlato della preclusione delle questioni decise, passiamo alla preclusione delle questioni non decise. Ogni questione, anche non proposta e quindi non decisa, rimane precusa dopo deciso definitivamente il punto a cui essa si referisce" (Cosa giudicata e preclusione, p. 271).

${ }^{618}$ HeITOR Vitor MendonÇA SicA, Preclusão processual civil, p. 183. O autor se baseia nas ideias mais profundamente desenvolvidas por ele mesmo no artigo já citado neste trabalho, Contribuição ao estudo da teoria das nulidades, pp. 192-193.
} 
Assim, compete-nos enfrentar se existentes ou não diferenciações entre preclusão lógica e venire.

Como alertamos desde o início deste Capítulo, a comparação deve ser feita com base em premissas bem fixadas, pois, a depender do que se entenda por preclusão, a coincidência com o venire pode ser estreita ou bastante distanciada. Com base nas premissas que fixamos acima, concluimos que apesar de similares, de fato, preclusão lógica e comportamento contraditório não podem ser tidos como figuras idênticas, e buscamos ressaltar essa diferença apenas para que o venire não se limite às barreiras comumente impostas ao fenômeno da preclusão, o que comprometeria a sua funcionalidade.

A semelhança está fundamentalmente no fato de que tanto preclusão lógica quanto nemo potest venire contra factum proprium se configuram a partir da comparação entre condutas incompatíveis entre si, fazendo surgir a possível consequência da ineficácia do comportamento incompatível.

Porém, das conclusões mais genéricas para mais específicas quanto a essa diferenciação, identificamos que o primeiro obstáculo para afirmar a coincidência total entre preclusão lógica e venire está na escassez do estudo doutrinário sobre a preclusão lógica propriamente dita.

Já tivemos oportunidade de ressaltar que são poucos os estudos doutrinários sobre o tema da preclusão, quando comparados com tantos outros objetos de estudo dos processualistas. E, dentre os estudiosos, são tantas as questões envolvendo o tema, que o enfrentamento de pontos específicos sobre a preclusão lógica é uma raridade: normalmente, os estudos limitam-se a apontar a existência da preclusão tendo por causa a incompatibilidade de condutas, e dá-se dois ou três exemplos práticos de situações em que ela se faz presente, apenas.

Já o estudo da vedação a comportamentos contraditórios tem sido feito com profundidade em âmbito civil, seara que bem definiu sua evolução histórica, pressupostos configuradores, finalidade essencial e efeitos. Dessa maneria, parece-nos arriscado comparar uma figura tão bem desenvolvida com outra que, per si, é carente de maiores estudos e compreensão, e que se revela bem conhecida somente quando inserida no contexto geral das preclusões, contexto que, quando expandido, distancia-se de qualquer semelhança com a vedação de comportamentos contraditórios. 
Em resumo, nossa primeira ressalva é a de que a aproximação entre preclusão lógica e venire demandaria uma compreensão maior daquela como figura autônoma. No estágio atual do entendimento do fenômeno, a preclusão lógica é mera modalidade de preclusão que, por sua vez, não é frequentemente relacionada ao venire. Esse é o primeiro fator que explica porque, com base em nossas premissas - que acabam sendo as mesmas premissas da doutrina majoritária e escassa sobre o tema ${ }^{619}-$, optamos por diferenciar ambos os institutos.

A segunda observação é feita com base em nossa opção metodológica sobre o estudo do comportamento processual contraditório. O escopo de nosso trabalho é estudar todas as possíveis consequências aplicáveis ao sujeito processual que age de forma contraditória no processo. Dentre as consequências identificadas, porém, não há somente a ineficácia do segundo comportamento, ou melhor, a perda da posição processual que se revelou contraditória - o que equivale à preclusão processual para as partes. Corforme será sistematizado no item 8.5 infra, é possível que outras consequências sejam aplicáveis, tais como aquelas concernentes à litigância de má-fé, bem como a valoração desse comportamento em contradição, e isso principalmente porque a contradição processual afeta o Estado-juiz, e não só os interesses privados das partes, gerando consequências peculiares.

Dessa maneira, preclusão lógica e comportamento processual contraditório diferenciam-se também pelas suas consequências. A preclusão é uma das possíveis consequências da adoção do comportamento processual contraditório, mas não a única $\operatorname{delas}^{620}$.

\footnotetext{
${ }^{619}$ Partimos das mesmas premissas do que venha a ser preclusão lógica, mas não chegamos às mesmas consequências, já que, para parte da doutrina, a preclusão lógica é a pura expressão do venire contra factum proprium aplicado ao processo. Nesse sentido, destaca-se, conforme já indicamos na Introdução deste trabalho: Fredie Didier JR. e Pedro NogueIRA, Teoria dos fatos jurídicos processuais, pp. 98-99. Da mesma maneira, destacam MARCELO MESA E CARLOS VIDE que "Este principio gravita fundamentalmente en nuestra legislación procesal. La doctrina de los actos propios se encuadraría así, cuando se ejercita en el proceso, en la segunda de las formas de preclusión [preclusão lógica]" ( La doctrina de los actos propios, p. 109). TALITA ROMEU afirma que "A preclusão também é um mecanismo que impede o exercício de comportamentos contraditórios no processo, ou seja, consiste em técnica que resguarda a confiança e a boa-fé dos atores processuais, proibindo o venire contra factum proprium no âmbito dessa relação jurídica" $(O$ princípio da boa-fé e o instituto da preclusão: a suppressio processual, p. 855). No mesmo sentido, cf. LORENA BARREIROS, Fundamentos constitucionais do princípio da cooperação processual, p. 293.

${ }^{620}$ Essa conclusão se coaduna com as ideias de GUSTAVO PRAZERES:"Enquanto a preclusão lógica é efeito jurídico que determina a ineficácia dos atos processuais que se demonstrem incompatíveis com outros anteriormente adotados, o princípio do venire contra factum proprium nulli conceditur é cláusula geral, sem efeitos pré-determinados, com ampla abrangência, que visa resguardar expectativas legítimas. Em diversas situações limítrofes, contudo, será bastante difícil, senão impossível, determinar se há incidência de um, de
} 
Uma terceira diferenciação entre as figuras está no escopo delas. É inequívoco que a vedação a comportamentos processuais contraditórios visa a proteger legítimas expectativas processuais, expectativas que decorrem da aplicação do princípio da boa-fé objetiva e da cooperação no processo.

A preclusão, por sua vez, tem por escopo fundamental garantir a marcha do processo, o "andar para frente", sendo que sua conexão com a boa-fé é feita de maneira pouco usual, não unânime e por vezes superficial. Para quem defende a intrínseca ligação entre preclusão e boa-fé, abre-se caminho para identificação de semelhanças entre aquela e o venire. Porém, como grande parte da doutrina não inclui dentre os escopos da preclusão o resguardo da boa-fé, (e, quando o faz, é quase de maneira acessória, sem conferir à boafé qualquer posição de destaque), ao aproximar o venire da preclusão lógica corre-se o risco de igualar figuras com escopos distintos.

Até aqui, para nós, só há uma escolha dentre duas possíveis opções: ou a preclusão lógica é mais bem destacada no estudo das preclusões, enaltecendo-se a ligação destas com a proteção da boa-fé, ou preclusão lógica e venire devem ser tratadas como figuras distintas, evitando-se o risco de desvirturar o escopo do venire e assemelhá-lo à função da preclusão, que é primordialmente diversa.

Porém, mesmo que superadas essas barreiras, há ainda uma diferença essencial, ligada também a esse último ponto referente ao escopo da preclusão: vimos que, como a finalidade primordial da preclusão é garantir a celeridade do processo e o seu desenvolvimento em direção ao resultado final, é coerente que seus efeitos sejam apenas endoprocessuais. Dessa forma, a preclusão para a parte corresponde à perda da possibilidade de exercitar um ônus processual dentro daquele mesmo processo, sem que isso implique vedações para o exercício do mesmo ônus em processos diversos.

A vedação de comportamentos processuais contraditórios, por sua vez, conforme será mais bem definido a seguir, não possui essa limitação. Pelo contrário, considerando a busca pela proteção da boa-fé, é possível que a vedação do exercício de uma conduta, por ser contraditória à conduta anterior de modo a afrontar expectativas decorrentes da boa-fé, estenda-se para além de uma única sede processual, porduzindo efeitos extraprocessuais.

outro, ou, quiçá, de ambos os institutos." (Venire contra factum proprium nulli conceditur $e$ direito processual, p. 159, nota 34 ). 
E ainda, não há notícias de que seja possível configurar a preclusão lógica a partir de uma omissão, de um não exercício de um ônus processual. A doutrina encontrada que se manifesta sobre o tema, pelo contrário, nega a possibilidade de a contradição de condutas se dar a partir de uma omissão ${ }^{621}$.

Essa limitação, porém, não se aplica à vedação de comportamentos contraditórios. Considerando mais uma vez o escopo de se proteger a boa-fé e a cooperação, é plenamente possível, apesar de mais raro do que as situações geradas pelas condutas comissivas, que as expectativas sejam emanadas a partir de prolongada omissão do exercício de uma posição jurídica processual. Nesse caso, será obstada a conduta contraditória posterior, sem que isso pudesse acontecer a partir da preclusão lógica.

Em verdade, não só a omissão é capaz de gerar expectativas a serem protegidas, mas qualquer situação jurídica processual exercida em liberdade - conforme veremos adiante. Por ora, o que buscamos fixar é que não só o exercício de ônus processuais implica possibilidade de configuração do venire, mas o exercício de outras situações jurídicas processuais também. Considerando que a preclusão para as partes incide sobre os ônus processuais, tem-se mais uma diferenciação.

Com essas considerações, pretendemos demonstrar que a preclusão lógica como hoje compreendida pela maioria da doutrina brasileira distancia-se da vedação de comportamentos contraditórios, uma vez que (i) não tem posição de destaque a ponto de enaltecer a proteção de expectativas fundadas na boa-fé e cooperação como deveria, já que essa é a finalidade do venire; (ii) tem efeitos limitados às barreiras endoprocessuais; (iii) não se configura a partir de um comportamento omissivo ou outras situações jurídico processuais que não o ônus e (iv) em verdade, revela-se apenas uma das possíveis consequências da adoção do comportamento processual contraditório.

\footnotetext{
${ }^{621}$ Ressalva seja feita à posição de TALITA ROMEU, que considera a suppressio como forma de preclusão lógica por omissão: "A perda dos poderes processuais, correspondente ao conceito de preclusão lógica, está embasada na boa-fé, porquanto busca impedir a atuação contraditória e surpreendente dos sujeitos da relação jurídica processual. Assim, a prática de um ato incompatível com a inatividade anterior do exercente, ensejando a quebra da confiança e da lealdade, também pode ser fulminada pela incidência da preclusão, com amparo na cláusula da boa-fé objetiva. Trata-se da aplicação da suppressio ao processo civil, extinguindo uma situação jurídica processual ativa devido à ausência de exercício por lapso temporal apto a gerar expectativas legítimas de que não mais seria praticada. Destarte, a suppressio processual consiste numa preclusão lógica fundada no princípio da boa-fé, pois o poder que se quer exercer é incompatível com a inação anterior do seu titular, restando impedido por contrariar a confiança suscitada nos demais sujeitos do processo" (O princípio da boa-fé e o instituto da preclusão: a suppressio processual, p. 857).
} 
Para, nós, portanto, as semelhanças entre preclusão lógica e venire devem ser compreendidas da seguinte maneira: imaginemos, em analogia à representação formulada em momento anterior, dois círculos secantes, um referente às preclusões destinadas às partes de maneria geral, e outro referente ao venire processual. Na parte do círculo das preclusões que não se comunica com o outro círculo, encontram-se as preclusões temporais - já que, frise-se, adotamos o posicionamento de que as preclusões consumativas destinadas às partes são dispensáveis em nosso sistema.

Na parte do círculo do venire que não se comunica com o das preclusões, encontram-se as situações de comportamentos processuais que afrontam à boa-fé objetiva processual (pois condutas contraditórias e quebra da boa-fé são pressupostos de qualquer venire, como será ressaltado no Capítulo seguinte), e que geram consequências outras para além da perda da posição jurídica processual, ou ainda, casos em que tal consequência se estende a outros processos ou que se verifica a partir de uma omissão ou outra situação processual que não o ônus.

$\mathrm{Na}$ parte compartilhada desses círculos, portanto, situam-se as preclusões lógicas: são as hipóteses em que há incompatibilidade de comportamentos de modo a se afrontar a boa-fé, e cujos efeitos resumem-se na perda da posição jurídica processual naquele processo específico. Dessa forma, a preclusão lógica estaria inserida no venire com possível consequência dele, do que decorre a conclusão de que preclusão lógica e venire não são figuras totalmente coincidentes, mas sim o venire é mais abrangente, absorvendo a preclusão lógica:

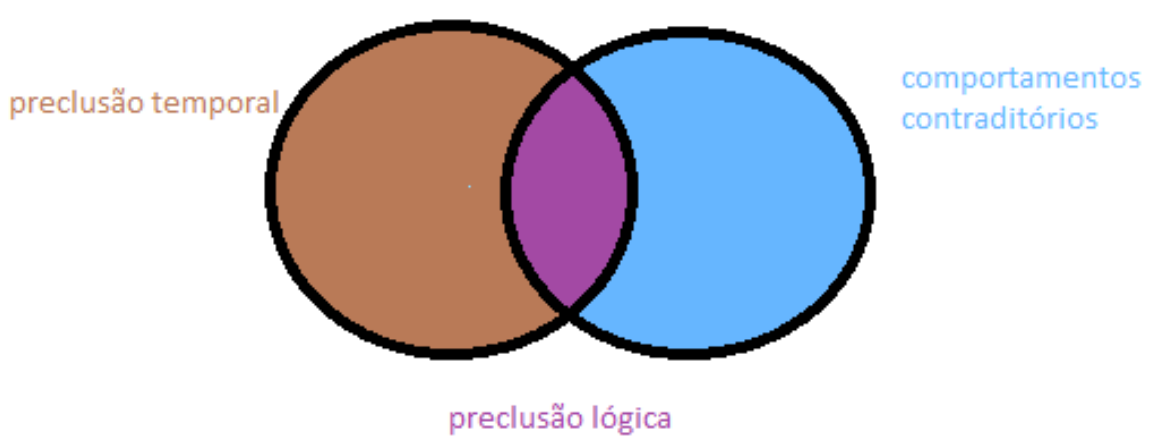

Nesse espaço de intersecção entre os círculos estão os casos em que identificadas as hipóteses de preclusão lógica, inclusive aqueles previstas na lei processual, motivo pelo qual concordamos com os autores que afirmam que a inspiração última do 
legislador ao expressar a vedação de algumas contradições processuais foi, ainda que intuitivamente, prestigiar o brocardo nemo potest venire contra factum proprium ${ }^{622}$.

Conclui-se, portanto, que, no que concerne à relação entre preclusão lógica e venire, trata-se de relação de abrangência, porém não de identidade. Tais conclusões importam ao sistema processual na medida em que permitem ampliar o controle de contradições processuais das partes e que sejam afrontadoras de expectativas, bem como viabilizam a melhor compreensão da preclusão lógica, sua funcionalidade e limitações. $O$ escopo é auxiliar o julgador frente a uma contradição, para que compreenda quais as possíveis medidas a serem tomadas, bem como esclarecer as possíveis consequências de tais comportamentos às partes e a seus procuradores.

\subsubsection{Preclusão para o juiz e venire}

Como vimos, preclusão para as partes e preclusão para o juiz são institutos, em verdade, distintos. Assim, não podemos deixar de comparar cada um deles com o venire de maneira igualmente separada.

A nossa premissa é a de que o fato gerador da preclusão para juiz é a consumação, ou seja, a impossibilidade de rever a decisão anterior se dá pelo simples fato de o tema já ter sido enfrentado, de modo que revisitações comprometeriam a celeridade e a segurança do processo, valores que justamente são protegidos pela preclusão.

Segundo nosso entendimento, ainda, uma mesma questão é assim identificada se coincidentes os pontos fáticos ou de direito, o suporte fático-jurídico que a embase e o acervo probatório que a alimenta. Havendo divergência de uma dessas características, duas questões não podem ser vistas como idênticas.

E, ainda retomando nossas premissas, não existe preclusão para o juiz com base na não-decisão, porque inexistem decisões implícitas em nosso ordenamento. E,

\footnotetext{
${ }^{622}$ Segundo ANTONIO DO PASSO CABRAL, "essa vedação de condutas incoerentes é a ratio essendi do art. 243 do CPC, art. 565 do CPP, art. 796, $b$, da CLT, e art. 501 do CPPM, ao atribuírem a legitimidade para arguir a nulidade apenas à 'parte que não lhe deu causa'. Vê-se agora que a questão deve ser tratada menos no campo de um 'princípio do interesse', mas sim na esfera da preclusão lógica ou do nemo potest venire contra factum proprium, que gera ilegitimidade ad actum, ou seja, uma incompatibilidade subjetiva para a impugnação" (Nulidades no processo moderno, pp. 315-316). No mesmo sentido quanto à relação entre o art. 243 do CPC e sua ratio essendi como sendo o venire, cf. CAMILA GonÇAlves, Princípio da boa-fé, p. 49 e TALITA ROMEU, O princípio da boa-fé e o instituto da preclusão: a suppressio processual, p. 858.
} 
dentre as decisões explicitamente tomadas, não se submetem à preclusão aquelas que digam respeito aos poderes administrativos do juiz, bem como as que indefiram a produção de determinada prova, ressaltando-se que esse entendimento é minoritário, comumente incluindo-se nas exceções à preclusão para o juiz as decisões sobre o controle da regularidade do processo (nulidades), bem como sobre condições da ação e pressupostos processuais.

Com base nisso, indaga-se se as preclusões para o juiz apresentam semelhanças ou diferenças com o venire aplicado ao órgão jurisdicional.

Considerando que a preclusão para o juiz, por ter como causa a consumação de decisão anterior (ou seja, a causa está no simples fato de a decisão já ter sido tomada anteriormente), já impede que o tema seja reenfrentado a despeito de haver risco de decisão contraditória ou não, em um primeiro momento sequer se faria necessária a incidência do venire para o órgão judicial, sendo a preclusão para o juiz um mecanismo bastante eficaz para obstar contradições entre decisões.

Todavia, há quatro grupos de situações em que há espaço para se falar em vedação de condutas contraditórias do órgão jurisdicional, hipóteses em que a preclusão não consegue, per si, vedar todas as possíveis contradições, quais sejam: (i) no campo das exceções à preclusão para o juiz; (ii) quando, pelo enfrentamento de questão não idêntica, o órgão jurisdicional acaba por contradizer decisão anterior; (iii) para proteger legítimas expectativas extraídas da não-decisão, ou seja, da omissão e (iv) em casos de confiança rompida pelo Judiciário perante partes coincidentes em processos distintos, porém conexos.

Esses quatro grupos evidenciam hipóteses em que possível o venire para o juiz porquanto a preclusão não foi capaz de afastar a contradição do órgão julgador. Mas, desde logo é fundamental ressaltar, para tanto é preciso que haja efetiva afronta de expectativas, ideia que ficará bastante clara no Capítulo seguinte.

7.4.2.1. Vedação de comportamentos contraditórios e exceções à preclusão para o juiz

No primeiro grupo situam-se os casos de exercício de poderes administrativos do juiz, de decisão que indefere a produção de determinada prova e, para a maioria, do 
controle da regularidade do processo, das condições da ação e dos pressupostos processuais. Nesses casos, ainda que admitida a possibilidade de rever decisão sobre esses temas porquanto inexista a preclusão para o juiz, é possível que eles tenham sido tão intensamente debatidos, que tenham apresentado expectativas de definitividade que não podem ser simplesmente quebradas por decisão posterior.

É claro que os casos de venire serão raros nas hipóteses em que permitida a preclusão para o juiz. Mas não podemos deixar de ressaltar esse espaço de possível incidência do venire (principalmente para aqueles que ampliam esse rol de exceções), deixando em aberto o preenchimento desse espaço para a jurisprudência, conforme as peculiaridades do caso concreto e eventual necessidade de se protegerem expectativas emitidas pelo órgão jurisdicional aos demais sujeitos processuais.

Dessa forma, para quem admite a possibilidade de reapreciação de alegações quanto à ilegitimidade de parte ou falta de interesse de agir, a vedação de comportamentos contraditórios apresenta-se como uma ferramenta útil a obstar mudanças de ideia consecutivas do órgão julgador - o que para nós, frise-se, já é feito pela preclusão para o juiz, uma vez que temos a premissa de que ela se aplica a esses casos de reapreciação de questões de ordem pública processuais.

Ou ainda, no caso de exercício pelo juiz do poder de arrecadação pelo Estado, caso a serventia designe um valor de recolhimento de custas que depois seja constatado como equivocado, a inexistência de preclusão nessa hipótese permite que haja decisão determinando a complementação, mas o venire pode auxiliar vedando que o órgão julgador, ao decidir pelo complemento, puna a parte que recolheu exatamente o que lhe fora indicado (não conhecendo de um recurso, por exemplo), pois isso afrontaria as expectativas legitimamente geradas.

\subsubsection{Contradição no enfrentamento de questões não idênticas}

O segundo grupo envolve o maior número de casos em que a aplicação do venire do órgão julgador se mostra necessária. Por vezes, o juiz, ao enfrentar questões tecnicamente distintas porque não coincidentes os seus elementos identificadores, acaba por se contradizer de modo a ferir expectativas das partes. 
Basta pensar no real caso citado no Capítulo 2 supra, exemplo extraído da jurisprudência do Superior Tribunal de Justiça, segundo o qual o juiz confere prazo de suspensão do processo de noventa dias (questão 1) e, em seguida, equivocadamente publicada a sentença no curso do prazo em que o processo estava suspenso, o juiz considera transcorrido o prazo de apresentação de recurso (questão 2 ) $^{623}$.

Se considerada apenas a funcionalidade da preclusão lógica, ela somente vedaria que, depois de concedido o prazo de noventa dias de suspensão, o juízo reformasse essa decisão e deixasse de suspender o processo. Mas isso foi feito apenas implicitamente, de modo que a decisão que realmente se fez contraditória ao posicionamento anterior foi a que considerou deserto o recurso interposto. São decisões tecnicamente distintas, porquanto envolvendo outro ponto de direito, e, portanto, a segunda decisão não está vedada de ser tomada pela preclusão para o juiz, mas apenas pela vedação de decisões contraditórias em prol da proteção das legítimas expectativas dos jurisdicionados.

\subsubsection{Vedação de comportamentos contraditórios e omissões conclusivas}

No que concerne ao terceiro campo de aplicação mencionado, ainda que inadmitida a decisão por omissão, é possível que o prolongamento do tempo sem que o juízo tenha tomado uma decisão sobre determinada questão crie nas partes a legítima expectativa de que a decisão não mais será tomada, conforme já sinalizamos no item 4.2.2 supra.

Nesse contexto, precisamos analisar o caso das nulidades absolutas. Para minoritária doutrina, apoiada nos postulados da proteção da confiança processual, hipóteses de nulidade absoluta deixam de poder ser reconhecidas se transcorrido muito tempo em que existente a relação jurídico-processual sem que nada a respeito tenham alegado as partes ou tenha decidido o juiz.

Antonio do PASso CABRAL defende que essa perda do poder do juiz de conhecer nulidade absoluta após transcorrido muito tempo e criadas expectativas nas partes

${ }^{623}$ Trata-se do REsp 1306463/RS, Rel. Ministro HERMAN BENJAMIN, SEGUNDA TURMA, julgado em 04/09/2012, DJe 11/09/2012. 
de que ela não seria conhecida (o que o autor chama de "preclusão lógica do poder de decidir") vale inclusive para casos de incompetência absoluta:

\begin{abstract}
"Aqui focamos apenas a hipótese de ausência de decisão. Quando se omite em decidir no saneador, transmitindo aos demais um padrão de conduta significativo, perde o juiz, pela preclusão lógica, o poder de decidir. No que tange aos atos estatais, justifica-se a vedação de condutas incompatíveis no princípio da proteção da confiança, que atua pela estabilização das relações jurídicas, inclusive da relação jurídica processual. A proteção da confiança oferece segurança jurídica na tutela das expectativas dos sujeitos não estatais, forte na preservação das situações constantes e estáveis contra modificações jurídicas posteriores. E mesmo as chamadas 'nulidades absolutas' podem precluir por comportamento contraditório. Uma aplicação dessas idéias seria no que diz respeito à preclusão do poder judicial de declarar a incompetência absoluta depois de omissão conclusiva em sentido contrário" ${ }^{24}$.
\end{abstract}

Concordamos com as ideias do autor - porém em caráter de lege ferenda no que concerne ao caso de incompetência absoluta e os demais casos do art. 485 do CPC, como explicaremos adiante -, na medida em que, se há interesse público no resguardo das nulidades absolutas, há também na proteção da confiança por meio da boa-fé e da cooperação processual.

Em verdade, a classificação entre nulidades absolutas e relativas já é per si falha, porque carecedora de um critério seguro e suficientemente diferenciador de todos os casos em que uma nulidade é considerada absoluta ou relativa. A publicização do processo acaba por tornar cogente a grande maioria das normas processuais ${ }^{625}$, do mesmo modo que difícil identificar normas processuais que não busquem atender, igual e simultaneamente, interesses públicos e privados ${ }^{626}$.

Dessa maneira, limitar a aplicação do venire em prol do resguardo de uma nulidade absoluta pelo simples fato de o vício ser classificado como absoluto não tem razão de ser. Há de ser realizado um juízo de ponderação de valores entre o valor boa-fé resguardado pelo venire e aquele outro valor protegido pelo legislador ao impor uma específica forma para realização de determinado ato processual ${ }^{627}$.

\footnotetext{
${ }^{624}$ Nulidades no processo moderno, pp. 338-339.

${ }^{625}$ ANTONIO DO PASSO CABRAL, Nulidades no processo moderno, p. 85.

${ }^{626}$ ANTONIO DO PASSO CABRAL, Nulidades no processo moderno, p. 86. Ainda que em outro contexto, JOSÉ ROBERTO DOS SANTOS BEDAQUE também relativiza a classificação entre nulidade absoluta e relativa. Ao analisar a possibilidade de convalidação de vícios de caráter absoluto ou relativo com base na aplicação do princípio da instrumentalidade das formas e ausência de prejuízos, afirma que "a relevância desta classificação [nulidade absoluta ou relativa], todavia, é bem menor do que pretende a doutrina tradicional, pois a possibilidade de o vício ser desconsiderado, porque alcançado o fim, independe da espécie de nulidade (Efetividade do processo e técnica processual, p. 458).

${ }^{627}$ FREDIE DIDIER JR., Alguns aspectos da aplicação da proibição do venire contra factum proprium no Processo Civil, p. 204.
} 
De forma abstrata, portanto, identifica-se a possibilidade de a vedação de comportamentos contraditórios se dar tendo por factum proprium a não decisão do juiz. Se isso prevalecerá ou não no caso concreto, não há como se definir a priori, mas já há notícias de hipóteses concretas em que prevaleceu a não contradição à declaração de nulidade "absoluta" - como ilustraremos adiante.

Ressalvamos, contudo, a hipótese de o venire prevalecer sob a alegação de incompetência absoluta no atual ordenamento, uma vez que esse vício consta como uma das hipóteses em que cabível o ajuizamento da ação rescisória (art. 485, inc. II, do Código de Processo Civil). Nesse caso, assim como ocorre com os demais exemplos constantes do rol do referido artigo 485 do CPC, o legislador preestabeleceu o valor da forma a ser observada (que, por sua vez, consagra a proteção de outros valores, à luz do conceito de formalismo-valorativo ${ }^{628}$ ) em detrimento da boa-fé e da cooperação.

Em outras palavras, ao permitir que vício dessa natureza possa ser reconhecido mesmo após o trânsito em julgado, o legislador sopesou a priori qual o valor que deve prevalecer, não sendo possível que uma omissão nesse sentido do juiz provoque nos sujeitos processuais uma confiança de que o vício não mais será reconhecido - salvo, claro, após o prazo decadencial da ação rescisória, oportunidade em que o reconhecimento do vício não poderia ser feito de qualquer forma, em razão da coisa julgada, sua eficácia de sanatória geral, e a impossibilidade de rescindibilidade do julgado.

As hipóteses que justificam o cabimento da ação rescisória, portanto, não podem ser impedidas de serem alegadas por meio da aplicação do venire por omissão. Ao permitir a alegação ainda após dois anos do trânsito em julgado, o legislador criou um marco temporal certo para que essas omissões sejam possivelmente sanadas. Até o fim desse prazo, impossível que sejam criadas expectativas de que aquelas questões não mais seriam alegadas, enfrentadas e acolhidas em razão da omissão do juiz, já que os sujeitos processuais estão cientes da possibilidade de isso acontecer mesmo após a decisão final, não havendo justificativa para uma confiança em sentido contrário.

Assim, de lege lata, apesar da concordância com as ponderações feitas por ANTONIO DO PASSO CABRAL quanto ao venire e nulidades absolutas ${ }^{629}$, entendemos não

\footnotetext{
${ }^{628}$ Ver, por todos, Carlos Alberto Alvaro de Oliveira, Do formalismo no processo civil.

${ }^{629}$ Concordamos com o autor quando ele afirma que "No que tange aos atos estatais, justifica-se a vedação de condutas incompatíveis no princípio da proteção da confiança, que atua pela estabilização das relações jurídicas, inclusive da relação jurídica processual. (...) E mesmo as chamadas 'nulidades absolutas' podem precluir por comportamento contraditório. Uma aplicação dessas idéias seria no que diz respeito à preclusão
} 
haver espaço para uma confiança a ser emitida de uma "omissão conclusiva" quando o próprio sistema ressalva que, perante a omissão que se prolongue até depois do trânsito em julgado, ainda assim será possível o reconhecimento do vício em sede de ação rescisória.

O que se pode fazer desde logo, todavia, é restringir a aplicação do art. 485, inc. II, do Código de Processo Civil à luz da boa-fé objetiva e da cooperação: ainda que não seja possível extrair da simples omissão sobre o tema da incompetência absoluta a impossibilidade de reconhecê-la posteriormente, é possível que discussões travadas no curso do processo vinculem as partes e as impossibilitem de alegar incompetência absoluta mais adiante. É possível, ainda, obstar a tentativa de rescisão do julgamento com base no referido artigo caso a iniciativa seja do próprio autor, considerando contraditória a pretensão à rescisão com o próprio fato de ele ter ajuizado a demanda por iniciativa própria em local incompetente.

Vale sistematizarmos melhor a relação entre venire e hipóteses justificantes da ação rescisória. Pensando nas hipóteses de cabimento da rescisória em geral, vislumbramos três situações possíveis.

Na primeira, o processo tramita do começo ao fim sem que qualquer uma das partes alegue o vício, e também o juiz não se manifesta de ofício e, em sede de rescisória, o vício é alegado por uma das partes. Nesse caso, como inexistente comportamento anterior das partes e, segundo nosso entendimento, como não existe venire por omissão do órgão julgador nesses casos, nada impediria que a alegação fosse conhecida em sede de rescisória.

Na segunda hipótese, uma das partes alega o vício no processo originário, mas ele é expressamente afastado pelo juiz. Em sede de rescisória, então, o vício é reiterado pela mesma parte. Nesse caso, inexiste contradição alguma no comportamento da parte, de modo que sequer há espaço para se falar em venire. E, como a preclusão é fenômeno endoprocessual, o fato de o vício ter sido discutido anteriormente não impedirá nova discussão na rescisória. Nada impede, aqui, que esse vício seja alegado e acolhido pela via rescisória.

do poder judicial de declarar a incompetência absoluta depois de omissão conclusiva em sentido contrário. (...) Se todos os órgãos jurisdicionais são plenamente detentores dos poderes jurisdicionais, devem cooperar entre si e não apenas exigir colaboração dos demais sujeitos do processo." (Nulidades no processo moderno, p. 339). Mas, para que essas ideias sejam aplicadas no ordenamento, entendemos que, antes, é preciso que o legislador abandone classificações infudadas (como nulidade absoluta x relativa) e deixe de permitir que o sistema seja condescendente com essa ausência de estabilidade e possibilidade de reconhecer vícios como esse da incompetência absoluta em sede rescisória. Essa é nossa única ressalva. 
Por fim, imaginemos caso em que uma das partes alegue o vício, e ele é igualmente afastado pelo juiz. Em sede de rescisória, a parte contrária sustenta o mesmo vício. A única possibilidade de essa alegação não configurar venire é a dessa parte contrária, quando da alegação do vício no processo originário, ter concordado com ele. Se, por outro lado, ela defendeu a inexistência do vício, ou caso tenha se mantido silente, ela estará impedida de alegá-lo em sede de rescisória, pela vedação de comportamentos contraditórios - e, aqui sim, é possível se falar em venire por omissão da parte porque ela deixou de agir quando dela um comportamento era esperado, como ficará mais claro no item 8.2.1.2 infra.

No caso específico da rescisória por incompetência absoluta, a situação de comportamentos contraditórios pode se configurar com mais facilidade com relação ao autor, posto que o ajuizamento da demanda em determinado local já é considerado um factum proprium gerador de expectativas. Dessa maneira, quanto a essa específica alegação em sede de rescisória, há de se levar esse comportamento inicial do autor em conta, vedando-lhe alegar incompetência absoluta apenas porque o resultado do julgamento não lhe foi favorável.

Em síntese, portanto: defendemos que, no nosso atual ordenamento, não é possível se falar em venire do órgão julgador por omissão quando a não decisão disser respeito a uma das hipóteses justificantes do ajuizamento da ação rescisória. Isso não significa dizer, contudo, que inexiste correlação entre venire, ação rescisória e nulidades absolutas, pois, como vimos, quando a parte contradisser comportamento anterior ao alegar um vício justificante da rescisória, é possível impedi-la de tal comportamento.

Isso ilustra que a nulidade "absoluta" já não é um valor absoluto em nosso sistema, o que é também evidenciado pelo seguinte exemplo (apesar de não se tratar de hipótese de venire por omissão conclusiva): o posicionamento do Superior Tribunal de Justiça segundo o qual é válida a penhora de bem de família, ainda que seja ele absolutamente impenhorável à luz do art. 649, inc. V, do CPC, se o devedor voluntariamente indica esse bem à penhora, e isso com base na vedação de comportamentos processuais contraditórios ${ }^{630}$.

\footnotetext{
${ }^{630}$ RECURSO ESPECIAL - EXECUÇÃO - EMBARGOS À ADJUDICAÇÃO - INDICAÇÃO DE BEM À PENHORA PELO DEVEDOR - POSTERIOR ALEGAÇÃO DE NULIDADE ANTE A IMPENHORABILIDADE ABSOLUTA (ART. 649, V, DO CPC) - AFASTAMENTO DA TESE PELAS INSTÂNCIAS ORDINÁRIAS. INSURGÊNCIA DO EXECUTADO. 1. Hipótese em que o executado indica bem à penhora e, posteriormente, invoca a nulidade da adjudicação em razão da impenhorabilidade absoluta
} 
Exemplo menos polêmico de omissão conclusiva - porquanto não ligado a nulidades absolutas -, é o da não limitação, pelo juiz, na fase inicial do processo, do número de litisconsortes segundo autoriza o art. 46 do CPC. Ao deixar de exercer essa limitação, o juiz emite confiança de que o procedimento poderá seguir sem óbices, sendo vedado o rompimento dessas expectativas posteriormente, de modo a excluir litisconsorte sob a alegação de que o número excessivo deles comprometerá a celeridade do processo, quando já ultrapassada a fase saneadora ${ }^{631}$.

E ainda, vale retomar o exemplo dado no item 4.2.2 supra, acerca da não decisão sobre o pedido de gratuidade de justiça de uma parte, sendo que fora concedido o benefício a essa mesma parte em processo conexo. A omissão, portanto, emite a confiança de que em ambos os processos foi concedida a gratuidade, não podendo o órgão julgador contradizer essa confiança e passar a exigir, sem alteração fática alguma, o pagamento das custas sob o argumento de inexistir decisão implícita no ordenamento.

7.4.2.4. Vedação de contradições praticadas fora da mesma sede processual: limitação à análise micro da função jurisdicional.

Por fim, há um último espaço em que se permite invocar o venire aplicado ao órgão jurisdicional, mas esse espaço deve ser cuidadosamente delineado, para que não sejamos mal interpretados.

(art. 649, V, do CPC) do objeto da constrição, por constituir equipamento essencial ("colheitadeira") à continuidade do exercício da profissão. Inviabilidade. Bem móvel voluntariamente oferecido pelo devedor à garantia do juízo execucional. Patrimônio integrante do ativo disponível do executado. Renúncia espontânea à proteção preconizada no inciso $\mathrm{V}$ do art. 649 do CPC. Vedação ao comportamento contraditório (venire contra factum proprium). 2. Os bens protegidos pela cláusula de impenhorabilidade (art. 649, V, do CPC) podem constituir alvo de constrição judicial, haja vista ser lícito ao devedor renunciar à proteção legal positivada na norma supracitada, contanto que contemple patrimônio disponível e tenha sido indicado à penhora por livre decisão do executado, ressalvados os bens inalienáveis e os bens de família. Precedentes do STJ. 3. No caso, não há nulidade no procedimento expropriatório, porquanto, além de o bem penhorado ("colheitadeira") compor o acervo ativo disponível do recorrente/executado, este o ofertou deliberadamente nos autos da execução, de ordem a evidenciar contradição de comportamento da parte ("venire contra factum proprium"), postura incompatível com a lealdade e boa-fé processual. 4. Recurso especial desprovido. (REsp 1365418/SP, Rel. Ministro MARCO BUZZI, QUARTA TURMA, julgado em 04/04/2013, DJe 16/04/2013). Sobre o tema, ressalta-se uma vez mais o artigo de FREDIE DIDIER JR, Subsídios para uma teoria das impenhorabilidades, em que o autor enquadra na vedação de comportamentos contraditórios a conduta do sujeito que alega impenhorabilidade de bem disponível após tê-lo indicado voluntariamente à penhora.

${ }^{631}$ O exemplo é de DANIEL AMORIM ASSUMPÇÃo NeVES (Preclusões para o juiz, pp. 42-43), que, por sua vez, aplica-o como sendo hipótese de preclusão lógica do juiz. Com base nas nossas premissas, como a preclusão lógica, para a doutrina majoritária, não poderia ser decorrente de uma omissão, entendemos que o exemplo amolda-se com perfeição à vedação de comportamentos contraditórios. 
Como vimos, a preclusão tem efeitos endoprocessuais, apenas. Essa constatação, aplicada às preclusões para o juiz, implica admitirmos a impossibilidade de uma decisão judicial (que não corresponda ao dispositivo da decisão final) proferida em determinado processo vincular processos distintos, ainda que ambos tramitem entre as mesmas partes, e de maneira reunida. Em termos concretos, isso significa dizer que se o juiz concede justiça gratuita a uma das partes em uma ação possessória, por exemplo, nada impede que ele deixe de conceder o benefício para a mesma parte em uma ação de rescisão contratual conexa.

Esse tipo de contradição é mais frequente do que se imagina, principalmente porque sabemos que, ao longo da marcha processual, diferentes magistrados atuam em um mesmo processo e, por vezes, pensam de maneira distinta. Sem se preocuparem com a confiança gerada nas partes e esquecendo-se que atuam de maneira única, como representantes do mesmo Estado perante as partes, acabam por contradizerem-se, ferindo expectativas geradas anteriormente.

É por isso que também nesses casos há espaço para incidência do venire processual, ferramenta capaz de proteger a confiança rompida pelo Judiciário perante partes coincidentes em processos distintos, porém reunidos.

Aqui, entendemos por "reunidos" não os processos que necessariamente tenham tramitado conjuntamente, mas que poderiam ter tramitado por preencherem o requisito da parcial identidade entre pedido ou causa de pedir exigido para configuração de conexão ou continência ${ }^{632}$. Com essa parcial identidade, surge entre as partes a confiança de que o tratamento processual a elas conferido será igualmente similar, o que abre espaço à incidência do venire.

Note-se, todavia, que não estamos afirmando que o venire pode se dar entre quaisquer processos distintos, vinculando o Judiciário de maneira irrestrita, impossibilitando-o de decidir de maneira contraditória às decisões por ele proferidas. Uma afirmação dessa natureza pressuporia um estudo aprofundado sobre a dinâmica dos precedentes, sobre a confiança imposta por nosso sistema, para averiguar se existe essa confiança de qualquer jurisdicionado que, ao ingressar com uma demanda perante o Poder Judiciário, poderia ter justas expectativas de que a resolução do seu caso teria um destino certo, se outros semelhantes já foram julgados daquela maneira.

${ }^{632}$ Sobre o tema da relação entre demandas e, mais especificamente, sobre a conexão e continência, $c f$. CÂNDIDo Rangel Dinamarco, Instituições de Direito Processual Civil, v. II, pp. 152-165. 
Já fizemos referência ao entendimento doutrinário de haver essa confiança perante os Tribunais Superiores, configurando venire processual decisões que afrontem expectativas das partes de que seu caso seja julgado da mesma maneira que os demais sobre aquele mesmo tema. Essa afirmação parte da premissa de que as Cortes Superiores, "pelo simples desempenho de suas atribuições, geram uma legítima expectativa nos jurisdicionados que se encontrem nas mesmas circunstâncias descritas nos precedentes jurisprudenciais $^{633}$,

Por meio desse entendimento, não se prega a vedação de contradição de qualquer decisão judicial, mas apenas das Cortes Superiores por ser delas a função de uniformização de jurisprudência, o que gera expectativas de não incongruência perante os jurisdicionados. As ideias de RAFAEL SANTOS DE BARROS E SILVA são bastante pertinentes:

\begin{abstract}
"A legítima expectativa da parte, que deve ser protegida pela proibição do venire, é aquela gerada em decorrência de decisões proferidas por Cortes uniformizadoras de jurisprudência. Decerto, não é qualquer decisão proferida por essa Corte que pode gerar legítimas expectativas nos jurisdicionados, essas só podem ser identificadas a partir da prolação de vários precedentes em um mesmo sentido, de maneira a formar determinada jurisprudência. De todo modo, ainda que não exista jurisprudência - prolação de vários precedentes em um mesmo sentido - será possível identificar a legítima expectativa no jurisdicionado diante de um precedente, ainda que único, mas que tenha sido prolatado de forma unânime por um órgão que detenha competência exclusiva para apreciar determinada matéria. Entretanto, não haverá legítima expectativa se não houve prolação de julgamento emanda por uma Corte uniformizadora ou caso haja divergência interna no âmbito desta. A mera prolação de votos sem conclusão de julgamento ou a possibilidade de outro õrgão da mesma Corte proferir decisão divergente não pode servir para caracterizar a legítima expectativa necessária a ocorrência do venire. $\mathrm{O}$ momento em relação ao qual deverá ser verificada a existência ou não de uma legítima expectativa do jurisdicionado deve ser, em regra, o da propositura da demanda, devendo a alteração jurisprudencial preservar as expectativas daqueles que propuseram ações antes da decisão surpresante." ${ }^{634}$
\end{abstract}

Essas palavras traduzem ideia que parece ser coerente com nosso sistema processual relativo aos precedentes, com o equilíbrio entre independência funcional e segurança jurídica, com as expectativas que os inúmeros institutos destinados à uniformização da jurisprudência podem gerar. Todavia, a concordância convicta com tais

\footnotetext{
${ }^{633}$ Rafael SANTOS De Barros E Silva, O controle das expectativas dos jurisdicionados: impedindo o venire contra factum proprium do Poder Judiciário, p. 103. MARCELO J. LÓPEZ MESA parece ser ainda mais rigoroso, e exigir coerência dos magistrados em geral: “... no sólo los jueces no pueden contradecir sus actos anteriores en el mismo expediente, sino que no pueden contradecir el creiterio que hubieran adoptado sobre el mismo tema en casos anteriores. Ello, claro, a menos que muden de criterio, especifiquen el por qué del cambio y permanezcan fieles a éste en el futuro" (La doctrina de los actos propios: esencia y requisitos de aplicación, p. 216).

${ }^{634}$ RAFAEL SANTOS DE BARROS E SILVA, O controle das expectativas dos jurisdicionados: impedindo o venire contra factum proprium do Poder Judiciário, p. 106.
} 
ideias demandaria um estudo específico sobre o tema, estabelecendo-se uma série de premissas que extrapolam as pretensões deste trabalho.

Dessa forma, e aproveitando-nos da classificação sugerida por RAFAEL SANTOS DE BARROS E SILVA, limitamo-nos a analisar o venire inserido na análise micro da função jurisdicional, enquanto função solucionadora de conflitos subjetivamente identificados, o que se opõe à análise macro da função jurisdicional "enquanto instrumento de pacificação dos conflitos intersubjetivos" $" 635$.

Portanto, apontamos como quarto espaço para o venire aplicado à atividade do Estado-juiz a necessária coerência entre processos sob o ponto de vista micro da função jurisdicional, ou seja, quando emitida a confiança entre processos reunidos (ou que poderiam estar reunidos) e com relação a pelo menos uma das partes coincidentes ${ }^{636}$, e não baseada na confiança do sistema de precedentes ${ }^{637}$.

\subsubsection{Análise sobre preclusão, venire e um novo sistema de estabilidades}

\footnotetext{
635 RAFAel SANTOS DE BARROS E SILVA, O controle das expectativas dos jurisdicionados: impedindo o venire contra factum proprium do Poder Judiciário, p. 102.

${ }^{636}$ A exigência da coincidência de ao menos uma das partes se dá como pressuposto da existência de uma confiança a ser rompida pelo órgão julgador por meio da contradição (já que estamos tratando da contradição apenas entre conflitos subjetivamente identificados), e não como requisito da conexão ou continência.

637 Ainda em prol da aplicação da teoria de vedação de comportamentos contraditórios no campo dos precedentes, merecem destaque as palavras de NELSON NERY JUNIOR: "Essa proibição de venire contra factum proprium, que nasceu no direito privado, impõe-se à administração porque decorre diretamente do texto constitucional, pois agindo contra seus próprios atos a administração viola os princípios da segurança jurídica (CF $1^{\circ}, 5^{\circ}$ caput e XXXVI), da solidariedade (CF $\left.3^{\circ} \mathrm{I}\right)$, da legalidade e da moralidade administrativa (CF 37 caput). (...) Do ponto de vista prático, o dever de os poderes públicos - aqui incluindo o Poder Judiciário, cujas decisões são objeto deste estudo - agirem com boa-fé significa que não devem impor aos administrados e jurisdicionados sanções ou desvantagens relativamente a direitos e obrigações, fruto da modificação de seu entendimento a respeito de determinada situação ou relação jurídica. Assim, modificada a jurisprudência do tribunal, seus efeitos têm de ser para o futuro, ainda que a natureza da decisão judicial seja declaratória, como ocorre nas decisões que reconhecem a inconstitucionalidade ou ilegalidade de norma." (Boa-fé objetiva e segurança jurídica: eficácia da decisão judicial que altera jurisprudência anterior do mesmo tribunal superior, pp. 85-87). E conclui o autor: "Mesmo depois de adotado novo posicionamento do tribunal sobre determinado assunto, o tribunal deve aplicar sua jurisprudência anterior aos casos futuros que lhe sejam apresentados, mas respeitantes a fatos ocorridos na vigência da jurisprudência anterior" (Boa-fé objetiva e segurança jurídica: eficácia da decisão judicial que altera jurisprudência anterior do mesmo tribunal superior, p. 95). Nesse contexto, vale lembrarmos-nos das reflexões feitas pelo Min. Humberto Gomes de Barros no seu voto-vista proferido no AgRg no REsp 382.736/SC, Rel. Ministro CASTRO MEIRA, Rel. p/ Acórdão Ministro FRANCISCO PEÇANHA MARTINS, PRIMEIRA SEÇÃO, julgado em 08/10/2003, DJ 25/02/2004, p. 91., segundo o qual "Nas praias deTurismo, pelo mundo afora, existe um brinquedo em uma enorme bóia, cheia de pessoas é arrastada por uma lancha. A função do piloto dessa lancha é fazer derrubar as pessoas montadas no dorso da bóia. Para tanto, a lancha desloca-se em linha reta e, de repente, descreve curvas de quase noventa graus. O jogo só termina, quando todos os passageiros da bóia estão dentro do mar. Pois bem, o STJ parece ter assumido papel do piloto dessa lancha. Nosso papel tem sido derrubar os jurisdicionados.". O voto ficou informalmente conhecido como "voto banana boat".
} 
Por fim, sobre a relação entre preclusões e venire, não podemos deixar de mencionar o posicionamento de ANTONIO DO PASSO CABRAL em sua obra Coisa julgada e preclusões dinâmicas, porquanto o autor trata especificamente do tema, e sobre uma perspectiva diversa da que utilizamos neste trabalho.

O autor parte da premissa de que o sistema das preclusões tal como retratado e atrelado aos demais mecanismos processuais de estabilização das decisões é insuficiente para atender a necessidades práticas do processo, buscando-se, assim, um novo conceito de preclusão, mais amplo, e que, assim, dentre outras alterações, englobe um conceito de preclusão lógica condizente com os parâmetros da vedação de comportamentos contraditórios.

A primeira revisão do conceito de preclusão parte de uma insatisfação com as funções desempenhadas pela coisa julgada e pela preclusão tradicional, especialmente no que se refere ao fato de que elas são insuficientes para blindar o sistema de contradições lógicas; por elas não considerarem a intrínseca mutabilidade da sociedade - o que gera a impossibilidade de se regular por definitivo uma solução judicial; por somente as partes definirem o objeto a ser estabilizado, desconsiderando os interesses públicos para definição dessa qualidade; por diversos atos judiciais deixarem de adquirir qualquer estabilidade, sejam aqueles atos finais de processos que não o de conhecimento, sejam os atos observados no iter processual e que não repercutem consequências jurídicas para fora do processo. Assim, o escopo é alterar o sistema de estabilidades como um todo, o qual é visto hoje sob um formato "retrospectivo, privatista, estático, cognitivista e fracionado" $" 638$.

Fugiria às possibilidades deste trabalho revisitar todas as premissas de que parte essa nova visão das estabilidades, para apresentar a completa teorização elaborada. Para nós, é importante ressaltar que a preclusão na concepção apresentada pelo autor passa a ser defendida como o conceito amplo de estabilidade processual, abarcando o que hoje entendemos por coisa julgada e pela preclusão propriamente dita. E, ao alargar essa conceituação, o venire contra factum proprium passa a ser inserido nas hipóteses de preclusão $^{639}$.

Com efeito, desvincula-se a preclusão das amarras endoprocessuais.

\footnotetext{
${ }^{638}$ ANTONIO DO PASSO CABRAL, Coisa julgada e preclusões dinâmicas, p. 38.

${ }^{639}$ ANTONIO DO PASSO CABRAL, Coisa julgada e preclusões dinâmicas, p. 45.
} 
A limitação dos efeitos endoprocessuais da preclusão é criticada em sua base, ou seja, a partir de sua premissa. Como vimos, diz-se tradicionalmente que a preclusão não pode ter seus efeitos estendidos considerando que fenômeno semelhante só ocorre com o dispositivo da sentença, pela incidência da coisa julgada. Se nem mesmo os fundamentos da decisão final produzem efeitos para fora do processo, por uma questão de coerência sistêmica, também as preclusões não se estendem a outros processos. Essa premissa é rompida pelo autor pelo fato de que o ato final estatal não deve absorver e se sobrepor aos atos intermediários, cuja estabilidade coexiste com a da sentença final.

O autor parte da quebra de linearidade entre a prática dos atos processuais, seguindo-se pela construção do conceito de cadeias de vínculos. Segundo ele, os atos processuais não são praticados de forma cronológica e linear, de modo que nem todos são condicionantes para a decisão final e, portanto, não devem ser abarcados pela estabilidade decorrente da sentença.

A estabilidade do ato processual está ligada à sua capacidade de influenciar a decisão. Somente se tornam estáveis "aqueles atos que forem condicionantes (influência) para a formação do espaço de estabilidade resultante da cadeia que compreende a sentença de mérito." ${ }^{640}$. Exemplifica ANTONIO DO PASSO CABRAL afirmando que uma confissão sobre fato excluído do objeto de cognição, em princípio, não deve gerar nenhuma estabilidade, vez que não foi condicionante para a sentença de mérito.

Essa quebra de linearidade implica não só considerar possível que um ato pretérito não se inclua em uma cadeia de vínculos geradora de estabilidades, mas também resulta admitir que atos futuros estejam abarcados por uma estabilidade já existente ${ }^{641}$. Pensando na hipótese da confissão, se o fato sobre o qual ela recai se faz relevante em um outro processo, veda-se a contradição aos fatos confessados por ela compor uma cadeia de vículos própria, e com efeito preclusivo ulterior incidente aos atos futuros $\operatorname{condicionados}^{642}$. A cadeia de vínculos, frise-se, se dá não de maneira cronológica ou espacialmente limitada, configurando-se uma cadeia própria, sem dependência de uma sentença, sempre que atos processuais tiverem a capacidade de se influenciarem ${ }^{643}$.

\footnotetext{
${ }^{640}$ ANTONIO DO PASSO CABRAL, Coisa julgada e preclusões dinâmicas, p. 333.

${ }^{641}$ ANTONIO DO PASSO CABRAL, Coisa julgada e preclusões dinâmicas, p. 334.

${ }^{642}$ ANTONIO DO PASSO CABRAL, Coisa julgada e preclusões dinâmicas, p. 335.

643 "No formato aqui sugerido, como não há linearidade e não existe uma só fonte originante da estabilidade, os espaços estáveis coexistem antes, durante e depois do processo. Os atos posteriores não estão excluídos da cadeia de vínculo, e caso nela se incorporem, p.ex., por pretenderem efeitos incompatíveis com a estabilidade
} 
As ideias são bastante instigantes, principalmente por inserir nosso objeto de estudo em um cenário muito mais amplo e puramente processual, evitando os inconvenientes a que o próprio autor se refere de transpor uma figura pensada pelo Direito Civil para o Processo. Especificamente quanto ao venire, sustenta que a mentalidade privatista acaba por impedir o uso adequado da figura em âmbito processual, requerendose, para tanto, a identidade subjetiva, a demonstração de dano, além de impedir a aplicação ao magistrado, requisitos que não se coadunam com as necessidades do processo ${ }^{644}$.

Todavia, não podemos negar o caráter inovador das premissas estabelecidas pelo autor, premissas apresentadas após uma série de quebras de paradigmas. Caso todas elas sejam acolhidas futuramente, o venire passa a se inserir nesse amplo sistema de estabilidades.

Por ora, porém, como sabemos o quanto ideias inovadoras são discutidas e repensadas antes de se tornarem a regra comum, temos o intuito menos ambicioso de justamente transpor de maneira adequada a figura do venire para o Processo, o que implica quebra de algumas poucas premissas, tarefa muito mais tímida.

Esse item é ilustração pura do quanto é preciso que as premissas sobre o que seja preclusão estejam bem fixadas para que seja possível fazer qualquer comparação com o nemo postest venire contra factum proprium. E buscamos demonstrar que, mediante a prevalência das ideias atuais, as figuras não se identificam em sua inteireza. Entretanto,

gerada, deverão ser inadmitidos." (ANTONIO DO PASSO CABRAL, Coisa julgada e preclusões dinâmicas, p. 336).

${ }^{644}$ Fiéis às palavras do autor, destacamos: "Em primeiro lugar, institutos como o abuso de direito, a proibição do venire contra factum proprium e a Verwirkung, dentre outros, possuem forte base doutrinária e tradição privatista, da qual constantemente os processualistas não conseguem se libertar. Para a aplicação do nemo potest venire contra factum proprium, p.ex., exige-se que haja identidade subjetiva, enquanto que isso nem sempre ocorre com as estabilidades processuais. A utilização da boa-fé como fundamento autônomo para um vínculo processual sugeriria, na visão de alguns autores, que tal vinculação formar-se-ia apenas entre as partes, não compreendendo o juiz. Então como justificar a vinculação dos juízos posteriores ao decidido? Entende-se ainda que muitos dos institutos derivados da boa-fé, como a proibição do venire contra factum proprium, não atingem poderes do juiz. Enquanto isso, é muito mais significativa e crescente a tendência de admitir maiores preclusões para os poderes do magistrado. Tomemos ainda o seguinte exemplo: numa demanda, é alegada incompetência do juízo por haver compromisso arbitral firmado; posteriormente, acolhida a objeção e iniciada a arbitragem, a mesma parte argui nulidade do contrato arbitral, afirmando que a questão deve ir ao Judiciário, em evidente contradição comportamental. Muitos autores, apegados a noções civilistas, negam a aplicação do nemo potest venire contra factum proprium neste caso sob os argumentos, ou de que uma 'alegação' não corresponderia propriamente a uma 'declaração de vontade', ou porque não há consequências negociais do comportamento incompatível. É, de fato, comum, a referência a um prejuízo ou da possibilidade de um dano patrimonial dentre os requisitos para aplicação da proibição do venire contra factum proprium. Portanto, temos que, enquanto não houver uma mudança de mentalidade, faz-se necessário um afastamento de institutos moldados no direito privado" (ANTONIO DO PASSO CABRAL, Coisa julgada e preclusões dinâmicas, pp. 310-311). 
nada impede que sejam alterados todos os preceitos fundamentais de que partimos e, a partir disso, que se torne impossível diferenciar preclusão e venire. 


\section{APLICAÇÃO DO VENIRE AO PROCESSO}

Após o estudo de tantos temas tangenciais - mas imprescindíveis para o desenvolvimento de nosso objeto de estudo -, chega o momento de consolidarmos tudo o quanto foi exposto, de fazermos as conexões necessárias para que consigamos chegar à conclusão deste trabalho. A tarefa é desafiadora, principalmente porque não se tem notícia de um estudo aprofundado cujo objeto primordial seja a compreensão do comportamento processual contraditório.

Contamos com a essencial contribuição de trabalhos doutrinários que, na maioria das vezes, na forma de $\operatorname{artigos}^{645}$ e itens de livros ${ }^{646}$, tratam brevemente da figura do venire aplicada ao processo. Tentaremos consolidar, organizar e classificar essas ideias, de modo a auxiliar na compreensão do que representa a contradição afrontadora da boa-fé ao processo. Certamente, não faltarão críticas às ideias expostas; mas isso significará que semeamos a reflexão sobre o tema, o que já é suficientemente satisfatório.

A primeira ressalva a ser feita na tentativa de estruturar uma teoria sobre o comportamento processual contraditório é a de que o fenômeno adquire proporções mais extensas quando comparado com a sua observância no Direito Civil. No Processo Civil, a peculiaridade de o Estado se fazer presente na relação jurídica processual, bem como em razão de ser o processo uma ciência instrumental, traz diferenciações diversas, tanto no tocante aos elementos necessários à configuração do instituto, quanto às suas consequências.

\footnotetext{
${ }^{645}$ FREDIE DIDIER JR., Multa coercitiva, boa-fé processual e suppressio; GUSTAVO PRAZERES, Venire contra factum proprium nulli conceditur e direito processual; FREDIE DIDIER JR., Alguns aspectos da aplicação da proibição do venire contra factum proprium no Processo Civil; LUIZ MARINONI e DANIEL MITIDIERO, Propriedade intelectual. Boa-fé objetiva. Proibição do venire contra factum proprium no processo. Dever de não conhecer do recurso; PEDRO NOGUEIRA, Notas sobre preclusão e venire contra factum proprium; JORGE PEYRANO, La doctrina de los propios actos en el ámbito del procedimiento civil; JULIO CHIAPPRINI, La doctrina de los propios actos: errores; FRANCESCO CARRETTA MUÑOZ, Deberes procesales de las partes en el proceso civil chileno; RAFAEL SANTOS DE BARROS E SILVA, O controle das expectativas dos jurisdicionados: impedindo o venire contra factum proprium do Poder Judiciário; TALITA ROMEU, $O$ princípio da boa-fé e o instituto da preclusão: a suppressio processual; LUIZ RODRIGUES WAMBIER, A suppressio e o direito à prestação de contas; FREDIE DIDIER JR., Tópicos sobre a última reforma processual (dezembro de 2006): (parte 1);

${ }^{646}$ MARIANA PRETEl E PRETEl, A boa-fé objetiva e a lealdade no processo civil brasileiro, pp. 143-164; OSVALDO GOZAÍNI, La conducta en el proceso, pp.205-221; MARIO MASCIOTRA, La conducta procesal de las partes, pp. 131-138; MARCELO MESA e CARLOS VIDE, La doctrina de los actos propios, pp. 154-158; ANTONIO DO PASSO CABRAL, Coisa julgada e preclusões dinâmicas, pp. 127-136, 309-313 e 463-464; ANTONIO DO PASSO CABRAL, Nulidades no processo moderno, pp. 307-343; LEIDE MARIA GONÇALVES SANTOS, Boa-fé objetiva no processo civil, pp. 201-228.
} 
Assim, buscaremos tratar dessas peculiaridades, para melhor aclarar as possíveis consequências da adoção de comportamentos processuais contraditórios, e sob a observância de quais requisitos tais consequências devem ser aplicadas. Com isso, tem-se por escopo melhor compreender o instituto para que ele seja uma ferramenta útil a atingir suas finalidades, evitando-se aplicações distorcidas, e que acabem por prejudicar os escopos do processo.

Metodologicamente, é preciso esclarecer que optamos por não dividir totalmente a análise do venire das partes com relação ao venire do órgão julgador, porque os fenômenos possuem mais semelhanças do que diferenças entre si. Em verdade, houve receio de que, com uma análise diferenciada, as atenções fossem voltadas apenas para as diferenças, quando não se pode olvidar que a finalidade de se vedar a contradição é sempre a mesma: proteger a confiança gerada no curso da relação jurídica processual. Dessa maneira, somente se fará essa divisão nos itens que tratarem das peculiaridades de cada figura.

\subsection{Conceito e pressuposto fundamental: análise valorativa objetiva}

A primeira premissa a ser firmada é a de que, da mesma maneira em que ocorre no Direito Civil, no Processo Civil a vedação da contradição de comportamentos processuais somente se torna relevante se, justamente em razão da contradição, são feridas as expectativas amparadas pelo sistema processual, notadamente as expectativas que decorrem da necessária observância, pelos sujeitos do processo, dos princípios da boa-fé objetiva e da cooperação. Sem afronta a expectativas processuais, não há contradição a ser vedada, de modo que a afronta às expectativas processuais de boa-fé e cooperação se posicionam como primeiro requisito essencial à vedação de comportamentos contraditórios processuais $^{647}$.

\footnotetext{
${ }^{647}$ Esse é o critério fundamental para que não haja aplicação distorcida do instituto, como alertam JORGE PEYRANO e Julio ChIAPPINI: "Por ello es, entonces, que insistimos en que los magistrados deben abstenerse de incurrir en el tema en todo tipo de apresuramiento, y así deben evitar utilizar como argumento dirimente a cualquier conducta incoherente de las partes. Caso contrario, se confundiría la paja con el trigo y una doctrina nacida del vientre del principio de la buena fe, se transformaría en una especie de monstruo inicuo capaz de echar por tierras las razones del justiciable a quien lo respalda el ordenamiento jurídico pero que tuvo la desdicha de cometer algún pequeño desliz que podría dar asidero a que su autor pudiera ser calificado como "incoherente"' (Informe sobre la doctrina de los propios actos en el campo procesal, pp. 682-683).
} 
Disso decorre que somente uma análise valorativa do caso concreto permitirá concluir pela ruptura ou não de expectativas e, consequentemente, somente com base em cada caso será possível averiguar se necessária a reprimenda à contradição.

Esse fator, de extrema relevância ao nosso estudo, é o que o torna tão complexo. Afinal, defender uma necessária análise casuística é quase uma contradição com a tentativa de sistematização.

Daí a imprescindibilidade de se analisar a jurisprudência sobre o tema, porque é de fundamental importância o papel das decisões judiciais para identificar casos em que comumente são feridos os princípios processuais por meio da contradição, o que permite uma tentativa de sistematização, sempre sem qualquer escopo exaustivo, porque, por mais que se quisesse esgotar todas as possíveis contradições contrárias à boa-fé e à cooperação, a tentativa seria falha diante das incontáveis possibilidades de condutas a serem praticadas nos mais diversos tipos de processo.

Essa análise valorativa do caso concreto, porém, prescinde da perquirição de qualquer elemento subjetivo: a contradição é analisada objetivamente, a partir do contexto em que as condutas foram praticadas, sem investigar se o agente quis ou não se contradizer e, com isso, romper expectativas. Lembremos que o embasamento jurídico do venire é principalmente a boa-fé objetiva, o que, no campo processual, traduz-se em um padrão de conduta processual esperado por terceiros, independentemente das intenções do sujeito ${ }^{648}$.

Assim, a análise partirá da interpretação da primeira conduta do agente, em seu sentido objetivo, se ela foi capaz de emitir confiança. Após isso, verificar-se-á a conduta contraditória também de maneira objetiva, se ela foi capaz, sob os olhos de terceiros, de ferir expectativas geradas, a despeito da intencionalidade do agente. Se a resposta for positiva, configurado está o venire processual ${ }^{649}$.

\footnotetext{
648 “La definición no se aparta de lo explicado en la exposición general: también en el proceso, la doctrina del propio acto interpreta conductas, objetivamente consideradas. De acuerdo al momento del proceso donde se suscite la contradicción, habrá que encontra el origen del comportamiento sistemático para enfrentarlo con el incoherente y resolver así, la aplicación del principio. De este modo, volvemos a recordar las distintas alternativas que pueden suceder. V.gr.: conduta precedente extraprocesal con una actuación contraria en el proceso, sea en su promoción, o al asumir la defensa; comportamientos distintos dentro del proceso; actitudes diferentes en procesos diversos, pero vinculados por algún presupuesto. Todas ellas ocasionan, a su vez, la posibilidad de interponer el principio como fundamento de una pretensión, como excepción o defensa, o como argumento de prueba" (OSVALDO GOZAÍNI, La conducta en el proceso, pp. 212-213).

649 "Note-se que, como decorre da boa-fe objetiva, a análise da incompatibilidade entre os atos prescinde da verificação das intenções. A contradição ao factum proprium deve ser buscada comparando o sentido objetivo do comportamento inicial (gerado pela confiança legítima) e o resultado empírico objetivado com a conduta posterior." (ANTONIO DO PASSO CABRAL, Nulidades no processo moderno, p. 321).
} 
Haverá condutas processuais que, objetivamente analisadas, serão incapazes de gerar quaisquer expectativas. Basta pensar na hipótese em que, por equívoco, é protocolada em um processo a defesa referente a outra demanda. $O$ endereçamento a juízo diverso, a referência ao nome de outras partes, tudo isso não permitirá que se crie a confiança, perante o órgão judicial ou a parte adversa, de que aquela era a defesa daquele caso.

Também será incapaz de gerar quaisquer expectativas a contradição acerca de fatos irrelevantes ao julgamento da demanda. No exemplo abordado no item 6.4. supra, a contradição da alegação acerca de quem foi ao caixa eletrônico, se a própria autora ou seu marido, era irrelevante ao julgamento e, por isso, incapaz de ferir quaisquer expectativas $^{650}$. Outra seria a realidade se esse mesmo fato fosse essencial ao julgamento, tal como em uma demanda sobre seguro de veículo, em que a autora mentisse sobre quem conduzia o veículo quando do sinistro com receio de não ter cobertura para casos de acidentes provocados sob a condução de terceiros.

Esses exemplos ilustram o quanto a análise valorativa do caso concreto é fundamental para que se possa falar em venire. Até porque, muitas vezes, a contradição será permitida pelo sistema processual, tal como ocorre no que diz respeito à regra da eventualidade, tema que será abordado separadamente no item seguinte.

Outro caso bastante comum que impede que haja quebra de expectativas quando da prática de comportamento contraditório posterior é aquele em que, quando da prática da conduta vinculante, já se ressalva a possibilidade de alteração de posicionamento. Isso é muito comum nos casos de decisões judiciais, como, por exemplo, quando o juízo determina a especificação de provas, porém ressalvando que ainda não descartada a possibilidade de julgamento antecipado da lide. É plenamente compreensível que, a partir da justificativa de produção de provas pelas partes, o juízo entenda que a dilação probatória é, na verdade, dispensável, porquanto os fatos que se prentende provar já estão suficientemente demonstrados.

\footnotetext{
650 "Habida cuenta, entonces, de que - al fin y al cabo - lo que persigue la doctrina de los 'propios actos' es reprimir y desalentar la incoherencia en los comportamientos cargados de sentido jurídico, se nos ocurre positivo aprovechar sus postulados para erradicar las conductas procesales incoherentes; esto último en el marco de las atribuciones judiciales, y todo con expreso subrayado acerca de que la recepción del venire contra factum involucra de alguna manera la ampliación del horizonte ético y el ingreso de una porción de derecho de equidad" (JORGE PEYRANO, La doctrina de los propios actos en el ámbito del procedimiento civil, p. 222).
} 
Assim, a ressalva quando da prática do factum proprium é um mecanismo extremamente eficiente para evitar a incidência do venire, como melhor se abordará no item 8.6. infra.

Em resumo, a análise valorativa objetiva é fundamental para que se possa falar em venire processual. A tarefa de valorar o caso concreto, porém, tornar-se-á cada vez menos complexa conforme a jurisprudência for identificando casos típicos de venire, em que a afronta à boa-fé e à cooperação processual é manifesta.

\subsubsection{Regra da eventualidade}

Optamos por tratar do tema da regra da eventualidade de maneira destacada por se tratar de exemplo mais evidente no campo processual em que a contradição é, em regra, permitida. Pela regra da eventualidade, resumidamente, impõe-se o ônus ao réu de apresentar em um momento processual único todas as teses de defesa, ainda que sejam incompatíveis entre si, sob pena de preclusão ${ }^{651}$. Mas isso significa dizer que qualquer contradição em sede de defesa deve ser tolerada, impossibilitando qualquer reprimenda?

\section{Um importante trabalho desenvolvido por MARCELA REgINA PEREIRA CÂMARA} sobre o tema específico dos limites à regra da eventualidade já nos indica que não, e com base em premissas com as quais concordamos e que se coadunam com o tema da presente dissertação. Segundo a autora, e em breve síntese, seria contrário aos princípios processuais da probidade ${ }^{652}$, do contraditório em seu sentido colaborativo e da igualdade ${ }^{653}$

\footnotetext{
${ }^{651}$ CÂNDIDo Rangel Dinamarco, Instituições de Direito Processual Civil, v. III, p. 488.

652 "A contestação ou as exceções que veiculem defesas incompatíveis, declarações inverídicas ou distorções intencionais dos fatos exprime, em verdade, a adoção de comportamento ímprobo por parte do demandado, comportamento esse que nada tem de eventual, pois não é apto a demonstrar a possibilidade ou a probabilidade de o fato alegado na petição inicial ter ocorrido de maneira oposta àquela apresentada" (MARCEla REgina PEREIRA CÂMARA, Os limites da defesa incompatível à luz da eventualidade, p. 76).

${ }^{653} \mathrm{O}$ argumento da violação da igualdade é especialmente convincente: segundo a autora, se o autor tem que apresentar compatibilidade lógica entre fatos narrados e pedido (art. 295, inc. II, CPC), bem como compatibilidade entre pedidos cumulados (art. 295, inc. IV, CPC), siginificaria afronta à isonomia permitir ao réu manter descompromisso com qualquer compatibilidade quando da apresentação de sua narrativa e seus contra-ataques. Com base nisso, afirma a autora que " se a argumentação contraditória havida na petição inicial leva à sua inépcia, e consequente indeferimento, do mesmo modo, e atendendo ao tratamento materialmente isonômico exigido como garantia constitucional do processo, a argumentação contraditória havida na contestação, além de não poder ser alicerçada na regra da eventualidade, não é apta a gerar pontro controvertido e ensejar instrução probatória" (MARCELA REGINA PEREIRA CÂMARA, Os limites da defesa incompativel à luz da eventualidade, p. 51).
} 
permitir que todas as contradições possam ser exercidas pelo réu quando do exercício de sua defesa.

A permissividade da concentração de defesas contraditórias tem a mesma premissa de todo e qualquer comportamento das partes, qual seja, de que ele deve se pautar na boa-fé, e que deve contribuir para os escopos do processo, sem desviar de suas finalidades. A essência da eventualidade está em permitir a formulação de argumentos que, apesar de incompatíveis em uma primeira leitura, não deixem de ser verossímeis e capazes de afastar a tese do autor ${ }^{654}$. Uma vez cumprida a eventualidade observando-se os limites da probidade, a regra visa inclusive a privilegiar a boa-fé, evitando-se que teses defensivas sejam maliciosamente escondidas para serem utilizadas em momentos desfavoráveis ao autor, bem como para não serem alteradas a cada momento, impedindo o prosseguimento regular do processo ${ }^{655}$.

Alegar teses diversas e que se mostrem absolutamente incompatíveis entre si, porém, foge a essa finalidade, e passa a significar uma tentativa despropositada de atravancar o processo, de fazer com que o juiz tenha que considerar defesas infundadas, contribuindo, assim, para a demora injustificada da resolução do conflito.

Resta-nos, buscar, portanto, como identificar essas defesas incompatíveis a não serem toleradas - especificando-se em que medida há a afronta à boa-fé, uma vez que a regra, aqui, é que a contradição é permitida -, bem como quais as medidas cabíveis para afastá-las.

O grande problema da regra de eventualidade em confronto com a compatibilidade lógica está, em primeiro lugar, na apresentação de defesa direta e indireta ao mesmo tempo, configurando situação em que, de um lado, o réu negue simplesmente a existência de um fato e, de outro lado, adote a existência desse mesmo fato como premissa para apresentar a existência de fatos extintivos, modificativos ou impeditivos do direito do autor $^{656}$. Tal conduta extravaza os limites da incompatibilidade permitida pela regra da eventualidade, significando, pois, o desvio de finalidade na utilização dela.

\footnotetext{
${ }^{654}$ MARCEla Regina Pereira CÂMARA, Os limites da defesa incompatível à luz da eventualidade, p. 73.

${ }^{655}$ Carlos Alberto Alvaro de Oliveira, Do formalismo no processo civil, p. 232. O autor, contudo, não elenca apenas fatores positivos da regra da eventualidade, defendendo que ela é "ao mesmo tempo garantia e obstáculo a um processo justo", por também deixar de fora argumentos omitidos não de maneira culposa pela parte ré, mas que podem ter se tornado relevantes apenas após o momento preclusivo (Ibidem, p. 232).

${ }^{656}$ Essa situação de contradição já foi vedada pela Corte de Apelação de Santiago, conforme noticia FRANCESCO CARRETTA MuÑOZ, Deberes procesales de las partes en el proceso civil chileno, p. 122.
} 
Da mesma maneira, significa abuso da regra da eventualidade a apresentação de defesas indiretas simultaneamente, mas que não possam ser faticamente possíveis de coexistirem. Como exemplo, podemos citar o réu de demanda desconstitutiva de contrato de empreitada cumulada com perdas e danos que afirma duas linhas argumentativas incompatíveis: exceção de contrato não cumprido porque já concluíra todos os serviços e não obtivera o respectivo pagamento, e contraditoriamente, ausência de inadimplemento porque ainda estava no prazo acordado para a conclusão das obras.

O nosso sistema não se conforma com a apresentação de qualquer defesa, uma vez que exige certos requisitos para que atinja a finalidade por ela almejada, tal como impõe o ônus de impugnação específica: via de regra, ausente a impugnação específica, a defesa por negativa geral é interpretada tal como se não houvesse sido apresentada a defesa, desconsiderando-a para fins de controvérsia dos fatos. O mesmo destino deve ser dado à defesa logicamente incompatível, tornando-a incapaz de descreditar as alegações do autor como um todo ${ }^{657}$.

Assim, defesas que não podem conviver simultaneamente, por não ser possível que sejam todas logicamente verdadeiras ${ }^{658}$, não devem ser admitidas, não encontrando respaldo nem mesmo na regra da eventualidade porque ela não serve de escudo ao comportamento contrário à boa-fé.

O juiz, então, deverá analisar a defesa em conjunto, de modo a definir que "somente aqueles argumentos que não se excluam mutuamente por ilogicidades ou contradições serão capazes de controverter os fatos e fundamentos jurídicos da pretensão deduzida" ${ }^{, 59}$, envitando que alegações ilógicas e de intuito proletatório atinjam sua finalidade distorcida: a de trazer mais demora ao processo.

Feita essa análise e concluindo-se pela impossibilidade de duas teses defensivas, uma direta e outra indireta, conviverem logicamente entre si, o juiz desconsiderará a defesa direta como apta à produção de seus efeitos esperados, tornando

\footnotetext{
${ }^{657}$ As ideias são de MARCEla REgINA PEREIRA CÂMARA: "Nesse sentido é de se concluir que a norma que rege o ônus de impugnação específica dá ênfase à boa-fé processual justamente ao negar qualquer efeito à contestação puramente genérica, ou seja, deve ser interpretada no sentido de que não basta que os fatos sejam impugnados de forma imprecisa, como também não podem ser impugnados por meio de argumentos logicamente incompatíveis e, portanto, destituídos de fundamento" (Os limites da defesa incompatível à luz da eventualidade, p. 145).

${ }^{658}$ Trata-se de incompatibilidade fática, apenas, pois a apresentação de defesas de direito incompatíveis é naturalmente limitada e valorada pelo princípio jura novit curia. Nesse sentido, $c f$. MARCELA REGINA PEREIRA CÂMARA, Os limites da defesa incompatível à luz da eventualidade, p. 201.

${ }^{659}$ Marcela Regina PEREIRA CÂMARA, Os limites da defesa incompatível à luz da eventualidade, p. 165.
} 
incontroversos os fatos alegados pelo autor, impondo automaticamente ao réu o ônus de demonstrar os fatos extintivos, modificativos ou impeditivos de seu direito. Da mesma maneira, a apresentação de defesas indiretas incompatíveis permite ao juiz considerar como efetiva defesa aquela que mais favorece a parte adversária, no exercício de uma valoração do comportamento do réu que permite a construção de uma presunção nesse sentido, em favor do autor ${ }^{660}$.

Dessa forma, tem-se na eventualidade um exemplo nítido do quanto a análise valorativa do caso concreto é essencial, pois somente a conclusão pela ruptura ou não da boa-fé e da cooperação será capaz de diferenciar em que medida a contradição será ou não admitida.

\subsection{Situações jurídicas processuais: os comportamentos contraditórios}

Para além da quebra de expectativas processuais, a serem objetivamente analisadas, impõe-se como segundo requisito para a configuração do venire processual a existência de condutas processuais contraditórias, justamente por meio das quais serão rompidas as expectativas existentes. Em outras palavras, por meio de uma conduta inicial é gerada a confiança de boa-fé e cooperação, a qual deve ser rompida por uma conduta ulterior a fim de que se possa falar em venire processual. E vimos que as condutas, no processo, são, via de regra, as situações jurídicas processuais ou a omissão no exercício delas.

Com base no breve estudo das situações jurídicas processuais supra realizado (Capítulo 4), deve-se indagar, portanto, se o exercício de todas elas, bem como o nãoexercício delas, é capaz de gerar expectativas processuais, ou seja, se de todas elas pode ser originado um factum proprium processual, e ainda, se todas elas podem servir como ato contraditório posterior. Indaga-se, ainda, se somente as situações jurídicas processuais são capazes de gerarem expectativas no processo.

\footnotetext{
${ }^{660}$ MARCEla Regina PEREIRA CÂMARA, Os limites da defesa incompatível à luz da eventualidade, p. 265. A autora propõe como sanções à apresentação de defesa incompatível: "a ineficácia da contestação por incompatibilidade lógica ou ética; a rejeição e ausência de produção de efeitos das alegações de evidente improcedência; a inépcia da contestação, e concessão da tutela de evidência, com a imediata produção de efeitos da sentença proferida" (Os limites da defesa incompatível à luz da eventualidade, p. 275).
} 
Conforme já ressaltamos, as partes e o juiz atuam de forma distinta, porquanto assumem papéis diversos a serem desempenhados no processo. Em razão disso, imperioso concluir que há peculiaridades na caracterização do venire para as partes com relação a contradição entre condutas do juiz, o que justifica a divisão desse item.

Ainda em caráter genérico, porém, algumas observações devem ser feitas.

Em primeiro lugar, estando no campo da análise das situações jurídicas processuais, presume-se que são todos comportamentos permitidos pelo ordenamento processual, sem que configurem ilícitos processuais, ocorrência que, se verificada, dispensaria a incidência do venire. Assim, a primeira ressalva quanto aos comportamentos passíveis de gerarem contradições a serem reprimidas é a de que eles devem ser lícitos, permitidos pelo sistema na medida em que seus agentes são os titulares das posições jurídicas exercidas, pois, do contrário, tal como ocorre no Direito Civil, a repressão a eles se daria pela vedação genérica à ilicitude.

Ligada a essa afirmação, nossa segunda ressalva é a de que a ideia de "espaço de manobra" exposta quando do estudo do abuso do processo é relevante para delimitar as possíveis condutas a ensejarem contradição a ser reprimida. Sem que o sujeito processual tenha liberdade para escolher pelo exercício ou não de uma situação jurídica processual, não é possível que desse comportamento decorram expectativas. Assim, também na seara processual são excluídos da categoria de fatos próprios e condutas contraditórias ulteriores aqueles comportamentos exigidos por lei ou por determinação da autoridade judicial, pois, sem a possibilidade de o sujeito processual adotar conduta diversa, as consequências desse comportamento não são a ele imputáveis.

Isso porque, nesses casos, a opção é inexistente, vez que o não exercício da conduta faria com que o sujeito desrespeitasse as normas positivadas ou o comando judicial, de modo que eventual confiança rompida pela contradição a esse fato vinculado não gera situação de aplicação de venire, mas apenas ilícitos processuais: a contradição aqui corresponderia à afronta à determinação legal ou judicial.

Passa-se, então, às peculiaridades da contradição entre condutas das partes e a decorrente da atuação do Estado-juiz.

\subsubsection{Contradição das partes}


Retomando, tem-se como situações jurídicas das partes as faculdades, poderes, ônus, deveres e sujeições. Considerando a premissa de que é preciso liberdade de atuação para gerar expectativas, dessas situações processuais excluem-se os deveres e as sujeições como aptas a gerarem confiança: quando do exercício de um dever, age-se em prol do interesse alheio, sem liberdade de atuação, de modo que a inobservância de um dever implica um ilícito processual, sem que disso decorram expectativas a serem protegidas. Da mesma maneira, quando da sujeição a parte sequer pode atuar, certamente não sendo possível gerar expectativas de qualquer conduta comissiva. Mas também essa omissão não pode gerar expectativas, já que ela se deu não pelo livre arbítrio, mas pela impossibilidade de atuar de maneira diversa.

Como exemplo, pode-se imaginar caso em que a parte mantém-se inerte em razão de uma decisão judicial nesse sentido, decisão que determinou, por exemplo, a suspensão do processo por certo lapso temporal. Essa inércia da parte vinculada à decisão judicial não pode servir de factum proprium por omissão, já que a parte não tinha condições de agir de maneira diversa, sem que desse ato emanem expectativas que não o simples cumprimento da ordem judicial.

Entretanto, vimos que são raras as hipóteses de deveres e sujeições processuais. Em verdade, a principal situação jurídica processual é o ônus, que, por ser caracterizado pela liberdade de atuação, uma vez exercido pode gerar expectativas a serem tuteladas, o que vale também para o exercício de faculdades e poderes.

\subsubsection{Contradição entre comportamentos e sede processual}

Com relação à atuação das partes, uma peculiaridade deve ser ressaltada quanto ao factum proprium: ele é o próprio comportamento processual em sentido amplo, que, por sua vez, pode ser divido entre (i) o exercício das situações subjetivas processuais e (ii) os atos praticados pelas partes que sejam externos ao processo, mas que venham a nele produzir efeitos.

Uma pergunta anteriormente realizada consiste em averiguar se necessário que a contradição se dê entre condutas praticadas dentro de um mesmo processo para que se 
configure um fenômeno de interesse processual. E a resposta é negativa: para que seja caracterizado o que denominamos de venire processual, é relevante apenas que a contradição se dê no processo, ou seja, que haja ruptura de expectativas processuais.

Para tanto, é imprescindível que o segundo comportamento, aquele responsável por frustrar expectativas, seja praticado no processo e seja qualificado como ato processual propriamente dito. Já o primeiro ato, aquele gerador de expectativas, pode ter sido praticado (i) dentro do mesmo processo em que houve a prática do ato contraditório; (ii) dentro de uma sede processual diversa, i.e., em outro processo, anterior ou conexo; (iii) ou até mesmo fora de qualquer sede processual.

Excluem-se, portanto, apenas as contradições decorrentes de um ato primeiro e um ato contraditório posterior, ambos praticados fora de qualquer sede processual. Nessa hipótese, o fenômeno é de interesse apenas do Direito Civil, e, no limite, será apenas reconhecido por meio de um processo ulterior, servindo o processo como veículo para a simples pronúncia do reconhecimento do venire material, sem que tenham sido afrontadas expectativas processuais propriamente ditas, já que sequer existente um processo quando da contradição.

A explicação para essa conclusão não poderia ser mais elementar: considerando que a finalidade de se vedar condutas processuais contraditórias é proteger legítimas expectativas processuais, somente essas expectativas sendo rompidas no processo, o fenômeno adquire relevância processual. E haverá ruptura dessa confiança quando a contradição se der no processo. Já o ato anterior, aquele gerador de expectativas, pode ter sido praticado em qualquer sede, processual ou não, desde que devidamente comprovado nos autos como ato existente e capaz de gerar efeitos, de gerar expectativas processuais.

$\mathrm{Na}$ análise jurisprudencial realizada, foram indicados exemplos de cada uma dessas espécies de contradição. Para relembrarmos, pensemos como hipótese de contradição observada inteiramente na sede processual qualquer caso de contradição de alegações, como nos Embargos de Declaração no Agravo de Instrumento n. $1318082^{661}$, em que a parte impugna a qualidade técnica do perito que, em momento anterior, houvera elogiado.

\footnotetext{
${ }^{661}$ EDcl no Ag 1318082/SP, Rel. Ministro LUIS FELIPE SALOMÃO, QUARTA TURMA, julgado em 10/04/2012, DJe 16/04/2012.
} 
Para ilustrar um caso de confiança rompida a partir de conduta exercida em processo anterior, pensemos no Recurso Especial n. 605687, em que a parte expressamente permitira exposição de seu detalhamento de ligações na ação de inexibilidade de débito e, na ação indenizatória, passou a alegar que esse fato expôs sua intimidade ${ }^{662}$.

E, por fim, quanto à confiança gerada por um ato praticado fora de qualquer sede processual, basta vislumbrar situações em que a compra de bem de relevante valor de mercado tenha sido feita momentos antes do ingresso da parte em um processo no qual, posteriormente, ela requer a gratuidade da justiça. Ou ainda, casos em que alegações feitas no processo contrariam aquelas reconhecidas pela própria parte em atos praticados fora de qualquer processo, como em uma confissão de dívidas.

A contradição com base em conduta primeira praticada fora do processo, e conduta posterior processual, pode despertar consequências também materiais. Não é a primeira vez que um mesmo fenômeno interessa igualmente ao direito material e ao direito processual. Atos como a renúncia, a transação e a confissão, provocam efeitos materiais e também processuais e isso se verifica pela existência de um suporte fático coincidente tanto para normas jurídicas processuais quanto para as substanciais.

Tanto isso é verdade que há quem estenda o conceito de ato processual àqueles que apenas gerem efeitos no processo, sendo prescindível que sejam praticados na sede processual ou por sujeitos processuais.

Tradicionalmente, é classificado como ato processual aquele praticado por um sujeito processual, no curso de um processo, e destinado a produzir efeitos no processo, conforme conclui CÂNDIDO DINAMARCO após expor a imprescindibilidade desses três elementos ${ }^{663}$.

Ocorre que alguns autores entendem como suficiente apenas que o ato produza efeitos no processo ${ }^{664}$, independentemente, portanto, de serem praticados no curso do

${ }^{662}$ REsp 605687/AM, Rel. Ministra NANCY ANDRIGHI, TERCEIRA TURMA, julgado em 02/06/2005, DJ 20/06/2005, p. 273.

663 "Da convergência dos elementos necessariamente presentes no ato processual emerge a conceituação deste como conduta humana voluntária, realizada no processo por um dos seus sujeitos e dotada da capacidade de produzir efeitos sobre este" (Instituições de Direito Processual Civil, v. II, pp. 484-485).

${ }^{664} \mathrm{Na}$ verdade, é possível identificar mais de duas correntes sobre o tema, conforme expõem FREDIE DIDIER JR. e PEDRO NOGUEIRA: "Pode-se arrumar a divergência doutrinária em quatro correntes: a) alguns entendem que é suficiente o produir efeitos no processo para que o ato seja havido como processual; b) há quem o vincule aos sujeitos da relação processual: apenas o ato por eles praticado poderia ter o qualificativo de processual; c) há também os que exigem tenha sido o ato praticado no processo, atribuindo à sede do ato especial relevo; d) há quem entenda que ato processual é o praticado no procedimento e pelos sujeitos 
processo, fora dele ou até mesmo antes que ele seja instaurado ${ }^{665}$. Relevam, ainda, que sejam praticados por sujeitos processuais.

A despeito da existência dessa discussão quanto aos atos processuais, o que nos interessa é que a contradição seja afrontadora de expectativas processuais. Isso significa dizer que a contradição precisa se dar por comportamentos dos sujeitos processuais, bem como precisa emergir dentro de uma sede processual, de modo a afrontar expectativas processuais, o que exige que ao menos o segundo comportamento seja processual, sendo irrelevante a qualificação do primeiro como processual ou não.

Para tanto, exige-se apenas que esse factum proprium extraprocessual se refira a um procedimento em aberto, pois, do contrário, ele sequer adquiriria relevância para o mundo jurídico processual. E isso ainda que sua ocorrência tenha se dado previamente à abertura da sede processual, desde que, quando da existência do processo, aquele ato anteriormente praticado seja relevante, capaz de gerar expectativas processuais ${ }^{666}$.

Muitas vezes, os atos exteriores ao procedimento são nele noticiados por meio das alegações das partes, o que nos faz indagar se o factum proprium seria o ato em si ou a alegação da existência do ato ${ }^{667}$. A questão resolve-se com facilidade se considerada a

processuais (conceito mais amplo do que o de sujeitos da relação processual)" (Teoria dos fatos jurídicos processuais, pp. 29-30).

${ }^{665}$ Nesse sentido, destacam-se as palavras dos seguintes autores: "O ato jurídico ganha o qualificativo de processual quando é tomado como fattispecie (suporte fático) de uma norma jurídica processual e se refira a algum procedimento. Esse ato pode ser praticado durante o itinerário do procedimento ou fora do processo. A 'sede' do ato é irrelevante para caracterizá-lo como processual" (FrEDIE DidIER JR. e PEDRo NOGUEIRA, Teoria dos fatos jurídicos processuais, p. 31); "Ha vários fatos, relevantes para o processo, de possível ocorrência fora do processo, mas com inegáveis interferências no desenrolar do procedimento e na própria relação jurídica processual (v.g., a morte de uma das partes; a transação, que pode gerar a responsabilidade patrimonial do terceiro adquirente etc). Para isso, preferimos adotar uma definição mais abrangente, que evite o incoveniente de tratar vários fatos de inegável relevância para o processo como marginais ao fenômeno processual” (PEDRO NOGUEIRA, Situações jurídicas processuais, p. 758); “Ato processual é aquele que gera efeitos dentro do processo sobre matéria processual. Não importa que o ato se aperfeiçoe fora dele. $\mathrm{O}$ relevante é que os efeitos do seu aperfeiçoamento sejam sentidos dentro do processo, sob o ponto de vista do direito processual nele discutido" (BERNARDO SILVA DE LIMA, Sobre o negócio jurídico processual, p. 117).

${ }^{666}$ Nas palavras de Fredie Didier e Pedro NogueIRA, "todo fato processual há de pressupor um procedimento a que se refira, ainda quando sua ocorrência seja exterior, isto é, fora da 'sede' processual. Essa contemporaneidade entre o fato e o procedimento não significa simultaneidade, por ser possível a não coincidência cronologicamente falando, dos dois elementos" (Teoria dos fatos jurídicos processuais, p. 58).

${ }^{667}$ Há reflexões sobre o tema na obra de FREDIE DIDIER e PEDRO NOGUEIRA: "Também não poderíamos considerar que tais atos ou fatos, exteriores ao procedimento, seriam 'integrados' ao procedimento pelo ato de alegação das partes no processo quanto à sua ocorrência; tal integração, por força da alegação, promoveria a sua integração ao procedimento, mas os efeitos processuais decorreriam do ato (alegação) praticado dentro do processo. Vale dizer, os fatos extraprocedimentais (v.g. a morte de uma das partes), de per si, não seriam processuais, pois não se estaria a tratar de uma eficácia imediata, mas se integrariam ao procedimento pela alegação, no processo, de sua ocorrência. Essa alegação, estando obviamente inserida no procedimento e, sendo, dessa maneira, um ato processual, é que teria relevância para o processo". (Teoria dos fatos jurídicos processuais, p. 33). 
finalidade da vedação de comportamentos contraditórios, qual seja, a proteção da expectativa gerada a partir do comportamento processual. Se a expectativa originou-se diretamente da prática do ato, este é o factum proprium a ser considerado. Se, por sua vez, foi a alegação da parte no processo que fez surgir a expectativa, ela corresponde ao factum proprium, que se deu processualmente e não de maneira extraprocessual.

A contradição das partes, portanto, pode se verificar a partir da comparação entre condutas praticadas dentro de um mesmo processo, ou ainda, com base em uma primeira conduta praticada em outro processo ou até mesmo fora de qualquer sede processual. O que se faz imprescindível é a ruptura de expectativas processuais ${ }^{668}$.

Tudo isso revela um dos principais motivos, já elencado, pelo qual o venire não se confunde com a preclusão lógica, diante da frequente limitação imposta pela doutrina dos efeitos desta às barreiras endoprocessuais. Se um dado comportamento foi praticado em um determinado processo, pela preclusão lógica pura e simplesmente, não haveria qualquer limitação de esse agente se contradizer em processo ulterior. Pior: como a preclusão lógica é fenômeno endoprocessual, comportamentos praticados fora da sede do processo sequer teriam relevância jurídica à luz desse instituto.

Frise-se que, a depender da premissa do que se entenda por preclusão, caso conferida a ela um caráter bem mais amplo como o faz ANTONIO DO PASSO CABRAL, seria possível inserir essa funcionalidade do venire dentro do conceito de preclusão. Mas, como não é essa a visão majoritária da doutrina, optamos por diferenciar as figuras para deixar claro que a vinculação de um comportamento à luz da boa-fé e da cooperação processual se extende para além das barreiras de uma mesma sede processual ${ }^{669}$.

\footnotetext{
${ }^{668}$ Corroborando nosso entendimento, destaca-se: "No obstante ello, la conducta anterior o llevada a cabo fuera del proceso, muchas veces puede servir para tener por acreditados comportamientos incoherentes o contradictorios de las propias partes, una vez abierta la instancia, pero aquí - si bien la diferencia es sutil estaríamos frente a la llamada prueba de 'intercadencia', como manifestación de la teoría de los actos propios. Es decir, se podría acreditar la incoherencia o contradicción de una de las partes, a través del análisis comparativo del comportamiento desplegado durante el curso del proceso y el desarrollado fuera de él. Así, por ejemplo, si la conducta contradictoria de una parte se manifesta en procesos diferentes y existe relación entre ambos, como ocurriría si en un accidente de tránsito, una de las partes reconoce su culpabilidad en la justicia represiva y luego en la justicia civil manifiesta lo contrario al absolver posiciones, esta autocontradicción, aun cuando se deduzca de procesos diferentes, debe ser tomada en su contra como manifestación de sus 'propios actos'. Lógicamente, para que ello suceda el expediente penal debe ofrecerse como prueba documental e incorporarse al proceso civil.” (MISAEL E. ALBERTO, Valor probatorio de la conducta en juicio, p. 133).

${ }^{669} \mathrm{Em}$ verdade, o próprio autor, antes de estender o conceito de preclusão na obra Coisa julgada e preclusões dinâmicas, entendia a preclusão como fenômeno endoprocessual, invocando a funcionalidade do venire para suprir os casos de contradição para além das barreiras processuais: "Se os atos forem praticados dentro de um mesmo processo, isso pode ser operado pela ocorrência da preclusão lógica porque o fenômeno da preclusão limita-se, temporal e espacialmente, pela litispendência. Caso algum dos atos incompatíveis tenha sido
} 
E não há nenhuma interpretação sistemática das normas processuais que impeça essa vinculação extraprocessual, o que não é realidade para a preclusão lógica. Como vimos, para muitos, considerando a funcionalidade primordial da preclusão, ligada ao impulso da marcha processual e à segurança jurídica, de modo a por um fim em discussões incidentais no processo, seria incoerente com o sistema atual de imutabilidade, pela coisa julgada, apenas do dispositivo e não dos motivos da decisão, impor efeitos extraprocessuais ao que foi discutido e ultrapassado no curso do processo.

Contudo, como o objetivo aqui é tutelar a confiança, i.e., as expectativas decorrentes da boa-fé processual e da cooperação, não há necessária fidelidade à extensão dos efeitos da coisa julgada material, que possui finalidade diversa. Dessa maneira, condutas praticadas em outro processo ou mesmo fora da sede processual são igualmente capazes de vincular as partes, estendendo-se essa vinculação para os locais em que houver contradição violadora de expectativa a ser tutelada.

Não só não há impedimentos sistemáticos para se chegar a essa conclusão, mas também há elementos que permitem corroborar o que afirmamos. Basta pensar no já citado artigo 348 do atual Código de Processo Civil, que entende por confissão aquela feita tanto judicial quanto extrajudicialmente, permitindo, pois, que comportamento extrajudicial ou fora de uma mesma sede judicial adquira relevância jurídica e possa vincular a conduta da parte.

\subsubsection{Contradição e omissão conclusiva}

Ainda com relação às situações jurídicas das partes, fixamos no item 4.1.3. supra que a omissão é muito mais do que um nada jurídico.

Inicialmente, com relação à omissão de um dever ou de uma sujeição, não vislumbramos outras consequências jurídicas além daquelas naturalmente impostas. No caso da sujeição, como vimos, sequer é esperado qualquer comportamento da parte, de modo que sua inércia é a consequência natural esperada, sem que disso possam ser extraídas quaisquer expectativas. No que se refere ao dever processual, como a conduta é

praticado fora do processo ou em processo diverso, a contradição entre os comportamentos poderá ser invalidade ou inadmitida por aplicação do nemo potest venire contra factum proprium." (ANTONIO DO PASSO CABRAL, Nulidades no processo moderno, p. 313). Esse é um exemplo claro de que a relação entre preclusão lógica e venire pode ser diversa, a depender sempre das premissas a serem adotadas. 
imposta, a omissão representa ilícito processual a ser sancionado, sem que seja preciso se utilizar do venire para tutelar a situação de eventual quebra de confiança. De todo modo, sendo as hipóteses de deveres processuais bastante restritas, limitando-se, no mais das vezes, a justamente o dever de agir conforme a lealdade e a boa-fé, a quebra desse dever é justamente o que vem sendo por nós estudado, ou seja, a configuração do venire, por romper com a boa-fé, significa afronta de um dever.

Já com relação às situações jurídicas processuais ativas, utilizaremo-nos da expressão de ANTONIO DO PASSO CABRAL segundo o qual as omissões com relação a elas podem ser "conclusivas", qualidade que, para nós, é atingida quando a inércia é capaz de gerar a expectativa de que aquela situação jurídica não mais será praticada, à semelhança do que acontece com a suppressio do Direito Civil. Trata-se, portanto, de uma omissão geradora de expectativa, de modo que um comportamento comissivo posterior não possa rompê-la, sob pena de violação da boa-fé processual objetiva e da cooperação.

Para nós, esse é o mecanismo inspirador da norma prevista pelo artigo 245 do Código de Processo Civil, direcionado às nulidades a serem alegadas pelas partes. Apesar de não se tratar de venire, e sim de preclusão - por causa da característica de subsidiariedade do venire a que faremos referência no item 8.4. infra -, a imposição de alegação de nulidade na primeira oportunidade tem como pressuposto implícito o fato de que, passada essa primeira chance, seria gerada a confiança de que para a própria parte prejudicada aquela nulidade não foi relevante, de modo que sua omissão em arguí-la não possa mais romper essa confianção por arguição ulterior.

O que deve ser ressaltado, entretanto, é que não basta o simples decurso de tempo para que surja uma confiança a ser tutelada pela vedação de comportamentos contraditórios. Caso se buscasse vedar a simples inércia no processo por um determinado lapso temporal, seria suficientemente eficiente a fixação de prazos e consequente imposição da preclusão temporal.

Nesse ponto, inclusive, justifica-se porque o venire por omissão não se dá quando existente a fixação de prazo que, uma vez inobservado, enseja a preclusão temporal. Enquanto pendente a existência de um prazo processual preclusivo, não é possível que se emita qualquer confiança ${ }^{670}$, já que o sistema deixa claro que, dentro daquele prazo, a liberdade de atuação não é irrestrita. E, transcorrido o prazo, a vedação de

${ }^{670}$ ANTONIO DO PASSO CABRAL, Nulidades no processo moderno, p. 326. 
conduta posterior comissiva já é vedada pela preclusão temporal, sendo desnecessário e até atécnico se falar em venire.

Em verdade, explica-se por esse mesmo motivo o fato de a omissão não poder ser relativa a um ônus processual, vez que a não desincumbência de um ônus, como vimos no item 7.2. supra tem por consequência fundamental a preclusão. A contradição à omissão de um ônus por uma conduta comissiva posterior já é vedada pela preclusão aplicada às partes, seja pela preclusão temporal, seja pela preclusão lógica - que, para nós, é a concretização expressa de exemplos de vedação de comportamentos contraditórios já valorados pelo legislador.

Todavia, e complementando a ideia anterior, nos casos em que não há prazo preclusivo cominado para o exercício de determinada conduta processual, e, mais precisamente, nos casos de situações jurídicas processuais puramente ativas (poder e faculdade), é preciso buscar parâmetros mais objetivos que nos permitam qualificar uma omissão como afrontadora de boa-fé ou não. E, como não basta apenas a omissão-inércia, é preciso algo além: faz-se necessário que sejam analisadas as circunstâncias do caso concreto, de modo a se aferir que, podendo agir, por diversas vezes, e sendo exigível a atuação, porquanto conduta esperada de qualquer homem médio, a parte mantém-se inerte.

Note-se, assim, que se trata de uma omissão observada em meio a circunstâncias que indicam que, inicialmente, o esperado era a parte agir. Quando a parte deixa de agir conforme o esperado, prolongando-se nessa omissão por mais tempo, pode-se falar em confiança de que aquela conduta não mais será exercida. E há essa expectativa inicial de que a parte agirá em determinado sentido porque a conduta comissiva seria aquela que a privilegiaria, por se tratar de uma posição jurídica de vantagem.

Por esse motivo é que são raras as hipóteses de venire processual por omissão (ou, para os que preferirem, suppressio processual), já que, ao falarmos em expectativa inicial de atuação, estamos falando de casos em que, em geral, a parte vai agir comissivamente, seja para aferir a vantagem decorrente de um poder, seja pela maior conveniência a ser observada no exercício de uma faculdade.

Em resumo, para que haja venire processual por omissão, é preciso: (i) que se trate de uma posição jurídica de vantagem (não sendo, pois, ônus, dever ou sujeição); (ii) que a parte tenha se mantido inerte quanto ao seu exercício e (iii) que as circunstâncias 
indiquem que a conduta esperada, à luz da boa-fé, era justamente o exercício dessa posição, o que permitirá se falar em omissão geradora de expectativas a serem tuteladas por meio da vedação à contradição.

Com a retomada dos exemplos já citados, será possível tornar essas ideias mais claras.

O exemplo marcante trazido por FREDIE DIDIER JR. ${ }^{671}$ diz respeito à inércia da parte em noticiar em juízo o descumprimento de uma obrigação da parte adversa para ver acumular a multa coercitiva imposta a fim de estimular o adimplemento. Ou seja, o primeiro comportamento da parte, aquele factum proprium gerador de expectativas, foi o pedido do cumprimento da obrigação pela parte adversa. O segundo comportamento contraditório é justamente a omissão em não denunciar o não cumprimento da prestação imposta, para gerar o acúmulo de astreintes.

Nessa hipótese, há de se impor a perda do exercício da posição processual correspondente à execução de multa diária porque, violando a boa-fé objetiva, o credor permaneceu inerte, visando ao aumento do montante da multa, quando já poderia tê-la executado a fim de coagir o devedor a prestar a obrigação que deveria ser a única de seu interesse $^{672}$.

O exemplo dado corrobora o fato de que, além da simples inércia da parte, houve omissão de um poder processual quando o esperado, à luz da boa-fé, era agir, noticiando ao juízo o descumprimento para que outras medidas pudessem ser impostas em prol do adimplemento, verdadeiro objetivo a ser perseguido na execução.

O outro exemplo por nós referido diz respeito à ausência de manifestação da parte quanto à pendência de um recurso por ela interposto, quando o esperado era ter se manifestado nesse sentido. Para relembrarmos, a parte interpusera recurso, porém ele nunca chegou a ser juntado aos autos. E, não obstante todo o processamento do recurso da parte adversa (perante o Tribunal de Justiça e o Superior Tribunal de Justiça), nunca houve manifestação da primeira recorrente senão quando do início de cumprimento definitivo de

${ }^{671} \mathrm{O}$ exemplo é tratado no já referido artigo Multa coercitiva, boa-fé processual e supressio: aplicação do duty to mitigate the loss no processo civil.

672 “Ao não exercer a pretensão pecuniária em lapso de tempo razoável, deixando que o valor da multa aumente consideravelmente, o autor comporta-se abusivamente, violando o princípio da boa-fé. Esse ilícito processual implica a perda do direito ao valor da multa (supressio), respectivamente ao período de tempo considerado pelo órgão jurisdicional como determinante para a configuração do abuso de direito. Trata-se, pois, de uma um ilícito processual caducificante" (FREDIE DIDIER JR., Multa coercitiva, boa-fé processual e supressio: aplicação do duty to mitigate the loss no processo civil, p. 48). 
sentença. O Tribunal, assim, decidiu pela caracterização da suppressio, a parte perdera o direito ao julgamento do recurso ( $c f r$. item 2.8.8. supra).

Também nessa hipótese, mais do que a mera omissão, houve inércia quando esperado que a parte agisse, porquanto a ação era imperiosamente de seu interesse. A omissão, portanto, foi conclusiva, na medida em que gerou expectativas de que, após a não atuação quando esperado, o prolongamento da omissão fez transparecer que a parte não mais exerceria o direito.

E, respondendo à indagação feita em momento anterior e ainda pendente, entendemos ser esse um caso de verdadeiro venire por omissão uma vez que, além de presentes seus requisitos configuradores, não há no sistema processual outro mecanismo de vedação dessa conduta contrária à boa-fé. A invocação do artigo 245 do Código de Processo Civil, nesse caso concreto, parece impertinente na medida em que se trataria de nulidade passível de cognição de ofício e, assim, a preclusão seria relativizada à luz do parágrafo único do mesmo artigo.

A análise dos dois exemplos já anteriormente invocados reforça a ideia de que a hipótese de venire por omissão é exceção em nosso sistema, pois não tratamos de outros exemplos justamente por não terem sido muitos os encontrados ${ }^{673}$. Pelos motivos já expostos - de se exigir uma inércia qualificada por uma não atuação prolongada no tempo e que, inicialmente, traduzia-se em situação em que o esperado era agir -, o venire por omissão acaba sendo pouco configurado na prática, o que não é de modo algum negativo. Pelo contrário, é imprescindível que as consequências da omissão sejam cuidadosamente delineadas, para que não convivamos em um mundo em que nossas não-atuações sejam constantemente interpretadas e supervalorizadas a despeito de nossa vontade.

Isso, contudo, não significa dizer que esgotadas as potencialidades de aplicação do venire por omissão. Pelo contrário, as potencialidades são tão incontáveis quanto a

\footnotetext{
${ }^{673}$ Pode-se citar como caso de venire por omissão, ainda, a tentativa da Fazenda Pública de interpor Recurso Especial quando deixara de interpor recurso voluntário de apelação, como ilustra o entendimento do Superior Tribunal de Justiça: "PROCESSUAL CIVIL - REEXAME NECESSÁRIO - AUSÊNCIA DE APELAÇÃO DO ENTE PÚBLICO - INADMISSIBILIDADE DO RECURSO ESPECIAL - PRECLUSÃO LÓGICA. 1. A jurisprudência da Seção de Direito Público, em recente julgado, reafirmou o entendimento de que é inadmissível recurso especial contra acórdão proferido em sede de reexame necessário, quando ausente recurso voluntário do ente público, dada a ocorrência da preclusão lógica. 2. Recurso especial não conhecido. (REsp 1052615/SP, Rel. Ministra ELIANA CALMON, PRIMEIRA SEÇÃO, julgado em 14/10/2009, DJe 18/12/2009)." Apesar da referência à preclusão lógica, como o comportamento inicial foi uma omissão, entendemos que, à luz da concepção de preclusão trazida pela doutrina majoritária, era o caso de se falar em venire. Não importa, porém, a nomenclatura utilizada, o que importa é a compreensão do fenômeno como sendo de tutela de expectativas geradas por uma omissão da parte.
} 
vivência de cada processualista na vida prática forense. Caberá, então, à jurisprudência identificar esses novos casos e assim contribuir para a completude do estudo ora realizado.

8.2.1.3. Os sujeitos das situações jurídicas em contradição: remetentes e destinatários da confiança

No item anterior, buscamos delimitar quais situações jurídicas passíveis de serem exercidas pelas partes permitem a configuração da contradição processual afrontadora da boa-fé e da cooperação, sejam situações comissivas, sejam omissivas.

Nessa oportunidade, enfrenta-se o tema deixado em aberto quanto aos diversos sujeitos parciais e a possibilidade de, por condutas praticadas por diferentes sujeitos, serem rompidas expectativas processuais (identidade de remetentes das expectativas), bem como se é preciso que os comportamentos em contradição se deem perante uma mesma parte (identidade de destinatários da confiança).

Iniciando o estudo sobre a ótica do sujeito ativo da contradição, via de regra, o mesmo sujeito que praticou a conduta inicial geradora de expectativas é quem deve se contradizer. Afinal, não há efetivamente uma contradição afrontadora de confiança se sujeitos distintos agem em contrariedade: pelo contrário, é da realidade processual, por exemplo, que autor e réu aleguem realidades contraditórias. Assim, em um plano inicial de raciocínio, faz-se necessária a identidade de parte para que se possa falar em afronta à confiança: a mesma parte deve agir de modo a gerar expectativas e, em seguida, agir contrariamente de modo a romper essas mesmas expectativas.

Todavia, a transposição desse raciocínio de direito privado - ressalvando-se que, como vimos, naquela seara o requisito de identidade de partes é também mitigado para a realidade do processo revela que é impreciso se falar em identidade de parte, sendo mais adequado exigir a identidade de sujeitos atuando no mesmo polo de interesse.

Sem que seja possível nos aprofundarmos quanto ao estudo da relação jurídica processual, tema, per si, espinhoso, é fato que, nela, a parte é quase sempre auxiliada, minimamente, por um procurador, e que outros sujeitos podem ingressar na lide para também auxiliar na defesa de seus interesses, como o faz o assistente técnico e até mesmo o assistente como modalidade de intervenção de terceiros. 
Nesses casos, é possível se concluir que há uma atuação conjunta, em que todos visam aos mesmos objetivos, ao mesmo resultado da lide, de modo que o alinhamento de expectativas entre eles permite que suas condutas sejam vistas, pela parte adversa e pelo Estado-juiz, como uma só conduta para fins de emissão de expectativas. Isso permite, pois, que uma conduta inicial seja praticada por um desses sujeitos e que a contradição, posteriormente, se dê pelo comportamento de um outro sujeito dentro desse mesmo polo de interesse.

Em casos de litisconsortes ou de outras modalidades de intervenção de terceiros, porém, nem sempre a atuação lado a lado significará convergência de interesses. Por vezes, essa convergência será parcial, de modo que somente nessa parcela é que será possível haver contradição por meio de condutas de diferentes sujeitos. Será preciso, portanto, à luz do caso concreto, identificar se a contradição se deu no exercício de condutas convergentes, pois, do contrário, não haverá que se falar em confiança rompida.

Com relação aos sujeitos passivos da contradição da conduta das partes, ou seja, os destinatários da confiança, parece-nos que a concepção pode ser mais abrangente, inexigindo-se que a conduta inicial e a contradição sejam exercidas perante a mesma parte.

Isso é relativizado, em primeiro lugar, pelo fato de não só a parte adversa ser prejudicada em razão da contradição afrontadora da boa-fé, mas também o próprio órgão julgador. Assim, de imediato, se pensarmos em contradições observadas em uma mesma sede processual, minimamente dois destinatários serão simultaneamente afetados.

Além disso, ainda que a conduta contraditória se dê em comparação com aquela praticada em outro processo ou fora da sede processual, a parte que tenha tido conhecimento dessa conduta inicial, ainda que não seja aquela perante a qual o comportamento vinculante foi exercido, pode alegar venire processual sempre que a contradição se der em face dela.

Como exemplo, pensemos em uma demanda judicial de interdição promovida por "A" contra "B", sendo que "A" e "B" são cônjuges. "A" pretende interditar "B" sob o argumento da prodigalidade, e, para corroborar a falta de discernimento de "B", "A" alega que "B" foi fiador em um contrato de locação. Anos depois, "B" é réu em ação de cobrança de aluguéis como fiador. "A”, então, opõe embargos de terceiro afirmando que não prestou outorga para a fiança, pois sequer sabia da existência do contrato, requerendose a anulação do pacto fidejussório. Certamente o autor da ação de cobrança pode usar a 
afirmação feita por "A" na ação de interdição se dela tiver conhecimento, ainda que não tenha sido parte na ação de interdição.

E isso principalmente porque, não podemos nos olvidar, em ambas as demandas houve a atuação do Estado-juiz como sujeito processual, de modo que a confiança perante ele foi criada, e não pode ser simplesmente desfeita por meio da ruptura de expectativas processuais.

Em resumo, portanto, a identidade ativa se dá entre partes inseridas em um mesmo polo de interesse e a identidade passiva, por sua vez, é bastante mitigada, principalmente pela existência do órgão julgador como sujeito processual coincidente.

\subsubsection{Contradição do órgão julgador}

Com relação às situações jurídicas do órgão julgador, vimos que elas se resumem aos poderes-deveres, bem como à omissão no exercício deles.

Já fixamos que, para a caracterização do venire processual, fundamental que as condutas em contradição tenham sido exercidas com "espaço de manobra". No caso da atuação do Estado-juiz, certamente existe esse espaço quando da atividade decisória, o que para alguns diz respeito à discricionariedade do juiz, para outros, trata-se da liberdade interpretiva. O que importa, para nós, é o reconhecimento de que, quando o juiz exerce seu poder-dever decisório, no momento final ou no curso do processo, há diversas hipóteses a fim de se atingir a única solução possível, e a escolha por esses caminhos revela o "espaço de manobra" do magistrado.

Assim, quando da tomada de decisões, o juiz pode contradizer-se de modo a ferir expectativas geradas nos demais sujeitos processuais.

Todavia, observamos oportunamente que muitas dessas contradições já são vedadas pelo sistema em observância do fenômeno da preclusão para o juiz: antes de que haja risco da contradição, o simples fato de uma questão já ter sido decidida impede que o juiz reaprecie aquele ponto. Assim, o espaço de incidência do venire para o juiz, sob o ponto de vista micro da função jurisdicional, é menor.

Não é, contudo, inexistente. 
Como vimos, há quatro grupos de situações em que há espaço para se falar em vedação de condutas contraditórias do órgão jurisdicional, uma vez que, nesses casos, a preclusão não consegue, per si, vedar todas as possíveis contradições. São eles: (i) no campo das exceções à preclusão para o juiz; (ii) quando, pelo enfrentamento de questão não idêntica, o órgão jurisdicional acaba por contradizer decisão anterior; (iii) para proteger legítimas expectativas extraídas da não-decisão, ou seja, da omissão e (iv) em casos de confiança rompida pelo Judiciário perante partes coincidentes em processos distintos, porém reunidos.

Nessas hipóteses, a configuração do venire se dará tal como ocorre com relação às partes: haverá uma primeira conduta decisória do órgão julgador ou uma omissão prolongada capaz de emitir expectativas nos demais sujeitos processuais; em seguida, se, por um ato decisório posterior, o juiz se contradisser rompendo essa expectativa, surge espaço para incidência de vedação de comportamentos contraditórios do órgão julgador.

O primeiro grupo pouco trará utilidade para o estudo de venire, principalmente porque o interpretamos de maneira restrita, sendo bem poucos os casos em que, para nós, a preclusão para o juiz é exceção no sistema e não poderá resolver o problema concreto, na medida que defendemos que até mesmo as questões de admissibilidade, condições da ação e pressupostos processuais, uma vez decididas, não podem ser simplesmente reapreciadas.

O segundo grupo concentra a maior potencialidade de aplicação de venire ao órgão julgador, porquanto frequente que, na apreciação de questões não tecnicamente idênticas, haja contradição do juiz. Já citamos o exemplo da suspensão do processo por prazo de noventa dias e posterior julgamento de deserção do recurso interposto confiando nesse prazo de suspensão. Além desse, pode ser indicado o exemplo a ser abordado a seguir quanto a decisões contraditórias sobre a possibilidade de parcelamento do pagamento das custas periciais: para uma das partes, houve deferimento do pedido a partir da consulta à opinião do perito, mas, analisando posteriormente o pedido da parte adversa, com relação à outra prova pericial, o mesmo pedido de parcelamento foi indeferido sem sequer ouvir se o perito concordava com o parcelamento.

O terceiro grupo, como vimos, diz respeito ao venire por omissão do órgão julgador, as chamadas "omissões conclusivas". Dessa maneira, se não há decisão por omissão em nosso sistema, uma vez que isso fere o princípio da motivação das decisões judiciais, é possível se falar em confiança pela omissão, pois, em determinado contexto, a inércia é capaz de produzir expectativas nas partes. 
Para a análise de quais situações ensejam a configuração de omissão conclusiva, porém, não podemos deixar de refletir sobre a confiança imposta pelo próprio sistema, o que muito dificulta a configuração de venire por omissão do órgão julgador sem torná-la, contudo, inexistente.

Quando o sistema indica que decisões tardias, ou seja, fora do momento adequado, são possíveis, é defeso às partes criarem expectativas em sentido contrário. É o que defendemos, conforme já afirmado, no caso de ausência de manifestação quanto à incompetência absoluta no curso de todo o processo, pois o sistema processual indica que ainda assim é possível o reconhecimento do vício após o trânsito em julgado, por meio da via rescisória. Não vemos como, com base nisso, as partes alegarem que, a despeito dessa possibilidade, elas confiaram que o vício não mais seria reconhecido por causa da omissão do juiz: o sistema processual, ao prever essa hipótese como caso de rescisória, não permite que seja formada confiança nas partes nesse sentido.

Há muitos casos, porém, em que o sistema nada diz acerca do prazo para reconhecimento de nulidades absolutas - pelo contrário, elas em tese têm prazo indefinido para seu reconhecimento, porém o sistema deixa de garantir qualquer marco temporal certo em que isso ainda é possível -, hipóteses em que cabível se falar em omissões conclusivas do órgão julgador. Além disso, os casos de venire do juiz por omissão não se resumem à decretação de nulidades, e, ao contrário, podem dizer respeito a quaisquer outras questões não resolvidas no processo, desde que defensável a tese de que se confiou que aquela decisão não mais seria tomada, o que deve ser sustentado com base nas circunstâncias de cada caso concreto.

Um exemplo que nos vem à mente é caso em que, tratando-se de relação de consumo, o juiz não se atenta à vedação prevista no artigo 88 do Código de Defesa do Consumidor, e permite a denunciação da lide providenciada pela empresa fornecedora ré. A litisdenunciada ingressa nos autos, apresenta contestação, o consumidor autor apresenta réplica, e assim se desenvolvem os demais atos processuais. Será defeso ao juiz, posteriormente, excluir a litisdenunciada do polo passivo para fazer valer o artigo 88 do CDC, pois sua conduta omissiva no sentido da exclusão foi capaz de gerar expectativas em todos de que, naquele caso, a denunciação fora definitivamente admitida.

O quarto grupo pensamos ter sido suficientemente explicado no item 7.4.2.4. supra. Trata-se de hipótese em que o órgão julgador emite decisões contraditórias em processos distintos, porém que contêm contexto fático em comum, o que enseja nas partes 
a confiança de que serão tratados similarmente - lembrando-se do corte metodológico quanto à análise micro da função jurisdicional, sem considerar a expectativa de que casos similares sejam julgados similarmente em um contexto macro.

Uma ressalva especial deve ser feita com relação a esse quarto grupo: por se tratar de processos distintos, em tese, as preclusões não produzem efeitos de um processo para o outro. Assim, é possível que nesse caso a contradição se dê mediante apreciação de questões idênticas, cuja reapreciação não é obstada pela preclusão em razão de seus efeitos exclusivamente endoprocessuais. O venire, portanto, cumpre a função exercida pela preclusão de obstar apreciação diversa de questões idênticas quando é preciso tutelar a confiança entre processos, além de poder, é claro, vedar contradição entre questões não idênticas e também entre processos distintos.

Se com relação às partes o requisito da identidade do sujeito ativo já foi mitigado, o tema sequer adquire relevância no que diz respeito ao venire aplicado às decisões judiciais: não importa qual a identidade física do juiz que exerceu conduta inicial e posterior contradição, uma vez que eles não atuam com pessoalidade e sim como representantes do Estado como um todo. Assim, perante os demais sujeitos processuais, representam um único polo, desinteressado e imparcial, agindo, pois, com unidade de identidade sempre.

Dessa forma, é irrelevante se um magistrado proferiu decisão inicial e outro analisou questão diversa e, nessa análise, agiu em contradição com expectativa anterior: perante o jurisdicionado, houve atuação de um único órgão, a quem é imputada indistintamente a contradição.

Com relação à identidade passiva, o tema seria bastante complexo, não fosse a nossa limitação metodológica de analisar o venire do órgão julgador apenas sob o ponto de vista micro da função jurisdicional.

Assim, conforme já salientamos, para que se possa falar em venire do órgão julgador nos limites do nosso trabalho, é preciso que a contradição tenha ocorrido dentro de uma mesma sede processual, ou ainda, em processos que preencham os requisitos necessários a uma possível conexão (ainda que na prática, não tenham efetivamente tramitado em conjunto). Observadas essas circunstâncias, não precisa haver identidade de destinatários da decisão, pois, uma vez proferida uma determinada decisão, ela é capaz de 
gerar confiança a todos os sujeitos processuais, ainda que ela se destine a apenas uma das partes.

Exemplificando: em um processo que tramita perante "A" e "B", inicialmente foi necessário que se produzisse uma prova pericial requerida por " $A$ ", sendo ele, portanto o responsável por arcar com as custas processuais. "A" estava em situação financeira delicada, requerendo ao juízo que os honorários periciais fossem parcelados. O juiz consultou o perito que, por sua vez, aceitou a proposta, parcelando-se as custas. Em momento posterior, "B" requereu a produção de prova pericial, e igualmente, pediu o parcelamento, comprovando sua delicado situação financeira, igualmente. O juizo, contrariamente à confiança emitida pela decisão anterior, contrariamente à boa-fé processual e aos ditames da cooperação, simplesmente negou o pedido de "B", sem nem ouvir o perito ${ }^{674}$, o que caracteriza situação de venire.

Veja-se, por esse exemplo, que ainda que a primeira decisão tenha sido destinada a "A", a confiança foi gerada perante todos os participantes do processo. Isso, em verdade, nada mais é do que reflexo da cooperação sendo concretizada no curso da relação jurídico processual, estimulando-se um diálogo compromissado de todos os integrantes do processo.

\subsection{A adesão à confiança e o lapso temporal}

Além do exercício de situações jurídicas processuais contraditórias e da confiança rompida por meio dessa contradição, é preciso que o sujeito frustrado tenha efetivamente aderido à confiança decorrente do factum proprium. Sem a adesão, não haverá confiança a ser tutelada.

De certa forma, tratamos do tema no item 8.1. supra, quando afirmamos que é preciso que a contradição se dê sobre questões relevantes ao processo, bem como que a ressalva quanto à possibilidade de contradição pode evitar que se forme uma confiança a partir do factum proprium.

Abre-se um item autônomo para tratar da adesão para que seja suficientemente abordada essa peculiaridade do venire processual com relação ao do Direito Civil.

${ }^{674}$ O caso é verídico: TJSP, Agravo de Instrumento n. 2021007-29.2014.8.26.0000, 25ª Câmara de Direito Privado, Des. Rel. Hugo Crepaldi, deram provimento, Julgamento 03/04/2014. 
Inicia-se o estudo, porém, com uma semelhança: da mesma forma que o tema é abordado no Direito Civil, no Processo Civil deve-se entender que, ainda que a adesão à confiança seja uma questão subjetiva (saber se o sujeito de fato confiou em determinado comportamento ou não), sua ocorrência deve ser analisada objetivamente, a partir de dados externos que nos permitam aferir se houve ou não adesão.

No Direito Civil, como afirmamos no item 3.1.3. supra, isso é feito principalmente pela ocorrência do dano: a adesão à confiança evidencia-se com mais razão quando há dano provocado na parte aderente, que, a partir das expectativas geradas pelo factum proprium, agiu de tal forma que, com o comportamento contraditório, verdadeiros danos materiais e morais são observados.

No Processo Civil, a adesão pode se revelar de maneira diversa. Seguindo-se a visão tradicional de que o processo é integrado pelo procedimento, que, por sua vez, é uma sequência de atos concatenados e interligados, ou ainda, considerando-se a visão moderna de cadeia de vículos não necessariamente lineares, o fato é que o procedimento é composto por atos que se influenciam mutuamente - nem sempre um ato influencia todos os demais em sequência, mas certamente um ato encontrará aquele anterior que o influencia.

Conforme é seguida a linearidade dos atos (ainda que limitada à sua respectiva cadeia de vínculos), é de se pressupor que os sujeitos processuais estão confiando nos atos praticados, na capacidade que eles têm de produção de efeitos, dentre os quais, a emissão de expectativas. Assim, a observância da ordem natural da prática dos atos processuais já revela que os sujeitos estão aderindo à confiança emitida por cada conduta.

Não há adesão à confiança quando, por exemplo, tão logo praticado determinado ato processual, a parte adversa ou o órgão julgador manifestam-se no sentido de impugná-lo ou reconhecer sua irregularidade, o que torna esse ato incapaz de se revelar um factum proprium processual. Do contrário, presume-se que os sujeitos processuais, conforme é dada continuidade às cadeias de vínculos, estão aderindo à confiança gerada pelos respectivos atos processuais praticados.

Isso não significa dizer, porém, que o factum proprium e o ato contraditório posterior não possam ser simultaneamente praticados.

Note-se a diferença: quando um ato processual é praticado e desde logo se aponta sua incapacidade de produção de efeitos, ele não chega a se qualificar como factum proprium. Se, contudo, nenhuma irregularidade é apontada, ele passa a integrar uma cadeia 
de vínculos, fazendo com que todos os sujeitos processuais nele confiem, tornando-se pressuposta a adesão à confiança. Entretanto, se o factum proprium é exercido no mesmo contexto temporal da contradição posterior, a confiança não deixa de ser gerada, e a denúncia imediata à contradição se fará já considerando o ato posterior.

A contradição simultânea ao factum proprium, porém, traz uma peculiaridade: ao nos depararmos com dois atos contraditórios praticados em simultaneidade, há uma situação de desconfiança em ambos os atos, de modo que apenas um deles deve prevalecer para que se possa reestabelecer a boa-fé e a cooperação processual. Assim, o reconhecimento do venire servirá para evitar que o procedimento tenha continuidade convivendo com uma situação contraditória afrontadora de expectativas. E, ao afastarmos uma situação de desconfiança, o venire continua cumprindo seu papel de tutelar a confiança processual, reestabelecendo-a.

Nesse sentido, portanto, é que se pode falar em venire na defesa apresentada pelo réu em abuso ao exercício do direito decorrente da regra da eventualidade: a contradição se dá simultaneamente, fazendo-se necessário afastar uma das linhas argumentativas para que o processo siga com a expectativa de boa-fé e cooperação entre os seus participantes.

O lapso temporal, portanto, não se revela como requisito essencial do venire, tratando-se de requisito instrumental à necessária formação da confiança em determinados casos, apenas; o tempo adquire maior relevância em casos de venire por omissão, para que uma mera inatividade não seja interpretada a todo o momento como uma omissão conclusiva.

Em síntese, é possível a ocorrência de venire por condutas simultaneamente praticadas, desde que estejamos tratando de venire comissivo. Em caso de venire por omissão, por sua vez, exige-se lapso temporal como requisito instrumental à existência de confiança geradora de expectativas.

Todavia, uma ressalva deve ainda ser feita: em casos de contradição simultânea do ato decisório do juiz, o sistema já considerou o venire a priori e trouxe a possibilidade de oposição de embargos de declaração (artigo 535, inciso I, do Código de Proceso Civil). Nesse caso, em razão da subsidiariedade do venire, característica que abordaremos no item seguinte, é desnecessário invocar a figura para correção dessa contradição, bastando-se, 
para isso, a oposição dos embargos ou de outro recurso cabível para sanar o equívoco praticado no mesmo ato decisório.

\subsection{Subsidiariedade e aplicação de ofício}

Tal como no Direito Civil, a contradição processual afrontadora de expectativas tem funcionalidade subsidiária ${ }^{675}$.

A premissa para esse raciocínio é entender que o legislador, previamente, tutelou algumas espécies de contradição no ordenamento, vedando-as expressamente. Nesses casos, dispensa-se invocar o raciocínio fundado em princípios, quando já há norma manifesta que exerce a mesma funcionalidade, e que pode ser diretamente invocada.

É o caso, por exemplo, dos casos positivados como sendo atribuídos ao fenômeno da preclusão lógica. Assim, para obstar o conhecimento de um recurso por falta de interesse de agir decorrente de aceitação tácita ou expressa da sentença, basta invocar a norma do art. 503 do CPC. Certamente, o raciocínio à luz da boa-fé objetiva auxiliará interpretar o que é ato de aceitação tácita ou expressa, mas, uma vez firmado esse raciocínio, basta aplicar a consequência do referido artigo.

Da mesma maneira, quando a parte deixa de alegar na primeira oportunidade uma nulidade não cognoscível de ofício, não há necessidade de se falar em venire por omissão, mas apenas aplicar a regra do art. 245 do Código de Processo Civil. O venire, como vimos, terá função essencial em casos de nulidades (relativas ou absolutas) cognoscíveis de ofício e que não estão abarcadas por essa disposição legal, dispensando-o em casos subsumíveis ao artigo 245.

Dessa forma, precisamos da vedação a comportamentos contraditórios, como ferramenta apta a proteger expectativas processuais, nas hipóteses em que a preclusão lógica for insuficiente para atingir essa finalidade, nas hipóteses em que a preclusão para o juiz também o for, bem como em casos em que não houver outras regras processuais expressas capazes de afastar essa contradição.

675 "Las proyecciones que se han explicado de la doctrina son plenamente aplicables en el ámbito del procedimiento civil, de modo tal que, la misma subsidiariedade atribuida se recpta en su utilidad procesal" (OSVALDO GoZAínI, La conducta en el proceso, p. 206). 
E, uma vez identificado pelo magistrado caso em que houve afronta de expectativas processuais, a vedação de comportamentos contraditórios pode ser feita de ofício.

Lembremos que o juiz é remetente, mas também destinatário de expectativas processuais e, como tal, a fim de preservar a finalidade pública do processo, em prol da concretização dos princípios da boa-fé objetiva e da cooperação, pode atuar de ofício vedando condutas contraditórias ${ }^{676}$.

É certo que, em muitos casos, como por exemplo, nas hipóteses em que a contradição se dá a partir de comportamentos praticados fora da mesma sede processual, o reconhecimento do venire dependerá de informação trazida pelas partes. Providenciandose o seu conhecimento quanto à contradição, por sua vez, a vedação de condutas contraditórias pode e deve ser feita de ofício ${ }^{677}$.

\subsection{Consequências da vedação de comportamentos processuais contraditórios}

Conforme noticiado anteriormente, a prática de condutas contraditórias afrontadoras de expectativas, no Processo Civil, implica consequências diversas se comparadas com as do Direito Civil, principalmente quando se trata de contradição dos sujeitos parciais.

No Direito Civil, por não haver interesse público necessariamente em jogo, bem como considerando a finalidade instrumental que só qualifica o Processo, a tutela da confiança é a tutela dos interesses de uma contraparte privada, apenas, de modo que as

\footnotetext{
676 "En síntesis: somos de la opinión de que los jueces pueden y deben invocar oficiosamente - y sin retaceo alguno - la doctrina de los 'propios actos', ora respecto de la relación subsancial, ora a respecto de la relación procesal" (JoRge PeYRANo, La doctrina de los propios actos en el ámbito del procedimiento civil, p. 241). "La inadmisibilidad del 'venire contra factum proprium', en el sentido que la ha ido dando nuestra jurisprudencia, tiene ante todo el carácter de una norma jurídica. Una norma jurídica puede fundamentar una excepción, pero puede - o, mejor dicho, debe - ser aplicada espontáneamente por el tribunal, aun cuando no haya sido alegada por las partes. Planteado un determinado litigio, el tribunal puede apoyar la desistimulación de la demanda, en el principio de que a nadie le es lícito ir contra sus propios actos, aun cuando esta regla no haya sido alegada por las partes" (DIEZ PICAZO, La doctrina de los propios actos, $\mathrm{p}$. 169).

677 "Si bien la contraposición es elocuente y surge sin hesitación de la simple lectura de los actos de postulación y defensa, el Juez podrá advertir el origen de la 'conducta anterior', de modo tal que, tanto por el principio iura novit curia como por la función integrativa para la composición del proceso, estaría en condiciones de hechar mano de la doctrina señalada" (Osvaldo GozAínI, La conducta en el proceso, $\mathrm{p}$. 220).
} 
consequências limitam-se a buscar reequilibrar essa situação de confiança, ressarcindo eventuais danos provocados.

No Processo, porém, considerando sua finalidade essencialmente pública, não se olvidando de seus escopos instrumentais à realização da função jurisdicional, acresce-se ao reequilíbrio da confiança um caráter valorativo da conduta contraditória praticada pelas partes, o que auxilia na formação da convicção do magistrado, bem como um caráter sancionador, porquanto, além de se romper com a confiança de uma contraparte, a conduta processual contraditória fere os interesses do Estado, da administração da justiça, merecendo, por isso, a aplicação de sanção ${ }^{678}$.

Note-se, portanto, que, quando há venire do juiz a consequência é uma só: buscar a situação de reequilíbrio da confiança do jurisidicionado no órgão julgador. Quando o venire é praticado pelas partes, além do reestabelecimento de confiança, há a possibilidade de valoração da conduta (o que certamente não se aplica ao órgão julgador, já que sua conduta não pode servir de indício), e ainda, aplicação de sanção por litigância de má-fé (que tem por destinatário apenas os sujeitos parciais, afinal, o juiz sequer litiga, seus interesses particulares não estão envolvidos no processo).

E vale a pena frisar que as consequências a seguir elencadas podem incidir cumulativamente em um mesmo caso, porquanto assumem destinações distintas (vedar efeito do comportamento contraditório, desestimular esse tipo de conduta e formar convicção do magistrado). Todavia, nem sempre se farão presentes, pois, como veremos adiante, a limitação à aplicabilidade do venire processual pode significar, na prática, a aplicação de apenas uma dessas consequências, em detrimento das demais.

\subsubsection{Reequilíbrio da confiança: a não produção de efeitos do comportamento contraditório}

A consequência lógica para que seja possível reestabelecer a confiança gerada pelo factum proprium, e que, portanto, aplica-se a todos os sujeitos processuais em

\footnotetext{
${ }^{678}$ Não à toa que MARIO MASCIOTRA afirma: "La conducta con significación procesal exteriorizada por las partes en el desarollo del proceso puede ser apreciado en un doble aspecto, uno sancionatorio y otro probatorio."'(La conduta procesal de las partes, p. 123).
} 
contradição, é obstar a produção de efeitos do comportamento processual contraditório. O problema é que isso pode ser feito de diversas formas no processo, sem possibilidade de tipificação a priori.

Nesse ponto, vale pensar que o venire posiciona-se como ferramenta destinada a proteger a boa-fé objetiva e a cooperação processual. Aquela é cláusula aberta no sistema processual, prevista no art. 14, inciso II, do atual CPC; esta é princípio que também se concretizará pela técnica legislativa de cláusula geral no projeto de Código de Processo Civil, implementando uma forma de divisão do trabalho que, por sua vez, concretiza uma série de princípios constitucionais.

Uma cláusula aberta é caracterizada, como vimos, por ter o suporte fático e a consequência jurídica não definidos previamente pelo legislador. O suporte fático, no nosso estudo, será definido pela adoção de comportamentos contraditórios que firam esses princípios. As consequências jurídicas, por sua vez, serão indeterminadas, correspondendo a tantas quantas forem aquelas necessárias a fazer valer esses princípios, reestabelecendose a confiança.

Não é o caso de nos aprofundarmos sobre o quanto a técnica da cláusula geral é benéfica e/ou apresenta perigos ao ordenamento na medida em que amplia demais o espaço interpretativo do órgão julgador. Além de já termos sinalizado nosso posicionamento em capítulos anteriores, o fato é que a cláusula geral da boa-fé objetiva é uma realidade em nosso sistema, e continuará sendo se aprovado o projeto do Novo Código Civil, o que nos leva a buscar utilizá-la da melhor maneira possível.

A atipicidade das consequências possíveis em prol do reestabelecimento da confiança é mitigada pela atividade jurisprudencial, pelo preenchimento das lacunas deixadas propositadamente pelo legislador, ciente de sua incapacidade de previamente regular todas as situações da vida relevantes ao ordenamento.

O nosso estudo no Capitulo 2 revela, justamente, que a jurisprudência se comporta de modo a aplicar a consequência necessária conforme requeira o caso concreto a fim de se atingir a equalização de expectativas: ora se considera sem interesse de agir determinada conduta, ora desconsidera-se uma alegação contraditória a outra anteriormente formulada, ora julga-se o mérito da ação, porque ele é em si verdadeira contradição a condutas anteriores. Essa, portanto, é a regra: a adoção de comportamentos 
contraditórios implica tornar sem efeito a conduta contraditória, o que se traduz em resultados práticos diversos.

Mas para que todos esses efeitos práticos se observem, há sempre a mesma premissa: o comportamento contraditório não pode ser praticado, ou seja, a confiança gerada pelo factum proprium impede que seja exercida determinada situação jurídica processual em contradição e, caso ela tenha sido exercida, seus efeitos devem ser afastados.

A semelhança com o que se observa pela preclusão não é mera coincidência: como já afirmado anteriormente, a preclusão é uma das consequências do venire processual, mas, dadas as limitações do instituto, bem como sua utilização para vedar condutas que em nada correspondam à contradição de condutas (como a preclusão temporal), preferimos chamar esse fenômeno de simples "vedação": é a vedação tal como exercida pela preclusão, porém sempre ligada a condutas contraditórias, e jamais limitada a barreiras endoprocessuais, podendo, ainda, incidir mediante confiança gerada por conduta omissiva.

Assim, retomamos afirmação já feita anteriormente: é uma das consequências da conduta processual contraditória a impossibilidade de a situação jurídica exercida em contradição produzir efeitos, o que poderia plenamente ser chamado de preclusão, não fosse o receio de a "vedação" ficar limitada às barreiras da funcionalidade da preclusão.

E note-se que, não obstante termos ressaltado a diferença da consequência do vício de forma com relação às partes (que é de inadmissibilidade) quando comparada com o vício da atividade judicial (invalidade, com possível nulidade), aqui unificamos todas as consequências para o plano da ineficácia, apenas.

E isso não se mostra atécnico quando pensamos que, via de regra, todos os atos inválidos, por não preencherem os pressupostos de validade, não se tornam eficazes, não chegam a reunir os requisitos necessários a atingir o plano da eficácia. Assim, via de regra, tanto atos ineficazes quanto atos inválidos são incapazes de produzirem efeitos.

A grande diferença que nos faria separar os atos inválidos do juiz dos atos ineficazes das partes seria a possibilidade de convalidação daqueles. Todavia, como o intuito é justamente obstar a prática de um segundo ato contraditório, não há que se falar em convalidação, corrigindo-se o vício apenas pela exclusão do ato do mundo jurídico. 
Dessa forma, uma vez vedada a conduta em contradição, os efeitos práticos processuais poderão ser diversos, como de fato o são pelo que se observou da análise jurisprudencial do Capítulo 2 supra.

Há apenas uma peculiaridade quando configurado o caso de contradição simultânea. Nessa hipótese, qual o ato a ser vedado?

A simultaneidade de atos contraditórios ocorrerá sempre considerando, em verdade, cada alegação da parte como um ato distinto, dentro de um mesmo ato processual $^{679}$, como apresentação de contestação ou de outra peça processual. O juiz, então, terá que afastar a eficácia de uma linha argumentativa, a fim de reestabelecer a confiança processual.

E será ineficaz a tese mais favorável ao sujeito em contradição, à luz da valoração desse comportamento contraditório. A valoração como consequência possível do venire será abordada a seguir, mas desde logo se revela importante na medida em que, em casos de contradição simultânea, será ela a forma de identificar a conduta a ser vedada: o comportamento em contradição serve de indício a partir do qual se cria a presunção fundada na regra de experiência de que, frente a teses contraditórias, será mais verídica aquela menos favorável ao sujeito em contradição - de que a verdadeira é a menos favorável, tornando ineficaz aquela mais favorável.

Assim, no caso de apresentação de defesa direta e indireta incompatíves, a defesa direta, mais favorável porquanto incumbe ao autor a comprovação de suas alegações, torna-se ineficaz, incapaz de produzir seu efeito típico de controverter esses fatos simplesmente negados, mantendo-se a tese defensiva apresentada como defesa indireta, a qual incumbe ao réu comprovar. Da mesma maneira, em casos de defesas indiretas incompatíveis, o juiz poderá deixar de inserir como objeto de prova desde logo aquela mais favorável, atribuindo ao réu o ônus de provar a versão que menos lhe favorece.

\subsubsection{Sanção pecuniária}

\footnotetext{
${ }^{679}$ Pode parecer estranho, mas, de fato, consideramos cada alegação processual em sua individualidade, como ato processual distinto, porquanto cada qual é capaz de produzir efeitos processuais distintos. Basta pensar que, na peça contestatória, há a imposição do ônus de impugnação específica, o que indica que o sistema processual dá relevância autônoma a cada alegação formulada.
} 
No que se refere ao venire das partes, a contradição afrontadora da boa-fé processual rompe não só as expectativas da parte adversária de que o processo se pautaria na lealdade e na confiança, mas também do órgão jurisdicional. Tal conduta é indesejada aos interesses públicos do processo, e, a fim de se mantenham as expectativas da cooperação, deve ser desestimulada. Daí a possibilidade de incidência de sanções pecuniárias.

Como vimos, o venire processual é uma modalidade de abuso do processo. E, para nós, a litigância de má-fé nada mais é do que um conjunto de casos positivados de abuso, ambos prescindindo da análise do elemento subjetivo. Dessa maneira, é possível aplicar as sanções de litigância (multa e indenização) para os demais casos de abuso, tal como a hipótese de venire processual das partes.

A multa a incidir está limitada, na atual legislação, a 1\% do valor da causa (artigo 18 do Código de Processo Civil). Caso aprovada a atual redação do projeto de Novo Código de Processo Civil, a multa poderá ser fixada entre 1 e $10 \%$ do valor da causa, e se este for irrisório, em até dez vezes o salário mínimo (art. 81 , caput e $\left.\$ 3^{\circ}\right)^{680}$.

Com relação à indenização, seu cabimento parece ser aceito para majoritária doutrina a despeito da prova de dano efetivo, pois, considera-se que a conduta do litigante de má-fé traz dano intrínseco aos demais sujeitos processuais. Porém, como já ressaltamos oportunamente (item 6.2 supra), esse não é o entendimento da jurisprudência do Superior Tribunal de Justiça, que requer a demonstração do dano para que seja concedida indenização.

A orientação do Superior Tribunal de Justiça parece ser a mais adequada. Considerando que a multa é destinada à contraparte e não ao Estado, é possível dizer que ela cumpre a dupla funcionalidade de desestimular condutas contrárias ao escopo do processo (função sancionadora), bem como de ressarcir os danos ordinários decorrentes da conduta, ou seja, esses danos intrínsecos à litigância de má-fé, ainda que assim seja considerada a prorrogação do dano marginal do processo (função ressarcitória). Para que seja aplicada indenização, portanto, parece-nos mais adequada a necessária demonstração efetiva de danos que extrapolem os limites daqueles que ordinariamente são observados.

A doutrina pode ser estimulada a apoiar a solução de conferir intrínseca indenização pelo fato de que, no atual sistema, o limite da multa a $1 \%$ do valor da causa

${ }^{680}$ Versão disponível em < http://www.migalhas.com.br/arquivos/2014/3/art20140326-01.pdf>. 
mostra-se bastante irrisória a ressarcir os danos decorrentes da litigância. Todavia, a redação do Novo Código de Processo Civil corrigiu essa distorção, estendendo a possibilidade de imposição de multa para até $10 \%$ do valor da causa, ou até 10 vezes o salário mínimo.

Com mais razão, portanto, o entendimento do Superior Tribunal de Justiça após a inserção da nova sistemática como realidade legislativa.

Em resumo, a multa será devida em caso de adoção de comportamento processual contraditório; a indenização, por sua vez, demanda efetiva comprovação de danos outros que não aqueles intrinsecamente ligados à conduta do litigante de má-fé (chamados de danos morais ou agravamento dos danos marginais).

\subsubsection{Valoração da conduta contraditória: a presunção desfavorável}

Muito já foi dito com relação à valoração da conduta judicial. Vimos que nem sempre a valoração se dá a partir de comportamentos contraditórios, concluindo, naquela oportunidade, que a figura que mais se assemelha ao nosso objeto de estudo é a autocontradición ou intercadencia, porquanto sempre fundada em condutas contraditórias, bem como passível de ser configurada a partir de condutas praticadas fora de uma mesma sede processual.

Vimos, porém, que ainda assim não são figuras coincidentes, pois (i) a intercadencia tem finalidade apenas probatória, (ii) ela independe de análise da quebra da boa-fé processual objetiva, (iii) ela só gera um efeito (adotar a versão menos favorável) e (iv) ela não possui qualquer relação com os comportamentos do órgão julgador.

A doutrina brasileira, todavia, pouco faz referência à valoração da conduta, e não é familiarizada com a diferenciação desta para a autocontradición. Não há motivos, portanto, para que trabalhemos com essa diferenciação, sendo possível inserir as hipóteses chamadas de autocontradición dentro do gênero valoração de condutas, permitindo que, por meio da valoração, sejam consideradas condutas praticadas fora da mesma sede processual.

Dessa forma, quando forem praticadas condutas contraditórias, dentro ou fora de uma mesma sede processual, que afrontem a boa-fé objetiva, e que sirvam à valoração 
judicial de modo a influenciarem no julgamento da demanda, é possível que a valoração da conduta se posicione como consequência do venire processual das partes - lembrando que o instituto não se aplica ao órgão julgador.

Já foi citado o exemplo em que isso ocorre quando da apresentação de defesa incompatível, permitindo-se que o juiz valore a conduta contraditória, tornando ineficaz ao seu convencimento a apresentação daquela mais favorável ao sujeito em contradição.

O mesmo pode ocorrer - e ocorre com frequência, muitas vezes sem que o julgador anuncie que está valorando a conduta da parte, simplesmente fazendo-o - quando há conduta contraditória praticada fora da sede processual, como, por exemplo, uma confissão, uma declaração em um boletim de ocorrência, uma afirmação feita em outro processo, tudo de forma a contradizer alegações feitas pelas partes no processo. Nesses casos, o juízo pode presumir verdadeira a versão que menos favorece o agente da contradição, competindo a ele fazer prova em sentindo contrário.

Principalmente em caso de ausência de acervo probatório, o mecanismo da valoração da conduta processual acaba sendo grande auxiliador para formação da convicção do juiz, permitindo-o criar presunções a partir de condutas contraditórias, e, assim, distribuir de maneira diversa o ônus da prova ${ }^{681}$.

\subsection{Limitações quanto à aplicabilidade}

Ao longo do trabalho, fomos elencando situações em que o venire processual deixa de ser aplicado, o que deve ser ressaltado para que a sistematização se dê de maneira mais clara.

Em primeiro lugar, quando (i) falta liberdade às condutas praticadas pelo agente em contradição, não é possível se falar em venire processual. Vimos que é requisito de uma conduta vinculativa, em termos de expectativas, a existência de "espaço de manobra", de modo que condutas praticadas porque impostas pelo ordenamento ou pelo órgão judicial são incapazes de gerarem confiança ${ }^{682}$.

\footnotetext{
${ }^{681}$ Sobre a relação entre presunções relativas e inversões do ônus da prova, $c f$. CÂNDIDO RANGEL DinAMARCo, Instituições de Direito Processual Civil, v. III, pp. 76-77.

${ }^{682}$ Semelhante raciocínio é desenvolvido por ENRIQUe VALLINES GaRCía quanto às exceções de aplicabilidade de preclusão, $c f$. La preclusión en el proceso civil, pp. 335 e seguintes.
} 
Nesse ponto, é possível relacionar à falta de liberdade a existência de vícios de vontade quando da prática das condutas contraditórias processuais.

No campo do Direito Civil - em que a importância do tema dos vícios de vontade é incontroversa -, muito se discute quanto à consequência produzida pela existência de um vício de vontade na teoria da vedação de comportamentos contraditórios. O ponto de divergência é o seguinte: uma vez praticado um ato, que gerou expectativas em terceiros, se posteriormente venha a se descobrir que ele estava viciado - por erro, coação, dolo, ou algum dos demais vícios de vontade do negócio jurídico -, o que prevalece, a proteção à confiança ou a necessária anulação do ato?

Parte da doutrina civilista entende que o factum proprium somente pode ser assim considerado se representar uma livre manifestação de vontade, sem vícios. Afinal, se viciado, as expectativas dele emanadas não são dignas de proteção ${ }^{683}$. De outro lado posicionam-se aqueles que privilegiam a confiança gerada, ou seja, protegem o terceiro que, sem saber do vício existente, confiou na validade da primeira conduta ${ }^{684}$.

No campo do Direito Processual Civil, já não é tão simples a aceitação da relevância dos vícios da vontade como forma de influenciar os atos processuais. A doutrina tradicional é majoritariamente contrária a essa influência, principalmente por afirmar que a vontade do agente é irrelevante para determinar a produção de efeitos dos atos processuais, que já estão previamente descritos em lei ${ }^{685}$.

Mas essa premissa já foi desconstruída pela doutrina moderna, notadamente por PAULA DA COSTA E SiLVA com relação ao ato postulativo ${ }^{686}$, que bem descreve que a vontade para a prática do ato é relevante, ainda que ela não seja relavante para a produção

\footnotetext{
683 "La voluntad plasmada en el primer acto, que luego se pretende contradecir, debe haber sido libre, pues si hubiera sido coaccionada de algún modo, no se aplicaría a este caso la doctrina del 'venire contra factum"” (Marcelo Mesa e CARlos Vide, la doctrina de los actos propios, p. 118). No mesmo sentido, JoRGE PEYRANO, La doctrina de los propios actos en el ámbito del procedimiento civil, pp. 231-232, PAULO MOTA PINTO, Sobre a proibição do comportamento contraditório no direito civil, p. 165;

684 Osvaldo GozAÍNI, La conducta en el proceso, pp. 192-193; ANA I. PIAGGI, Reflexiones sobre dos princípios basilares del derecho: La buena fe y los actos próprios, p. 112; ALEJANDRO BORDA, La teoria de los actos propios, p. 71; DíEZ-PICAZO, La doctrina de los propios actos, pp. 209-212, ressaltando esse último autor que o erro passa a ser excludente da incidência do venire caso a parte confiante tenha ciência da existência dele, o que impede que haja legítima confiança formada e a a ser protegida.

${ }^{685}$ CÂNDIDO RANGel DinAmarCo, Instituições de Direito Processual Civil, v. II, p. 484.

686 "O acto postulativo é o acto através do qual a parte formula um pedido ao tribunal. Tanto é acto postulativo aquele através do qual a parte requer ao tribunal que conheça uma questão de fundo, como é acto postulativo aquele em que a parte formula o pedido de conhecimento de um questão meramente processual." (Paula Costa e Silva, Acto e processo, p. 211).
} 
de efeitos daquele ato; afinal, tornando inexistente o ato em si, o vício de vontade acaba por afastar qualquer produção de efeitos ${ }^{687}$.

Dessa forma, partindo da premissa de que há relevância dos vícios de vontade na prática de atos processuais postulativos, encontramo-nos no mesmo ponto da doutrina civilista, no embate entre a proteção da confiança de terceiros e a proteção da livre manifestação da vontade ${ }^{688}$.

E entendemos existir aqui uma limitação à aplicação da teoria da vedação de comportamentos contraditórios, quando o vício representar a ausência de liberdade na prática do ato, ou seja, quando a escolha por praticar determinado não for livre ${ }^{689}$.

Assim, se houver factum proprium viciado, o ato contraditório posterior será inclusive quisto pelo sistema processual, para que seja alertado e sanado o vício anterior. Nesse caso, a proteção do terceiro não deve se dar com o venire, mas apenas em caráter indenizatório, eventualmente. Essa nos parece ser a melhor maneira de equalizar os interesses em jogo, protegendo a livre manifestação de vontade e, paralelamente, compensando eventuais danos a terceiros por outros mecanismos, como a responsabilidade civil, se preenchidos seus requisitos.

E, também ligadas à falta de liberdade estão as situações em que o direito material blinda de consequências jurídicas a atuação volitiva das partes.

Há situações jurídicas que o direito material disciplina de modo a excluir qualquer possibilidade de modulação de efeitos a partir da conduta das partes, casos, portanto, em que a conduta é abstratamente afastada como apta a produzir consequências jurídicas. Nessas hipóteses, há limitação a uma das consequências do venire, qual seja, a de

\footnotetext{
${ }^{687}$ Nas palavras da autora "Da circunstância de a lei intervir na fixação dos efeitos do acto não decorre que o sistema desconsidere o modo como o acto, ao qual aderirão efeitos heteronomamente, adquiriu existência." (Acto e processo, p. 468).

${ }^{688}$ E isso porque, como afirma PAUla COSTA E SiLVA, "O legislador sabe que, ao admitir a destriuição de um acto de auto-regulamentação e de autovinculação, está a admitir uma quebra ao princípio de que a vinculação se deve manter, pondo, consequentemente, em causa, tanto a confiança e os interesses de quem agiu na pressuposição de que o acto é válido, como, em última instância, os interesses do tráfego jurídico" (Acto e processo, p. 489). Ou seja, o reconhecimento de um vício de consentimento tem por inevitável consequência a quebra da confiança de quem confiou no ato.

${ }^{689}$ Referimo-nos aqui, portanto, não a todos os vícios de vontade, mas principalmente à coação, seja ela física ou moral - esta última tem um agir com vontade, mas vontade viciada pelo medo da outra consequência prometida pelo coator. O erro, por sua vez, fica fora até mesmo da categoria de vícios relevantes aos atos processuais postulativos, pois, se assim fosse admitido, não haveria mais decisões de improcedência, bastaria a alegação da escusa na incidência em erro na interpretação dos fatos e categorias jurídicas, como bem conclui PAUla Costa E Silva, Acto e processo, pp. 559 e seguintes.
} 
tornar ineficaz o comportamento contraditório. Afinal, sendo o comportamento irrelevante, predominará sempre os efeitos disciplinados pela lei material.

Exemplifica-se, para melhor aclarar o assunto.

Ao disciplinar as regras de indisponibilidade de um bem, o direito material tem por escopo blindar a transmissibilidade dele, a despeito de a conduta das partes assim pretender fazê-lo. Nesse contexto, caso a parte afirme em uma demanda judicial a disponibilidade do bem, a conduta contraditória afirmativa da indisponibilidade não poderá perder eficácia em razão da limitação de direito material existente. Note-se: estará configurado o venire processual, mas vedada a incidência de apenas uma de suas consequências, sem impedimentos, porém, para que sejam aplicadas sanções pecuniárias ou valorações desse tipo de comportamento.

O mesmo vale para a disciplina da atuação dos incapazes pelo Direito Civil. Quando a tutela da expectativa processual representar violação de norma de direito material que blinda de consequências a conduta do incapaz, prevalecerá o direito material, de modo que o venire processual produzirá como consequências em potencial apenas sanções pecuniárias e valoração de condutas.

Em segundo lugar, há ausência de confiança a ser rompida quando (ii) há ressalva motivada de possibilidade de posterior contradição. As ressalvas do juiz e das partes no sentido de que pode advir conduta posterior contraditória vão construindo as exatas expectativas nos demais sujeitos, impedindo que se forme a confiança, de modo que a posterior contradição possa ser admitida com mais facilidade. É o que ANTONIO DO PASSO CABRAL bem chamou de "previsibilidade da mudança de comportamento": não se forma confiança legítima quando há previsibilidade da possível alteração comportamental, ao passo que, ausente essa previsibilidade, muito maiores as chances de haver confiança a ser tutelada ${ }^{690}$.

Em terceiro lugar, há situações em que (iii) a contradição, sem exceção (diferentemente do que se estabeleceu em relação à regra da eventualidade), é permitida: são os casos em que a lei expressamente prevê a possibilidade de retratação, casos

\footnotetext{
${ }^{690}$ Nas palavras do autor: "Já a legitimidade da confiança é baseada, em grande medida, na imprevisibilidade da mudança de comportamento. Se o comportamento foi declarado como contrariável no futuro, pelo agente ou pela lei, não há confiança legítima. No processo, isso é fundamental porque, enquanto o sujeito deixar expressamente aberta a possibilidade de reavaliação do comportamento no curso da cadeia, mantém-se a sua imprevisibilidade. Quando isso ocorre, não se configura qualquer padrão de conduta estável e não há que se invocar boa-fé, porque não já segurança jurídica ou confiança legítima a ser tutelada" (Nulidades no processo moderno, p. 325).
} 
elencados anteriormente como sendo espaço em que não incide a preclusão para o juiz e, igualmente, não cabe se falar em venire, uma vez a lei deixou evidente que, nesse espaço, poderá o juiz decidir em absoluta contrariedade com sua decisão anterior, uma vez interposto o recurso. O venire poderá auxiliar, nesses casos, apenas quando houver lapso temporal muito grande entre a decisão recorrida e a pretensa retratação, pois, nessa hipótese, uma omissão duradoura pode ser conclusiva no sentido de que o órgão julgador não mais se utilizaria do poder-dever de se retratar.

Por fim, temos que ter em mente - e nunca perder isso de vista - que o venire é uma ferramenta processual destinada a concretizar os valores da boa-fé e da cooperação. Há casos, porém, em que esses (iv) valores colidirão com outros igualmente relevantes ao sistema processual, e, nessa colisão, é possível que a boa-fé e a cooperação sejam enfraquecidas, o que corresponderá à mitigação das consequências do venire processual.

Vislumbramos essa possibilidade na hipótese de a segunda conduta, aquela contraditória e que deveria ter seus efeitos vedados, mostrar-se mais próxima da veracidade do que a primeira, caso em que não será a confiança a prevalecer, e sim a veracidade: isso implicará afastar a consequência da vedação e da valoração da conduta contraditória, aplicando-se, no limite, apenas a sanção pecuniária.

Ainda que a busca da verdade como valor autônomo no processo civil seja alvo de polêmicas, é inegável que somente com a reconstrução dos fatos com a maior fidelidade possível ao que ocorreu no mundo naturalístico será possível se atingir os escopos do processo, será possível se atingir a decisão justa ${ }^{691}$. Ademais, ainda que não elejamos a verdade como o valor a colidir com a boa-fé e a cooperação, a colisão se dará com o princípio do livre convencimento motivado.

Nesse conflito, e na busca de mitigar o menos possível cada um dos valores envolvidos, a sugestão que se dá é que prevaleçam os efeitos da conduta que se mostre mais verossímil diante da realidade dos fatos, porém sem deixar de desestimular a afronta à boa-fé, aplicando-se a sanção pecuniária. Assim, ainda que haja mitigação da boa-fé, ela não deixa de ser protegida.

${ }^{691}$ Ver, por todos, MichelE TARUFFO, Uma simples verdade: o juiz e a construção dos fatos. 


\subsection{Principal contribuição: incentivo ao diálogo pelo necessário alinhamento de expectativas no curso de toda relação jurídica processual}

Esse item poderia estar inserido dentro das consequências da adoção de condutas processuais contraditórias, mas, como se trata de um efeito indireto, um efeito reflexo da aplicação do venire, bem como por ser a mais fundamental consequência, optamos por lhe conferir maior destaque, já caminhando para a conclusão.

A atual concepção de Direito envolve não apenas a admissão de que ele seja permeado por valores, mas também que sirva como ferramenta implementadora desses valores eleitos como essenciais pela sociedade, deixando de se comportar como uma superestrutura passiva para agir ativamente na indução de comportamentos condizentes com os valores por ele tutelados ${ }^{692}$. O Direito, portanto, requer mecanismos aptos a implementar esses valores, e é nesse contexto que se insere a vedação de comportamentos processuais contraditórios.

Mais do que uma ferramenta repressiva de comportamentos contraditórios, busca-se por meio da figura que haja incentivo a condutas que observem a boa-fé e a cooperação processual, de modo que os sujeitos processuais analisem previamente suas condutas, evitando contradições que rompam expectativas no processo.

O incentivo maior, a nosso ver, será no fomento ao diálogo: preocupados em não se contradizer, os sujeitos serão estimulados a dialogar, a expor suas intenções e a ressalvar hipóteses de possível contradição, concretizando a ideia de comunidade de trabalho desejada pelo modelo cooperativo.

Em síntese, mais do que vedar condutas, o que se espera como contribuição deste trabalho é que o venire jamais seja invocado, aplicando-o apenas no plano das ideias dos sujeitos processuais, para que eles, antes de se contradizerem, sejam capazes de evitar a prática desse comportamento indesejável no processo moderno.

\footnotetext{
${ }^{692}$ Sobre a função promocional do ordenamento jurídico, merece destaque a obra de NORBERTO BOBBIO, $D a$ estrutura à função, p. 1-32. Nesse livro o autor apresenta uma nova concepção de Estado contemporâneo: "Em poucas palavras, é possível distinguir, de modo útil, um ordenamento protetivo-repressivo de um promocional com a afirmação de que, ao primeiro, interessam, sobretudo, os comportamentos socialmente não desejados, sendo seu fim precípuo impedir o máximo possível a sua prática; ao segundo, interessam, principalmente, os comportamentos socialmente desejáveis, sendo seu fim levar a realização destes até mesmo aos recalcitrantes" (Da estrutura à função, 15).
} 
Essa função preventiva do venire processual ganha ainda maior relevância conforme seja atribuída mais liberdade aos sujeitos processuais.

Com efeito, ideias como a de flexibilização do procedimento ${ }^{693}$ ou de

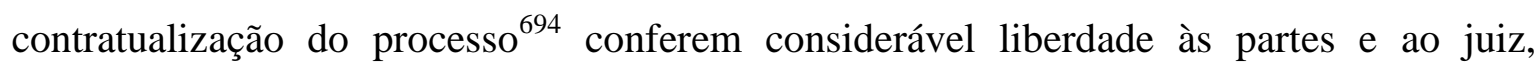
ampliando-se os seus espaços de manobra. Quanto maior a liberdade, mais chance há dos sujeitos contradizerem-se, de buscarem voltar atrás quando o caminho escolhido não lhes trouxer resultado favorável. Nesse contexto, ganha importância o venire processual, como mecanismo preventivo e repressivo em prol da tutela da confiança processual, permitindo que a liberdade seja bem utilizada e garantindo que, em caso de má utilização, os efeitos indesejáveis ao processo possam ser obstados.

\footnotetext{
${ }^{693}$ Tendência inserida no art. 191 do projeto de novo CPC (projeto de lei n. 6.025/2005): "Versando a causa sobre direitos que admitam autocomposição, é lícito às partes plenamente capazes estipular mudanças no procedimento para ajustá-lo às especificidades da causa e convencionar sobre os seus ônus, poderes, facultadas e deveres processuais, antes ou durante o processo".

${ }^{694}$ Tendência inserida no art. $191, \S \S 1^{\circ}$ a $3^{\circ}$ do projeto de novo CPC (projeto lei n. 6.025/2005), por meio da previsão do calendário processual: " $\$ 1^{\circ} \mathrm{De}$ comum acordo, o juiz e as partes podem fixar calendário para a prática dos atos processuais, quando for o caso. $\$ 2^{\circ} \mathrm{O}$ calendário vincula as partes e o juiz, e os prazos nele previstos somente serão modificados em casos excepcionais, devidamente justificados. $\S 3^{\circ}$ Dispensa-se a intimação das partes para a prática de ato processual ou a realização de audiência cujas datas tiverem sido designadas no calendário".
} 


\section{CONCLUSÃO}

O trabalho se iniciou com a demonstração da importância prática do tema. Constatou-se que a teoria de vedação de comportamentos processuais contraditórios é uma realidade na jurisprudência brasileira, realidade tão ou mais expressiva do que aquela observada na utilização do nemo postet venire contra factum proprium em um contexto puramente negocial, típico do Direito Civil. Isso surpreendeu na medida em que a vedação de comportamentos contraditórios é, em sua origem, uma figura pertencente ao campo do direito privado.

Todavia, a segurança da imprescindibilidade do estudo do venire processual evidenciada a partir do estudo da jurisprudência foi seguida pelo incômodo de se buscar resolver os inúmeros questionamentos trazidos pela aplicabilidade prática do instituto. Afinal, como compreender a incidência do venire na seara processual? Quais suas bases jurídicas, suas funções e restrições?

Para responder a esses e outros questionamentos feitos logo nos dois primeiros capítulos, mostrou-se necessário conhecer a teoria em seu sentido tradicional, tal como estudada pelos civilistas, aproveitando-nos de suas principais conquistas.

No Direito Civil, vimos que a teoria de vedação a comportamentos contraditórios tem por pressupostos: (i) o factum proprium; (ii) a confiança gerada por esse factum; (iii) um segundo comportamento contraditório em relação ao primeiro e (iv) um dano efetivo ou em potencial.

Nesse ponto, é importante ressaltar nossas conclusões no sentido de que o factum proprium pode ser tanto um comportamento comissivo quanto omissivo - de modo que inserimos na categoria do nemo postest venire contra factum proprim a suppressio -, bem como que toda a tutela da vedação da contradição só tem razão de ser porque, na verdade, o que se busca é a tutela da confiança, das legítimas expectativas decorrentes da conduta inicial vinculante.

E, como bases jurídicas para se tutelar a confiança por meio da vedação de comportamentos contraditórios, os civilistas apontam (i) a boa-fé objetiva, (ii) o abuso do direito e (iii) a solidariedade social. 
A boa-fé objetiva é, em nosso ordenamento atual, um princípio jurídico e uma cláusula geral, ou seja, um valor fundante e uma técnica legislativa. Difere-se da boa-fé subjetiva por ser esta a crença do sujeito de estar atuando em conformidade com o ordenamento. Aquela, por sua vez, é o padrão social de conduta ligado à honestidade e à lealdade esperada de todo homem médio. A teoria da vedação de comportamentos processuais contraditórios relaciona-se com a boa-fé objetiva, já que veda a contradição que rompe uma confiança gerada segundo os padrões de conduta de uma sociedade.

Dentre as funções da boa-fé objetiva, interpretativa, supletiva ou limitativa, destaca-se esta última, que, por sua vez, relaciona-se com o abuso de direito. O abuso de direito é um mecanismo de limitação de situações jurídicas subjetivas, sempre que o exercício delas, com aparência de legalidade, acaba por se desviar da finalidade original. $\mathrm{E}$ a boa-fé objetiva é um dos critérios por meio do qual se identifica o desvio de finalidade, motivo pelo qual o venire se posiciona como um abuso de direito (por ser uma ferramenta limitadora de situações jurídicas subjetivas) pela afronta à boa-fé.

Ademais, aponta-se o princípio da solidariedade social como fundamento constitucional para a vedação de comportamentos contraditórios na medida em que proteger a confiança é preocupar-se com o próximo, com o convívio em sociedade.

E são consequências do nemo postest venire contra factum proprium identificadas pelo Direito Civil a função impeditiva de tornar sem efeito o comportamento contraditório, bem como a função reparatória, para compensar os danos decorridos da quebra de expectativas.

Iniciado o nosso estudo no campo do Direito Processual, foram analisadas as situações jurídicas processuais, por representarem o modo de agir dos sujeitos processuais, ou seja, o modo pelo qual podem ser exercidas condutas contraditórias no processo.

E, sobre essa análise, vale destacar que, no que concerne às partes, somente o exercício de poderes, faculdades e ônus é permeado por alguma liberdade; no que se refere ao juiz, a liberdade está na interpretação decisória. A identificação da presença de alguma liberdade é fundamental porque a ausência dela implica impossibilidade de configuração do venire, como retomaremos adiante.

Vimos, ainda, que a omissão é uma situação jurídica relevante, e não só a omissão de condutas passivas, mas também a de condutas ativas, notadamente quando elas são qualificadas como aptas a gerar confiança. 
Analisados os possíveis comportamentos das partes, e considerando que o venire não tutela qualquer contradição, mas apenas aquela de que decorra quebra de expectativas, foi preciso fixar quais expectativas o sistema processual nos permite ter com relação ao comportamento dos sujeitos processuais.

E, apesar de nem sempre as partes e o órgão julgador comportarem-se espontaneamente em observância aos ditames da boa-fé objetiva e da cooperação, tais princípios são imperativos no ordenamento processual, viabilizando que se exijam dos sujeitos processuais condutas assim qualificadas. Dessa maneira, quando se pratica determinada situação jurídica processual, presume-se que ela é convergente com a boa-fé e com a cooperação, nascendo assim a expectativa a ser tutelada.

Visto como se comportam os sujeitos processuais - e assim, como podem se contradizer - e quais as expectativas processuais a serem tuteladas, começam a ser delineados os contornos do venire processual. Mas, antes de bem delimitá-los, foi preciso investigar a funcionalidade de outras figuras existentes no sistema processual que tem por escopo a repressão de condutas indesejadas no processo.

O abuso do processo configura-se quando os sujeitos processuais, legitimados a agir, exercem posições jurídicas aparentemente legais, mas que se tornam ilícitas diante do desvio de finalidade. Tal como ocorre com o abuso de direito, o abuso do processo representa um limite à liberdade processual de agir, e um dos parâmetros para se aferir o desvio de finalidade é, igualmente, a boa-fé objetiva processual. Dessa maneira, o venire processual se posiciona como uma modalidade de abuso do processo, pela afronta à boa-fé, do que se conclui que o abuso do processo é gênero, do qual o venire processual é espécie.

O venire atua em serviço da probidade na medida em que este conceito abarca todos os valores desejados no processo e que se referem à conduta das partes, tais como boa-fé, cooperação, lealdade, honestidade, etc. Por sua ampla abrangência, porém, preferimos nos ater a princípios mais individualizados, como a boa-fé e a cooperação.

O venire, como modalidade de abuso do processo, não deixa de ser um ilícito processual, mas desde que se destaque a concepção de ilícito não como mera afronta à lei, mas também como afronta a valores norteadores do ordenamento jurídico.

Sobre a litigância de má-fé, após nos posicionarmos no sentido de que a figura não requer necessariamente a investigação do íntimo do agente para ser configurada, bem como que ela nada mais representa do que casos expressos em lei de exercícios abusivos 
de situações jurídicas processuais, concluimos que a litigância de má-fé integra a categoria de abuso do processo. E, sendo o venire contra factum proprium uma forma de abuso do processo, justifica-se a aplicação ao venire das sanções previstas para a litigância de má-fé.

Ao estudamos a valoração judicial da conduta das partes, vimos que se trata de um mecanismo auxiliador da formação do convencimento do magistrado, por meio do qual a conduta das partes é tida como um indício, indício sobre o qual se aplicam regras de experiência, e, com base nisso, formam-se presunções aptas a formar ou reforçar uma decisão judicial.

E, ao compararmos a valoração judicial da conduta das partes com o venire processual, vimos que são figuras não coincidentes pelo fato de (i) o venire exigir duas condutas que, pela contradição, (ii) afrontem a boa-fé - o que não é necessária realidade na valoração, que pode se basear em uma só conduta, e, ainda, pode haver valoração de comportamento em consonância com a boa-fé; (iii) por ele não ter por consequência apenas auxiliar a formação da convicção do magistrado - função que eventualmente pode assumir; bem como (iv) pelo juiz poder atuar de maneira contraditória, condutas que não terão qualquer relevância probatória; e porque (v) o venire poder se configurar a partir de condutas praticadas em outros processo.

Quanto à autocontradicción ou intercadencia, trata-se de instituto similar ao da valoração judicial de condutas, não fosse a diferenciação doutrinária que admite a caracterização da intercadencia com base em alegações e comportamentos praticados não só no curso do processo, mas também fora dele. Essas figuras, sinônimas entre si, são definidas de maneira ampla como um meio atípico de prova, a qual é construída a partir de presunções fundadas em indícios específicos, quais sejam, as contradições entre alegações ou condutas das partes.

A intercadencialautocontradicción aproxima-se de nosso objeto de estudo quando comparada com a valoração judicial da conduta na medida em que também requer condutas contraditórias para sua configuração, bem como porque não limita a contradição a uma mesma sede processual. Contudo, mantém-se como figura distinta pelas demais diferenciações feitas com relação à valoração judicial da conduta, aplicáveis também à intercadencia ou autocontradicción.

O estoppel é figura proveniente da common law e bastante ampla, aplicável a diversos contextos de direito material, bem como servindo de base para diferentes 
funcionalidades no Processo Civil. Interessa-nos sua função como rule of evidence, hipótese em que o estoppel assume as vestes de uma regra de prova no processo, de modo a vedar que um sujeito alegue a falsidade de situação que ele mesmo criara a partir de suas palavras ou condutas. Essa vedação se dá por meio da construção de uma presunção absoluta de que a situação criada é verdadeira, impedindo-se as tentativas de demonstração em sentido contrário.

Apesar da estreita semelhança entre venire processual e o estoppel, preferimos não afirmar com precisão essa relação na medida em que nossas fontes de pesquisa foram insuficientes para compreender a figura do estoppel como rule of evidence com plena segurança. Ressaltamos, contudo, que as presunções construídas a partir do venire não têm natureza absoluta, como ocorre no estoppel.

Chegado o momento de realizar a comparação entre preclusão lógica e venire, foi preciso dedicar grande parte do estudo à compreensão do fenômeno da preclusão, pois desde o princípio ressaltamos que, a depender do que se entenda por preclusão, sua relação com o venire processual pode ser mais próxima ou mais distante.

E, por meio da análise da doutrina majoritária sobre o tema, foi destacado, em caráter introdutório, que: (i) preclusão para as partes e preclusão para o juiz são fenômenos bastante distintos; (ii) a finalidade essencial atribuída à preclusão é garantir o impulso do processo, a marcha processual e (iii) a eficácia da preclusão, seja das partes seja a do juiz, é endoprocessual.

No que se refere à preclusão para as partes, elas incidem sobre os ônus processuais. Ela é classificada tradicionalmente entre preclusão temporal, consumativa e lógica, mas, para nós, a modalidade consumativa é prescindível no ordenamento.

No que concerne à preclusão para o juiz, trata-se da impossibilidade de reapreciar questões já decididas no curso do processo, entendendo-se por questões aquelas com o mesmo ponto de fato ou de direito, o mesmo suporte fático-jurídico e o mesmo suporte probatório. O fato gerador da preclusão para o juiz é a simples consumação, ou seja, o fato de uma questão já ter sido decidida impede sua reapreciação.

As preclusões para o juiz, para a maior parte da doutrina, são excepcionadas em uma série de hipóteses, já referidas. Para nós, porém, ela se excepciona somente em casos de previsão legal expressa permissiva da retratação, bem como quanto a decisões que representem o exercício do poder administrativo do juiz e quanto a decisões que indefiram 
a produção de determinada prova. Vimos, ainda, que não existem decisões implícitas no nosso ordenamento, pois isso feriria o princípio da motivação das decisões judiciais, de modo que não pode existir preclusão que implique vedação à apreciação de questões ainda não decididas.

Com base na definição dessas premissas, tornou-se possível comparar preclusão e venire.

Sobre o venire e a preclusão lógica, a maneira como hoje esta é compreendida pela maioria da doutrina brasileira distancia-se da vedação de comportamentos contraditórios, uma vez que (i) não tem posição de destaque a ponto de enaltecer a proteção de expectativas fundadas na boa-fé e cooperação como deveria, já que essa é a finalidade do venire; (ii) tem efeitos limitados às barreiras endoprocessuais; (iii) não se configura a partir de um comportamento omissivo ou outras situações jurídico processuais que não o ônus e (iv) em verdade, revela-se apenas uma das possíveis consequências da adoção do comportamento processual contraditório. Concluimos, então, que a preclusão lógica está inserida no contexto da vedação de comportamentos processuais contraditórios, mas esta é mais abrangente.

No que diz respeito à relação entre venire e preclusão para o juiz, ressaltamos que as figuras são distintas porque (i) o venire pode ser aplicado mesmo nos espaços em que há exceção à preclusão para o juiz; (ii) há casos de contradição afrontadora de expectativas não resolvidos pela preclusão porquanto as decisões que se contradizem não se referem a uma mesma questão; (iii) existe venire por omissão decisória do juiz, ao passo que inexiste preclusão a partir da não decisão; e (iv) o venire do juiz pode se estender para além das barreiras endoprocessuais, vinculando processos distintos, que preencham os requisitos necessários à reunião de processos.

No Capítulo 8, por fim, buscamos sistematizar tudo que foi dito, a fim de cumprir nosso objetivo de esclarecer a forma de utilização da teoria da vedação de comportamentos contraditórios em âmbito processual.

A primeira ideia fixada foi a de que, tal como ocorre no Direito Civil, a vedação de condutas processuais contraditórias só tem razão de ser quando, por meio da contradição, forem feridas expectativas processuais, i.e., quando rompida a confiança que o sistema processual nos permite ter de que os sujeitos atuarão segundo os ditames da boafé e da cooperação. Daí a imprescindibilidade da análise do caso concreto, porquanto 
somente diante dele haverá uma apreciação valorativa da existência ou não de quebra de expectativas processuais. E essa contradição afrontadora de expectativas é aferida objetivamente, ou seja, sem qualquer análise das intenções do sujeito que se contradisse.

Nesse ponto, estudamos especificamente o tema da regra da eventualidade, o maior exemplo de como somente o caso concreto será capaz de indicar a permissividade ou não da contradição. Via de regra, a eventualidade permite contradições, mas elas não podem ser exercidas de forma tal a romper expectativas processuais. Dessa forma, a eventualidade, tal como qualquer outra contradição processual, é permitida desde que não haja afronta à confiança investida no curso da relação jurídica processual.

Destacada a função da vedação de comportamentos contraditórios, foi preciso descrever como ela se operacionaliza, ou seja, quais as situações jurídicas processuais que uma vez exercidas ensejam a possibilidade de aplicação do venire processual.

No que concerne às partes, e como já adiantamos ainda nesta conclusão, a atuação contraditória a um dever ou sujeição não gera possibilidade de configuração de venire processual, porquanto condutas ou omissões não voluntárias não permitem que sejam emitidas expectativas vinculantes.

Desse modo, o factum proprium pode representar o exercício de um ônus, faculdade ou poder, e ainda, pode ser uma conduta extraprocessual, que venha a produzir efeitos em um processo quando da contradição nele exercida. Assim, para que se caracterize o venire processual, é preciso que a confiança seja rompida no processo, ou seja, que a segunda conduta seja processual, mas o factum proprium pode ser praticado (i) dentro do mesmo processo em que houve a prática do ato contraditório; (ii) dentro de uma sede processual diversa, i.e., em outro processo, anterior ou conexo; (iii) ou até mesmo fora de qualquer sede processual.

O factum proprium pode, por fim, ser uma omissão, conforme já sinalizado. Mas, para que essa omissão seja conclusiva - i.e., capaz de gerar a expectativa de que a conduta não mais será praticada -, é preciso que se configure situação em que a parte, podendo agir no exercício de uma posição jurídica ativa, e sendo exigível a atuação porquanto conduta esperada de qualquer homem médio, mantém-se inerte. Assim, para que haja venire processual por omissão, é preciso: (i) que se trate de uma posição jurídica de vantagem (não sendo, pois, ônus, dever ou sujeição); (ii) que a parte tenha se mantido inerte quanto ao seu exercício e (iii) que as circunstâncias indiquem que a conduta 
esperada, à luz da boa-fé, era justamente o exercício dessa posição, o que permitirá se falar em omissão geradora de expectativas a serem tuteladas por meio da vedação à contradição.

Destacou-se, ainda quanto ao venire das partes, que não precisa haver necessária coincidência entre o sujeito remetente da confiança e o que se contradiz, bastando que ambos pertençam ao mesmo polo de interesse. E mitigada a coincidência entre o destinatário da conduta vinculante e o que presencia a conduta posterior, principalmente porque o órgão julgador é também sujeito passivo do venire processual.

No tocante à contradição do órgão julgador, já vimos em quais contextos ela pode ocorrer, quais sejam, aqueles em que a preclusão se mostra insuficiente a obstar a contradição. No caso de venire processual do juiz, e ressalvando a limitação deste trabalho quanto à análise micro da função jurisdicional, é irrelevante a coincidência de remetentes ou destinatários da confiança.

O venire processual, seja das partes, seja do juiz, requer que haja adesão a confiança originada a partir do factum proprium, mas, diferentemente do que ocorre no Direito Civil, essa adesão é pressuposta conforme seguem-se os atos processuais previstos no procedimento a ser adotado sem que tenha havido qualquer ressalva pelos sujeitos processuais.

Há contradição simultânea ao factum proprium, porém com a peculiaridade de que, ao nos depararmos com dois atos contraditórios praticados em simultaneidade, há uma situação de desconfiança em ambos os atos, de modo que apenas um deles deve prevalecer para que se possa reestabelecer a boa-fé e a cooperação processual. Assim, o reconhecimento do venire servirá para evitar que o procedimento tenha continuidade convivendo com uma situação contraditória afrontadora de expectativas. E, ao afastarmos uma situação de desconfiança, o venire continua cumprindo seu papel de tutelar a confiança processual, reestabelecendo-a.

O venire processual é subsidiário, sem que precise ser aplicado quando o legislador já positivou situações de vedação à contradição.

Vistas todas essas características, foram apontadas as consequências possíveis diante da identificação da contradição processual que afronte expectativas decorrentes da boa-fé e da cooperação: (i) o óbice à produção de efeitos da conduta contraditória - sendo que somente essa é a consequência aplicável ao venire do órgão julgador; (ii) a imposição de sanções pecuniárias e (iii) a valoração da conduta contraditória. 
E, por fim, analisadas as limitações à aplicabilidade do venire processual, o que ocorrerá quando (i) faltar liberdade às condutas contraditórias praticadas; (ii) houver ressalva motivada quanto à possibilidade de posterior contradição; (iii) a lei expressamente permitir a contradição, sem ressalvas; (iv) houver conflito entre a boa-fé e a cooperação processual e outros valores igualmente relevantes ao processo.

Com isso, conclui-se este trabalho que buscou analisar essa ferramenta à disposição do sistema processual para prevenir e reprimir condutas processuais contraditórias que afrontem expectativas processuais. 


\section{REFERÊNCIAS}

ABDO, Helena Najjar. O abuso do processo. São Paulo: Editora Revista dos Tribunais, 2007.

Fundamentos sistemáticos do abuso do processo no direito processual civil. Dissertação (Mestrado em Direito). Faculdade de Direito, Universidade de São Paulo. São Paulo, 2002.

- As situações jurídicas processuais e o processo civil contemporâneo. In DIDIER JR., Fredie (coord.), Teoria do Processo: panorama doutrinário mundial, v. 2. Salvador: Juspodivm, 2010, pp. 338-352.

ACOSTA, Daniel Fernando. La conducta procesal de las partes como concepto atinente a la prueba. In PEYRANO, Jorge W. e ACOSTA, Daniel Fernando (coords.), Valoración judicial de la conducta procesal. $1^{\mathrm{a}} \mathrm{ed}$. Santa Fe: Rubinzal-Culzoni, 2005, pp. 78-115.

AFONSO E SILVA, Virgílio. Direitos fundamentais: conteúdo essencial, restrições e eficácia. $2^{\mathrm{a}}$ ed., São Paulo: Malheiros, 2010.

Princípios e regras: mitos e equívocos acerca de uma distinção. In Revista Latino-Americana de Estudos Constitucionais, n. 1, Del Rey, pp. $607-$ 630, jan/jul.2003.

AGUIAR JÚNIOR, Ruy Rosado. Proteção da boa-fé subjetiva. In Revista da Ajuris, Porto Alegre, v. 39, n. 126, jun. 2012.

AIRASCA, Ivana María. Reflexiones sobre la proscripción del abuso del derecho en el proceso. In PEYRANO, Jorge W., RAMBALDO, Juan Alberto (coords.), Abuso procesal. Buenos Aires: Rubinzal-Culzoni, 2006, pp. 89-114.

ALBERTO, Misael E. Valor probatorio de la conducta em juicio. In PEYRANO, Jorge W. e ACOSTA, Daniel Fernando (coords.), Valoración judicial de la conducta procesal. $1^{\mathrm{a}} \mathrm{ed}$. Santa Fe: Rubinzal-Culzoni, 2005, pp. 117-140.

ALBUQUERQUE, Pedro de. Responsabilidade processual por litigância de má-fé, abuso de direito e responsabilidade civil em virtude de actos praticados no processo. Coimbra: Almedina, 2006.

ALEXY, Robert. Teoria dos direitos fundamentais. Tradução de Virgílio Afonso da Silva. São Paulo: Malheiros, 2008.

ALVARO DE OLIVEIRA, Carlos Alberto. Poderes do juiz e visão cooperativa do processo. In Revista da Ajuris, ano 30, v. 90, pp. 55-84, jun. 2003. 
Do formalismo no processo civil: proposta

de um formalismo-valorativo. $4^{\mathrm{a} e d ., ~ S a ̃ o ~ P a u l o: ~ S a r a i v a, ~} 2010$.

ALVIM, Arruda. Deveres das partes e dos procuradores, no direito processual civil brasileiro. In Revista de processo, ano 18, n. 69, pp. 7-19, jan./mar.1993.

AMERICANO, Jorge. Do abuso do direito no exercicio da demanda. São Paulo: Casa Vanorden, 1923.

ANGHER, Anne Joyce. Litigância de má-fé no processo civil. São Paulo: Rideel, 2005.

APRIGLIANO, Ricardo de Carvalho. Ordem pública e processo: o tratamento das questões de ordem pública no direito processual civil. São Paulo: Atlas, 2011.

AROCA, Juan Montero. El proceso civil llamado "social" como instrumento de "justicia" autoritária. In Proceso Civil e Ideología: un prefacio, una sentencia, dos cartas y quince ensayos, Valencia, Tirant lo blanch, pp. 129-165, 2006.

Sobre el mito autoritario de la "buena fe processal". In Proceso Civil e Ideología: un prefacio, una sentencia, dos cartas y quince ensayos, Valencia, Tirant lo blanch, pp. 293-353, 2006.

ÁVILA, Humberto. Teoria dos princípios: da definição à aplicação dos princípios jurídicos. $10^{\text {a }}$ ed. São Paulo: Malheiros, 2009.

BARBI, Celso Agrícola. Da preclusão no processo civil. In Revista Forense, ano 52, v. 58, mar./abr.2005, pp. 59-66.

BARBIERI, Maurício Lindenmeyer. Implicações do princípio dispositivo nos poderes instrutórios do juiz. In OLIVEIRA, Carlos Aberto Alvaro de (coord.), Prova cível. Rio de Janeiro: Forense, 2005.

BARBOSA MOREIRA, José Carlos. O neoprivatismo no processo civil. In Temas de Direito Processual (nona série). São Paulo: Saraiva, 2007.

O problema da 'divisão do trabalho' entre juiz e partes: aspectos terminológicos. In Temas de direito processual: Quarta série. São Paulo: Saraiva, 1989.

O processo civil contemporâneo: um enfoque comparativo. In Temas de direito processual: Nona série. São Paulo: Saraiva, 2007.

Questões prejudiciais e coisa julgada. Tese para obtenção do grau de livre docente da Faculdade de Direito da Universidade Federal do Rio de Janeiro, 1967. 
BARROS e SILVA, Rafael Santos de. O controle das expectativas dos jurisdicionados: impedindo o venire contra factum proprium do Poder Judiciário. In Revista de Direito e Política, São Paulo, v. 20, pp. 93-199, jan./jun.2011.

BARROSO, Alexandre de Alencar Barroso. Acesso à justiça e preclusão civil, Dissertação para obtenção do grau de mestre no curso de Pós-Graduação da Faculdade de Direito da Universidade de São Paulo, 1996.

BEDAQUE, José Roberto dos Santos. Direito e Processo: influência do direito material sobre processo. $4^{\mathrm{a}} \mathrm{ed}$. São Paulo: Malheiros, 2006.

Editora Revista dos Tribunais, 2009. Poderes instrutórios do juiz. $4^{\mathrm{a}}$ ed. São Paulo:

São Paulo: Malheiros, 2010.

Efetividade do processo e técnica processual. $3^{\mathrm{a}} \mathrm{ed}$.

BERALDO, Maria Carolina Silveira. O comportamento dos sujeitos processuais como obstáculo à razoável duração do processo. São Paulo: Saraiva, 2013.

BOBBIO, Norberto. Da estrutura à função: novos estudos de teoria do direito. São Paulo: Manole, 2007.

BORDA, Alejandro. La teoria de los actos propios. $2^{\mathrm{a}}$ ed. Buenos Aires: Abeledo-Perrot, 1993.

CABRAL, Antonio do Passo. O contraditório como dever e a boa-fé processual objetiva. In Revista de Processo - RePro, São Paulo, ano 30, n. 126, pp. 59-81, ago. 2005.

. Nulidades no processo moderno: contraditório, proteção da confiança e validade prima facie dos atos processuais. Rio de Janeiro: Forense, 2009.

. Coisa julgada e preclusões dinâmicas: entre continuidade, mudança e transição de posições jurídicas processuais estáveis. Salvador: Juspodivm, 2013.

CAIS, Fernando Fontoura da Silva. Preclusão e instrumentalidade do processo. Dissertação para obtenção do grau de mestre no curso de Pós-Graduação da Faculdade de Direito da Universidade de São Paulo, 2006.

CAMBI, Eduardo. Verdade processual objetivável e limites da razão jurídica iluminista. In Revista de Processo, São Paulo, ano 24, n. 96, pp. 234-249, out./dez. 1999.

dos Tribunais, 2006.

. A prova civil: admissibilidade e relevância. São Paulo: Editora Revista

CAMPOS, Paulo Cerqueira. A preclusividade dos poderes do juiz como uma das formas de se conferir efetividade ao atual processo civil brasileiro. In Revista de doutrina e de 
jurisprudência do Tribunal de Justiça do Distrito Federal e dos Territórios, vol. 75, mai./ago. 2004, pp. 17-43.

CARRADITA, André Luis Santoro. Abuso de situações jurídicas processuais no Código de Processo Civil. Dissertação (Mestrado em Direito). Faculdade de Direito, Universidade de São Paulo. São Paulo, 2013.

CASTRO FILHO, José Olímpio de. Abuso do Direio no Processo Civil. Rio de Janeiro: Forense, 1960.

CATALANO, Elena Maria. L’abuso del processo. Milão: Giuffrè Editore, 2004.

CHIAPPINI, Julio O., La doctrina de los proprios actos: errores. In CHIAPPINI, Julio O., Cuestiones sobre la prueba civil CPCN. Santa Fe: Jurídica Panamericana, 2006, pp. 699703.

CHIOVENDA, Giuseppe. Cosa giudicata e preclusione. In Saggi di Diritto Processuale Civile, v. 3. Milão: Giuffrè, 1993, pp. 231-283.

CHIOVITTI, Ana Paula. A boa-fé no Processo Civil e os mecanismos de repressão ao dolo processual. Dissertação (Mestrado em Direito). Faculdade de Direito, Pontifícia Universidade Católica de São Paulo. São Paulo, 2009.

COLOMBO, Carlos J. Inconducta procesal: temeridad o malicia. In CÓRDOBA, Marcos M., CORDOBERA, Lidia M. Garrido, KLUGER, Vivian (coords.), Tratado de la Buena Fe em el Derecho. $1^{\mathrm{a}}$ ed, v. 1. Buenos Aires: La Ley, 2004, pp. 823-839.

COOKE, Elizabeth. The modern law of estoppel. Nova York: Oxford University Press, 2003.

CORDEIRO, António Manuel da Rocha e Menezes. Da boa-fé no Direito Civil. 3 ed. Coimbra: Almedina, 2007.

Direito de Ação e Culpa "In Agendo”. 2a ed.Coimbra: Almedina, 2011.

Litigância de má-fé, Abuso do

CORNERO, Guillermina. Valor probatorio de la conducta procesal. In PEYRANO, Jorge W. e ACOSTA, Daniel Fernando (coords.), Valoración judicial de la conducta procesal. $1^{\mathrm{a} e d . ~ S a n t a}$ Fe: Rubinzal-Culzoni, 2005, pp. 207-218.

COSTA, Suzana Henriques da. Condições da ação. São Paulo: Quartier Latin, 2005.

COSTA E SILVA, Paula. Acto e processo: o dogma da irrelevância da vontade na interpretação e nos vícios do acto postulativo. Coimbra: Coimbra, 2003.

A litigância de má-fé. Coimbra: Coimbra: 2008. 
COUTO E SILVA, Clóvis. A obrigação como processo. Rio de Janeiro: Editora FGV, 2006.

COUTURE, Eduardo J., Fundamentos de derecho procesal civil. $3^{\mathrm{a}}$ ed. Buenos Aires: Roque Depalma, 1958.

CUNHA, Alcides Munhoz da. Correlação lógica entre cognição, preclusão e coisa julgada. In Revista de Processo, ano 33, n. 163, set.2008, pp. 359-375.

CUNHA, Leonardo Carneiro da. A colaboração do executado no processo. In WAMBIER, Teresa Arruda Alvim; BUENO, Cassio Scarpinella Bueno (coords.), Aspectos polêmicos da nova execução, v. 4. São Paulo: Editora Revista dos Tribunais, 2008, pp. 273-285.

CUNHA DE SÁ, Fernando Augusto. Abuso do direito. Lisboa: Centro de Estudos do Ministério das Finanças, 1973.

DANTAS JÚNIOR, Aldemiro Rezende. Teoria dos atos proprios no princípio da boa-fé. Curitiba: Juruá, 2009.

DE LOS MOZOS, José Luis. Metodologia y ciência en el derecho privado moderno. Madrid: Editorial Revista de Derecho Privado, 1977.

DE VINCENZI, Brunela Vieira. A boa-fé no processo civil. São Paulo: Atlas, 2003.

DICKSTEIN, Marcelo. As funções da boa-fé objetiva e a proibição de comportamento contraditório. In Revista de Direito do Tribunal de Justiça do Estado do Rio de Janeiro, Rio de Janeiro, Espaço Jurídico, n. 1º, jun. 1985.

DIDIER JR., Fredie. Cláusulas gerais processuais. In JAYME, Fernando Gonzaga; DE FARIA, Juliana Cordeiro; LAUAR, Maira Terra (coords.), Processo Civil: novas tendências (Homenagem ao Ministo Sálvio de Figueiredo Teixeira). Belo Horizonte: Del Rey, 2011, pp. 269-280.

Fundamentos do Princípio da Cooperação no Direito Processual Civil Português. Coimbra: Coimbra, 2010.

Os três modelos de direito processual: inquisitivo, dispositivo e cooperativo. In Revista de Processo, São Paulo n. 198, pp. 213-225, ago. 2011.

O princípio da cooperação: uma apresentação. In Revista de Processo, São Paulo, ano 30, n. 127, pp. 75-79, set. 2005.

. Subsídios para uma teoria das impenhorabilidades. In Revista de Processo, São Paulo, n. 174 pp. 30-50, ago. 2009.

Multa coercitiva, boa-fé processual e supressio: aplicação do duty to mitigate the loss no processo civil. In Revista de Processo, São Paulo, v. 34, n. 171, pp. 35-48, maio 2009. 
Alguns aspectos da aplicação da proibição do venire contra factum proprium no processo civil. In FARIAS, Cristiano Chaves de., Leituras Complementares de Direito Civil. Salvador: Juspodivm, pp. 199-207.

Curso de direito processual civil, v. 1. 14 a ed. Salvador: Juspodivm,

2012.

Tópicos sobre a última reforma processual (dezembro de 2006): (parte 1). In Revista de Processo, São Paulo, v. 32, n. 147, p. 164-174, maio 2007.

DIDIER JR., Fredie; NOGUEIRA, Pedro Henrique Pedrosa. Teoria dos fatos jurídicos processuais. Salvador: Juspodivm, 2011.

DÍEZ-PICAZO, Luis Ponce de León. La doctrina de los propios actos: un estudo critico sobre la jurisprudencia del tribunal supremo. Barcelon: Bosch, 1963.

DINAMARCO, Cândido Rangel; CINTRA, Antônio Carlos de Araújo; GRINOVER, Ada Pellegrini. Teoria Geral do Processo. 24a ed. São Paulo: Malheiros, 2008.

DINAMARCO, Cândido Rangel. A instrumentalidade do processo. $14^{\mathrm{a}}$ ed. São Paulo: Malheiros, 2009.

Paulo: Malheiros, 2009. Instituições de direito processual civil, v. II. $6^{\mathrm{a}} \mathrm{ed}$. São edição. São Paulo, Malheiros, 2009.

Instituições de Direito Processual Civil, v. III, $6^{\mathrm{a}}$

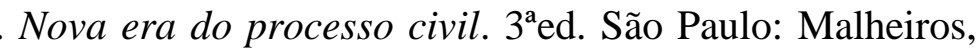
2009.

DINAMARCO, Pedro. Ônus processuais: limites à aplicação das consequências previstas para seu não-cumprimento. Tese para obtenção do grau de doutor no curso de PósGraduação da Faculdade de Direito da Universidade de São Paulo, 2007.

DOLINGER, Jacob. Direito internacional privado: parte geral. $10^{\mathrm{a}}$ ed. Rio de Janeiro: Forense, 2011.

DORIA, Rogéria Dotti. A litigância de má-fé e a aplicação de multas, pp. 648-655. In MARINONI, Luiz Guilherme (coord.), Estudos de Direito Processual Civil: homenagem ao Professor Egas Dirceu Moniz de Aragão. São Paulo: RT, 2005.

FABRÍCIO, Adroaldo Furtado. Fatos notórios e máximas de experiência. In YARSHELL, Flávio Luiz e MORAES, Mauricio Zanoide de (coords.), Estudos em homenagem à Professora Ada Pelegrini Grinover. São Paulo: DPJ Editora, 2005, pp. 431-441. 
FAURE, Miryam T. Balestro. La valoración judicial de la conducta en juicio. In PEYRANO, Jorge W. e ACOSTA, Daniel Fernando (coords.), Valoración judicial de la conducta procesal. $1^{\text {a }}$ ed. Santa Fe: Rubinzal-Culzoni, 2005, pp. 25-44.

FAVARETTO, Isolde. Comportamento processual das partes como meio de prova. Porto Alegre: Editora Acadêmica, 1993.

FILHO, Manoel Caetano Ferreira. A preclusão no direito processual civil. Curitiba: Juruá Editora, 1991.

FRADA, Manuel António de Castro Portugual Carneiro da. Teoria da confiança $e$ responsabilidade civil. Coimbra: Almedina, 2004.

FREITAS, José Lebre de. Introdução ao Processo Civil: conceitos e princípios gerais. $2^{\mathrm{a}}$ ed. Coimbra: Coimbra, 2012.

GARCÍA, Enrique Vallines. La preclusión en el proceso civil. Madrid: Civitas, 2004.

GREGER, Reinhard. Cooperação como princípio processual. In Revista de Processo, ano 37, n. 206, abr.2012, pp. 123-134.

GIANNICO, Mauricio. A preclusão no direito processual civil brasileiro. $2^{\mathrm{a}}$ ed. São Paulo: Saraiva, 2007.

GODOY, Claudio Luis Bueno de. Função social do contrato: os novos princípios contratuais. São Paulo: Saraiva, 2004.

GOLDSCHMIDT, James. Derecho procesal civil. Trad. Leonardo Prieto Castro. Barcelona: Labor, 1936.

GONÇALVES, Camila de Jesus Mello. Princípio da boa-fé: perspectivas e aplicações. Rio de Janeiro: Elsevier, 2008.

GOUVEIA, Mariana França. Os poderes do juiz cível na acç̧ão declarativa: em defesa de um processo civil ao serviço do cidadão. In Julgar, Lisboa, n. 1, pp. 47-65, 2007.

GOZAÍNI, Osvaldo Alfredo. La conducta en el processo. Buenos Aires: Libreria Platense S.R.L., 1988.

El principio de la buena fe en el proceso civil. In CÓRDOBA, Marcos M., CORDOBERA, Lidia M. Garrido, KLUGER, Vivian (coords.), Tratado de la Buena Fe em el Derecho. $1^{\text {a }}$ ed, v. 1. Buenos Aires: La Ley, 2004, pp. 891911.

GRASSI DE GOUVEA, Lúcio. Cognição processual civil: atividade dialética $e$ cooperação intersubjetiva na busca da verdade real. In Leituras Complementares de Processo Civil, 8 a edição. Salvador: Editora Juspodivm, 2010. 
GRECO, Leonardo. Publicismo e privatismo no processo civil. In Revista de Processo, São Paulo, ano 33, n. 164, pp. 29-56, out. 2008.

GRASSO, Eduardo. La collaborazione nel processo civile. In Rivista di diritto processuale. Padova, Cedam, pp. 580- 609, out./dez. 1966.

GROSSMANN, Kaethe. O dever de veracidade das partes litigantes no processo civil (aspecto doutrinário). In Revista Forense 101, Rio de Janeiro, pp. 476-483, mar. 1945.

HEÑIN, Fernando Adrián. Valoración judicial de la conduta procesal. In Revista de processo. São Paulo, v. 170, pp. 59-93, abri.2009.

2009. Modernos institutos procesales. Resistencia: ConTexto Libros,

HOFFMAN, Paulo. Saneamento compartilhado. São Paulo: Quartier Latin do Brasil, 2011.

INGRAO, Giuseppe. La valutazione del comportamento delle parti nel processo tributario. Milão: Giuffrè editore, 2008.

IOCOHAMA, Celso Hiroshi. Litigância de má-fé e lealdade processual. Curitiba: Juruá Editora, 2006.

JOLOWICZ, John Anthony. Modelos adversarial e inquisitorial de processo civil. In Revista Forense 372, Rio de Janeiro, pp.136-147, 2004.

JUNQUEIRA DE AZEVEDO, Antonio. Novos estudos e pareceres de direito privado. São Paulo: Saraiva, 2009.

LACERDA, Galeno. Despacho saneador. $3^{\mathrm{a} e d . ~ P o r t o ~ A l e g r e: ~ S e r g i o ~ A n t o n i o ~ F a b r i s, ~}$ 1990.

LENT, Friedrich. Diritto processuale civil tedesco: parte prima. Trad. Edoardo F. Ricci. Nápole: Morano, 1962.

LIEBMAN, Enrico Tullio. Manual de Direito Processual Civil, vol. I. $3^{\text {a }}$ ed. São Paulo: Malheiros, 2005.

LIMA, Alcides de Mendonça. O princípio da probidade no Código de Processo Civil brasileiro. In Revista de processo, ano IV, n. 16, out./dez.1979, pp. 15-42.

LIMA, Bernardo Silva de. Sobre o negócio jurídico processual. In DIDIER JR., Fredie (coord.), Teoria do Processo: panorama doutrinário mundial, v. 2. Salvador: Juspodivm, 2010, pp. 115-123.

LOPES, João Batista. Breves considerações sobre o instituto da preclusão. In Revista de Jurisprudência do Tribunal de Justiça do Estado de São Paulo, ano 16, vol. 76, mai/jun. 1982. 
MACHADO, Marcelo Pacheco. Ônus estático, ônus dinâmico e inversão do ônus da prova: análise crítica do Projeto de novo Código de Processo Civil. In Revista de processo, ano 37, n. 208, jul.2008, pp. 295-316.

MALACHINI, Edson Ribas. Alegações imprecluíveis e dever judicial de cognição ex officio. In Revista Forense, ano 104, vol. 395, jan./fev.2008, pp. 67-93.

MARINONI, Luiz Guilherme. O precedente na dimensão da igualdade. In A força dos precedentes - estudos dos cursos de mestrado e doutorado em direito processual civil da UFPR. Salvador: Juspodivm, 2010, pp. 227-247.

MARINONI, Luiz Guilherme; ARENHART, Sérgio Cruz. Prova. São Paulo: Editora Revista dos Tribunais, 2009.

MARINONI, Luiz Guilherme; MITIDIERO, Daniel. O projeto do CPC: críticas $e$ propostas. São Paulo: Editora Revista dos Tribunais, 2010.

Propriedade industrial. Boa-fé objetiva. Proteção da confiança. Proibição do venire contra factum proprium no processo. Dever de não conhecer do recurso. In Revista brasileira de direito processual, Belo Horizonte, ano 16, n. 61, jan./mar. 2008, pp. 181-193.

MARQUES, José Frederico. Manual de direito processual civil, v. I. 9ªd. Campinas: Millennium, 2003.

Millennium, 2003.

. Manual de direito processual civil, v. II. 9ª ed. Campinas:

MARQUES, Silvia Pereira. Reflexiones acerca de algunos aspectos de la valoración de la conducta procesal de las partes desplegada en procesos distintos (conexos o no). In PEYRANO, Jorge W. e ACOSTA, Daniel Fernando (coords.), Valoración judicial de la conducta procesal. $1^{\text {a }}$ ed. Santa Fe: Rubinzal-Culzoni, 2005, pp. 313-324.

MARTINS, FLÁVIO ALVES. A Boa-fé objetiva e sua formalização no Direito das Obrigações Brasileiro. Rio de Janeiro: Editora Lumen Juris, 2000.

MARTINS-COSTA, Judith. A ilicitude derivada do exercício contraditório de um direito: o renascer do venire contra factum proprium. In Revista Forense, Rio de Janeiro, ano 100, v. 376, pg. 109-129, nov./dez. 2004.

dos Tribunais, 2000.

. A boa fé no Direito Privado. $1^{\text {a }}$ ed. São Paulo: Editora Revista

MASCIOTRA, Mario. La conducta procesal de las partes. Buenos Aires: Ad-Hoc, 2005.

MESA, Marcelo J. López. La doctrina de los actos propios: esencia y requisitos de aplicación. In Vuniversitas, Bogotá, v. 199, pg. 189-222, jul./dez. 2009. 
MESA, Marcelo J. López; VIDE, Carlos Rogel. La doctrina de los actos propios: doctrina y jurisprudencia. Buenos Aires: Editorial Reus, 2009.

MILHOMENS, Jônatas. Da presunção de boa-fé no processo civil. Rio de Janeiro: Forense, 1961.

MILMAN, Fabio. Improbidade processual: comportamento das partes e de seus procuradores no processo civil. $2^{\mathrm{a}}$ ed. Rio de Janeiro: Forense, 2009.

MITIDIERO, Daniel. Colaboração no Processo Civil. $2^{\mathrm{a}}$ ed. São Paulo: Editora Revista dos Tribunais, 2009.

MONIZ DE ARAGÃO, Egas Dirceu. Preclusão (processo civil), In Saneamento do processo - estudos em homenagem ao professor Galeno Lacerda. Porto Alegre: Sergio Antonio Fabris, 1989, pp. 141-183.

MUÑOZ, Franceso Carretta. Deberes procesales de las partes en el proceso civil chileno: referencia a la buena fe procesal y al deber de coeherencia. In Revista de Derecho, Valdivia, v. XXI, n. 1, jul.2008, pp. 101-127.

NASCIMENTO, José Moacyr Doretto. A boa-fé objetiva e o processo civil. In Ciência Jurídica, Belo Horizonte, n. 163, pp. 62-108, jan./fev.2012.

NEGREIROS, Teresa. Fundamentos para uma interpretação constitucional do princípio da boa-fé. Rio de Janeiro: Renovar, 1998.

NERY JUNIOR, Nelson. Boa-fé objetiva e segurança jurídica - eficácia da decisão judicial que altera jurisprudência anterior do mesmo tribunal superior. In FERRAZ JR., Tércio, CARRAZZA, Roque Antonio, NERY JUNIOR, Nelson, Efeito ex nunc $e$ as decisões do STJ. Barueri: Manole, 2008, pp. 75-107.

NEVES, Daniel Amorim Assumpção. Preclusões para o juiz: preclusão pro iudicato $e$ preclusão judicial no processo civil. São Paulo: Método, 2004.

NOGUEIRA, Pedro Henrique Pedrosa. Notas sobre preclusão e venire contra factum proprium. In Revista de Processo, São Paulo, ano 34, n. 168, fev.2009, pp. 331-345.

Situações jurídicas processuais. In DIDIER JR., Fredie (coord.), Teoria do Processo: panorama doutrinário mundial, v. 2. Salvador: Juspodivm, 2010, pp.749-769.

NORONHA, Fernando. $O$ direito dos contratos e seus princípios fundamentais (autonomia privada, boa-fé, justiça contratual). São Paulo: Saraiva, 1994.

NOVELlI, Giovanni; PETITTI, Stefano. Codice di procedura civile annotado con la giurisprudenza. Milano: Giuffrè, 2010. 
OLIVEIRA, Ana Lúcia Iucker Meirelles de. Litigância de má-fé. São Paulo: Editora Revista dos Tribunais, 2000.

OTEIZA, Eduardo. Abuso de los derechos procesales en América Latina. In BARBOSA MOREIRA, José Carlos (coord.), Abuso dos direitos processuais. Rio de Janeiro: Forense, 2000, pp. 7-32.

PALACIO, Lino Enrique. Los deberes de lealtad, probidad y buena fe en el proceso civil. In CÓRDOBA, Marcos M., CORDOBERA, Lidia M. Garrido, KLUGER, Vivian (coords.), Tratado de la Buena Fe em el Derecho. $1^{\mathrm{a}}$ ed, v. 1. Buenos Aires: La Ley, 2004, pp. 813-819.

PASTOR, Carlos Daniel. El abuso procesal. In PEYRANO, Jorge W., RAMBALDO, Juan Alberto (coords.), Abuso procesal. Buenos Aires: Rubinzal-Culzoni, 2006, pp. 57-73.

PENTEADO, Luciano de Camargo. Figuras parcelares da boa-fé objetiva e venire contra factum proprium. In Revista de Direito Privado, São Paulo, ano 7, v. 27, pg 234-278, jul./set.2006.

PEYRANO, Jorge W. La conducta procesal como elemento de convicción favorable a su autor. In PEYRANO, Jorge W. e ACOSTA, Daniel Fernando (coords.), Valoración judicial de la conducta procesal. $1^{\mathrm{a}} \mathrm{ed}$. Santa Fe: Rubinzal-Culzoni, 2005, pp. 17-23.

Otro principio procesal: la proscripción del abuso del derecho en el campo del proceso civil. In PEYRANO, Jorge W., RAMBALDO, Juan Alberto (coords.), Abuso procesal. Buenos Aires: Rubinzal-Culzoni, 2006, pp. 189-197.

La doctrina de los propios actos en el ámbito del procedimiento civil. In PEYRANO, Jorge W. e ACOSTA, Daniel Fernando (coords.), Valoración judicial de la conducta procesal. $1^{\mathrm{a}} \mathrm{ed}$. Santa Fe: Rubinzal-Culzoni, 2005, pp. 221-241.

PEYRANO, Jorge W. e CHIAPPINI, Julio O., La prueba de intercadencia. In El proceso atípico. Buenos Aires: Editorial Universidad, 1984, pp. 77-86.

, Informe sobre la doctrina de los propios actos en el campo procesal. In CHIAPPINI, Julio O., Cuestiones sobre la prueba civil. CPCN. Santa Fe: Jurídica Panamericana, 2006, pp. 677-686.

PEYRANO, Marcos L. La valoración de la conducta procesal de las partes como derivación del principio de adquisión procesal. Su verdadera naturaleza jurídica. In PEYRANO, Jorge W. e ACOSTA, Daniel Fernando (coords.), Valoración judicial de la conducta procesal. $1^{\text {a }}$ ed. Santa Fe: Rubinzal-Culzoni, 2005, pp. 45-55.

PIAGGI, Ana I. Reflexiones sobre dos principios basilares del derecho: La buena fe y los actos proprios. In CÓRDOBA, Marcos M., CORDOBERA, Lidia M. Garrido, KLUGER, Vivian (coords.), Tratado de la Buena Fe em el Derecho. 1ª ed, v. 1. Buenos Aires: La Ley, 2004, pp. 106-129. 
PICÓ I JUNOY, Joan. El principio de la buena fe procesal. $2^{\mathrm{a}}$ ed. Barcelona: J. M Bosch Editor, 2012.

El derecho procesal entre el garantismo y la eficacia: Un debate mal planetado. In Proceso Civil e Ideología: un prefacio, una sentencia, dos cartas y quince ensayos, Valencia, Tirant lo blanch, 2006, pp. 109-127.

PIMENTA, José Marcelo Barreto. O princípio da boa-fé processual e a ineficácia prática da multa por litigância de má-fé. In Ciência Jurídica, Belo Horizonte, v. 157, pp. 466-476, jan./fev. 2011.

PINTO, Carlos Alberto da Mota. Cessão de contrato: contendo parte tratando a matéria conforme o direito brasileiro. São Paulo: Saraiva, 1985.

PINTO, Paulo Mota. Sobre a proibição do comportamento contraditório (venire contra factum proprium) no direito civil. In Revisa Trimestral de Direito Civil - RTDC, Rio de Janeiro, ano 4, v. 16, pg. 135-183, out./dez. 2003.

PISANI, Andrea Proto. Lezioni di diritto prcessuale civile. Napoli: Jovene editore, 2010.

PIUG BRUTAU, Jose. Estudios de derecho comparado: la doctrina de los actos propios. Barcelona: Ariel, 1951.

PRAZERES, Gustavo Cunha. Venire contra factum proprium nulli conceditur e direito processual: a influência da solidariedade social no processo. In Processo e Direito Material. Salvador: Jurispodivm, 2009, pp. 137-168.

PRETEL e PRETEL, Mariana. A boa-fé objetiva e a lealdade no processo civil brasileiro. Porto Alegre: Núria Fabris, 2009.

RAMBALDO, Juan Alberto. La conducta procesal de las partes como medio de prueba. In PEYRANO, Jorge W. e ACOSTA, Daniel Fernando (coords.), Valoración judicial de la conducta procesal. $1^{\text {a }}$ ed. Santa Fe: Rubinzal-Culzoni, 2005, pp. 159-172.

REDENTI, Enrico e VELLANI, Mario. Diritto Processuale Civile, v. I. Milão: Giuffrè Editore, 2000.

RIBEIRO, Darci Guimarães. O sobreprincípio da boa-fé processual como decorrência do comportamento da parte em juízo. In Revista da Ajuris, Porto Alegre, v. 31, n. 95, pp. 7187, 2004.

. Provas atípicas. Porto Alegre: Livraria do Advogado, 1998.

ROCHA, Raquel Heck Mariano da. Preclusão no processo civil. Porto Alegre: Livraria do Advogado, 2011.

RUBIN, Fernando. A preclusão na dinâmica do Processo Civil. 2 ed. São Paulo: Atlas, 2014. 
SANTOS, Leide Maria Gonçalves. Boa-fé objetiva no processo civil: a teoria dos modelos de Miguel Reale aplicada à jurisprudência brasileira contemporânea. Curitiba: Juruá, 2012.

SCHREIBER, Anderson. A proibição de comportamento contraditório: tutela da confiança e venire contra factum proprium. 2 ed. Rio de Janeiro: Renovar, 2007.

SENNA, Andressa Paula. O abuso de direito e a litigância de má-fé como impeditivos à marcha processual e ao resultado justo da prestação jurisdicional. In Revista de Direito Privado, São Paulo, RT, ano 10, n. 40, out./dez. 2009.

SESSAREGO, Carlos Fernández. Abuso del derecho. Buenos Aires: Astrea de Alfredo y Ricardo Depalma, 1992.

SICA, Heitor Vitor Mendonça. Preclusão processual civil. 2aed. São Paulo: Atlas, 2008.

- Contribuição ao estudo da teoria das nulidades: comparação entre o sistema de invalidades no código civil e no direito processual civil. In Impactos processuais do direito civil. São Paulo: Saraiva, 2008, pp. 183-201.

- Questões velhas e novas sobre a inversão do ônus da prova (CDC, art. $6^{o}$, VIII). In Revista de Processo, São Paulo, ano 32, n. 146, abr.2007, pp. 4968.

SOLIMINE, Omar Luis Diaz. La buena fe en la estructura procesal. In CÓRDOBA, Marcos M., CORDOBERA, Lidia M. Garrido, KLUGER, Vivian (coords.), Tratado de la Buena Fe em el Derecho. $1^{\text {a }}$ ed, v. 1. Buenos Aires: La Ley, 2004, pp. 857-886.

SOSA, Angel Landoni. El abuso de los derechos procesales. In BARBOSA MOREIRA, José Carlos (coord.), Abuso dos direitos processuais. Rio de Janeiro: Forense, 2000, pp. 131-151.

SOSA, Gualberto Lucas. Abuso de derechos procesales. In BARBOSA MOREIRA, José Carlos (coord.), Abuso dos direitos processuais. Rio de Janeiro: Forense, 2000, pp. 33-68.

SOUZA, André Pagani de. Vedação das decisões-surpresa no processo civil. São Paulo: Saraiva, 2014.

SOUZA JUNIOR, Sidney Pereira. A preclusão pro iudicato na determinação de provas e a "limitação" do poder instrutório do juiz (art. 130 do CPC) (Comentários ao REsp 345.436-SP). In Revista de processo, ano 33, n. 158, abr./2008, pp.264-278.

STOCO, Rui, Abuso do direito e má-fé processual. São Paulo: Editora Revista dos Tribunais, 2002.

SUDILOVSKY, Carina Paula. Relexiones sobre la valoración judicial de la conducta en juicio. Una propuesta académica. In PEYRANO, Jorge W. e ACOSTA, Daniel Fernando 
(coords.), Valoración judicial de la conducta procesal. 1ªed. Santa Fe: Rubinzal-Culzoni, 2005, pp. 361-370.

TABOSA, Fabio. In MARCATO, Antonio Carlos (coord.). Código de processo civil interpretado, $2^{\mathrm{a}}$ ed. São Paulo: Atlas, 2005.

TARUFFO, Michele. Abuso de direitos processuais: padrões comparativos de lealdade processual (relatório geral). In Revista de Processo, São Paulo, ano 34, n. 177, nov.2009, pp. 153-183.

Poteri probatorio delle parti e del giudice in Europa. In Revista de processo, São Paulo, ano 31, n. 133, mar.2006, pp. 239-266.

Marcial Pons, 2012. Uma simples verdade: o juiz e a construção dos fatos. São Paulo:

TEPSICH, María Belén. Valor vinculante de la conducta procesal de las partes en el proceso civil, in PEYRANO, Jorge W. e ACOSTA, Daniel Fernando (coords.), Valoración judicial de la conducta procesal. $1^{\text {a }}$ ed. Santa Fe: Rubinzal-Culzoni, 2005, pp. 293-311.

THEODORO JÚNIOR, Humberto. Boa-fé e processo: princípios éticos na repressão à litigância de má-fé - Papel do juiz, pp. 636-647. In MARINONI, Luiz Guilherme (coord.), Estudos de Direito Processual Civil: homenagem ao Professor Egas Dirceu Moniz de Aragão. São Paulo: Editora Revista dos Tribunais, 2005.

THEODORO JÚNIOR, Humberto. A preclusão no processo civil. In Revista dos Tribunais, ano 90, vol. 784, fev. 2001, pp. 11-28.

- Abuso de direito processual no ordenamento jurídico brasileiro. In BARBOSA MOREIRA, José Carlos (coord.), Abuso dos direitos processuais. Rio de Janeiro: Forense, 2000, pp. 93-129.

VELLOSO, Adolfo Alvarado. El juez: sus deberes y facultades. Buenos Aires: Depalma, 1982.

ZANELLATO, Marco Antonio. Da boa-fé no direito privado. Dissertação (Mestrado em Direito). Faculdade de Direito, Universidade de São Paulo. São Paulo, 2002.

WAMBIER, Teresa Arruda Alvim. Existe a "discricionariedade" judicial?. In Revista de Processo, São Paulo, ano 18, n. 70, abr./jun.1993, pp. 232-234.

WATANABE, Kazuo. Cognição no Processo Civil. $4^{\mathrm{a}}$ ed. São Paulo: Saraiva, 2012.

WHITE, Inés Lépori. La conducta procesal de las partes y los medios de prueba. In PEYRANO, Jorge W. e ACOSTA, Daniel Fernando (coords.), Valoración judicial de la conducta procesal. $1^{\mathrm{a}} \mathrm{ed}$. Santa Fe: Rubinzal-Culzoni, 2005, pp. 141-157.

WIEACKER, Franz. El principio general de la buena fe. Madrid: Editorial Civitas, 1977. 
YARSHEL, Flávio Luiz. Antecipação da prova sem o requisito da urgência e o direito autônomo à prova. São Paulo: Malheiros, 2009.

ZUCKERMAN, ADRIAN. Civil procedure - principles of practice. 3ed. London: Sweet \& Maxwell, 2013. 